
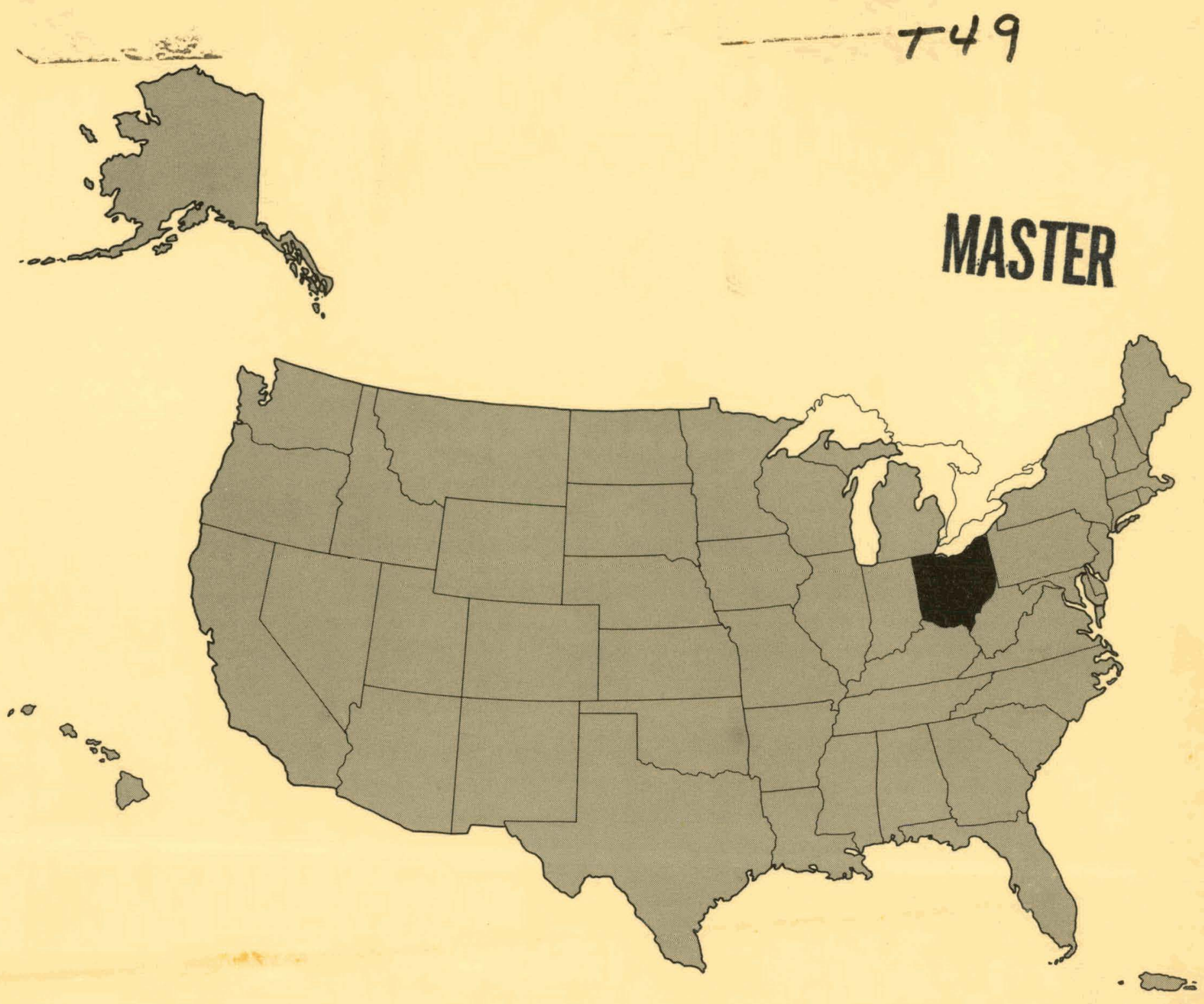

\title{
Ohio State Briefing Book for Low-Level Radioactive - Waste Management
}

MASTER 


\section{DISCLAIMER}

This report was prepared as an account of work sponsored by an agency of the United States Government. Neither the United States Government nor any agency Thereof, nor any of their employees, makes any warranty, express or implied, or assumes any legal liability or responsibility for the accuracy, completeness, or usefulness of any information, apparatus, product, or process disclosed, or represents that its use would not infringe privately owned rights. Reference herein to any specific commercial product, process, or service by trade name, trademark, manufacturer, or otherwise does not necessarily constitute or imply its endorsement, recommendation, or favoring by the United States Government or any agency thereof. The views and opinions of authors expressed herein do not necessarily state or reflect those of the United States Government or any agency thereof. 


\section{DISCLAIMER}

Portions of this document may be illegible in electronic image products. Images are produced from the best available original document. 


$$
\text { DOE/ED/O1570-T4G }
$$

DOE/ID/01570--T49

DE82 015211

\author{
OHIO STATE BRIEFING BOOK \\ LOW-LEVEL RADIOACTIVE WASTE MANAGEMENT
}

Prepared for

EG\&G Idaho, Inc. under

Subcontract No. K-19.34

\title{
Prepared by
}

Synergic Resources Corporation

One Bala-Cynwyd Plaza, Suite 630

Bala Cynwyd, Pennsylvania 19004

April 1981

This book. was preplared as an account of work sponsored by an agency of the United States Government. Neither the United States Government nor any agency inestul. mit ony of their emnlinye.s. makes any warranty, express of implied. Of assumes any legal liebility or ressonsitility tor the accuras.
completeness, or usefunness of any intormation, apparatus. product, or process disclosed. or represents that its use would not infringe privately owned rights Refesence herein to any specific commercial product, process, or service by trade name, tredemark, manulacturee, of otherwise, does

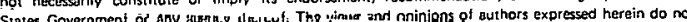
nocessarily state or reflect those of the United States Government of any agency thereot.

This report was prepared as an account of work sponsored by the United States Government. Neither the United States nor the Department of Energy, nor any of their employees, nor any of their contractors, subcontractors, or their employees, makes any warranty, exprees or implied, or assumes any legal liability or responsibility for the accuracy, completeness, or usefulness of any information, apparalus, product, or prosess disclosed, or represents that its use would not infringe privately owned rights.

\section{NOTICE}

PORTIONS OF THIS REPORT ARE TILIECIBTE. I' has been reproduced from the best available copy to permit the broadest possible availability. 
Title Page

contents

ii

List of Figures

List of Tables

vi

\section{Section}

1. Introduction

$1-1$

2. Overview of State Low-Level Radioactive Waste Management Practices

3. Environmental Characteristics

3.1 Environmental Characterization $3-1$

3.1 .1 Location 3-1

3.1.2 Geology 3-1

3.1.3 Hydrology 3-3

3.1 .4 Climate. 3-3

3.2 Population 3-4

3.3 Economy 3-6

3.3.1 Economic Indicators 3-6

3.3.2 Economic Composition 3-8

3.4 Agriculture 3-8

3.5 Energy $3-8$

3.5.1 Energy Consumption : . 3-8

3.6 Electrical Generation and Nuclear Power 3-13

4. Governmental and Public Aspects

4.1 Congressional Representation 4-1

4.2 State Government 4-9.

4.2.1. Constitution . . 4-9

4.2.2 Executive Branch 4-9

4.2.2.1 Governor . . 4-9

4.2.2.2 Departments $\quad 4-10$

4.2.3 Legislative Branch $\quad 4-20$

4.2.3.1 General Features 4-20

4.2.3.2 Powers of the General Assembly 4-20

4.2.3.3 Legislative Procedures 4-21

4.2.3.4 Organization of the Senate 4-21

$\begin{array}{ll}4.2 .3 .5 & \text { Organization of the House of } \\ \text { Representatives } & 4-25\end{array}$

4.2.3.6 Political Parties. 4-33 
4.2.4 Judicial Branch

4-33

4.2.5 Local Government

5. A Review of State. Low-Level Waste Management Policy: Present and Proposed.

$5-1$

5.1 Overview 5-1

5.2 Existing Nuclear Waste Management Policy in Ohio 5-1

5.2.1. Ohio Revised Code, Chapter 107.14 5-1

5.2.2 Ohio Revised Code, Chapter 122 5-1

5.2.3 Ohio Revised Code, Chapter 3701.33-.34 5-3

5.2 .4 Ohio Revised Code, Chapter 3701.4. 5-3

5.2.5 Ohio Revised Code, Chapter 4163 5-4

5.2.6 Ohio Revised Code, Chapter 6121 5-5

5.2.7 Ohio Revised Code, Chapter $6123 \quad 5-6$

5.2.8 Ohio Administrative Code, Radiation
Protection Rules

5.2.9 State of Ohio, Memorandum of Understanding 5-7

5.2.10 Amended Senate Bill No.208. 5-7

5.2.11 Amended House Joint Resolution 27 5-7

5.2.12 Low-Level Radioactive Waste Management in Ohio:

Summary of Legislative and Administrative Mandates

$5-8$

6. Interest Groups

$6-1$

6.1 Introduction

6-1

6.2 Listing of Relevant Interest Groups $6-2$

6.2.1 List of kinvironmental Groups 6-2

6.2.2 Medical/Research Interest Groups : 6-3

6.2.3 Public Interest Groups 6-3

6.2 .4 Labor Groups 6-3

7: Mass Media . 7-1

7.1 Introduction 7-1

7.2 Media Coverage 7-1

7.2 .1 Overview 7-1

7.2.2 Volume of Coverage 7-2

7.2.3 Issues Raised 7-3

7.3 Specific Media Coverage $7-3$

7.3.1 Cleveland 7-3

7.3.2 Columbus 7-4

7.3.3 Cincinnati 7-4

7.4 Conclusions $7-5$

8. Survey Methodology 8-1 
9. A Profile of Low-Level Radioactive Waste Generation and Disposal

9-1

$9-1$

$9-4$

9.2 Sources of Shipped Wastes

9.2.1 Distribution By Type of Facilities Shipping Wastes

9.2.2 Origin of Radioactivity Resulting in Shipped Wastes

9.3 Volume of Shipped Waste

$9-6$

9.4 Activity of Shipped Waste

9-9

9.5 Physical Characteristics of shipped wastes

\section{Appendices}
A. A listing of Radioactive Licenses in the State of Ohio
B. Ohio Legislations and Regulations
C. Media Reference Material 
3-1 Ohio County Map

$3-2$

3-2 Standard Metropolitan Statistical Areas (SMSA's) Map of Ohio

3-5

$3-3$

Consumption of Energy By Fuel Type - Ohio

3-14

$3-4$

Consumption of Energy By Sector

$3-15$

3-5

Net Energy Demand of All Ohio Electric Utilities

3-18

3-6

Generation Fuel Mix of Power Plants In Ohio

3-19

4-1

Ohio Congressional Districts

4-2

4-2

Ohio State Agencies

4-13

4-3

Ohio Senate Districts

4-22

4-4

Ohio House of Representative Districts

4-26

8-1

Low-Ievel Radioactive Waste Survey

8-2

$8-2$

Survey Letter of Transmittal

$8-6$ 
2-1 Use of Commercial Low-Level Waste Facilities. 2-2

2-2 Disposal Practices Used For Low-Ievel Wastes 2-5

2-3 Sources of Radioactivity Requiring Disposal 2-6

3-1 Ohio Population Data And Projections 3-7

3-2 Ohio Employment Rate 3-9

3-3 Total Personal Income 3-9

3-4 Ohio Gross State Product 3-10

3-5 Gross state Product By Industry sector 3-11

3-6 Ohio Farm Production 3-12

3-7 Ohio Energy Consumption By Sector 3-16

3-8 Projected Demand By Electric Regions Serving Obio 3-17

3-9 Overview of Nuclear Plants In Ohio:

Present And Projected 3-20

4-1 Ohio Members of The United States Congress 4-4

4-2 Votes of Ohio Congressmen On Recent Relevant Legislation 4-7

4-3 Ohio State Senators 4-23

4-4 Ohio State Representatives. 4-27

9-1 Use of Commercial Low-Level Waste Facilities 9-2

9-2 Analysis of Overall Survey: Response 9-3

9-3 Type of Facilities Shipping Low-Level Waste 9-5

9-4 Origin of Radioactivity Resulting In Shipped Waste 9-7

9-5 Volume of Waste Shipped 9 9-8

9-6 Estimated Generation (Cu. Ft.) 9-10

9-7 Activity of Shipped Waste 9-11

9-8 Radionuclides In Shipped Waste - Medical 9-13

9-9 Radionuclides In Shipped Waste - Educational 9-14

9-10 Radionuclides In Shipped Waste - Industrial 9-15

9-11 Radionuclides In Shipped Waste - Power Reactor 9-16.

9-12 Radionuclides In Shipped Waste - Governmental 9-17

9-13 Radionuclides In Shipped Waste - Total 9-18

9-14 Onsite Processing of Waste 9-19

9-15 Shipping Container Used ' · 9-20

9-16 Physical Form of Shipped Waste 9-21 


\section{INTRODUCTION}

The Ohio State Briefing Book for low-level radioactive waste management has been prepared to assist in the planning and formulation of an implementation strategy leading to the creation of a suitable low-level radioactive waste management program in the United States. The Ohio Briefing Book is one of a series of briefing books now being prepared that will provide coverage on waste management practices in the States, along with relevant demographic, government, and media information.

Low-level radioactive waste management is increasingly becoming a major concern in the United States. Low-level radioactive waste may contain less than 10 nanocuries of transuranic contaminants per gram of material or only be suspected of radioactive contamination. 1 These wastes are disposed of according to the type and/or concentration of radioactivity. Low-level radioactive waste may consist of a solid, liquid or gas. A significant amount of solid low-level waste that is buried consists of dry waste materials with low levels of radioactivity. Examples of these wastes are papel tiash, pack1ng máterial, protective clothing, broken glassware, plastic sheeting and tubing, defective or obsolete equipment, building rubble, etc.

The low-level radioactive waste that has been disposed of at burial sites has generally come from several different sources: institutional and industrial ( 41 percent); commercial power reactors (50 percent); and government/military wastes (nine percent).2 Forty-nine of 50 states and the District of Columbia generate both institutional and industrial waste, 24 States generate commercial power reactor waste, and 14 States generate government waste.

Part of the reason for producing this report is to obtain more accurate information on the volume of low-level radioactive waste shipped, the sources of the waste (e.g., nuclear reactor, sealed or unsealed sources, etc.), the physical form of the waste, the disposal method (e.g., release 
to sewer, ship to commercial repository, burn on site, etc.) and the type of processing of the waste (e.g., absorption, mechanical compaction, solidification, etc.).

The need to develop a program that is able to effectively manage the low-level waste in the nation is due to the fact that as medical, engineering and other disciplines use more nuclear materials for health care, academic and industrial research and for energy production, the volume of low-level waste has, and will continue to increase. To date, there are only three sites in the United States that accept low-level waste for burial. Two of these three sites have been closed intermittently because of the concern over packaging and shipping operations. The Governors of Washington State, Nevada, and South Carolina, where such commercial lowlevel radioactive waste facilities are located, are extremely concerned about the volume and packaging used in the disposal of waste.

When the Governors of Washington and Nevada took action in 1979 to temporarily close the commercial low-level radioactive waste burial sites located in their respective States, the action shocked many of the waste generators as well as many of the States in which large amounts of low-level waste are generated. Preliminary projections of total national low-level waste generation and capacity of existing commercial disposal facilities indicate that if no changes in current practices or trends occur, the current disposal sites could be filled by the mid-1990s.3 This capacity could also be suddenly reduced if the Governors of the States where waste disposal facilities are located decide to further restrict the volumes accepted for disposal.

Limitations were imposed on the yearly burial quantities to be accepted by the Barnwell disposal site in South Carolina in October of 1979. Washington State passed an initiative in November of 1980 that will restrict the Richland site to in-State or medical waste by July of 1981. These actions will further reduce the availability of burial space. Another concern is the current escalation of costs for transporting and disposing 
each drum of low-level waste. Price escalation is increasing the costs for utilities, medical institutions, and industrial facilities using nuclear materials that require commercial disposal.

These concerns have led the U.S. Department of Energy, as the lead agency for formulating a low-level waste management plan, to embark upon a cooperative effort involving the National Governors' Association (NGA), the National Conference of State Legislatures (NCSL) and other interest groups to formulate an approach for a low-level radioactive waste management program.

Section 2.0 of this briefing book presents an overview of past and present low-level radioactive waste management practices in Ohio. Section 3.0 identifies relevant topography, demography, and energy trends that may affect the quantity and nature of low-level radioactive wastes within the State. An overview of the government and politics of the State is presented in Section 4.0. Section 5.0 reviews present and proposed low-level radioactive waste management policy. Policies affecting the generation, handling and disposal of radioactive waste are reviewed. A review of interest group concerns vis a vis low-level waste management is presented in Section 6.0. A review of public offlcial views and media concerns is presented in Section 7.0. Comparisons are made of mass media coverage of low-level radioactive waste concerns. The survey methodology used to gather information on the volume, method of disposal, physical form and other relevant information pertaining to the shipment of low-level waste is presented in Section 8.0. Finally, the results of the low-level waste generator survey are presented in Section 9.0 . 


\section{REFERENCES}

1. U.S. Department of Energy, Interagency Review Group Final Report, p. 106.

2. N.U.S. Corporation, The 1979 State-by-State Assessment of Low-level Radioactive Wastes Shipped to Commercial Burial Grounds, 1979.

3. National Governors' Association, Task Force on Low-level Radioactive Waste Disposal, Final Report, (August, 1980). 
2. OVERVIEW OF STATE LOW-LEVEL RADIOACTIVE WASTE MANAGEMENT PRACTICES

There are 757 radioactive material licenses in Ohio. There also exist two Formerly Utilized Sites Remedial Action Program (FUSRAP) sites: Clecon Metals and Harshaw Chemical Company. Clecon Metals was formerly owned in the 1940's and 1950's by Horizons' Incorporated and produced granular. thorium metal. Sixty workers are employed there. Harshaw Chemical Company produced UF 4 and yellow cake during 1943. Present radiation levels are believed to be close to background levels.

Of the current number of NRC licensees in Ohio, 171 have two or more licenses. Nuclear power plants are excluded from these 586 separate license holders. Currently, there are two power reactors in Ohio bringing the total number of potential low-level waste generators to 588 .

Information on the disposal practices of the 588 separate license holders was solicited from the survey presented in Section 8.0 of this report. Appendix A presents the name and address of each license holder, the type of contact made to obtain information, the degree of response to the questionnaire, the type of facility, and whether waste is shipped to a commercial disposal site.

The type of facility was classified as either medical, educational, industrial power reactor, or governmental, according to Part I of the survey. It should also be noted that the medical classification includes medical education facilities, and that the governmental classification excludes both medical and educational facilities.

of the 588 potential radioactive waste generators, contact was made with 287 , of which 45 indicated that they ship waste to commercial disposal. facilities. Table 2-1 presents a breakdown of license holders by priority category, type of facility, responses to the questionnaire (telephone, postcard or written), and the number of facilities using commercial disposal 
IABLE 2-1. USE OF COMMEFCIAL LOW-LEVEL WASTE FACILITIES

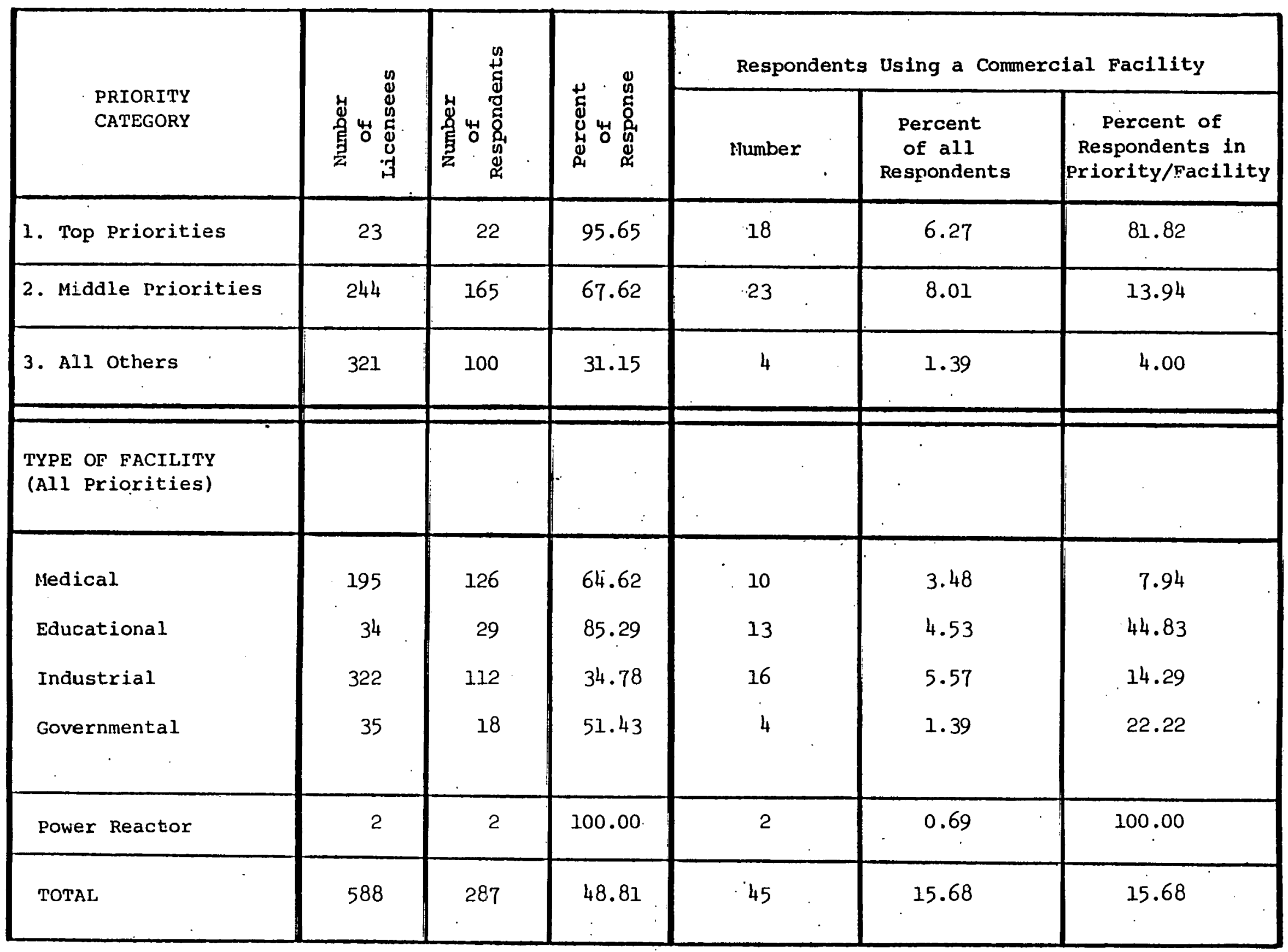


facilities. The "percent of all respondents" was calculated as the number of respondents shipping waste divided by the total number of respondents times 100. The percent of facility respondents was calculated as the number of respondents shipping waste divided by the total number of respondents in a facility classification times 100.

When looking at the response rate by priority category, surveys were obtained from 96 percent of the "top priority" grouping, 68 percent from the "middle priority", and 31 percent from the "other" category. As expected, a much higher percentage of "top priority" respondents reported using commercial disposal facilities (82 percent), in contrast to "others", where only four percent reported using commercial disposal facilities. Educational-type license holders reported the largest percentage utilization of commercial disposal facilities ( 44.8 percent). The largest number of facility types reporting the use of commercial waste disposal facilities is industry $(\mathrm{N}=16)$. Overall, 16 percent of the respondents reported using commercial disposal facilities.

The priority categories listed in the table are based on consultation with NRC regional offices near Chicago, Illinois, and in King of Prussia, Pennsylvania, regarding the NRC category and priority codes that are expected to include generators of significant volumes of low-level radioactive waste. The following categories of licensees are expected to be major generators of low-level radioactive waste:

- I-B Processors/Distributors.

- III-F1A Academic, Type A, Broad.

- III-G1 Medical, Broad License.

- IV-41E Industrial. 
- IV-EIA Industrial, Type A, Broad.

- IV-A6 Medical.

- VI-F Academic.

These categories were stratified into "top" and "middle" priorities, the top priorities being I-B, III-F1A, III-G1, and IV-E1A. Nuclear reactors were also added to the top priority. The second priority consists of VI-F, IV-6, and IV-E. The "all others" category inoludes the remaining NRC licensees surveyed.

Table 9-2 further disaggregates the survey data by showing the type of survey responses (written, telephone, or postcard) received from the licensees.

Table 2-2 presents the waste disposal practices employed, including disposal method other than shipment to commercial disposal facilities. In this table, the total of "number using" exceeds the total number of respondents due to the use of several disposal practices by some facilities.

Over 50 percent of the medical institutions reported combining lowlevel radioactive waste with common refuse, after it decayed to background levels. Close to 20 percent of the medical institutions reported venting the waste to the atmosphere. Almost three out of four educational facilities reported releasing low-level radioactive waste to the sewer. A third of total respondents reported returning radioactive material to the vendor, which is the most common method of low-level waste disposal of the respondents.

Table 2-3 provides data on the sources of radioactivity requiring disposal. The data show that 73 percent of the sources of radioactivity are 
TABLE 2-2. 'DISPOSAL PRACTICES LSED FOR LOW-LEVEL WASTES

\begin{tabular}{|c|c|c|c|c|c|c|c|c|c|c|c|c|c|c|c|}
\hline \multirow{2}{*}{$\begin{array}{l}\text { Type of } \\
\text { Facility } \\
\end{array}$} & \multirow{2}{*}{$\begin{array}{r}\text { Number or } \\
\text { Respondents } \\
\end{array}$} & \multicolumn{2}{|c|}{$\begin{array}{l}\text { Shlp To } \\
\text { Commercial } \\
\text { Repository }\end{array}$} & \multicolumn{2}{|c|}{$\begin{array}{c}\begin{array}{c}\text { Belease To } \\
\text { 8ever }\end{array} \\
\end{array}$} & \multicolumn{2}{|c|}{$\begin{array}{c}\text { Combine W1th } \\
\text { Rerise }\end{array}$} & \multicolumn{2}{|c|}{$\begin{array}{c}\text { Vent To } \\
\text { Atmosphere }\end{array}$} & \multicolumn{2}{|c|}{$\begin{array}{c}\text { Return To } \\
\text { Vendor }\end{array}$} & \multicolumn{2}{|c|}{$\begin{array}{l}\text { Diatribute } \\
\text { In Product }\end{array}$} & \multicolumn{2}{|c|}{$\begin{array}{l}\text { Ho Naste } \\
\text { Ceneratcd }\end{array}$} \\
\hline & & Iunber & Percent & Aumber & Percent & Autber & Fercent & Number & Percent & Kumber & Percent & Uumber & Percent & Number & Fercent \\
\hline Medical & 195 & 20 & 5.1 & 60 & 30.8 & 99 & 50.8 & 38 & 19.5 & 75 & 38.5 & 2 & 1.0 & 32 & 16.4 \\
\hline Educat tonal & 34 & 13 & 38.2 & 25 & 73.5 & 6 & 17.6 & 2 & 5.9 & 4 & 11.8 & 0 & 0.0 & 10 & 29.4 \\
\hline Industrial & 322 & . 16 & 5.0 & 19 & 5.9 & 6 & 1.9 & 16 & 5.0 & 109 & 33.9 & 29 & 5.9 & 49 & 15.2 \\
\hline Power Reactor & $?$ & 2 & 100.0 & 0 & 0.0 & 0 & 0.0 & 1 & 50.0 & 0 & 0.0 & 0 & 0.0 & 0 & 0.0 \\
\hline Government & 35 & 4 & 11.4 & 2 & 5.7 & 0 & 0.0 & 1 & 2.9 & 5 & 24.3 & 0 & 0.0 & 10 & 28.6 \\
\hline TOTAL & 588 & 45. & 7.7 & 106 & 18.0 & 111 & 18.9 & 58 & 9.9 & 193 & 32.8 & 28 & 4.8 & 101 & 27.2 \\
\hline
\end{tabular}


TABLE 2-3. SOURCES OF RADIOACTIVITY REQUIRING DISPOSAL

\begin{tabular}{|c|c|c|c|c|c|c|c|}
\hline \multirow{2}{*}{$\begin{array}{l}\text { Type of } \\
\text { Facility }\end{array}$} & \multirow{2}{*}{$\begin{array}{r}\text { Number of } \\
\text { Responjents } \\
\end{array}$} & \multicolumn{2}{|c|}{ Nuclear Reactor } & \multicolumn{2}{|c|}{ Sealed Sources } & \multicolumn{2}{|c|}{$\begin{array}{c}\text { Unsealed Radioactive } \\
\text { Material } \\
\end{array}$} \\
\hline & & Number & Percent & Number & Percent & Number & Percent \\
\hline Medical & 163 & 0 & 0.0 & 120 & 73.6 & 84 & 51.5 \\
\hline Educa-ional & 24 & 2 & 8.3 & 12 & 50.0 & 18 & 75.0 \\
\hline Industrial & 273 & 10 & 3.7 & 214 & 78.4 & 14 & 5.1 \\
\hline Power Reactor & 2 & 2 & 100.0 & 0 & 0.0 & 0 & 0.0 \\
\hline Governmental & 25 & 1 & 4.0 & 10 & 40.0 & 4 & 16.0 \\
\hline TOTAL & 487 & 15 & 3.1 & 356 & 73.1 & 120 & 24.6 \\
\hline
\end{tabular}


sealed sources. Close to 25 percent of the radioactive material used is unsealed.

Hospital authorities contacted as part of the telephone survey stated that all hospitals using unsealed material were required by law to have sealed calibration sources as well. Thus, though not reported as such, the number of sealed source responses should be greater than or equal to the number of unsealed material responses. 


\section{ENVIRONMENTAL CHARACTERISTICS}

This section provides a description of the physical and economic parameters which impact low-level radioactive waste generation and disposal. Information is reviewed concerning the State's geology, hydrology and climate. Data describing the composition, growth and distribution of economic activity are also presented. Finally, an energy profile of the State is provided, including electrical generation activity and the present and future utilization of nuclear power.

\subsection{Environmental Characterization}

\subsubsection{Location}

Ohio is located in the East North Central U.S. Census region. Ohio is bordered on the north by Lake Erie, to the east by Pennsylvania, separated from West Virginia to the southeast and Kentucky to the south by the Ohio River, and shares its western border with Indiana (See Figure 3-1).

\section{1 .2 Geology}

The topography, river systems and groundwater, and soils in most of Ohio are the product of past glacial activity. Three-fourths of Ohio's surface is glaciated, with the glacial line extending from Pennsylvania west to Holmes County and irregularly south to Brown County. Great ice sheets rounded off hills and filled valleys with fertile soil.

Ohio's rolling plains are divided into three physiographic regions: the Allegheny Plateau, the Lake Plains, and the Central Plains. The Allegheny Plateau reaches westward from Pennsylvania and West Virginia into Ohio's eastern counties from Lake Erie to the Ohio River. Throughout the plateau, rivers wind among steep hills and many elevations reach 1400 feet. 


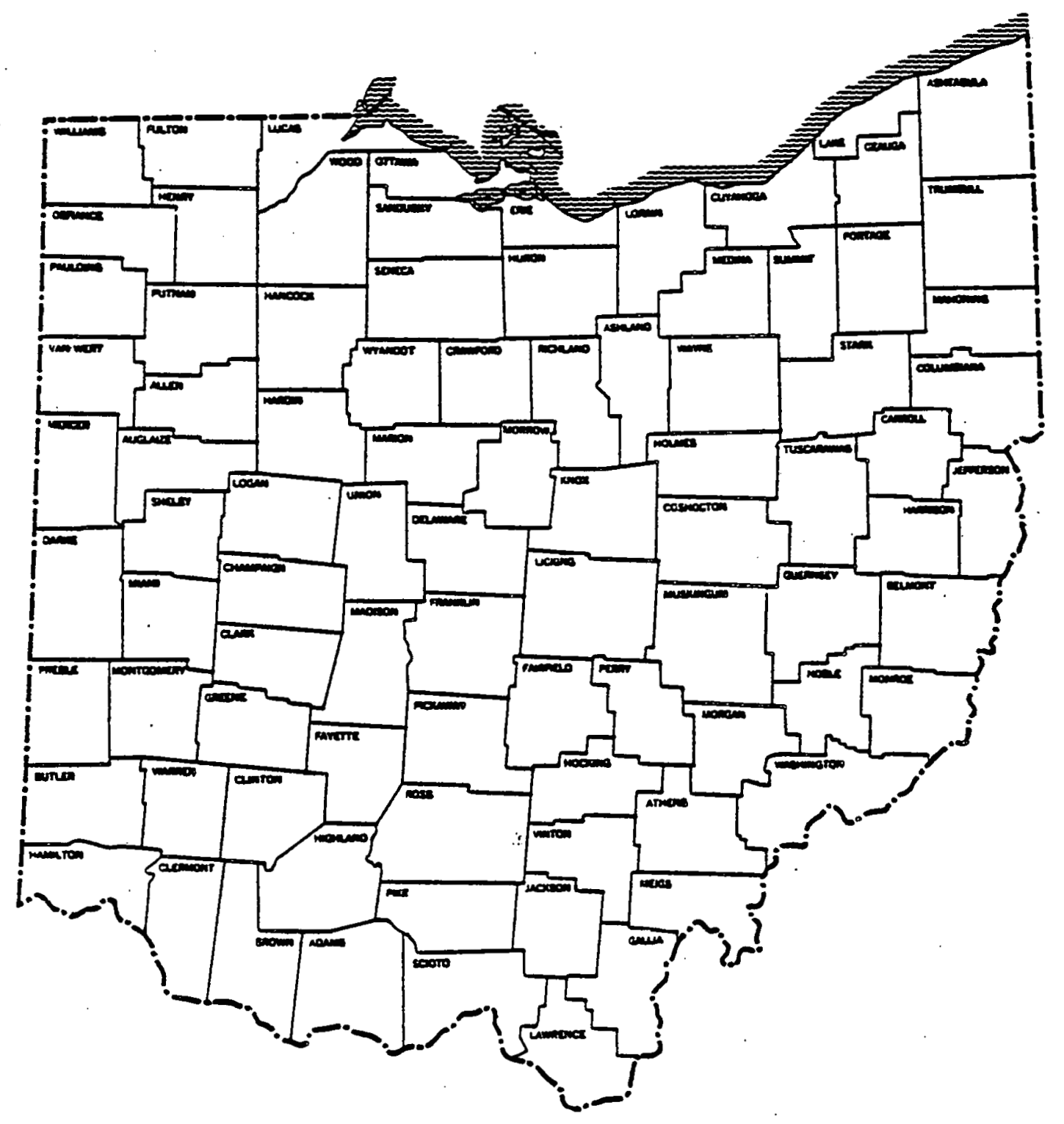

Figure 3-1. Ohio county map Source: American Map Company 
The Lake Plains stretch along Lake Erie to the northwestern counties and the Michigan boundary, then irregularly to the south. These low rolling plains, once under the waters of Lake Erie, constituted the Black Swamp area. When the swamps were drained, excellent agricultural land was exposed.

The Central Plains, extending westward beyond the Mississippi, provide deep and fertile soil for western and southwestern Ohio. Within this region, the State's highest and lowest points are located.

\section{1 .3 Hydrology}

The principal water sources of Ohio are the rain fed streams, lakes. and reservoirs. A low watershed separates Ohio's two drainage basins. The Maumee, Sandusky, Cuyahoga and Grand Rivers draining into Lake Erie account for 30 percent of the surface drainage, while the Miami, Little Miami, Scioto, Hocking, Muskingum and Mahoning Rivers draining into the Ohio River account for 70 percent. Lake Erie, with its 230 miles of Ohio shoreline, has an average depth of only 62 feet. Its shallowness, coupled with the concentration of population and industrial plants in its watersheds, have led to a serious pollution problem.

The State contains 110 lakes of which 27, lying chiefly in the northeast, are natural. Eighty-three lakes have been built for industrlal, flood control, recreational and other purposes.

of the 16.8 billion gallons of water consumed daily statewide in 1978 , groundwater constitutes 1.3 billion gallons a day ( 7.5 percent). All major urban areas depend upon surface water supplies. Although Ohio is situated over numerous aquifers, the abundance of surface water has precluded large scale development of groundwater resources.

\subsubsection{Climate}

Ohio has a moderate climate. Annual precipitation averages about 37 inches, with the southern portions of the State receiving slightly higher 
amounts. Precipitation is also higher in the southern locations, due to the influence of wind direction during the summer, which through its clockwise flow carries moist air up from the Gulf of Mexico. Snowfall is higher near Lake Erie due to snow squalls generated by the frequent northwest winter winds. Severe weather usually occurs in spring or summer as thunderstorms and occasional tornadoes occur (Ohio averages about 12 tornadoes per year).

\subsection{Population}

Ohio, like many of the Northeastern industrial States, had experienced steady population growth from the end of the depression until the 1970 Census. Ohio's population increased from 6.9 million to almost 10.7 million during this period, equal to an annual growth rate of 1.45 percent. During the same time span the nation's population growth rate was 1.44 percent. 1

The 1970's saw an abrupt change in the pattern of national growth. While the Pacific and Mountain States have been growing fastep than the national average since World War II, during the decade of the 1970's the Sunbelt States grew most rapidly. According to the 1980 Census, Ohio is the sixth most populous State. During the decade of the 1970's Ohio's population growth rate was only 0.13 percent, well below the national rate of 1.09 percent. A declining birth rate and increased out-migration were responsible for Ohio's relative decline. 2

There are 14 Standard Metropolitan Statistical Areas (SMSA) in Ohio (Figure 3-2). Excluding three counties which are part of SMSA's centered in adjacent States (Belmont, Washington and Lawrence counties), 76.8 percent of the State's population is presently located in these urban centers, down from 79.1 percent in 1970. There are three SMSA's containing more than a million people: Cleveland, Columbus and Cincinnati. Other large SMSA's include Akron, Dayton and Toledo with each exceeding 700,000 in population. 3 


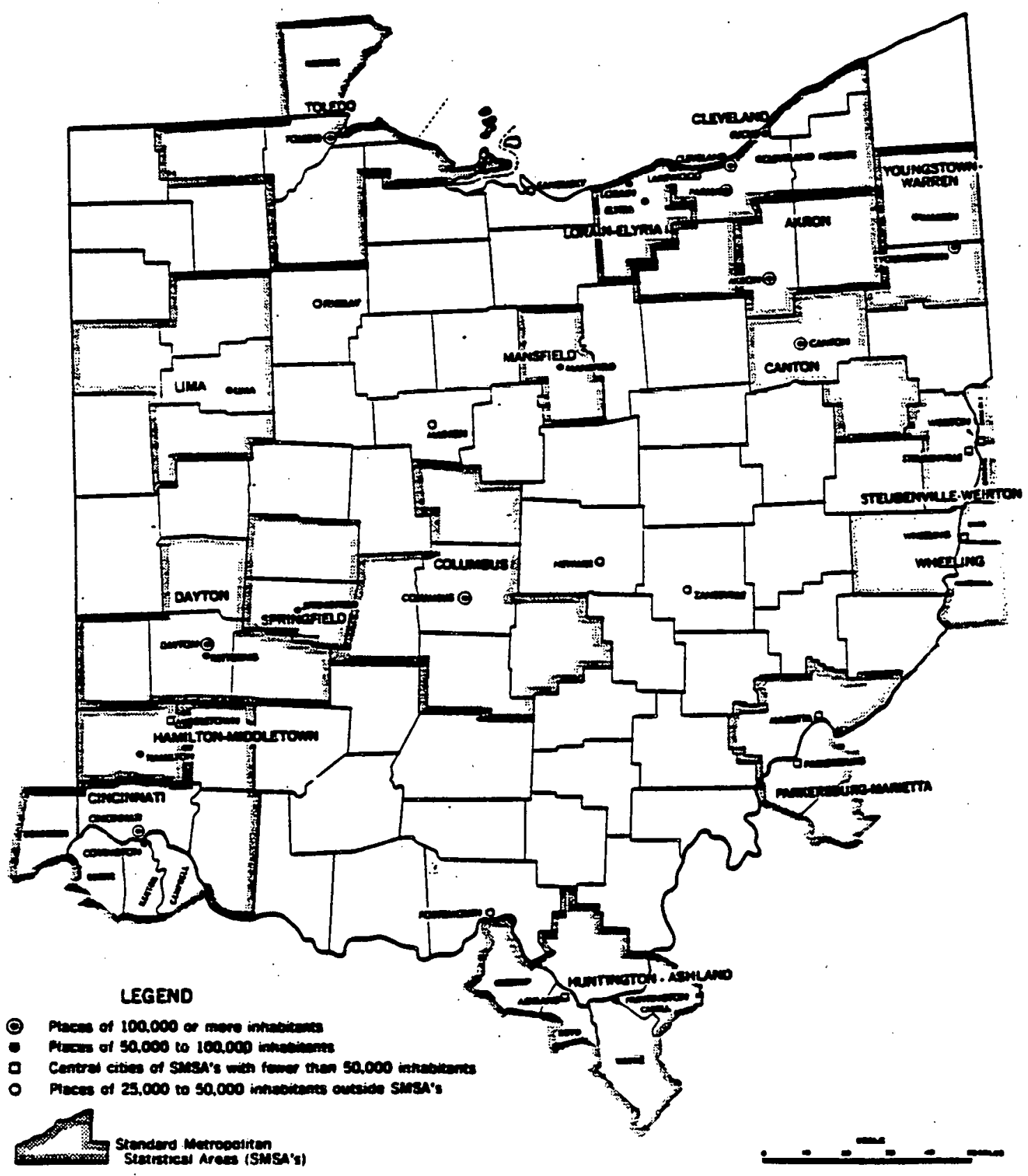

Figure 3-2. Standard Metronolitan Statistical Areas (SMSA's) map of ohio.

Source: U.S. Dept. of Commerce, Census of Manufactures,

Geographic Area Survey 
Table 3-1 gives the population of Ohio SMSA's and projections for the year 2000. The population of urban areas actually declined during the last decade, led by Cleveland with a decrease of 170,559 people, followed by Dayton $(26,799)$, Akron $(19,261)$ and Cincinnati $(15,640)$. The largest increase among SMSA's was recorded in Columbus $(67,185)$, followed by Hamilton-Middleton $(32,173)$. However it was in the rural counties that the largest increase in the State was recorded; an increase of 274,394 was recorded by the Census.

Population projections prepared by the State estimate population for the year 2000 to reach 12,019,000. This would require a substantial increase in Ohio's growth rate during a period when the Bureau of Economic Analysis (BEA) expects the national growth rate to decline to 0.8 percent. The BEA projection for Ohio, when adjusted for the 1980 Census would result in a year 2000 population of $11,592,000$, with an annual growth rate of 0.4 percent. The growth rate of the last decade if continued for the rest of the century would result in a population of $11,082,000.4$

\subsection{Econnmy}

\subsubsection{Economic Indicators}

Ohio's economy is centered around manufacturing, which in turn is highly dependent upon the automobile. Therefore the State tends to follow the automobile industry's peaks and valleys. As Table 3-2 demonstrates, the Ohio unemployment rate exceeded the national average during the oil embargo induced recession of 1974-75 and dropped below the national average during the recovery period. For December 1980, the Ohio Bureau of Employment Service reported that the unemployment rate for the State was 8.5 percent versus a national average of 6.9 percent. 5 
TABLE 3-1. OHIO POPULIATION DATA AND PROJECTIONS

\begin{tabular}{|c|c|c|c|c|c|}
\hline \multirow[b]{2}{*}{ Reg1on } & \multicolumn{3}{|c|}{ Population } & \multicolumn{2}{|c|}{ Annual Growth Rate } \\
\hline & $1970^{\circ}$ & 1980 & 2000 & $\begin{array}{c}1970-1980 \\
\& \\
\end{array}$ & $\begin{array}{c}1980-2000 \\
\\
\end{array}$ \\
\hline United States & $203,211,926$ & $226,504,825$ & $265,637,000$ & 1.09 & 0.80 \\
\hline Onto & $10,657,423$ & $10,797,419$ & $12,019,000$ & 0.13 & 0.54 \\
\hline SMSA : & $8,431,493$ & $8,297,095$ & $9,362,900$ & -0.16 & 0.61 \\
\hline $\begin{array}{l}\text { Akron } \\
\text { Canton } \\
\text { Cincinnati } \\
\text { Cleveland } \\
\text { Columbus } \\
\text { Dayton } \\
\text { Hamilton-Middleton } \\
\text { Lima } \\
\text { Lorain-Elyria } \\
\text { Mansfield } \\
\text { Springfleld } \\
\text { Toledo } \\
\text { Youngstown-Warren } \\
\text { Steubenville }\end{array}$ & $\begin{array}{r}679,239 \\
393,789 \\
1,106,821 \\
2,063,729 \\
1,017,847 \\
852,531 \\
226,207 \\
210,074 \\
256,843 \\
129,997 \\
187,606 \\
643,493 \\
537,124 \\
96,193\end{array}$ & $\begin{array}{r}659,978 \\
402,979 \\
1,091,181 \\
1,893,170 \\
1,085,032 \\
825,732 \\
258,380 \\
217,756 \\
273,983 \\
131,310 \\
183,042 \\
656,344 \\
527,734 \\
90,474\end{array}$ & $\begin{array}{r}735,100 \\
459,400 \\
1,176,200 \\
2,046,200 \\
1,367,800 \\
950,900 \\
310,200 \\
231,100 \\
328,600 \\
145,000 \\
209,600 \\
736,200 \\
580,600 \\
86,000\end{array}$ & $\begin{array}{r}-0.29 \\
0.23 \\
-0.14 \\
-0.87 \\
0.64 \\
-0.32 \\
1.34 \\
0.36 \\
0.65 \\
0.10 \\
-0.25 \\
0.20 \\
-0.18 \\
-0.61\end{array}$ & $\begin{array}{l}0.54 \\
0.66 \\
0.38 \\
0.39 \\
1.16 \\
0.71 \\
0.92 \\
0.30 \\
0.91 \\
0.50 \\
0.68 \\
0.58 \\
0.48 \\
-0.25\end{array}$ \\
\hline Remainder of state & $2,225,930$ & $2,500,324$ & $2,656,100$ & 1.17 & 0.30 \\
\hline
\end{tabular}

Source: Ohio Department of Economic and Community Development, Office of Research, Population Projections by County, 1980-2000 
Other indicators such as total personal income (Table 3-3) and gross State product (Table 3-4) show a steady decline relative to the national economy. Ohio per capita income has also declined relative to the country as a whole, but Bureau of Economic Analysis projections expect personal per capita income to increase on a relative basis by the end of the century. 6

\subsubsection{Economic Composition}

The dominant industry sectors of Ohio are manufacturing, trade, F.I.R.E. (finance, insurance and real estate), services and transportation, communications and utilities. All these sectors have been growing at an annual rate exceeding three percent for the last two decades (see Table 3-5). The sectors that will grow fastest during the next two decades, according to BEA projections, will be mining and services. 7

\subsection{Agriculture}

Ohio is ranked 13 in the country in the farm value of agricultural products. Table 3-6 provides the quantity, value and rank of various crops, livestock and poultry in Ohio. The farm value of all agricultural products was about four billion dollars in 1979. Corn and soybeans were the most important field crops, while milk, cattle and calves, and hogs and pigs were the major livestock products. 8

\subsection{Energy}

\subsubsection{Energy Consumption}

Energy consumption in Ohio increased steadily from 1960 to 1973, when the oil embargo and subsequent increases in energy prices changed consumption patterns. The annual growth rate of energy consumption was 2.8 percent until the embargo, but only 0.07 percent from 1974-1978. The fuel mix consumed by Ohio is still dominated by coal, petroleum and natural gas in that order, though their relative positions have shifted during the last two decades. 
TABLE 3-2. OHIO UNEMPLOYMENT RATE

(Percent)

\begin{tabular}{lcccccc}
\hline & 1970 & 1975 & 1976 & 1977 & $\frac{1978}{6.0}$ & $\frac{1979}{3.0}$ \\
United States & 4.9 & 8.5 & 7.7 & 7.0 & 6.0 & 5.8 \\
Ohio & 5.3 & 9.1 & 7.8 & 6.5 & 5.4 & 5.9 \\
Onto Metropolitan & 5.2 & 8.9 & 7.8 & 6.5 & 5.3 & 5.8 \\
Onio Rural & 5.9 & 10.3 & 8.3 & 6.9 & 5.8 & 6.5 \\
\hline
\end{tabular}

Source: U. S. Department of Commerce, Statistical Abstract of the United States, 1979.

TABLE 3-3. TOTAL PERSONAL INCOME

(Millions of 1980 Dollars)

\begin{tabular}{lrrrrrr}
\hline & \multicolumn{1}{c}{1960} & & 1969 & 1978 & \multicolumn{1}{c}{1990} & \multicolumn{1}{c}{2000} \\
\cline { 2 - 2 } \cline { 5 - 6 } United States & 999,844 & $1,509,833$ & $2,062,937$ & $3,207,633$ & $4,229,798$ \\
Oh10 & 57,015 & 81,613 & 101,910 & 84,127 & 193,132 \\
$\begin{array}{l}\text { Oh10 as Percent } \\
\text { of United Statas }\end{array}$ & 5.70 & 5.41 & 4.94 & 4.75 & 4.57 \\
\hline
\end{tabular}

Source: U. S. Department of Commerce, Bureau of Economic Analysis, State Projections of Personal Income to the year 2000 
TABLE 3-4. OHIO GROSS STATE PRODUCT

(Billions of 1980 Dollars)

\begin{tabular}{|c|c|c|c|c|c|c|}
\hline & 1960 & 1965 & 1970 & 1975 & 1978 & $\begin{array}{c}\text { Hate of Growth } \\
1960-1978 \\
\end{array}$ \\
\hline Ohio GSP & 73.1 & 90.1 & 101.7 & 106.4 & 123.3 & 2.948 \\
\hline U.S. GNP & $1,333.6$ & $1,675.9$ & $1,946.3$ & $2,176.2$ & $2,532.6$ & 3.638 \\
\hline $\begin{array}{l}\text { GSP as a Percent } \\
\text { of GNP }\end{array}$ & 5.488 & 5.388 & 5.238 & 4.898 & 4.878 & - \\
\hline
\end{tabular}

Source: Ohio Department of Economic end Community Development, Office of Research, Comparison of Ohio Gross State Product With Gross National Product 
TABLE 3-5. GROSS STATE PRODUCT BY INDUSTRY SECTOR (Millions of 1980 Dollars)

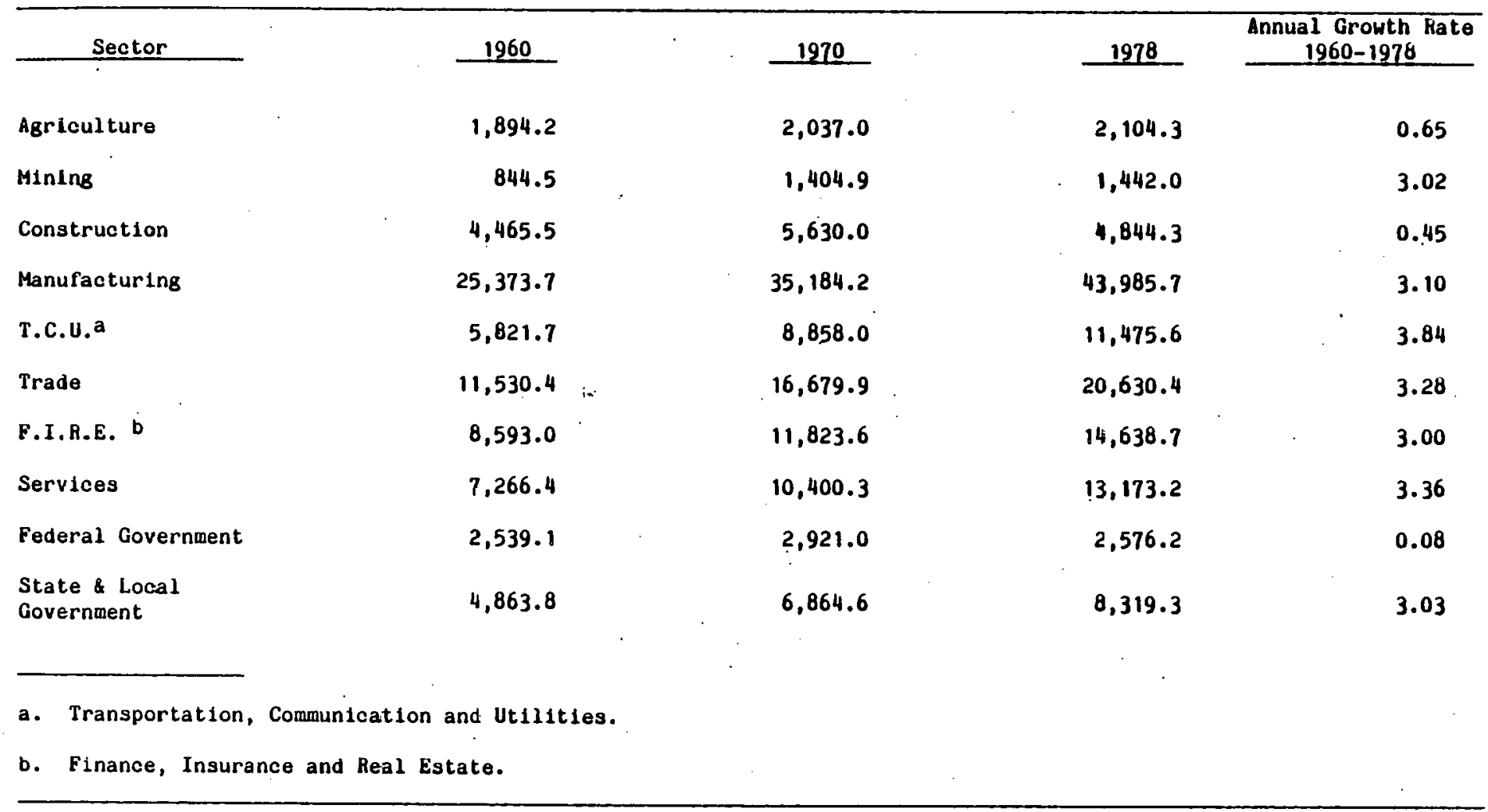

Source: Ohio Department of Community and Economic Development, Office of Research, Gross State Product of Ohio by Industrial Sector, 1980 
TABLE 3-6. OHIO FARM PRODUCTION (Thousands)

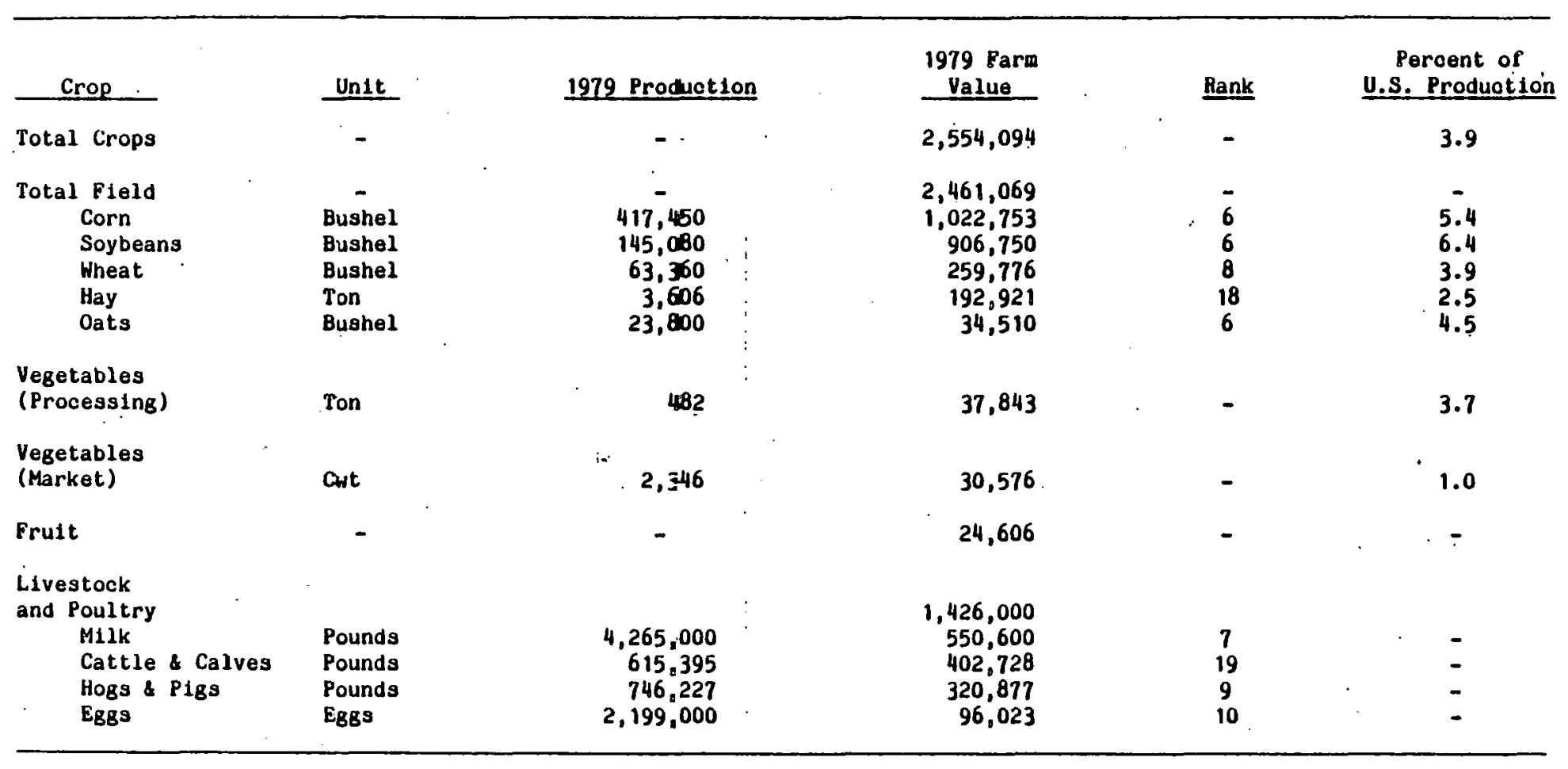

Source: Ohio Crop Reporting Service, Ohio Agricultural Statistics, 1979 
Figure 3-3 shows the fuel mix over time. Coal consumption, which grew rapidly during the end of the 1960 's, remained constant during the 1970's. Natural gas also grew rapidly during the 1960 's and declined during the decade of the 1970's. Despite the price increases of the 1970's, consumption of petroleum has increased at a faster rate than the two other major fuels. 9

Figure 3-4 shows the proportion of energy used by each end-use sector. As would be expected, considering the composition of Ohio's economy, industry is responsible for almost one-half of the energy consumed in the State, followed by the residential, transportation and commercial sectors, each consuming lower amounts of energy in that order. Consumption growth rates dropped for all sectors since the oil embargo, with industrial consumption actually declining (see Table 3-7). 10

\subsection{Electrical Generation and Nuclear Power}

Table 3-8 gives the projected electrical requirements for 1989 and the expected growth rate for the electric regions. The staff of the Divison of Power Supply and Reliability of the Economic Regulatory Administration consider the Reliability Council estimates, derived from composite utility projections, to be excessive. They expect electric growth rates to be about two percent less than predicted by the Reliability Council for at least the next three years. Since a reserve margin of 20 percent is considered sufficient, lower growth rates would allow a reduction in capacity additions. Figure $3-5$ shows that utilities in Ohio have been decreasing their demand projections for a number of years. 11

As Figure 3-6 demonstrates, Ohio utilities rely on coal for baseload generation, and use natural gas and petroleum almost exclusively for generating power to meet peak demand. Nuclear power has not made deep inroads into Ohio's generation mix because it competes directly with coal. Currently there is only one nuclear plant operating in the State, the DavisBesse plant located in Ottawa County. Three more plants are under construction but a number of proposed plants were cancelled in recent years. Details concerning the four nuclear plants are provided in Table 3-9. 


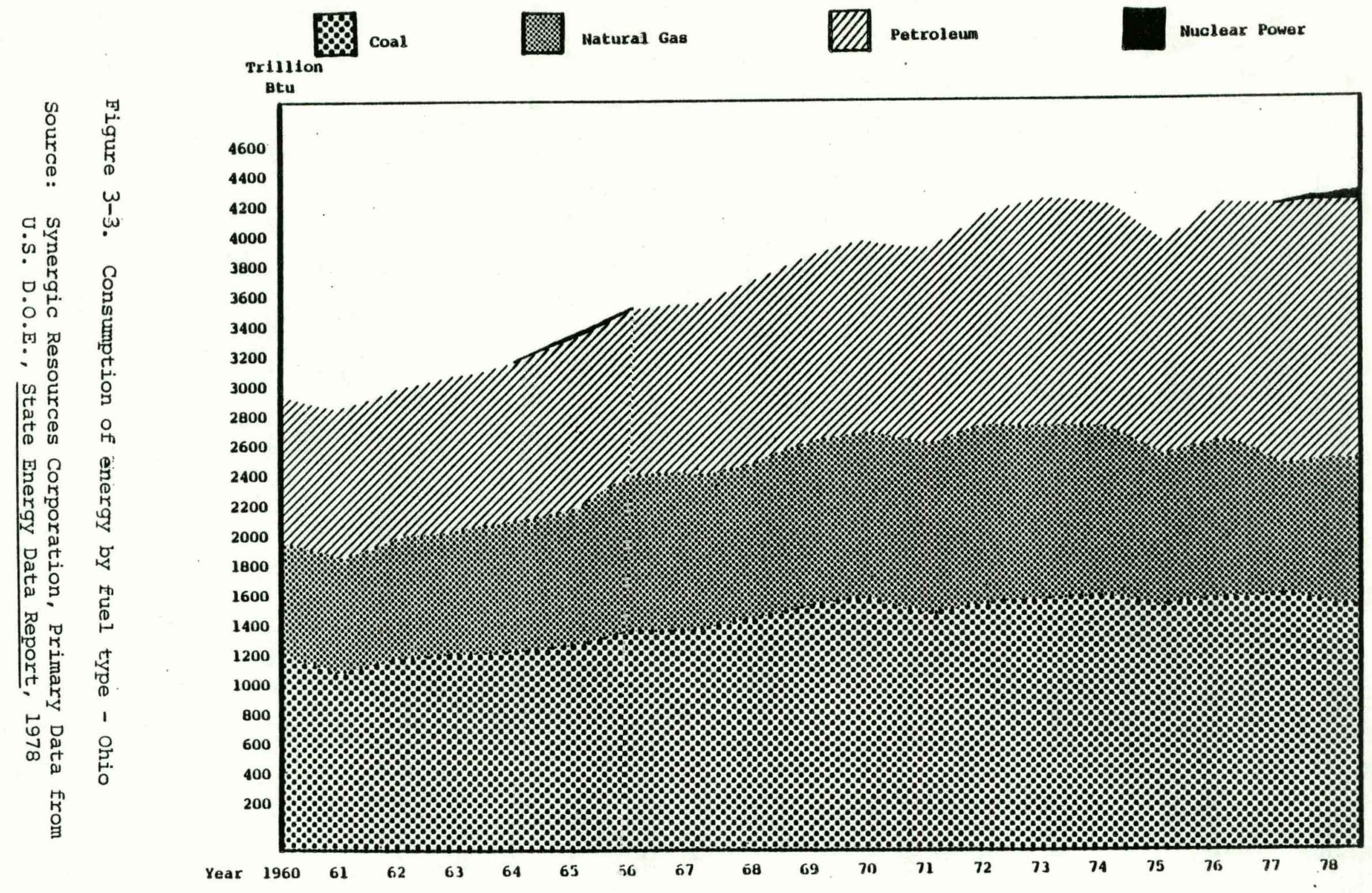




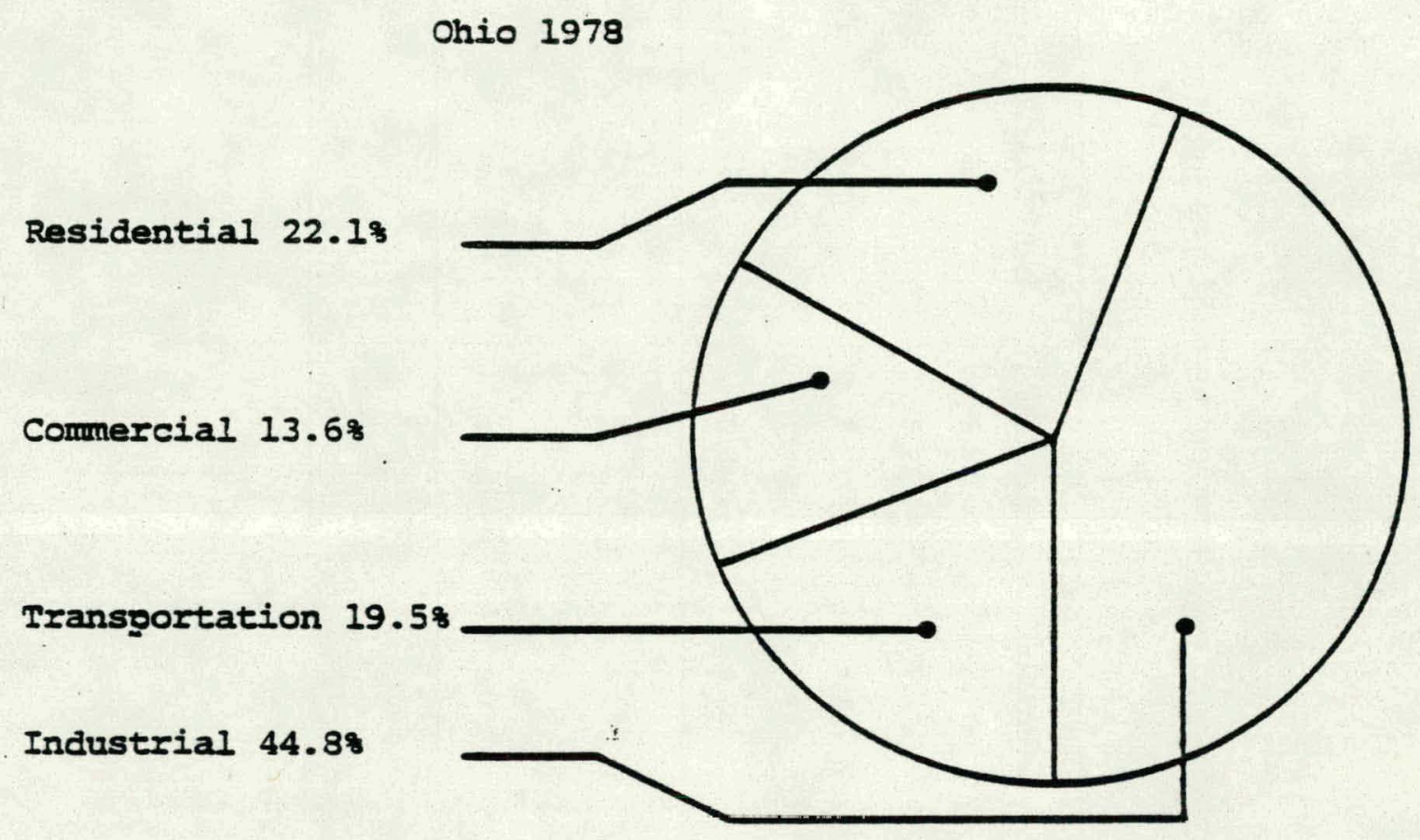

Figure 3-4. Consumption of energy by sector Source: U.S. Dept. of Energy, State Energy Data Report, 1978 
TABLE 3-7. OHIO ENERGY COMSUMPTION BY END-USE SECTOR (Trillion Btu)

\begin{tabular}{lccccc}
\hline Year & Residential & Commercial & Industrial & Transportation & Total \\
\cline { 5 - 6 } 1960 & 612.5 & 337.3 & 1558.3 & 484.2 & 2992.3 \\
1965 & 716.9 & 371.9 & 1729.5 & 543.4 & 3361.7 \\
1970 & 869.6 & 515.9 & 1926.3 & 676.5 & 3988.4 \\
1975 & 893.9 & 543.8 & 1804.1 & 760.4 & 4002.1 \\
1978 & 945.0 & 583.4 & 1918.2 & 834.9 & 4281.5 \\
\hline $1960-1973$ & $2.98 \%$ & $4.26 \%$ & $1.95 \%$ & $3.75 \%$ & $2.77 \%$ \\
Growth & & & & & \\
Rate & $1.01 \%$ & $0.10 \%$ & $-0.88 \%$ & $1.30 \%$ & $0.07 \%$ \\
$1974-1978$ & & & & &
\end{tabular}

Source: U. S. Department of Energy, State Energy Data Report, 1978 
TABLE 3-8. PROJECTED DEMAND BY ELECTRIC REGIONS SERVING OHIO

\begin{tabular}{|c|c|c|c|}
\hline & $\begin{array}{l}\text { Electrical Requirements } \\
\text { (GWH) }\end{array}$ & $\begin{array}{l}\text { Peak Demand } \\
(\mathrm{MW})\end{array}$ & $\begin{array}{l}\text { Reserves Margin } \\
(q)\end{array}$ \\
\hline \multicolumn{4}{|l|}{ AEP } \\
\hline $\begin{array}{l}1979 \\
1989\end{array}$ & $\begin{array}{l}79,420 \\
115,620\end{array}$ & $\begin{array}{l}13,603 \\
20,527\end{array}$ & $\begin{array}{l}24.8 \\
21.9\end{array}$ \\
\hline Annual Growt: & 3.838 & $4.20 \%$ & - \\
\hline CAPCO & is & & \\
\hline $\begin{array}{c}1979 \\
1989 \\
\text { Annual Growth }\end{array}$ & $\begin{array}{l}65,900 \\
90,420 \\
3.22 \%\end{array}$ & $\begin{array}{c}10,809 \\
15,479 \\
3.66 \%\end{array}$ & $\begin{array}{c}25.3 \\
19.5 \\
-\end{array}$ \\
\hline CCD & & & \\
\hline $\begin{array}{c}1979 \\
1989 \\
\text { Annual Growth }\end{array}$ & $\begin{array}{c}35,677 \\
53,780 \\
4,198\end{array}$ & $\begin{array}{c}6,769 \\
10,294 \\
4,288\end{array}$ & $\begin{array}{l}16.9 \\
22.8\end{array}$ \\
\hline
\end{tabular}

Source: U. S. Department of Energy, Economic Regulatory Adninistration, Electric Power Supply and Demand For The Contiguous United States, 1980-1989 


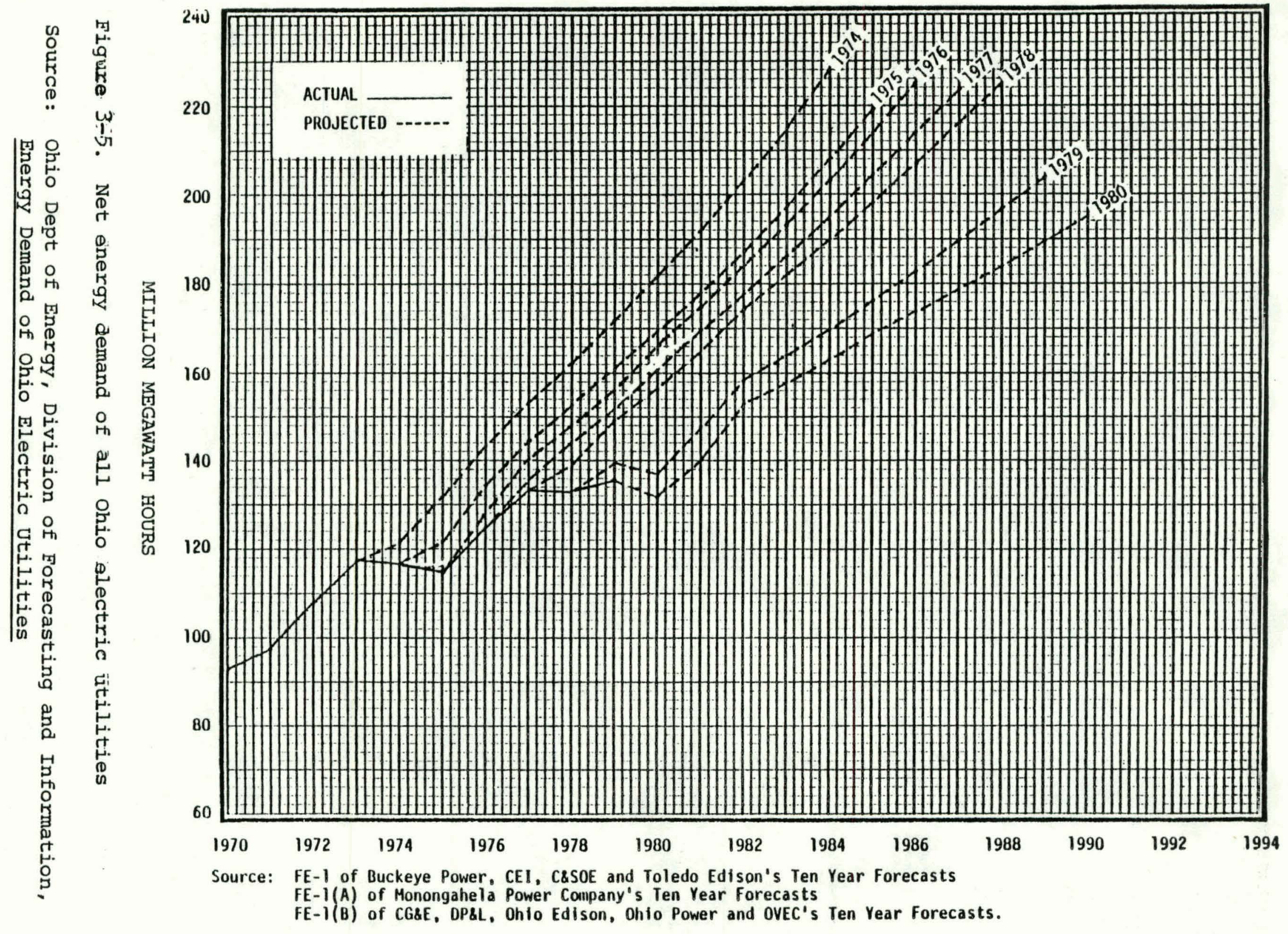




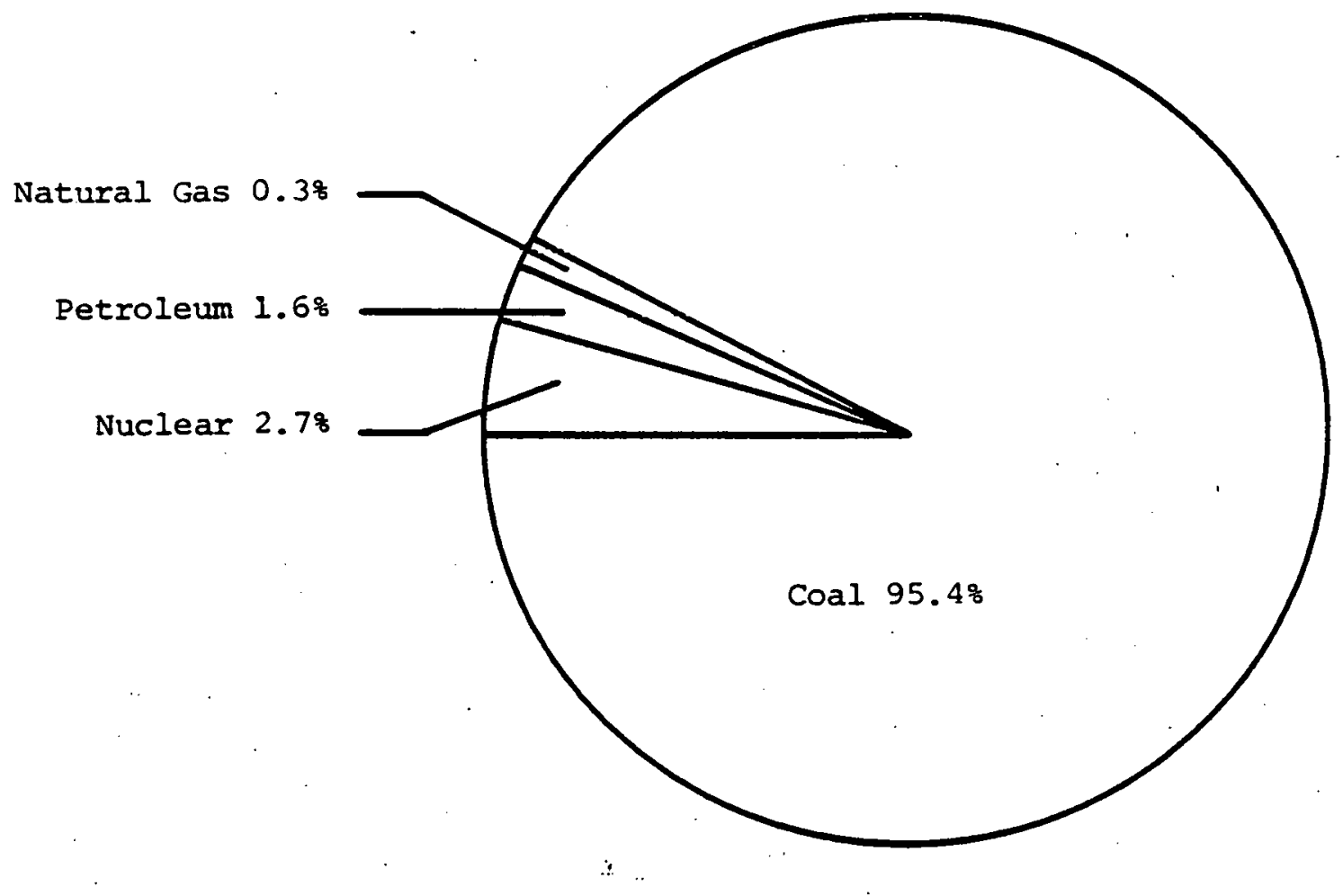

Figure 3-6. Generation Euel wiix of power plants in Ohio

Source: Synergic Resources Corporation, Primary Data from Ohio Department of Energy 
TABLE 3-9. OVERVIEW OF NUCLEAR PLANTS IN OHIO: PRESENT AND PROJECTED

\begin{tabular}{|c|c|c|c|c|}
\hline Plant & Location & Ceppoolty & Ownership & $\begin{array}{c}\text { Year } \\
\text { Operational }\end{array}$ \\
\hline Davis-Besse & $\begin{array}{l}\text { Oak Harbor, } \\
\text { Ottawa County }\end{array}$ & G62 MW & $\begin{array}{l}\text { Toledo Edison } 49.08 \\
\text { Ohto Edison } 36.08 \\
\text { Cleveland Electric } 15.08\end{array}$ & 1977 \\
\hline 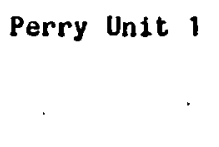 & $\begin{array}{l}\text { North Perry, } \\
\text { Lake County }\end{array}$ & 1205 MW & $\begin{array}{l}\text { Cleveland Electrio } 24.5 \% \\
\text { Ohio Edison } 41.98 \\
\text { Toledo Edison } 19.98 \\
\text { Duquesne L1ght } 13.78\end{array}$ & 1984 \\
\hline Perry Unit 2 & & $1205 \mathrm{MW}$ & & 1986 \\
\hline W. H. 21 mmer & $\begin{array}{l}\text { Moscow, } \\
\text { Clermont County }\end{array}$ & $378 \mathrm{MW}$ & $\begin{array}{l}\text { Cincinnati Gas } 40.0 \$ \\
\text { Dayton Power } 31.5 \$ \\
\text { Columbus \& South } \\
\text { Oh10 28.5\& }\end{array}$ & 1981 \\
\hline
\end{tabular}

Source: U. S. Department of Energy, Energy Information Administration, Inventory of Power Plants In The United States, December, $] 979$ 
Ohio electric utilities are also partially involved with nuclear power plants in Pennsylvania. A nuclear plant in Beaver County is partially owned by Ohio Edison ( 35 percent), and the two Pennsylvania members of CAPCO.. All five CAPCO utilities have part ownership in a second plant at the Beaver site which is currently under construction. In turn, a Pennsylvania utility has partial ownership of the two plants being built in Lake County, Ohio. All plants listed in Table 3-9 are expected to be completed and come on line according to the dates indicated.

* Central Area Power Coordination Group. 
1. U.S. Department of Commerce, Bureau of the Census, Statistical Abstract of the United States, 1979, 100th Edition, U.S. Government Printing Office, Washington, D.C.

2. Ibid.

3. U.S. Department of Commerce, Bureau of the Census, County Business Patterns 1978 Pennsylvania, CRP-7840, U.S. Government Printing Office, September, 1980, Washington Star, World Almanac and Book of Facts, 1979, Newspaper Enterprise Association, Inc. New York; Ohio Department of Economic and Community Development, Office of Research, "Resident Population, United States, and Standard Metropolitan Statistical Areas and Nonmetropolitan Areas, by County, Ohio, 1970-1978, EDS-1.2," Columbus, Ohio 1980; U.S. Department of Commerce, Bureau of the Census, "1980 Preliminary Population Figures for Pennsylvania," Detroit Office, Xerox Copy.

4. Ohio. Department of Economic and Community Development, Office of Research, "Population Projections, by County, Ohio, Quinquennially, 1980-2000, EDS-1.3" Columbus, Ohio 1980; and, Department of Commerce, Bureau of Economic Analysis, Memorandum, to Regional Projections Users, BEA Regional Economic Projections--State summaries, October 14, 1980.

5. U.S. Department of Commerce, Bureau of Economic Analysis, "U.S. Department of Commerce News," State Projections of Personal Income to the Year 2000; Ohio Department of Economic and Community Development, Office of Research, "Unemployment Rate, United States, and by Standard Metropolitan Area and Nonmetropolitan County, Ohio, Annually, 19701979, EDS-3.6"; and, Ohio Bureau of Employment Services, Division of Research and Statistics, "Employment, Hours, and Earnings in Ohio, October 1980," Columbus, Ohio, November 1980.

6. Ohio Department of Economic and Community Development, Office of Research, "Comparison of Ohio Gross State Product with Gross National Product, 1960,1965, and 1970-1978, EDS-8.7," Columbus, Ohio 1980.

7. Ohio Department of Economic and Community Development, Office of Research, "Gross State Product of Ohio by Industry Sector, 1960, 1965 and 1970-1978, EBS-8.2," Columbus, Ohio 1980.

8. Ohio Agricultural Research and Development Center and Ohio State University Department of Agricultural. Economies and Rural Sociology, 1979 Ohio Farm Income, United States Department of Agricultural Economics and Statistics Service, Columbus, Ohio 1980; and, Ohio Crop Reporting Service, Ohio Agricultural Statistics 1979, United States Department of Agriculture, Economics and Statistics Service, Columbus, Ohio 1980. 
9. U.S. Department of Energy, Energy Information Administration, Assistant Administrator for Energy Data Operations, State Energy Data Report, Statistical Tables and Technical Documentation 1960 through 1978, DOE/EIA-0214 (78), Office of Energy Information Services, Washington, D.C., April 1980 .

10. Ohio Department of Energy, Division of Forecasting and Information, "Energy Demand of Ohio Electric Utilities."

11. Edison Electric Institute, Statistical Yearbook of the Electric Utility Industry, 1979, Washington, D.C. November, 1980; and, U.S. Department of Energy, Energy Information Administration, Assistant Administrator for Energy Data Operations, Inventory of Power Plants in the United States December 1979, DOE/EIA-0095 (79), June 1980; and, Ohio Department of Energy, Division of Industry and Information, "Summary of Electric Power Plants of Ohio Utilities 1980". 


\section{GOVERNMENTAL AND PUBLIC ASPECTS}

\section{1 Congressional Representation}

Ohio will be represented in the 97 th Congress by two Democratic Senators along with 10 Democratic and 13 Republican Representatives. The 1980 election produced the same partisan alignment within the Ohio delegation that had existed in the $96 \mathrm{th}$ Congress. However, two incumbent representatives (one Republican and one Democrat) retired and two incumbents (one Republican and one Democrat) were defeated for reelection.

During the 1960's the size of the Ohio delegation to the House of Representatives was 24 seats. Following the 1970 Census, Ohio lost one seat, and is expected to lose two more seats following the reapportionment based on the 1980 Census. Current congressional districts are shown in Figure 4-1. Ohio's delegation in the House of Representatives has consistently held a Republican majority, with margins as large as 19 Republicans to four Democrats following the 1946 election. Recent elections have produced less lopsided margins. Democrats have fared muoh bettor in Senate races, winning seven of the last nine elections.

Ohio's two Senators are John Glenn (Democrat) and Howard Metzenbaum (Democrat). Senator Glenn has devoted much of his efforts to matters of broad national and global policy on which he is considered a moderate. He has been particularly concerned with nuclear proliferation and strategic arms limitations. 1 He has voted for recent legislation (HR.7590, S.2332, and S.2189)* dealing with nuclear waste management. He also sponsored a successful amendment for 5.2189 that allows a State to object to the storage of nuclear waste material within its boundaries, providing that either House of Congress concurs. Senator Glenn's primary contact with the issue of nuclear waste management comes from his service as ranking minority member

*HR.7590, 1981 Appropriations Bill for energy and water projects; S.2332,1981-1982 Appropriations Bill for Department of Energy civilian programs; $S .2189$, a bill to establish Federal storage programs for civilian spent fuel. 


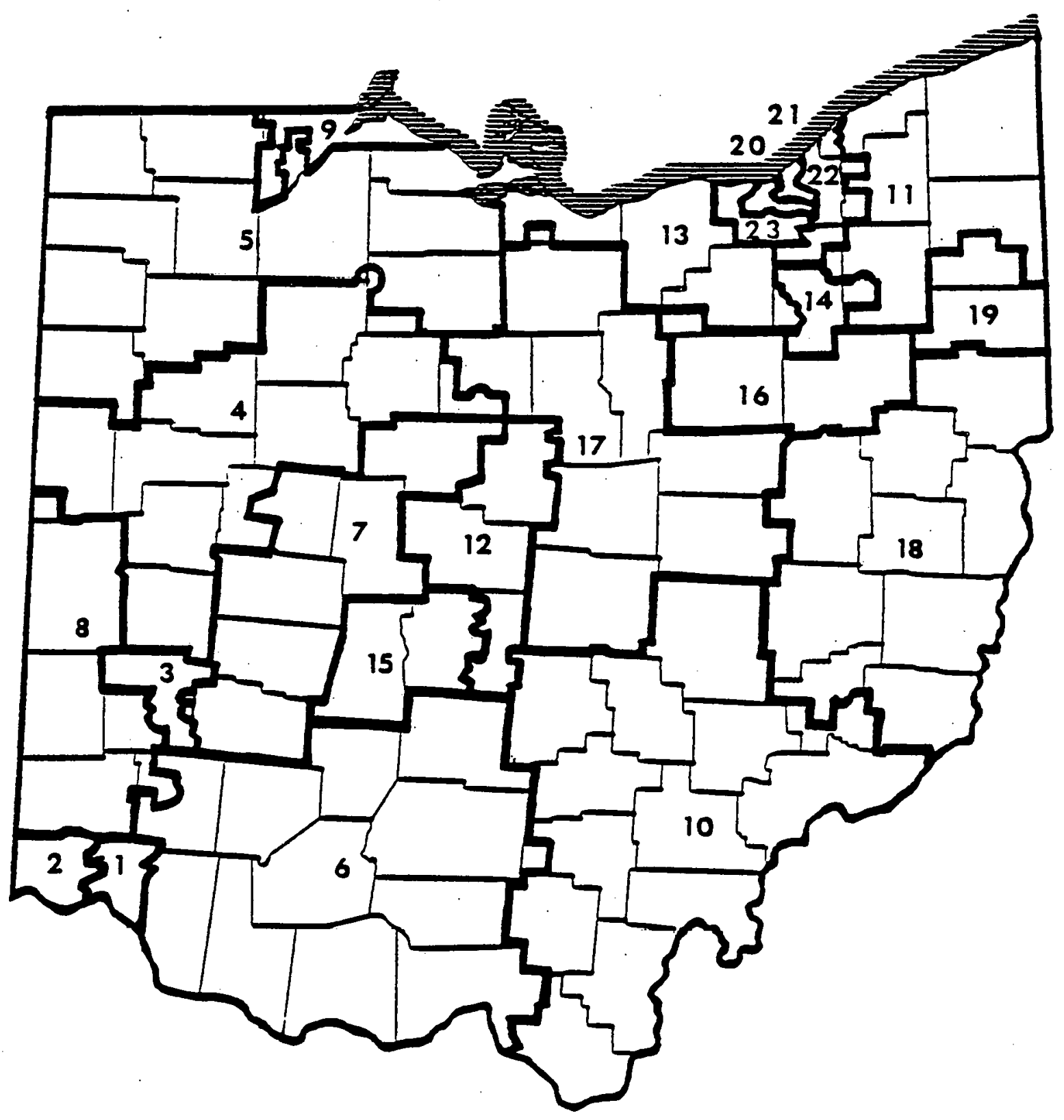

Figure 4-1. Ohio Congressional Districts.

Source: Synergic Resources Corporation 
of the Energy, Nuclear Proliferation and Federal Services Subcommittee of the Governmental Affairs Committee. Senator Metzenbaum has devoted much of his attention to the economic issues that are of prime importance to Ohio. However, he has also been a strong voice in the Senate for environmental protection legislation. He is closely involved with both environmental and energy legislation through his service on the Energy and Natural Resources Committee.2 He, too, has voted in favor of recent legislative measures dealing with-nuclear waste management.

Ohio's 23 members of the House of Representatives are listed in Table 4-1, along with the State's two Senators. This table provides each member's district, party affiliation, date of initial election, and committee assignments.

In the 96th Congress, several of Ohio's House members served on committees relevant to issues of low-level radioactive waste. 3 Serving on Interstate and Foreign Commerce were Thomas Luken (D-2nd district), Clarence Brown (R-7th district), Samuel Devine (R-12th district, defeated in 1980), and Ronald Mottl (D-23rd district). Serving on Government. Operations, were Clarence Brown, Thomas Kindness (R-8th district), and Lyle Williams (R-19th district). Serving on the Science: and Technology Committee was Donald Pease (D-13th district).

The votes of members on recent legislation relating to radioactive waste management are provided in Table 4-2. Ohio's delegation to the House of Representatives generally supported the following bills: HR.6865, authorizing $\$ 5.0$ million for a demonstration project to solidify high-level radioactive wastes; HR.7265, authorizing $\$ 3.5$ billion for Department of Energy research, development, and production of nuclear warheads; and HR.7590, making appropriations for energy and water development, including an atomic weapons program. However, a majority of Ohio's delegation voted against HR.8378, a bill that would have included among other provisions authorization of State compacts for the establishment and operation of regional disposal sites for low-level radioactive wastes. 
TABLE 4-1. OHIO MEMBERS OF THE UNITED STATES CONGRESS

\begin{tabular}{|c|c|c|c|c|}
\hline State Delegate & Distric: & $\begin{array}{c}\text { Political } \\
\text { Affiliation }\end{array}$ & $\begin{array}{l}\text { Beginning of } \\
\text { Present Service } \\
\end{array}$ & Congressional Committees \\
\hline John Glenn & State & Democrat & 1974 & $\begin{array}{l}\text { Foreign Relations } \\
\text { Governmental Affairs } \\
\text { Special Committee on Aging }\end{array}$ \\
\hline Howard Metzenbaum & State & Democrat & 1976 & $\begin{array}{l}\text { Budget } \\
\text { Environment and Public Works } \\
\text { Finance }\end{array}$ \\
\hline Willis D. Gradison & First & Republican & 1974 & Ways and Means \\
\hline Thomas A. Luken & Second & Democrat & 1976 & $\begin{array}{l}\text { Energy and Commerce } \\
\text { Small Business }\end{array}$ \\
\hline Tony P. Hall. & Third & Democrat & 1978 & Rules \\
\hline Tennyson Guyer & Fourth & Republican & 1972 & $\begin{array}{l}\text { Foreign Affairs } \\
\text { Veterans' Affairs }\end{array}$ \\
\hline Delbert L. Latta & Fifth & Republican & 1958 & Budget \\
\hline Bob McEwen ${ }^{a}$ & Sixtr: & Republican & 1980 & $\begin{array}{l}\text { Rules } \\
\text { Public Works and Transportation } \\
\text { Veterans Affairs }\end{array}$ \\
\hline Clarence.J. Brown & Seventh & Republican & 1965 & $\begin{array}{l}\text { Government Operations } \\
\text { Energy and Commerce }\end{array}$ \\
\hline Thomas N. Kindness & Eighth & Republican & 1974 & $\begin{array}{l}\text { Government Operations } \\
\text { Judiciary }\end{array}$ \\
\hline Edward Weber ${ }^{b}$ & Ninth & Republican & 1980 & $\begin{array}{l}\text { Banking, Finance and Urban Affairs } \\
\text { Small Business }\end{array}$ \\
\hline
\end{tabular}


TABLE 4-1. (Continued)

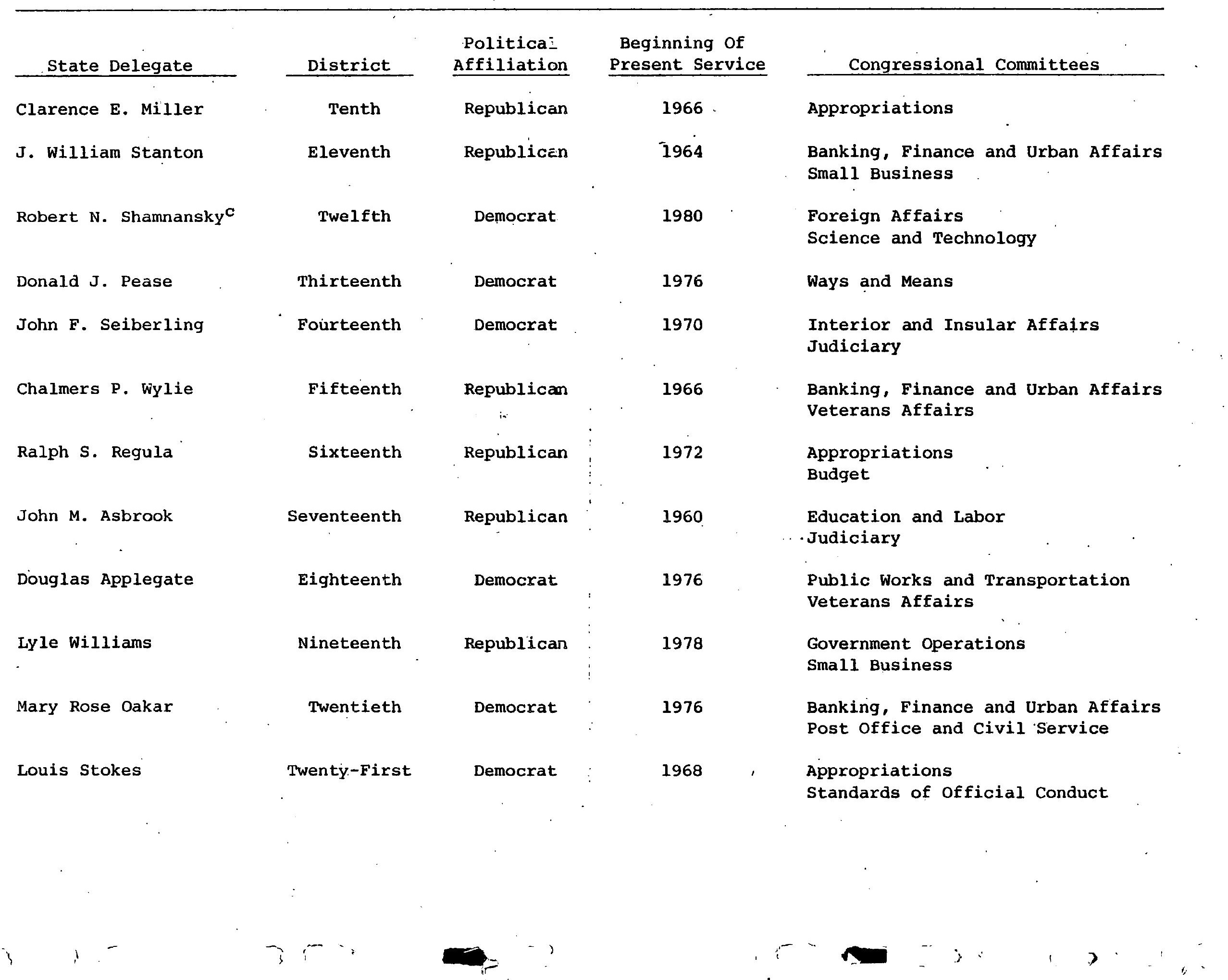


TABLE 4-1. (Continued)

\begin{tabular}{|c|c|c|c|c|c|}
\hline State & Delegate & District & $\begin{array}{c}\text { Political } \\
\text { Affiliation } \\
\end{array}$ & $\begin{array}{c}\text { Beginning of } \\
\text { Present Service }\end{array}$ & Congressional Committees \\
\hline Dennis $\mathrm{E}$. & Eckart & Twenty-Second & Democrat & 1980 & $\begin{array}{l}\text { Education and Labor } \\
\text { Foreign Affairs } \\
\text { Small Business }\end{array}$ \\
\hline Ronald $M$. & Mott1 & Twenty-Thixd & Democrat & 1974 & $\begin{array}{l}\text { Energy and Commerce } \\
\text { Veterans Affairs }\end{array}$ \\
\hline
\end{tabular}

a. McEwan replaces William Harsha, a Republican first elected in 1960 , who served on the Punlic Works and Transportation Committee. This committee deals with most air and water pollution. Harsha favored economic interests over envirormental concerns.

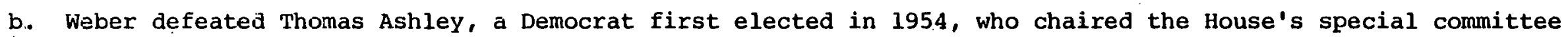
on energy.

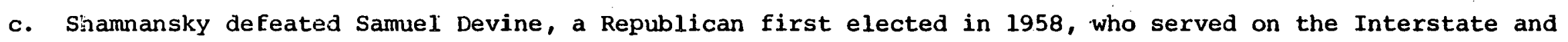
Foreign Commerce Committee and who was generally pro-business and anti-regulation. 
TABLE 4-2. VOTES OF OHIO CONGRESSMEN ON RECENT RELEVANT LEGISLATION ${ }^{4}$

\begin{tabular}{|c|c|c|c|c|c|c|}
\hline I. Senate & HR7590 & $\mathbf{s} 2333$ & $\underline{52332(a)}$ & S2189 & $\$ 2189(a)$ & $\$ 2189(\mathrm{~b})$ \\
\hline Glenn (D) & $Y$ & $\mathrm{Y}$ & $Y$ & $Y$ & $\mathrm{~N}$ & $Y$ \\
\hline Metzenbaum (D) & $\mathbf{Y}$ & $\mathrm{Y}$ & $\mathrm{Y}$ & $Y$ & $\mathbf{Y}$ & $\mathrm{Y}$ \\
\hline
\end{tabular}

II. House

HR6865 HR7265 HR7590 HR7590(a) HR7590(b) HR8378(a).

1. Gradison ( $R$ )

2. Luken (D)

3. Hall (D)

4. Guyer (R)

5. Latta (R)

6. Havsha (R)

7. Brown (R)

8. Kindness (R)

9. Ashley (D)

10. Miller (R)

11. Stanton (R)

12. Devine (R)

13. Pease (D)

14. Seiberling (D)

15. Wylie (R)

16. Regula (R)

17. Ashbrook (R)

18. Applegate (D)

19. Williams (R)

20. Oaker (D)

21. Stokes (D)

22. Vanik (D)

23. Mott1 (D)

$\begin{array}{ll}\mathrm{Y}^{\mathrm{a}} & \mathrm{Y} \\ \mathrm{Y} & \mathrm{Y} \\ ?^{c} & ? \\ \mathrm{Y} & \mathrm{Y} \\ \mathrm{Y} & \mathrm{Y} \\ ? & \mathrm{Y} \\ ? & ? \\ \mathrm{Y} & \mathrm{Y} \\ \mathrm{Y} & ? \\ \mathrm{Y} & \mathrm{Y} \\ \mathrm{Y} & \mathrm{Y} \\ \mathrm{Y} & \mathrm{Y} \\ ? & \mathrm{Y} \\ \mathrm{Y} & \mathrm{N} \\ \mathrm{Y} & \mathrm{Y} \\ \mathrm{Y} & \mathrm{Y} \\ \mathrm{Y} & \mathrm{Y} \\ ? & \mathrm{Y} \\ ? & ? \\ \mathrm{Y} & \mathrm{Y} \\ \mathrm{Y} & \mathrm{N} \\ ? & \mathrm{~N} \\ ? & \mathrm{Y}\end{array}$

$\begin{array}{ll}N^{b} & N \\ Y & N \\ Y & Y \\ Y & Y \\ N & N \\ Y & Y \\ Y & Y \\ Y & N \\ Y & Y \\ N & N \\ Y & Y \\ N & N \\ Y & N \\ Y & N \\ Y & Y \\ Y & Y \\ Y & Y \\ Y & N \\ Y & Y \\ Y & Y \\ Y & Y \\ Y & ? \\ N & N\end{array}$

$\begin{array}{ll}\mathrm{N} & \mathrm{N} \\ \mathrm{Y} & \mathrm{N} \\ ? & ? \\ \mathrm{Y} & \mathrm{Y} \\ \mathrm{Y} & \mathrm{Y} \\ \mathrm{Y} & \mathrm{N} \\ \mathrm{N} & \mathrm{N} \\ \mathrm{N} & \mathrm{Y} \\ \mathrm{Y} & ? \\ \mathrm{~N} & \mathrm{Y} \\ \mathrm{Y} & \mathrm{N} \\ \mathrm{N} & \mathrm{N} \\ \mathrm{N} & \mathrm{N} \\ \mathrm{N} & \mathrm{Y} \\ \mathrm{Y} & \mathrm{N} \\ \mathrm{Y} & \mathrm{N} \\ \mathrm{Y} & \mathrm{Y} \\ \mathrm{N} & \mathrm{N} \\ \mathrm{Y} & \mathrm{Y} \\ \mathrm{Y} & \mathrm{N} \\ \mathrm{N} & \mathrm{Y} \\ \mathrm{Y} & \mathrm{N} \\ \mathrm{N} & \# \mathrm{~d}\end{array}$

*a. $Y=$ For

b. $N=$ Against

c. ? = Did not vote or otherwise make position known.

d. \# = Paired for.

KEY: HR7590 -- A bill to appropriate $\$ 12$ billion for energy and water projects in fiscal 1981, including \$10 million for "away-from-reactor" storage of spent nuclear fuel from commercial power plants. Passed in House. Passed in Senate 83-9.

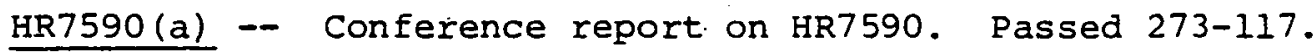

HR7590(b) -- Motion to agree to Senate amendment to authorize a $\$ 284$ million flood control project in the Tug Fork River Valley along the Kentucky-West Virginia border. Motion agreed to 230-164. 
S2332 -- A bill to authorize appropriations to the Department of Energy for civilian programs for fiscal 1981 and fiscal 1982. Passed 78-14.

S2332(a) -- An amendment to restrict the use of $\$ 300$ million authorization for interim Federal storage of nuclear waste until an overall Federal nuclear waste disposal policy was legally in place. Passed 49-44.

S2189 -- A bill to establish a program for Federal storage of spent fuel from civilian nuclear power plants, to set forth a Federal policy and initiate a program for the disposal of nuclear waste from civilian activities. Passed $88-7$.

S2189(a) -- An amendment sponsored by Glenn (D-Ohio) to allow a state's objection to the storage of nuclear waste within its boundaries to be upheld if either house of Congress endorses the State's position. Adopted 83-0

S2189(b) -- A motion made by Johnston (D-La.) to table the Hart (D-Colo.) amendment to restrict the use of Federal away-from-reactor storage of nuclear waste projects to those utilities that no longer had storage space available to reactor sites. Motion agreed to $51-44$.

HR6865 -- Demand for a second on the McCormack (D-Wash.) motion to suspend the rules and pass the bill to authorize $\$ 5$ million for the Energy Department demonstration project at West Valley, New York, to solidify high-level liquid radioactive wastes. Second ordered 244-0. Bill subsequently passed by voice vote.

HR7265 -- A bill to authorize fiscal 1981 spending of $\$ 3.5$ billion by the Department of Energy for research, development, and production of nuclear warheads and other items used by the Defense Department. Two amendments, one which added $\$ 10$ million for design of a radioactive waste processing facility at Savannah River, South Carolina, were passed by voice vote. Passed on November 20,1980 , but later vacated for $\$ 3074$.

HR8378(a) - Amendment to HR8378 (passed by voice vote) to permit states to veto Federally selected nuclear waste sites within their borders unless both houses of Congress voted to override the veto. Rejected $161-2.18$. 


\subsection{State Government}

\subsubsection{Constitution}

The structure and authority of Ohio State government is given broad definition in the Ohio Constitution. Ohio's current Constitution is the State's second document, having been adopted in 1851. The form of government provided in the Constitution is patterned after the national government: a bill of rights; separate legislative, executive, and judicial branches; and amendment procedures. Like most state constitutions, however, it provides for more specific guidance on important legislative matters.

The Ohio Constitution provides for both the initiative and referendum procedures for direct passage of legislation by the voters. Proposed laws may be placed on the ballot by an initiative petition bearing the signatures of at least three percent of the electorate. Referendums on laws are required by the Constitution on certain matters and may also be required by a petition bearing six percent of the electorate.

\subsubsection{Executive Branch}

The Constitution of Ohio provides for an executive department consisting of a Governor, Lieutenant Governor, Secretary of State, Auditor of State, Treasurer of State, and Attorney General. All members of the executive department are elected for four-year terms. In addition to the four departments created by the State Constitution (State, Auditor, Treasurer, and Attorney General), there are currently 22 departments created by statute.

4.2.2.1 Governor. The Governor of Ohio is James A. Rhodes, a Republican whose present term expires in January, 1983. Governor Rhodes is serving in his fourth four-year term. He served as Governor from 1963 to 1971, when the State Constitution barred him from seeking a third consecutive term. He returned to office in 1975. Rhodes won his last two elections by narrow margins and in 1982 will again be ineligible for 
reelection. The Governor appoints the administrative leaders of executive departments, who are responsible to him. He also appoints the Adjutant General, members of most State boards and commissions, and some division heads within departments. The Governor in ohio has full responsibility for preparing the State's budget and has the power to veto line items within bills passed by the General Assembly. A study of State gubernatorial authority has ranked the Ohio Governor as the 12th most powerful governor of the 50 states. 4

Prior to 1958 the term of office for Ohio governors was two years. Since World War II, Democrats and Republicans have evenly split the 12 gubernatorial elections, with Governor Rhodes accounting for four of the Republican's six victories. Thus, gubernatorial elections have reflected the close competition between the two parties in ohio politics.

Governor Rhodes has pursued policies of low taxes, low levels of service, and encouragement of industrial development.

Below are listed the major executive offices and the current officeholder:

\author{
Lieutenant Governor: (Vacant) \\ Secretary of State: Anthony J. Celebrezze, Jr., Democrat \\ Auditor of State: Thomas E. Ferguson, Democrat \\ Treasurer of State: Gertrude W. Donahey, Democrat \\ Attorney General: William J. Brown, Democrat
}

\title{
4.2.2.2 Departments. The Statutes of the State of Ohio have
} established 22 departments within the executive branch. The administrative heads of these departments are appointed by the Governor and are responsible to him. These departments are:

- Department of Administrative Services.

- Department of Agriculture.

- Office of Budget and Management. 
- Department of Commerce.

- Department of Economic and Community Development.

- Bureau of Employment Services.

- Department of Energy.

- Environmental Protection Agency.

- Department of Health.

- Department of Highway Safety.

- Department of Industrial Relations.

- Department of Insurance.

- Department of Liquor Control.

- Department of Mental Health and Retardation.

- Department of Natural Resources.

- Public Utilities Commission.

- Department of Public Welfare.

- Department of Rehabilitation and Correction.

- Department of Taxation.

- Department of Tax Equalization.

- Department of Transportation.

- Ohio Youth Commission. 
An important department not included within the 22 cabinet departments is the Department of Education, whose head is appointed by and is responsible to the State Board of Education. A listing of State agencies by policy responsibility is provided in Figure 4-2.

There are a number of departments and advisory bodies whose authority may relate directly to nuclear energy and waste control.

The Department of Energy was established as a cabinet-level department in 1977. It is mandated to provide for the full development of all energy sources indigenous to Ohio in order to provide adequate supplies of all forms of energy at the lowest possible cost to the consumer. The department has divisions of Research and Development, Forecasting and Information, Planning, and Conservation. This department is responsible for forecasting electric and natural gas supply/demand. It also implements a number of energy conservation programs funded by the Energy Policy and Conservation Act of 1975 and the Energy Conservation and Production Act of 1976.

The Energy Advisory Council serves to advise and recommend certain energy policies for the consideration of the Director of the Department of Energy. It is made up of 15 representatives of citizen interest groups apppointed by the Governor and subject to approval by the Ohio. Senate, plus four members of the Ohio General Assembly.

The Environmental Protection Agency includes the following divisions: Office of Land Pollution Control; Office of Air Pollution Control; Office of Public Water Safety; Office of Wastewater Pollution Control; Office of District Operations; Office of Operational Support; Environmental Legislative Liaison; Environmental Legal Advisor; Environmental Planning Coordinator; Emergency Response; and Public Interest Center/Environmental Information.

The Office of Land Pollution Control directs the control and disposal of solid waste in the State. The Division of Solid Waste Management reviews disposal plans, prepares guidelines for site investigations, conducts local 


\section{OHIO}

ADUUTANT GENERAL

James C. Clem, Adjutant General

Adjusant General's Department

2825 W. Dublin-Granville Rd.

Worthington OH 43085

(614) 889-7070

NDMINISTRATION

Richerd D. Jackson, Director

Department of Administrative Services

State Office Tower

30 E Broad St.

Columbus OH 43215

(614) 466-6511

AERONAUTICS

Norman Crabtree, Depury Director

Division of Aviation

Department of Transportation

2829 W. Granville Rd.

Worhington $\mathrm{OH} 43085$

(614) $466-7120$

AOING

Martin A. Janis, Executive Director Commiestion on Aging

$50 \mathrm{~W}$. Broad St.

Columibus OH 43215

(614) $466-5500$

\section{AGRICULTURE}

John M. Stackhouse, Director

Deparment of Agriculture

713 State Office Bldg.

65 S. Front St

Colomisus OH 43215

(614) $466-2732$

AAR POLLUTION CONTROL

Chuck Tay lor, Chief

Office of Air Pollution Control

Onio Environmental Protection Agency

Seneca Towers

361 E Broad St.

P.O. Box 1049 (43216)

Columbus $\mathrm{OH} 43215$

(614) $466-6116$

\section{ALCOHOLISH}

Paul Lanbam, Chief

Division of Alcoholism

Depar:ment of Healih

246 N. Sigh St

Columbus $\mathrm{OH} 43215$

(614) $466-3445$
ARCHIVES AND RECORDS

Frank Levstik, State Archivist

The Ohio Historical Society

Interstate 71 at 17 th Ave.

Columbus OH 43211

(614) $466-2060$

ARTS AND HUMANITIES

Wayne P. Lawson, Direetos

Ohio Ars Conneil

SO W. Broad St.

Columbus $\mathrm{OH} 43215$

(614) $466-2613$

Charles C. Cole, Jr, Executive Director Ohio Program in the Humarities

760 Pleasant Ridge Ave.

Columbus OH 43209

(614) 236-6879

\section{ATTORNEY GENERAL}

William J. Brown, Anorney General

State Office Tower

30 E. Broad St.

Columbus. $\mathrm{OH} 43215$

(614) $466-3376$

AuDrT

Thomas E. Ferguson, Auditor of State

$88 \mathrm{E}$ Broad St, Sth Fl.

Columbus $\mathrm{OH} 43215$

(614) $466-4858$

BANKING

R. Hal Nichols. Superintendent of Banks Division of Banks

Department of Commerce

Borden Bldg

180 E. Broad St.

Culumbus $\mathrm{OH} 43215$

(614) $466-2932$

\section{BUDGET}

William W. Wilkins. Director

Office of Budget and Management

State Office Tower. 39th Fi.

30 E. Broad St.

Columbus $\mathrm{OH} 43215$

(614) 466-4034

Figure 4-2. Ohio State agencies.

Source: The National Directory of State Agencies, 1978-1979, (Washington, D.C. Information Resources Press - 1978). 


\section{CHILD WELFARE}

David W. Schwertfager, Chief

Bureau of Chiidren Services

Division of Social Services

Department of Public Welfare

State Office Tower, 30th Fl, Sect. D

30 E Broad St.

Columbus OH 43215

(614) $466-2208$

CIVIL DEFENSE

Curtis Griffith, Ir.. Deputy Director

Disaster Senvices Agency

Adjutant General's Departmeni

2825 W. Dublin-Granville Rd.

Worthington OH 43085

(614) 889-7150

\section{CLEAK OF THE HOUSE}

Joseph J. Sommer, Executive Secretary

House of Representatives

State House

Broad and High Sts.

Columbus OH 43215

(614) $466-4308$

\section{COMMEACE}

J. Gordon Peltier, Director

Department of Commence

Borden Bldg.

180 E Broad St.

Columbus OH 43215

(614) $466-3636$

\section{COMMUNITY AFFAIRS}

James A. Duerk

Department of Economic and Community Development

State Office Tower

30 E Broad St

P.O. Box 1001 ( 43210$)$

Columbus OH 43215

(614) $466-7610$

\section{CONFLCT OF INTEREST}

Richard G. Terapak, Executive Director

Ohio Ethics. Commission

150 E. Broad St.

Columbus $\mathrm{OH} 43215$

(614) 466-7093

\section{CONSUMER AFFAIRS}

Rober S. Tongren, Chief

Consumer Frauds and Crimes Section

Office of the Attomey General

State Office Fower

30 E. Broad St.

Columbus OH 43215

(614) $466-8831$

\section{CORAECTIONS}

George F. Denton. Director

Department of Rehubilitation and Corrections

1050 Freeway Dr.. N.

Columbus OH 43229

(614) $456-6190$
COUFT ADMINISTRATION

Coit H. Gilbert, Adtainistrative Director of the Cours

Supreme Court of Ohio

State Office Tower

30 E Broad St.

Columbus OH 43215

(614) $466-2653$

\section{DATA PROCESSING}

Jerry Hammeth, Deputy Director

Division of Computer Services

Department of Administrative Services

Scate Office Tower, 39th FI.

30 E Broad St.

Columbus OH 43215

(614) $466-6920$

DaUg ABUSE

Met Zarissler, Chief

Burean of Drug Abuse

Division of Mental Health

Deparment of Mental Health and Mental Retardation

1352 State Office Tower

30 E Braad St.

Columbus OH 43215

(614) 466-7604

ECONOMIC DEVELOPMENT

Al Wallace, Deputy Director

Ecanomic Development Division

Department of Economic and Community Development

State Office Tower, 23nd F.

30 E Broad St.

Columbus OH 43215

(614) $466-2317$

EDUCATION (highor)

James A. Norton, Chanceilor

Board of Regents

State Office Tower

30 E Broad SL.

Columbus OH 43215

(614) $466-6000$

EDUCATION (primary, secondary, and vocatlonal)

Franktin B. Walter, Superintendent of Public Instruction

Depariment of Ectucation

808 State Office Bldg.

$65 \mathrm{~S}$. Eront St.

Columbus OH 43215

(614) $466-3304$

\section{EI ECTIONS}

James R. Marsh, Assistant Sectetary of Stace Elections Section

Office of the Secretary of State

State Office Tower

30 . E Broad St.

Columbus OH 43215

(614) 466-2585

Figure 4-2. (Continued) 


\section{EMPLOYMENT SECURTY}

Albert G. Giles, Administrator

Burean of Employment Services

$145 \mathrm{~S}$. Front St

Columbus OH 43216

(614) 466.2100

\section{ENERGY}

Rober S. Ryan, Director

Deparmment of Energy

State Office Tower, 34th FL

30 E Brond SL

Columbus OH 43215

(614) $466-3465$

\section{ENMIRONMENTAL AFFAIRS}

James A. McAvoY, Director

Ohio Envirormertal Protection Agency

361 E Broad St.

Columbus OH 43215

(614) $466-8318$

\section{FEDERAL-STATE RELATIONS}

Thomes J. Granth Governor's Liaison Warhingron Office

Stase of Ohio

1150 Connecticut Ave, N.W.

Washington DC 20036

(202) 223-1725

finance

William W. Willans. Director

Office of Budger and Management

State Office Tower, 39th FL

30 E Broad St

Columbus OH 43215

(614) $466-4034$

\section{FBH AND GAME}

Clayrod Lakes, Supervisor

Fish Maragemens Section

Division' of Widtipe.

Depariment of Narural Resources

Fountain Sq.

Columbus OH 43224

(614) $466-3630$

Dale L. Haney, Chief

Division of Wildifie

Department of Nirural Resources

Fountain Sa.

Columbus OH 43224

(614) $466-7313$

FOOD AND DAUGS

Johs E. Taylor. Chief

Division of Foods, Dairies, and Drugs

Deparment of 4 unculiure

8095 E. Main St.

Revoolésburg OH 43068

(614) $\times 66-6361$

FORESTRY

Entest I. Creblart Chief

Division of Forest?

Departmen! of Niajural Resources

Fountan So.

Collinous $\mathrm{OH} \leqslant 5224$

(614) $466-7842$
GENERAL SERVICES

Waller L. McCreary, Deputy Director Division of Office Services

Department of Administrative Services

State Office Tower, 40th FL.

30 E Brosd St

Columbus $\mathrm{OH} 43215$

(614) 466-5087

\section{GEOLOGY}

Horace R Collins, Chief

Division of Geological Survey

Department of Natural Resources

Fountain Sq., Bldg. B

Columbus OH 43224

(614) 466-5344

HEALTH

John Ackerman, Director

Deparment of Heallh

246 N. High St.

Columbus $\mathrm{OH} 43215$

(614) $466-2253$

HICHWAY SAFETY

Robert M. Chiaramonte, Director Department of Highway Safery

240 Parsons Ave.

Columbus OH 43215

(614) $466-3383$

HIGHWAYS

David L Weir, Director

Department of Transportation

$25 \mathrm{~S}$. Front St.

Columbus OH 43215

(614) $466-2335$

MISTORIC PRËSERVATION

Thomas H. Smith, Director

The Ohio Historical Sociery

Interstate 71 at 17th Ave.

Columbus $\mathrm{OH} 43211$

(614) $466-1500$

HOUSINE

William A. Losoncy, Executive Director

Ohio Housing Development Board

34 N. Higb St

Columbus $\mathrm{OH} 43215$

(614) $466-7970$

\section{HUMAN RIGHTS}

Ellis L. Ross, Executive Director

Ohio Civil Rights Commission

220 Parsons Ave.

Columbus $\mathrm{OH} 43215$

(614) $466-2785$

\section{INSUAANCE}

Harry V. Jump, Director

Deiwriment of Insurance

iliv) Stella Ct.

Colimbus $\mathrm{OH} 43215$

(614) 466-3584

Figure 4-2. (Continued) 
JUVENILE OELUNQUENCY

William K. Willix, Director

Ohio Youth Commission

Nitschke Bldg.

35 E Gay St.

Columbus $\mathrm{OH} .43215$

(614) $466-8783$

LABOR

Helen W. Evans, Director.

Department of Industrial Relations

2323 W. Sth Ave.

Columbus OH 43216

(614) $466-3271$

LAW ENFORCEMENT PLANNING

Alphonso Montgomery, Deputy Director Administration of Justice Division

Department of Economic and Commanrity Development

Stale Office Tower, 26th FL

30 E Broad St.

Columbus $\mathrm{OH} 43215$

(614) $466-7610$

\section{LEGISLATIVE RESEARCM}

David A. Johnston, Director

Legislative Service Commission

State House

Broad and High Sts.

Columbus OH 43215

(614) $466-3615$

\section{LUAARY SEAVICES}

Ira Phillips, Acting State Librarian

State Libreny of Ohio

State Office Bidg.

$65 \mathrm{~S}$. Front St.

Columbus $\mathrm{OH} 43215$

(614) $466-2693$

\section{LUOUOR CONTROL}

Clifford E Reich, Director

Department of Liquor Control

2323 W. 5th Ave.

Columbus OH 43204

(614) $466-2142$.

\section{LOTTERY}

David R. Harbarger, Executive Director

Ohio Lottery Commission

11001 Cedar Ave.

Cleveland $\mathrm{OH} \$ 4106$

(216) 795-5000

\section{MASS TAMSIT}

Richard $H$. Henderson. Administrator

Bureas of Public Transportation

Division of Planning and Design

Department of Transportation

$25 \mathrm{~S}$. Frone St.

Columbus $\mathrm{OH} 43215$

(614) $466-8955$
MENTAL HEALTH

Timothy B: Moritz, Director

Department of Mental Healsh and Mental

- Retandarion

1182 Stale Office Tower

30 E Broad St.

Columbus $\mathrm{OH} 43215$

(614) 466-2337

MeNTAL RETARDATION

Levester Cannon, Commissioner

Division of Mental Retardation and Developmental Disabilities

Department of Mental Health and Mental Retardation

1284 State Office Tower

$30 \mathrm{E}$ Broad St.

Columbus OH 43215

(614) 466-5214

MiNiNG

Henry J. Ciechomski, Chief

Division of Mines

Department of Indestrial Relations

2323 W. Sth Ave.

P.O. Box 825

Columbus $\mathrm{OH} 43216$

(614) $466-4240$

MOTOR VEHICLES

Dean L. Dollison, Registrar

Bureau of Motor Vehicles

Deparmens of Highway Sajety

4300 Kimberly Pixwy.

P.O. Box 16520 (43215)

Columbus OH 43227

(614) 466-7666.

RATURAL RESOURCES

Rober W. Teater, Director

Department of Narumal Resources

Fountain So

Columbus OH 43224

(614) $466-3770$

\section{NUCLEAR ENEAGY}

Robert S. Ryan, Director

Department of Energy

State Office Tower, 34th FI

30 E Broad St.

Columbus OH 43215

(614) $466-3465$

OCCUPATIONAL SAFETY AND HEALTH

Philip A. Workman: Superintendent

Division of Sujery and Sygiene

Inctustrial Commission of Öhio

$246 \mathrm{~N}$. High Se.

Columbus $\mathrm{OH} 43215$

(614) 466-3564

OIL AND GAS

Andrew Skalkos, Chiet

Oil une Gus Division

Department of Narurai Resources

Fountain Sa. Bldg. B

Columbus $\mathrm{OH} 43224$

(614) 466-3990

Figure 4-2. (Continued) 
PARKS

Ralph Vanzani Chief

Division of Parks and Reereation

Department of Natural Resources

Fountain So

Columbus OH 43224

(6i4) $466-2838$

\section{PERSONNEL}

Pbilip S. Hamilton, Deputy Director

Division of Personnel

Depariment of Adminisenarive Services

- State Office Tower

30 E Broad St:

Columbus $\mathrm{OH} 43215$

(614) $466-3455$

\section{POLCE}

: Adam G. Reiss, Superintendent

Highway Parol

Deparment of Highway Safety

660 E Main St

Columbus OH 43205

(614) $466-2990$

\section{printing ano publishing}

Donald H. Wallar, Administrator

Stave Printing

Division of Office Servios

Department of Administrative Services

183 E. Mound St.

Columbus OH 43216

(614) $466-4914$

\section{PROBATION ANO PAROLE}

Nick J. Sanborn Chief

Division of Parale and Commonity Senvicas Departmins of Rehabilitation and Corrections 1050 Freeviay Dr., N.

Columious OH 43229

(614) $466-6170$

\section{PUBCIC DEFENDER}

J. Tullis Rogers, Public Defender

Pubiic Defender Commission

$20 \mathrm{E}$. Broad St

Columbus OH 43215

(614) 466-5393

\section{PUBLC UTILTIES}

C. Lutner Heckman. Chairman

Public Vitilities Commission

180 E Broad St.

Columbus OH 43215

(614i 466-3102

\section{PUBLC MORKS}

Ravmond R. Kobli, Deputy Director

Division of Public Works

Department of Administrative Services

Staic Office Tower, 35th Fl.

30 E. Broad SL.

Columbus OH 43215

(614) $466-4277$
PURCHASING

John M. Kiger, Administrator

Slare Purchasing Bureau

Division of Office Services

Deparment of Administrative Services

364 S. 4th St.

P.O. Box 329

Columbus OH 43215

(614) 466-8218

\section{RALROADS}

Crarles R. Geer, Chief

Railroad Section

Transportation Department

Public Utilities Commission

Borden Bldg:

180 E Broad St.

Columbus $\mathrm{OH} 43215$

(614) $466-2304$

\section{RETIREMENT}

W. S. McLaughlin, Executive Director Public Employees Retirement Systen

277 E Town St.

Columbus OH 43215

(614) $466-2822$

\section{SECRETARY OF STATE}

Ted W. Brown, Secretary of State

State Office Tower

30 E Broad St.

Columbus OH 43215

(614) $466-2530$

SECRETARY OF THE SEMATE

William H. Chavanne, Clerk

Senate

State House

Broad and High Sts.

Columbus $\mathrm{OH} 43215$

(614) $466: 4900$

\section{SECURITIES}

James Hurd, Commissioner

Division of Securities

Department of Commerce

Borden Bldg. 13th FI.

180 E. Broad St.

Columbus $\mathrm{OH} 43215$

(614) $466-7602$

SOCIAL SEAVICES

Mildred Madry, Chief

Division of Social Services

Department of Public Weffare

State Office Tower

30 E Broad St.

Columbus OH 43215

(614) $466-2306$

\section{SOLID WASTE MANAGEMENT}

Donald Day. Chief

Office of Land Pollution Control

Ohio Environmental Protection Agency

Seneca Towers

361 E. Broad St.

P.O. Box 1049 (43216)

Columbus $\mathrm{OH} 43215$

(614) $466-8934$ 
STATELOCAL RELATIONS

Robert Stuce, Chief

Office of Local Govermment Services

Community Services Division

Department of Economic and Community

Developmen

State Office Tower

30 E Broad SL

P.O. Box 1001 (43216)

Columbus $\mathrm{OH} 43215$

(614) 466-2285

\section{TAXATION AND REYENUE}

Edgar L Lindiey, Tax Commissioner

Ohio Department of Texation

State Office Tower

30 E Broad St.

P.O. Box 530 (43216)

Columbus $\mathrm{OH} 43215$

(614) $466-2166$

\section{TOUAIS:}

Philip D. DeVore, Director

Office of Travel and Tourism

Economic Development Division

Deparment of Ecanomic and Communiny

Development

State Office Tower

30 E Broad SL.

P.O. Box 1001 (43216)

Columbus $\mathrm{OH} 43215$

(614) $466-8844$

\section{TRANSPOATATION}

David L. Weir, Director

Department of Transportation

$25 \mathrm{~S}$. Front St

Columbus $\mathrm{OH} 43215$

(614) $466-2335$

\section{TAEASUAEA}

Gertrude W. Donahey, Treasurer of Stave State Office Tower

30 E Broad St.

Columbus OH 43215

(614) $466-2160$
VETERANS' AFFAIRS

John P. Siemer, Chief

Soloiers' Claim Division

Adjutant General's Deparment

State House Anoex

Columbus OH 43215

(614) 466-5453

VITAL RECORDS/STATISTICS

Karl Wise, Chiet

Division of Visal Statistics

Department of Health

State Office Bldg.

65 S. Front St

Columbus $\mathrm{OH} 43215$

(614) 466-2533

WATER POLLUTION CONTAOL

Emest Rotering, Chief

Office of Wastewacer Pollution Control Ohio Environmental Protection Agency

Seneca Towers

361 E Broad St

Columbus OH 43215

(614) 466-7427

WATER RESOUACES

Andrew Spencer, Admiaistrator

Water Resources Development

Depariment of Natural Resources

Fountain Sa

Columbus OH 43224

(614) $466-6020$

WEFARE

Kenneth B. Creasy, Director

Deparment of Public Welfore

State Office Tower

30 E Broad St

Columbus OH 43215

(614) $466-6282$

\section{WOAKMEN'S COMPEMSATION}

Robert C. Daugherty, Administrator

Burean of Workers' Compensation

246 N. High St.

Columbus OH 43215

(614) $466-2950$

Figure 4-2. (Continued) 
solid waste program surveys, advises local health officers, and approves plans for hazardous waste disposal and recovery. The Division of Planning and Technical Assistance is primarily responsible for identification of planning strategies and procedures at State and local levels, along with the definition of organizational and institutional roles in plan implementation.

The Office of Wastewater Pollution Control develops state-wide water quality management plans. The Division of Industrial Wastewater issues National Pollution Discharge Elimination System (NPDES) permits and enforces these permit requirements. The Division of Surveillance, Planning, and Laboratory Services collects data and reports trends in water quality, and evaluates special toxic effluent problems.

The Office of Emergency Response provides an on-the-scene coordinator to respond to environmental emergencies. Personnel conduct field monitoring and may recommend evacuations when citizen health is endangered. Since 1972 the Office has responded to more than 4,000 pollution incidents, in addition to providing technical assistance for off-loading or removal operations of potentially hazardous materials.

The Department of Health adopts and administers health and sanitary regulations which have general application throughout the State. The department includes a Public Health Council, a director, several divisions, four district officers, and a central and four branch laboratories. The department provides a Bureau of Environmental Health and a Division of General Environmental Health Services. The Bureau of Radiological Protection is also located in this department and it is responsible for responding to incidents pertaining to radiological waste.

The Department of Natural Resources is responsible for the formulation and execution of a comprehensive plan for the development and use of natural resources within the State. The Lands and Soil Division is responsible for the inventory of soil resources of the State and assistance in soil conservation work and land use planning. The Water Division coordinates all major State and regional water resources programs. 
The Public Utilities Commission regulates a wide variety of utilities in the State, including railroads, electric light companies, motor carriers, and sewage disposal companies. The commission consists of three members, each of whom is appointed by the Governor with the advice and consent of the Senate. The commission has authority over utilities rate structure, safety operations, and legal compliance.

The Department of Transportation is charged with planning, constructing, and maintaining a balanced system of transportation. There are six basic functional units within the department. These include Administrative Affairs, which is responsible for safety and operations, and supervises all activities involving maintenance and operations.

\subsubsection{Legislative Branch}

4.2.3.1 General Features. Under the Ohio Constitution, the legislative functions of State government are assigned to the General Assembly. The General Assembly is a bicameral body consisting of a 99member House of Representatives and a 33-member Senate. Members of the House of Representatives are elected for two-year terms. Members of the Senate are elected for four-year terms, with half the membership elected every two years.

Following each biennial election, the General Assembly meets for two sessions. The first regular session convenes on the first Monday of January in the odd-numbered year, or the succeeding day if the first Monday is a legal holiday. The first session continues throughout the year, and is usually longer than the second session. The second session convenes in the even-numbered year and continues the business of the first session.

4.2.3.2 Powers of the General Assembly. The legislative power of the General Assembly is subject to the limitations and restrictions provided by the Ohio and United States Constitutions. In addition to its policy-making powers, the General Assembly may propose constitutional amendments, impeach executive officers, regulate elections, establish State courts, provide for the qualification of its own members, and establish its own procedures. 
Among its most important powers is its responsibility for local government and taxation. The General Assembly provides for alternative forms of county and municipal government, subject to the limit of constitutional provision for local home rule. In the absence of charter authority, the authority of State statutes is binding upon local government. The General Assembly is also accorded the implied power to tax. However, the Assembly may delegate its taxing authority to local governments or specially created tax districts. In the absence of specifically delegated taxing authority, local government may not levy any tax levied by the State.

\subsubsection{Legislative Procedures. The General Assembly may enact two} forms of legislation: bills and resolutions. Bills are the most common form of legislation. When approved by the General Assembly they become acts, and when signed by the Governor they become laws. Resolutions are formal expressions of the opinions and wishes of. the General Assembly, and do not require the approval of the Governor.

\subsubsection{Organization of the Senate. The membership of the Senate} consists of 18 Republicans and 15 Democrats following the 1980 election. In the 113th Ohio General Assembly (1979-80), there were 18 Democrats and 15 Republicans. Ohio State Senators are elected from districts consisting of three contiguous House districts. Figure 4-3 shows current Senate districts. Table 4-3 provides information concerning members of each district.

Until January 1, 1979 the Lieutenant Governor was presiding officer of the Senate. That constitutional provision was repealed on that date. The Senate now elects all of its leaders, with the majority party selecting the President and President Pro Tempore. The President of the Senate presides over the Senate, appoints members to the Committee on Committees which chooses committee members and chairmen, and signs all bills passed by the Senate. He is now the leader of the majority party in the Senate. The majority party also selects an Assistant President Pro Tempore 5 to assist the President and President Pro Tempore in their party duties. The minority party chooses a minority leader, assistant minority leader, and minority 


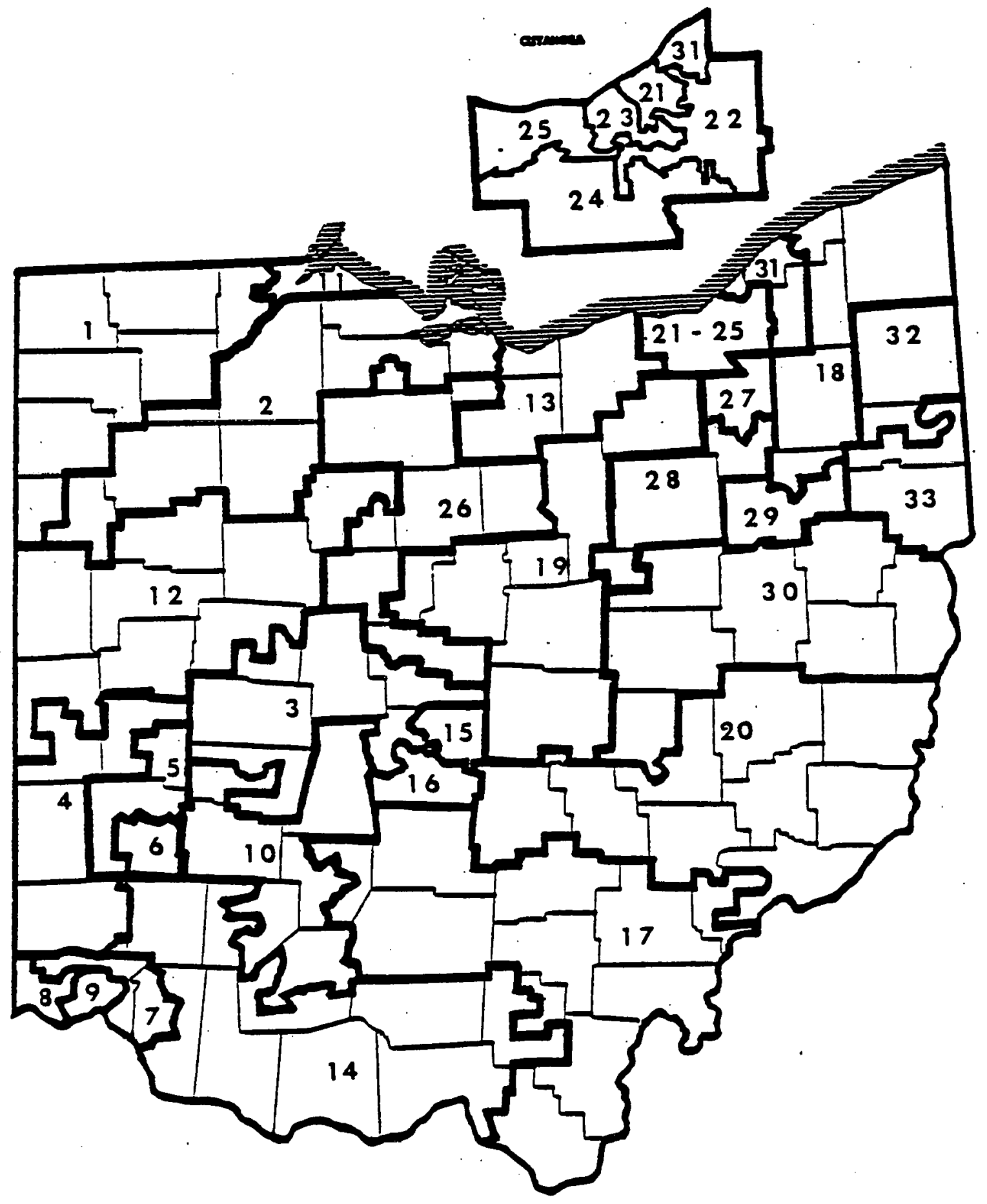

Figure 4.3. Ohio Senate Districts as Apportioned by the Governor, the Auditor of State and the Secretary of State for the Remaining Years or the Current Decennium.

Source: Synergic Resources Corporation 
TABLE 4-3. OHIO STATE SENATORS 1981-1982

Names and Addresses of Members of State Senate 114th General Assembly

\section{FIRST DISTRICT}

M. Ben Gaeth

340 Sunset Drive

Defiance 43512

SECOND DISTRICT

Paul E. Gillmor

2253 Sand Road

Port Clinton 43452

THIRD DISTRICT

Theodore M. Gray

942 Thomas Road

Columbus 43212

FOURTH DISTRICT

Donald E. Lukens

1066 East Park Lane

Middle town 45042

FIFTH DISTRICT

Neal F. Zimmers, Jr. 4120-E Camargo Drive

Dayton 45415

SIXTII DISTRICT

Charles J. Curran

56 Constantia Avenue

Dayton 45419

SEVENTH DISTRICT

Richard Finan

3068 Stanwin

Cincinnati 45241

EIGHTH DISTRICI

Stanley J. Aronoff

220 Wyoming Avenue

Cincinnati 45215

NINTH DISTRICT

William F. Bowen

3970 Dickson Avenue

Cincinnati 45229

TENTH DISTRICT

Michael DeWine

2587 Conley Road

Cedarville 45314

ELEVENTH DISTRICI

Marigene Valiquette

3211 Parkwood

Toledo 43610

\section{TWELFTH DISTRICT}

Rep.

Richard L。 Ditto

711 Wildwood Drive

Rep.

Elida 45807

THIRTEENTH DISTRICT

Rep. Ronald L. Nabakowskj

1014 West 11 th. Street

Lorain 44052

FOURTEENTH DISTRICT

Rep.

Cooper Snyder

10831 Watkins Bowman Rd. Rep. Blanchester 45107

\section{FIFTEENTH DISTRICT}

Rep.

John R. Kasich

2045 Hampstead Drive

Columbus 43229

SIXTEENTH DISTRICT

Dem.

Michael Schwarzwalder

250 East 19 th 'Avenue

Columbus 43201

SEVINTEENTH DISTRICT

Dem.

Oakley C. Collins

1005 Kemp Lane

Ironton 45638

EIGHTEENTH DISTRICT

Rep.

Mareus A. Roberto

3377 Summit Road

Ravenna 44260

NINETEENTH DISTRICT

Rep.

Thomas A. Van Meter

1028 Country Club Lane

Ashland 44805

TWENTIETH DISTRICT

Dem.

Sam Speck

R.D. 2, Box 79

New Concord 43762

TWENTY-FIRST DISTRICT

Rep.

M“ Morris Jackson

1723 East 70 th Street

Cleveland 44103

Rep.

Den. . .

Rep.

TWENTY-SECOND DISTRICT

Ben M. Skall

2202 Acacia Park Drive

Rep. 
TWENTY - THIRD DISTRICT

Charles L. Butts Dell. 4514 Franklin Blvd. Cleveland 44102

THENTY-FOURTH DISTRICT

Gary C. Suhadolnik Rep. 9313 Roxbury Road Parma Heights 44130

TWENTY-FIFTH DISTRICT

Paul R. Matia Rep.
2000 King James Parkway Westlake 44145

TWENTY-SIXTH DISTRICT

Paul E. Pfeifer

3234 Kiess Road

Bucyrus 44820

TWENTY-SEVENTH DISTRICT

O1iver Ocasek 7665 North Gannett Road Northfield 44067

Dem.

TWENTY-EIGHTH DISTRICT

Renneth R. Cox 668 East Park Avenue Barberton 44203

Dem.
TWENTY-NINTH DISTRICT

Thomas F. Walsh Rep. 6575 Kennebuck Cir., N.W. Canton 44718

\section{THIRTIETH DISTRICT}

Bill Ress

168 Tuscora Avenue, N.W.

New Philadelphia 44663

THIRTY-FIRST DISTRICT

J. Timothy McCormack Dem. 170 East 209 th Street Euclid 44123

THIRTY-SECOND DISTRICT

Thomas E. Carney Dem.

935 North Ward

Girard 44420

THIRTY - THIRD DISTRICT

Harry Meshe 1

786 Fairgreen Avenue

Dem.

Youngstown 44510 
whip: Both the majority and minority leaders have prime responsibility for developing their party's position on legislative proposals. The leaders of both parties use their party caucus as a device for establishing their party's position and developing party unity. 6

Presently, the officers of the Senate are:

- President: Paul E. Gillmor (R-2nd district).

- President Pro Tempore: Thomas A. Van Meter (R-19th district).

- Assistant President Pro Tempore: Stanley J. Aronoff (R-8th district).

- Minority Leader: Harry Meshel (D-33rd district).

- Assistant Minority Leader: Neal F. Zimmers, Jr. (D-5th district).

- Minority Whip: Charles L. Butts (D-23rd district).

- Minority Floor Leader: Timothy J. McCormack (D-31st district).

The most active type of committee is the standing committee and any subcommittees that may be designated. During the 113th General Assembly (1979-80), there were 12 standing committees in the Senate. Among the standing committees relevant to low-level radioactive wastes are: Agriculture; Conservation and Environment; Education and Health; Energy and Public Utilities; Finance; and Highways and Transportation.

4.2.3.5 Organization of the House of Representatives. The membership of the House of Representatives consists of 56 Democrats and 43 Republicans following the 1980 election. In the 113th General Assembly (1979-80) there were 62 Democrats and 37 Republicans. Members of the House are elected from 99 districts, which must be relatively equal in population, compact, and composed of contiguous territory. Figure 4-4 shows current House districts. Table 4-4 provides information about the members of each district. 


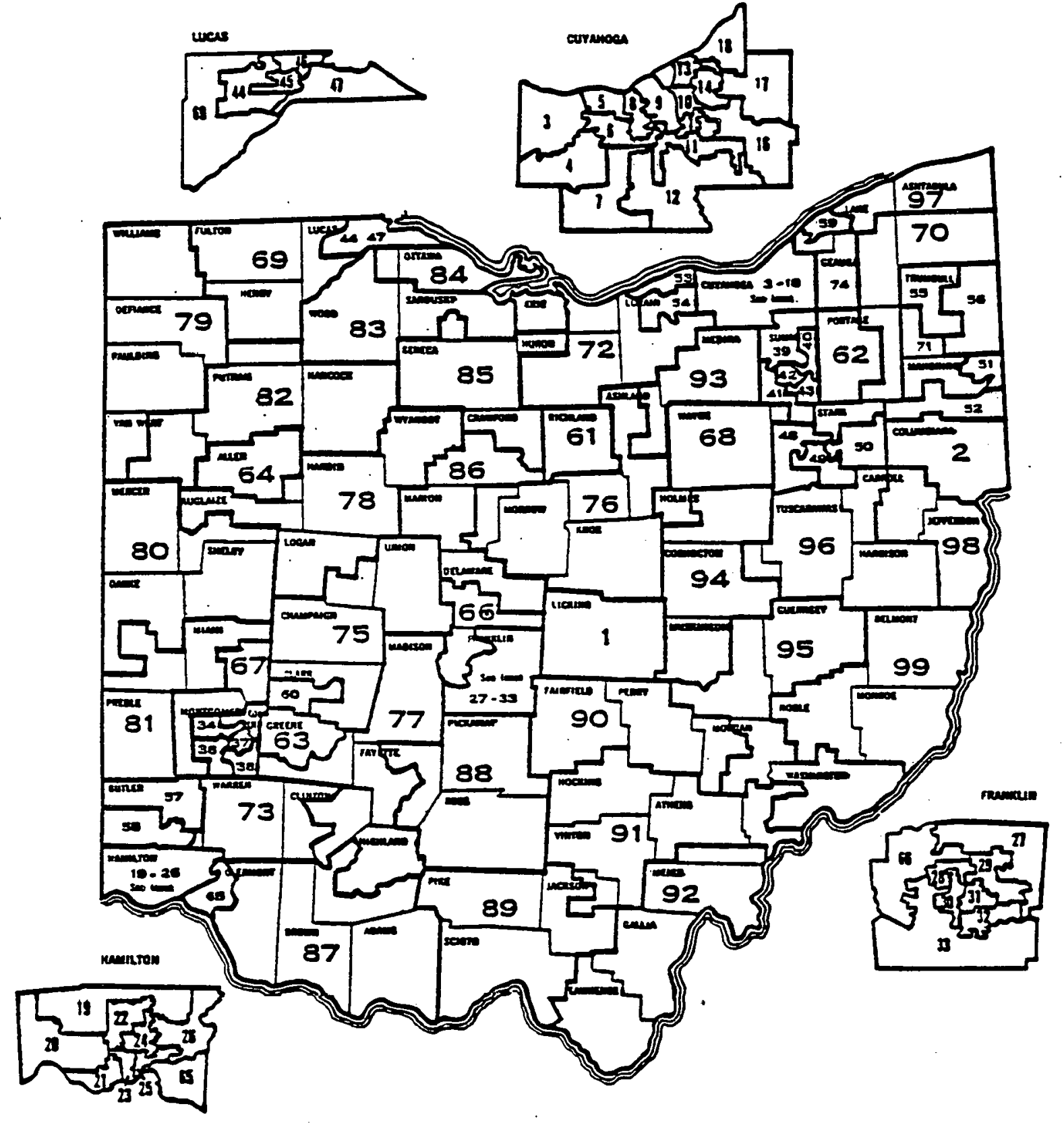

Figure 4.4. Ohio House of Representatives Districts as Apportioned by the Governor, the Auditor of state and the Secretary of State for the Remaining Years of the Current Decennium.

Source: Synergic Resources Corporation. Primary data from Ohio Secretary of State's Office. 
TABLE 4-4. OHIO STATE REPRESENTATIVES 1981-1982

Names and Addresses of the Members of the Ohio

House of Representatives - 114th General Assembly

EIRST DISTRICT

Eugene Branstool
6360 Johnstown-Utica Rd.
Utica 43080
SECOND DISTRICT

John P. Wargo Dem.

344 East Chestnut Street

Lisbon 44432

THIRD DISTRICT

James M. Petro

315 Falmouth Drive

Rocky River 44116

FOURTH DISTRICT

Roceo J. Colonna

14431 Parkman Blvd.

Brook Park 44142

EIFTH DISTRICT

Francine M. Panehal

11502 Edgewater Drive

Cleveland 44102

SIXTH DISTRICT

Patioid A. Sweoney

15277 Trisketr Road

Cleveland 44111

\section{SEVENTH DISTRICT.}

Kenneth A. Rocco

12912 List Lane

Parma 44130

EIGHTH DISTRICI

Benny Bonanno

3311 Marvin Avenue

Cleveland 44109

\section{NINTH DISTRICT}

Troy Lee James

2177 East 43 Street

Cleveland 44103

\section{TENTH DISTRICT}

Thomas $M$. Bell

2941 East Boulevard

Cleveland 44104

\section{ELEVENTH DISTRICT}

Frank Mahnic, Jr. 11019 Plymouth Avenue Garfield Heights 44125

Dem.

Dem.

Dem.

Dem.

\section{TWELFTH DISTRICT}

Donna Pope

3915 Longwood Avenue

Rep.

Parma 44134

\section{THIRTEENTH DISTRICT}

Ike Thompson

899 East 128 Street

Cleveland 44108

\section{FOURTEENTH DISTRICT}

Mary 0. Boyle Dem.

1285 Inglewood Drive

Cleveland Heights 44121

\section{FIFTEENTH DISTRICT}

John D. Thompson, Jr. Dem.

15611 Stockbridge Avenue

Cleveland 44128

\section{SIXTEENTH DISTRICT}

Lee I. Fisher

3286 Enderby Road

Dem.

Shaker Heights 44120

SEVENTEENTH DISTRICT

Matthow J. Hatcliadutials Rep. 1018 Woodlane Drive Mayfield Village 44143

\section{EIGHTEENTH DISTRICT}

Ronald J. Suster

Dem .

2111 Aberdeen Drive

Euclid 44143

NINETEENTH DISTRICT

Dale N. Van Vyren

4799 Eields-Ertel Road

Rep.

Cincinnati $4524 I$

TWENT IETH DISTRICT

Thomas A. Pottenger

2038 Danville Drive

Rep.

Cincinnati 45238

TWENTY-FIRST DISTRICT

Jerome F. Luebbers

5490 Betiin Court

Cincinnati 45238

TWENTY - SECOND DISTRICT

Edith P. Mayer Rep.

10120 Winstead Lane

Cincinnati 45231
Dem. 
TWENTY-THIRD DISTRICT

William L. Mallory

907 Dayton Street

Cincinnati 45214

TWENTY-FOURTH DISTRICT

Terry M. Tranter

7303 Fair Oaks Drive

Cincinnati 45237

TWENTY-FIFTH DISTRICT

Helen Rankin

3461 Evanston Avenue

Cincimati $\mathbf{4 5 2 0 7}$

TWENTY-SIXTH DISTRICT

Helen H. Fix

3141 Es ther Drive

Cincinnati 45213

TWENTY-SEVENTH DISTRICT

Jo Ann Davidson

6870 Livingston Ave

Reynoldsburg 43068

TWENTY-EIGHTH DISTRICT

Dana A. Deshler, Jr. Rep.

2605 York Road

Columbus 43221

TWENTY-NINTH DISTRICT

Les Brown

3211 East Hudson Street

Columbus 43219

THIRTIETH DISTRICT

Mike Stinziano

314 King Avenue

Columbus 43201

THIRTY-FIRST DISTRICI

Otto Beatty, Ir.

380 South Fifth Street

Columbus 43215

THIRTY-SECOND DISTRICT

Dean Conley Dem.

5125 "I" Stone Ridge Drive

Columbus : 43213

THIRTY-THIRD DISTRICT

Don E. Gilmore

3131 Mary Avenue

Columbus 43204

THIRTY-FOURTH DISTRICT

Edward J. Orlett

3 Cambridge Avenue

Dayton 45406

Dem.

Dem.

Dem.

Dem.
THIRTY-FIFTH DISTRICT

Tom Fries

4120-F Camargo Drive

Dayton 45415

THIRTY-SIXTH DISTRICT

Dem. C. J. McLin, Jr. Dem.

1130 Germantown Street

Dayton 45408

THIRTY-SEVENTH DISTRICT

Larry V. Ballweg

45 East Dixon Avenue

Rep :

Dayton 45419

THIRTY-EIGHTH DISTRICT

Rep.' Robert L. Corbin Rep:

135 Shadybrook Drive

Dayton 45459

THIRTY-NINTH DISTRICT

Vernon F. Cook Dem.

3395 Purdue Street

Cuyahoga Falls 44221

FORTIETH DISTRICT

Thomas C. Sawyer 1298 North Howard Street Akron 44310

FORTY-FIRST DISTRICI

Robert D. Netrle
31 - 3Ist Street, S.W. Barberton 44203

Dem.

FORTY-SECOND DISTRICT

Pete Crossland

29 Burtun Avenue

Akron 44302

FORTY - THIRD DISTRICT

Cliff Skeen

3255 Carper Avenue

Akron 44312

FORTY-FOURTH DISTRICT

David L. Karmol.

3642 Garrison Road

Toledo 43613

FORTY - FIFTH DISTRICT

Rep.

Casey C. Jones

Dem.

355 Pinewood Avenue

Toledo 43602

FORTY -SIXTH DISTRICT

Dem.

Arthur Wilkowski

546 East Lake Street

Dem.

Dem .

Dem.

Dem.

Rep.

Toledo 43608 
FORTY -SEYENTH DISTRICT

Barney Quilter.

641 Woodville Road

Toledo 43605

FORTY-EIGHTH DISTRICT

Richard F. Maier

1222 Providence, N.E.

Massillon 44646

FORTY-NINTH DISTRICT

Charles Red Ash

21039 Street, S.W.

Canton 44706

FIFTIETH DISTRICT

William J. Healy 1211 Havana Place, N.E. Canton 44714

FIFTY-FIRST DISTRICT

Thomas P. Gilmartin Dem. 825 South Hazelwood Avenue Youngstown 44509

FIFTY-SECOND DISTRICT.

Joseph J. Vukovich, III Dem. 6322 A CJingan Road

poland 44514

FIFTY-THIRD DISTRICT

J. Leonard Camera 1147 Tenth Street

Lorain 44052

FIFTY-FOURTH DISTRICT

Marguerite E. Bowman Rep.

1416 Ford Road

EIyria 44035

FIFTY-FIFTH DISTRICT

Robert A. Nader

798 Wildwood, N.E.

Warren 44483

FIFIY-SIXTH DISTRICT

Joseph P. Williams

888 Hartzell

Niles 44446

FIFTY-SEVENTH DISTRICT

William Donham

113 Lylburn Road

Middletown 45042

FIFTY-EIGHTH DISTRICT

Hichael A. Fox

5881 Fairham Road

Hamilton 45011

Dem.

Rep.

Rep.

Dem.

Rep.
FIFTY-NINTH DISTRICT

Edward J. Hughes

8241 Starburst Drive

Dem.

Mentor 44060

SIXTIETH DISTRICT

David Hartley

1715 Prospect Street

Dem. Springfield 45503

SIXIY-FIRST DISTRICT

Sherrod Brown

74 Parkwood Boulevard

Mansfield 44906

SIXTY-SECOND DISTRICT

John A. Begula Dem.

P.O. 446

Kent 44240

SIXTY-THIRD DISTRICT

James S. Zehner

418 North Park Place

Yellow Springs $\mathbf{4 5 3 8 7}$

SIXTY - FOURTH D.ISTRICT

Waldo Bennett Rose

1602 West Market Street

Lima 45805

SIXIY-FIFTH DISTRICT

John O'Brien

7651 Burlinehills

Cincinnati 45244

SIXTY-SIXTH DISTRICT

Rep. Lawrence E. Hughes Rep.

4319 Fairoaks Drive

Columbus 43214

SIXTY-SEVENTH DISTRICT

Dem. Russ Guerra, Jr.. Rep.

4601: Rachburn Drive

Englewood 45322

SIXTY-EIGHTH DISTRICT

Dem. Ronald D. Amstutz Rep. 626 Smithville Road Orrville 44667

\section{SIXTY-NINTH DISTRICT}

Rep. John A. Galbraith Rep.

602 Pierce Street

Maumee 45537

\section{SEVENTIETH DISTRICT}

Dave Johns on
514 Marquardt Avenue, N.E.

North Canton 44720 
TABIE 4-4.3 (Continued)

1. SEVENTY - FIRST DISTRICT

Thomas J. Carney

5200 W. Blvd.

Boardman 44512

SEVENTY-SECOND DISTRICT

Marie Tansey

1201 State Street

Vermilion $\mathbf{4 4 0 8 9}$

SEVENTY - THIRD DISTRICT

Corwin Nixon

1030 Kirby Road

Lebanon 45036

SEVENTY-FOURTH DISTRICT

Dennis L. Wojtanowski Dem.

14458 Stone Road

Newbury 44065

SEVENTY-EIFTH DISTRICT

Charles R. Saxbe

177 East Sandusy Street

Mechanicsburg 43044

SEVENTY-SIXTH DISTRICT

Harry E. Turner

404 East Vine Street

Mount Vernon $\mathbf{4 3 0 5 0}$

SEVENTY-SEVENTH DISTRICT

Joseph E. Haines

2750 E. Spring Val1ey-

Paintersvilie Rd.

Xenia 45385

SEVENTY-EIGHTH DISTRICT

Rod Hughes

Route 1

Huntsvil1e 43324

SEVENTY-NINTH DISTRICT

Larry W. Manahan

815 Jefferson Avenue

Defiance 43512

EIGHTIETH DISTRICT

Daie Locker

Box 356

Anna 45302

EIGHTY-FIRST DISTRICT

Robere E. Netzley

2750 Pemberton Road

Laura 45337

EIGHTY-SECOND DISTRICT

Michael G. Oxley

1995 Old Mill Road

Findlay 45840

Dem.

Rep.

Rep.
EIGHTY -THIRD DISTRICT

Robert E. Brown

503 West Front Street

Rep.

Perrysburg 43551

EIGHTY-FOURTH DISTRICT

Frederick H. Deering Dem.

9610 Ransom Road

Monroeville 44847

EIGHTY-FIFTH DISTRICT

Gene Damschroder Rep.

364 S. S.R. 53

Fremont 43420

EIGHTY-SIXTH DISTRICT

Walter D. MeClaskey 3454 Marion Marysville Road. Marion 43302

EIGATY-SEVENTH DISTRICT

Harry C. Malote Dem.

2526 St. Rt. 32

Mt。 Orab 45154

\section{EIGHTY-EIGHTH DISTRICT}

Myr1 H. Shoemaker

10479 Upper Twin Road

Dem .

Lyndon 45649

EITHTY-NINTH DISTRICT

Vernal G. Riffe, Jr.

703 Lakeview Avenue

New Boston 45662

NINETIETH DISTRICT

Steven 0 . Williams

1548 Lynn Drive

Lancaster 43130

Rep.

NINETY-FIRST DISTRICT

Claire M. Ball, Jr.

Rep.

48 Eden Place

Athens 45701

NINETY - SECOND DISTRICT

Ronald H. James

Route 2, Box 195

Dem.

Proctorville 45669

NINETY - THIRD DISTRICT

William G. Batchelder Rep.

Rep. 435 East Smith Road

Medina 44256

NINETY-FOURTH DISTRICT

Rep. James R. Ross Rep.

1629 Sleepy Hollow Drive

Coshocton 43812 
TABLE 4-4.4 (Continued)

NINETY-FIFTH DISTRICT

Tom Johnson

Route 1, Skyline Drive

Cambridge 43725

NINETY-SIXTH DISTRICT

William E. Hinig

120 Prysi Parkway

New Philadelphia 44663

NINETY - SEVENTH DISTRICT

Robert J. Boggs

316 Kathleen Drive

Jefferson 44047

\section{NINETY-EIGHTH DISTRICT}

Rep. Arthur R. Bowers Dem.

Eft's Lane

Steubenville 43952

NINETY-NINTH DISTRICT

Dem.

Robert William Ney

1409 Maple Avenue

Bellaite 43906
Rep.

Dem.

Source: Ohio Legislative Directory 
The membership of the House of Representatives elects by majority vote a Speaker, a Speaker Pro Tempore, a majority floor leader, an assistant majority floor leader, a minority leader, an assistant minority leader, and majority and minority whips. The Speaker and Speaker Pro Tempore are officers of the House. The Speaker presides, signs all legislation approved by the chamber, serves as an ex-officio member of committees, and selects committee members and chairmen. The Speaker Pro Tempore performs the duties of the Speaker in his absence and assists the Speaker in performing his duties.

As in the Senate, the eleoted leaders also serve as party leaders in formulating party positions on legislative matters. The leaders of both parties use, the party caucus as a device for establishing their party's position and developing party unity. 7

Presently, the officers of the House of Representatives are:

- Speaker: Vernal G. Riffe (D-New Boston).

- Speaker Pro Tempore: Barney Quilter (D-Toledo).

- Majority Floor Leader: William L. Mallory (D-Cincinnati).

- Assistant Majority Floor Leader: Vernon F. Cook (D-Cuyahoga Falls).

- Majurilty Leader: Corwin M. Nixon (R-Lebanon).

- Assistant Minority Leader: Waldo Bennett Rose (R-Lima).

- Minority Whip: Helen H. Fix (R-Cincinnati).

As in the Senate, all detailed legislative work in the House is performed in committee. With its larger size, the House is more dependent upon its committees than is the Senate. The House standing committees are the primary arenas of detailed legislative review. 8 
During the 113th General Assembly (1979-80) there were 22 standing committees in the House of Representatives: Among the standing committees relevant to low-level radioactive wastes are Agriculture and Natural Resources, Energy and Environment, Finance-Appropriations, Highways and Highway Safety, Interstate Cooperation, and Public Utilities.

4.2.3.6 Political Parties. Within both chambers of the General Assembly, the political party has been the major tool for organization and development of legislative proposals. Leadership within each chamber is chosen by the parties and issues are structured through party competition. However, inter-party conflict has generally been avoided through informal cooperation. Membership on standing committees is allocated according to each party's proportion of total membership, and committee chairmen are usually members of the majority party. Within each party and each chamber, the party caucus has been the major organizational structure of the legislative process.

\subsubsection{Judicial Branch}

There are two classes of courts in Ohio: the constitutional courts, established by the Constitution, and the legislative courts, established by the General Assembly. The Ohio constitutional courts include the Common Pleas Court, the Court of Appeals, and the Supreme Court. The legislative courts include municipal courts, county courts, and mayors' courts. 9

\subsubsection{Local Government}

The structure of Ohio local government is typical of Midwestern States, having counties, municipalities, townships, school districts, and special districts. Ohio maintains a tradition of relatively strong local government, with heavy reliance upon local authorities for the delivery of services. 10 
The basic unit of rural government in Ohio has been the township which now exists for administrative purposes only. Townships and their trustees still retain responsibilities for zoning, township roads, taxes, and other township services.

County government remains strong in rural areas of Ohio. County government is also created as an administrative agent of the state, unlike municipalities. There are 88 counties in Ohio, each of which elects a three-member board of county commissioners and a variety (usually nine) of administrative officials. County government maintains responsibility for public works, sanitation, public welfare, law enforcement, finance, and recording. Counties in Ohio have-increasingly assumed responsibilities for waste disposal services. Although counties may select home rule, few counties have opted to do so due to public resistance to the changes in government structure that would be required. 11

There are two types of municipalities in Ohio: villages, which are those under 5,000 population; and cities, which are those with populations of 5,000 or more. Both types of municipalities may adopt home rule charters or operate under a general statutory plan. Most have opted for some variation of the latter: mayor-council, commission, or council-manager options. All municipalities provide five major types of services: finance, public services (including streets, water, sewage, garbage, and rubbish), safety, welfare, and law. A major function of municipal government is the zoning of the municipality into districts for varlous approved uses (primarily residential, commercial, or industrial).

Local government remains strong in Ohio, despite trends toward the centralization of government services elsewhere. County and township governments, though created for a largely rural society, continue to be important elements for the delivery of public services. Despite large numbers of metropolitan areas with critical urban problems, there has been little movement in Ohio toward metropolitan forms of government. Although cooperation in the delivery of special services such as airports, waste disposal, and water has grown, there has been little movement toward regional reforms of government. 
1. Michael Barone, et. al., The Almanac of American Politics 1980 (New York: E. P. Dutton, 1979), p. 674 .

2. Ibid, p. 673 .

3. Although there are approximately 80 subcommittees in the Congress that have some potential relationship to issues involving low-level radioactive waste, there are seven major committees that share responsibility for this area. In the House, the Committees are Science and Technology, Interstate and Foreign Commerce, Government Operations, and Interior and Insular Affairs. In the Senate, the Committees are Energy and Natural Resources, Governmental Affairs, and Environment and Public Works.

4. Joseph A. Schlesinger, "A Comparison of the Relative Positions of Governors," in Thad Beyle and J. Oliver Williams, The American Governor in Behavioral Perspective. (New York: Harper and Row, 1972), pp. 141150 .

5. A Guidebook for Ohio Legislators, p. 83 .

6. Ibid, $\mathrm{pp} \cdot 22-25$.

7. Ibid, pp. 50-51.

8. IVId, 9.84 .

9. John J. Gargan and James G. Coke, "An Overview of the Ohio Political System," in Political Behavior and Public Issues in Ohio, ed. John J. Gargan and James G. Coke (Kent State University Press, 1972), pp. 5051.

10. Rose, Ohio Government, p. 63.

11. Ibid, p. 167-168. 


\section{A REVIEW OF STATE LOW-LEVEL WASTE MANAGEMENT POLICY: PRESENT AND PROPOSED}

\subsection{Overview}

Ohio has a substantial body of legislation dealing with low-level radioactive waste. The governmental authority established by this legislation tends to be diffused among State agencies.

What follows is a review of relevant Ohio legislation, both present and proposed, which gives an indication of radioactive waste management policy in Ohio. Appendix B contains the full text of relevant onio statutes pertaining to low-level waste management concerns.

\subsection{Existing Nuclear Waste Management Policy In Onio}

\subsubsection{Ohio Revised Code, Chapter 107.14}

This section authorizes the Governor of Ohio to accomplish the transfer of authority from the Federal Government to the State of Ohio regarding certain peaceful uses of atomic energy.

\subsubsection{Ohio Revised Code, Chapter 122: Department of Economic and Community} Development: Sections 122.13 - 122.16: Midwest Nuclear Compact

This act provides the authority for the State of ohio to enter into an agreement with some or all of twelve other Midwest States* in order to form a Midwest Nuclear Compact. The Board may contain one member from each State, as well as a non-voting representative of the Federal Government. The Director of Economic and Community Development is designated as the representative of the State of ohio.

* Article IX specifies that eligible parties to the compact may include the States of Illinois, Indiana, Iowa, Kansas, Kentucky, Michigan, Minnesota, Missouri, Nebraska, North Dakota, South Dakota, and Wisconsin. 
Pertinent powers and duties of the Board as specified in Article $V$ of the compact include:

- To study standards, laws, codes, rules, regulations, and administrative practices in or related to nuclear fields.

- To conduct ongoing analysis of the position of party States regarding evolving nuclear and related technologies.

- To encourage the development and use of scientific advances and discoveries in nuclear facilities, energy, materials, products, and by products.

- To undertake non-regulatory functions with respect to non-nuclear sources of radiation.

- To recommend amendments or additions to the laws, codes, rules; regulations or administrative procedures and practices or local laws or ordinances of member States or their subdivisions in nuclear and related fields.

- To make recommendations which would facilitate the transport of nuclear equipment, materials, products, by-products, wastes, and any other related substances in order to make their availability or disposal feasible.

- To make recommendations regarding liability incurred during any aspect of operations in nuclear or related fields.

- To coordinate nuclear incident prevention and control plans of each party state.

The Midwest Nuclear Compact never operated as a functioning organization due to the fact that Federal legislative authorization was never received. 


\subsubsection{Ohio Revised. Code, Chapter 3701.33-.34: Public Health Council}

This law authorizes the creation of a seven member Public Health Council, appointed by the Governor. This council sits as an autonomous, rule-making body overseeing the Department of Health.

The council is empowered to:

- Make and amend the sanitary code.

- Hear appeals to administrative decisions of the Director of Health.

- Conduct such public hearings as specified by law.

- Prescribe the organization and functions of the Department of Health and its divisions, including the Bureau of Radiation Control.

- Consider any matter related to the preservation and improvement of public health in Ohio.

\subsubsection{Ohio Revised Code, Chapter 3701.4: Radiation Control}

This chapter is known as the radiation protection statute, delineating the functions, powers, and duties of the Puhlic Health Council and the Department of Health regarding the prevention and prohibition of improper radiation (as defined in Section 3701.90 (E), improper radiation).

The Public Health Council is empowered to adopt regulations in order to identify, prohibit, and prevent improper radiation as well as require registration with the Director of Health of those using, producing, storing, or disposing of radioactive materials.

Enforcement of Sections 3701.90-.99 and any administrative regulations promulgated pursuant to these sections is delegated to the Director of Health. Additionally, the Director of Health is expected to: 
- Develop comprehensive policies and programs to monitor improper radiation.

- Advise, consult, and cooperate with other Federal and interstate agencies.

- Research related. issues.

- Disseminate radiation protection information.

- Review plans for radiation control.

- Register users of radioactive materials and inspect radiation sources.

- Require maintenance of records.

- Insure compliance with radiation protection rules and regulations.

The Director of Health specifically is empowered to issue, modify, or revoke orders so as to prohibit or abate "the discharge of radioactive material or waste into the ground, air, or waters of the state."

Section 3701.93 stipulates the appointment of a Radiation Advisory Council, consisting of five members appointed by the Director of Health, to review and recommend policies affecting the administration and enforcement of Sections 3701.90-.99.

\subsubsection{Ohio Revised Code, Chapter 4163: Atomic Energy}

These sections primarily relate to the use and possession of radioactive substances. Section 4163.02 prohibits the production or possession of nuclear material without an NRC and/or State issued license. 
Seven departments of the State are required to conduct studies and recommend laws in order to carry out this act: the Departments of Health, Industrial Relations, Transportation, Insurance, and Natural Resources as well as the Industrial Commission and the Public Utilities Commission. The Governor may direct other State departments or agencies to conduct similar investigations.

Enacted in 1980, Section 4163.07 requires written notification prior to the transport of nuclear material into Ohio. Notification is to be made to the Director of the Disaster Services Agency who, in turn, alerts the Directors of Highway Safety and Environmental Protection, the Chairman of the Public Utilities Commission, and the Sheriff of each county along proposed and alternate shipping routes.

\subsubsection{Ohio Revised Code, Chapter 6121: Water Development Authority}

This chapter mandates the creation of the seven member Ohio Water Development Authority. The Directors of the Environmental Protection Agency and the Department of Natural Resources sit as ex-officio members in addition to five members appointed by the Governor with the advice and consent of the Senate.

This autonomous authority receives broad powers to initiate and implement water quality projects, including the right to issue water development revenue bonds and notes of the State (see Section 6121.06).

The Director of the Ohio Environmental Protection Agency sets water quality standards on behalf of the Water Development Authority.

This chapter authorizes water projects to alleviate existing or potential pollution from a number of sources, including industrial wastes. Section 6121.01, Definitions, defines industrial waste to be:

"any liquid, gaseous, or solid waste substance, heat, radioactivity or radiation, resulting from any process of industry, manufacture, trade, or business, or from the 
development, processing, or recovery of any natural resource ... which pollutes the waters of the state, or which in the absence of a waste water facility would pollute or cause greater pollution of the waters of the State" (Emphasis Added).

\subsubsection{Ohio Revised Code, Chapter 6123: Solid Waste Projects}

Similar to the preceding legislation, this chapter specifically empowers the Ohio Water Development Authority to (among other things) "acquire, construct, reconstruct, enlarge, improve, furnish, equip, maintain, repair, operate, lease or rent to, or contract for operation by, a person or governmental agency, solid waste projects, and establish rules and regulations for the use of such projects (Section 6123.04CD)n. The authority is empowered to issue solid waste revenue bonds to fund solid waste projects.

For purposes of this chapter, solid waste is defined as:

"unwanted residual solid or semi-solid material as results from industrial operations, including those of public utility companies, and commercial, :distribution, research, agricultural, and community operations, including garbage, combustible, noncombustible or radioactive material, street dirt, and debris (Section 6123.01(c))" (Emphasis Added).

Included in the definition of solid waste facilities are facilities or property for the storage or final disposal of low-level radioactive wastes.

\subsubsection{Ohio Administrative Code, Radiation Protection Rules 3701-38-23 to 3701-38-29 of the Ohio Radiation Protection Standards}

These rules stipulate certain standards, procedures, and prohibitions regarding the storage and disposal of radioactive material. 
Disposal may be accomplished only by transfer to another entity with the approval of the Director of Health, pursuant to application procedures (specified by Rule 3701-38-26). Rules are excluded for disposal by three methods: 1) by release into sanitary sewerage systems; 2) by burial in the soil; and 3) by incineration.

\subsubsection{State of Ohio, Memorandum of Understanding: "Response to Hazardous Materials -Incidents"}

This memorandum was entered into in June 1980 in order to coordinate State agency functions concerning the response to incidents involving hazardous materials, including radioactive substances. The Disaster Services Agency assumes the primary role for coordinating activites of other State agencies in the case of incidents involving radioactive materials.

\subsubsection{Amended Senate B111 No. 208}

As discussed earlier in this section, this bill supplements the Ohio Revised Code, Chapter 4163: Atomic Energy. This act was a response to anticipated waste shipments through Ohio from the disabled TMI facility. This bill requires advance notification of the transport of nuclear materials into and through the State of Ohio. Senate Bill No. 208 became effective July 18, 1980.

\subsubsection{Amended House Joint Resolution 27}

Adopted June 26, 1979, this resolution appointed a joint committee to study the disposal of hazardous and nuclear wastes in Ohio in order to determine "what persons, corporations, or governmental entities currently regulate these procedures, and recommend any changes that are needed to establish the most effective disposal procedures." 
The committee subsequently met and completed the portion of the mandated study on chemical wastes. The nuclear waste portion was not addressed prior to the termination of the 113th Ohio General Assembly. As of January 1, 1981, it is not known if the study committee will be reappointed when the General Assembly reconvenes.

\subsubsection{Low-level Radioactive Waste Management in Ohio: Summary of Legislative and Administrative Mandates}

As evidenced by the passage of Amended House Joint Resolution 27 (1979), authority for radioactive waste management in Ohio is dispersed among several agencies. Regulation of harmful radiation is lodged with the Public Health Council and its enforcement arm, the Ohio Department of Health. The Director of the Department of Health and the Radiation Advisory Council are charged to develop radiation monitoring programs associated with the use, possession, transport, storage and disposal of radioactive materials, pursuant to Section 3701.92 CB of the Ohio Revised Code.

The Disaster. 3ervices Agency has been designated the lead agency during any emergency or disaster situation involving radioactive materials (see Appendix B). The Departments of Health and Transportation and the Environmental Protection Agency provide support services in the case of nuclear accidents.

At the same time, the Ohio Revised Code, Chapter 4163; Atomic Energy, specifies that the following State departments are empowered to conduct studies and recommend laws necessary to ensure compliance with Chapter 4163:

- Department of Health.

- Department of Industrial Relations. 
- Industrial Commission.

- Department of Transportation.

- Public Health Council.

- Department of Insurance.

- Department of Natural Resources.

- Any other department or agency "as the governor may direct and for purposes specified by him".

While the Department of Health monitors the long-term health effects of radioactive substances in Ohio, the Environmental Protection Agency seeks to develop programs to ensure that nuclear activities in Ohio are carried out in an environmentally acceptable manner (see Appendix B, . "Nuclear Waste in Ohio: A Status Report). Enforcement of such programs is, however, the province of the Department of Health.

Authority to acquire, construct, fund, and operate disposal sites for radioactive wastes is vested with the Ohio Water Development Authority. The Directors of the Environmental Protection Agency, the Department of Natural Resources, and the Department of Energy sit as ex-officio members of the autonomous Water Development Authority.

The Water Development Authority may issue revenue bonds to finance public or private waste water or solid waste facility projects, as mentioned earlier. Such projects must alleviate pollution resulting from industrial or solid wastes. The definitions sections of Chapter 6121 and 6123, Water Development Authority law, specifically allude to radioactive wastes. No attempts to initiate waste projects in Ohio under the provisions of Chapters 
6121 and 6123 were documented. It should be noted that, although the Water Development Authority enjoys rather broad and autonomous powers to initiate and conduct waste facility projects, any projects initiated by the Authority but developed privately would be subject to local zoning restrictions (where they exist) in the State of Ohio.

Regarding interstate compacts or agreements, since 1971 the State of Ohio has authorized participation in an agency known as the Midwest Nuclear Board. Enabling legislation names the Director of the Ohio Department of Economic and Community Development as the State's representative on the proposed board.

Although a requisite number of States ratified the proposed Midwest Nuclear Compact, the Measure was not enacted by Congress. Nevertheless, the Ohio Revised Code, Sections 122.13-122.16, contain Ohio's original ratification of and amendments to the Midwest Nuclear Compact as precedent for similar future agreements.

Discussions are underway on regional solutions for low-level radioactive waste management. The Ohio Environmental Protection Agency is the State's lead agency in this matter, involving representatives of the States of Illinois, Wisconsin, Michigan, Indiana, and Ohio.

Ohio remains a "non-agreement state". Since adoption of Chapter 107.14 of the Ohio Revised Code (authorizing the Governor to implement agreement status proceedings), Governors of both parties have chosen not to enter into agreement status. While there is no indication that the State of Ohio may choose to assume management of existing and future disposal sites within its boundaries, three factors may result in greater specification of low-level waste policies and procedures: State approval of investigations conducted on behalf of the Midwest Task Force on Low-level Waste Management; the creation of a Midwest Regional Compact; and the possibility of gubernatorial reappointment of a joint committee to study nuclear wastes authority in Ohio, pursuant to Amended Joint Resolution 27 (1979); and the proposed reorganization of the Ohio Environmental Protection Agency. 
Ohio remains a "non-agreement state". Since adoption of Chapter 107.14 of the Ohio Revised Code (authorizing the Governor to implement agreement status proceedings), Governors of both parties have chosen not to enter the agreement status. While there is no indication that the State of Ohio may choose to assume management of existing and future disposal sites within its boundaries, three factors may result in greater specification of low-level waste policies and procedures: State approval of investigations conducted on behalf of the Midwest Task Force on Low-level Waste Management; the creation of a Midwest Regional Compact; and the possibility of gubernatorial reappointment of a joint committee to study nuclear wastes authority in Ohio, pursuant to Amended Joint Resolution 27 (1979); and the proposed reorganization of the Ohio Environmental Protection Agency. 


\section{INTEREST GROUPS}

\subsection{Introduction}

When considering policy options, it is advantageous for decision-makers to know the public's view of different options. As a technical issue, low-level radioactive waste disposal crosses the threshold of public awareness infrequently*, and therefore the public will probably have little understanding and no easily defined opinions on the issue. Certain interest groups, however, may consider low-level radioactive waste as a relevant policy issue due to its potential impacts upon the set of values or economic concerns which they represent.

A survey was designed to solicit information regarding the membership, contact individual, current telephone numbers, etc., for those groups which would possibly have an interest in low-level radioactive waste management. Listed below are those organizations that have both a defined constituency and a potential interest in low-level radioactive waste activities affecting Ohio. Unless otherwise noted, all groups have a statewide constituency.

Environmental organizations appear to be represented in larger numbers, since these organizations are public interest in nature, often rely upon a voluntary staff, and respond to a broad spectrum of value-oriented environmental questions. Professional organizations, on the other hand, tend to have a single legislative lialson organization. Medical organizations are an example of this; there are a number of topical

*This assertion seems to be borne out by the media survey as discussed in Section 7 . 
professional organizations (internists, radiologists, etc.) which are primarily involved with internal information transfer. Actual legislative activity is usually left entirely to the American Medical Association affiliate, the Ohio State Medical Society.

\subsection{Listing of Relevant Interest Groups}

\subsubsection{List of Environmental Groups}

League of Ohio Sportsmen

4330 Cline Road, Columbus, Ohio 43228 (614-279-3444)

President: Thomas King

An umbrella organization of local sportsmen's clubs affiliated with the National Wildlife Federation. Activities include the preservation and restoration of natural habitat and wildife populations.

Ohio Audubon Council, Incorporated

4036 Cypress Road, N.W., Canton, Ohio 44705

President: Frank Stan, Jr.

Promotes wildlife conservation through a number of public education,

information transfer and research activities.

Ohio Environmental Council, Incorporated

850 Michigan Avenue, Columbus, Ohio 43215 (614-221-0898)

President: William L. Howard

Promotes conservation and protection of Ohio water resources.

Membership approximately 500.

National Water Well Association

500 West Wilson Bridge, Worthington, Ohio 43085 (614-846-9355)

Contact: David Nielsen

Professional organization of persons involved with groundwater

utilization. Concerns include protection of groundwater quality and

sound resource development. Membership approximately 8,500.

Ohio Alliance for Environmental Education

445 King Avenue, Columbus, Ohio 43201 (614-461-0136)

Ex. Director: Jane Haynes

A non-advocacy organization which provides information to Ohio citizens on all aspects of environmental issues.

* Contact names and telephone numbers are listed where avajlable. 


\subsubsection{Medical/Research Interest Groups}

Ohio Hospital Association

21 West Broad Street, Columbus, Ohio 43215 (614-221-7614)

Contact: Norman F. Clark

Organization which represents interests of 230 Ohio hospitals and health care institutions, performing legislative and information exchange activities.

Ohio State Medical Association

600 South High Street, Columbus; Ohio 43215 (614-228-6971)

Contact: Catherine Wisse

Professional organization of medical doctors involved with information transfer and legislative activities. Membership approximately 15,000.

The Ohio Academy of Science

$445 \mathrm{King}$ Avenue, Columbus, Ohio 43201 (614-424-6045)

President: Liberato Di Dio

Non-profit organization involved with research and scientific

information transfer in Ohio.

\subsubsection{Public Interest Groups}

League of Women Voters of Ohio

65 South Fourth Street, Columbus, Ohio 43215 (614-469-1505)

Contact: Edith Chase

Citizens organization representing 6,000 individual members. Primary

emphasis involves public education on current issues.

Ohio Public Interest Research Group

65 South Fourth Street, Columbus, Ohio 43215 (614-461-0136)

Contact: Matt Perrenod

Engages in wide range of public interest and consumer oriented policy research with an active interest in nuclear power issues.

Ohio Public Interest Campaign

1216 East McMillan Street, Cincinnati, Ohio 45206 (513-221-2100)

Associate Director: Harriet Applegate

Represents a coalition of 40 statewide and regional organizations concerned with environmental and social issues.

\section{2 .4 Labor Groups}

Ohio AFL-CIO

270 East State Street, Columbus, Ohio 43215 (614-224-8271)

Contact: John Thomas

Labor union representing approximately 1,200,000 individual members. Represents local unions at the State level; however, different unions may have different perspectives on waste issue, in particular, the International Brotherhood of Electrical Workers and the Oil, Chemical and Atomic Workers International Union. 


\section{2 .5 Other}

Ohio Chamber of Commerce

17 South High Street, Room 800, Columbus, Ohio 43215 (614-228-4201) Contact: Rosemary Martin

Represents 5,000 member businesses with a Department of Energy and Environment which tracks relevant legislation and regulations.

Ohio Municipal League

41 South High Street, Columbus, Ohio 43215 (614-221-4349)

Ex. Director: John Coleman

Represents 630 municipalities with a membership of over 7,000 municipal employees. Regularly active in environmental and land-use issues relevant to constituency. 
7. MASS MEDIA

\subsection{Introduction}

A review of the media issue coverage provides information on the quantity and coverage of the information citizens and decision-makers are receiving. An analysis of media coverage can thus be highly instructive in determining government concerns and public views toward an issue. In order to characterize the Ohio media coverage of the low-level radioactive waste issue, a review of articles and editorials published during 1979 and 1980 was conducted. This search was not intended to be exhaustive nor yield a representation of all radioactive issues of concern in Ohio.

Generally, newspapers maintain more detailed records of coverage than either of the electronic media. Therefore, the primary focus of the media review was upon newspapers. Ohio has 99 daily newspapers. To accomplish a valid characterization of the Ohio media, the State was reduced to three "media centers", corresponding to the major urban areas within the State: Cleveland, Columbus and Cincinnati. Within these areas the following newspapers were examined:

Cleveland Plain Dealer

Cleveland Press

Cincinnati Enquirer

Cincinnati Post

Columbus Dispatch

Columbus Citizen/Journal

\subsection{Media Coverage}

\subsubsection{Overview}

Cleveland is the dominant media center in the State. This is due to both the presence of the Cleveland Plain Dealer and the fact that 
Cleveland is the largest metropolitan area. The Plain Dealer is a regional newspaper and its influence extends well beyond the metropolitan area. The National Broadcasting Corporation also maintains a news bureau in Cleveland.

Columbus, being the State capital, is now the largest city in. Ohio. The Columbus Dispatch is the major source of news about State government for both decision-makers and other media. The CitizenJournal concerns itself with city affairs to a greater extent and has only half the readership of the Dispatch.

Cincinnati, due to its location in the southwestern corner of the State, tends to be removed from the mainstream of Ohio issues. Coverage of both the Enquirer and the Post is more narrowly focused than either the dominant Cleveland or Columbus dailies.

\subsubsection{Volume of Coverage}

Nuclear and radiation issues in general were of secondary importance in Ohio. The Three Mile Island (TMI) story was covered through wire stories and little apparent effort was made to localize the nuclear power issue by concentration upon operations of the nearby Davis-Besse Station.

The Cleveland dailies gave cursory coverage to the detection of radiation at a formerly utilized disposal site in nearby Newburgh. The exposure of Davis-Besse workers to slight levels of radiation also merited only brief coverage in the Cleveland papers.

The Columbus papers devoted some attention to the issue of radioactive waste transportation through Ohio, and State and local efforts to regulate this transportation. The Cincinnati media gave nuclear issues even less coverage and the issue of low-level radioaotive wastes was almost totally ignored until very recently. 


\subsubsection{Issues Raised}

The principal preoccupation of the Ohio media was with the transportation of nuclear wastes through Ohio enroute to final disposal sites. Numerous Ohio communities have recently adopted measures to strictly regulate or disallow the transportation of wastes within their boundaries. The Columbus Dispatch in particular covered the safety issues raised as well as the political ramifications involved with local abrogation of the interstate commerce clause.

No clear and consistent distinction was made between low-level and high-level radioactive waste concerns. In most instances, radioactive wastes are associated only with the operations of electrical generation facilities, and little mention was given to medical, industrial or military radioactive waste concerns.

During the newspaper interviews, the editors contacted were unable to explain the apparent preoccupation of ohio with radiation transportation issues. Editors consistently rated low-level radioactive wastes as a non-issue within the State, and generally supported nuclear power generation.

\subsection{Specific Media Coverage}

\subsubsection{Cleveland}

The Cleveland Press ran a few articles covering the discovery of trace radioactivity in Newburgh Heights, which resulted from the improper disposal of demolition wastes. The stories were short and were located in the City/State and surburban sections which tends to reveal their secondary importance in the eyes of the editorial staff. 
The Plain Dealer devoted greater coverage to nuclear issues in general and the transportation issue in particular. The Plain Dealer was especially concerned with Federal tendencies toward secrecy of waste movement. The Plain Dealer strongly supported the State's right to be involved with planning the transportation routes of radioactive wastes.

\section{$7 \cdot 3.2$ Columbus}

The Dispatch, the paper of record for State government activities, closely covered the transportation issue in Ohio. Editorially, the Dispatch supports uniform Federal regulations regarding low-level and hazardous waste transportation. These regulations should have state level input regarding allowable routes. The Dispatch takes an ambivalent stance on the proposed State ban on disposal. The Dispatch offers a luke-warm endorsement of the legislation as a method to place the State in a more advantageous position, but later argues that it is time to "bite the bullet" on the disposal issue and acknowledges Federal preeminence.

\subsubsection{Cincinnati}

Cincinnati papers showed the least interest in nuclear issues and covered low-level radioactive waste policy only in connection with local mishaps, such as traffic accidents involving waste shippers. Recently, however, the Enquirer had a cover story in its Sunday magazine on the benefits and concerns surrounding the use of radioactive materials. The Cincinnati media generally support the concept of nuclear power and considers waste and safety related issues as problems requiring a technical, rather than political solution. 


\subsection{Conclusions}

The Ohio media tend to be more conservative than other eastern media, both professionally and as a reflection of the Ohio political climate. Low-level radioactive waste is not an issue which commands much media attention and usually is considered only within the larger context of nuclear power. The media usually differentiate between low-level and high-level radioactive wastes when the context of the article requires this distinction; however, utilities are implicitly regarded as the sources of waste in most coverage. Possibly due to the position of Ohio as a trucking link between the industrial northeast and the western portions of the nation, waste transportation issues tend to receive more detailed coverage than disposal issues. 


\section{SURVEY METHODOLOGY}

A mail survey was conducted during December, 1980, of Nuclear Regulatory Commission (NRC) licensees in the State of Ohio. The names of the license holders were-obtained from a computerized listing provided by the NRC. Since the NRC listing did not contain the names of the Radiation Safety officers (RSO), or an appropriate contact person, the State Radiation Safety office was contacted in order to see if any registration was required of those licensed to handle radioactive materials. A separate list of names was provided by the Ohio Department of Health based on their records.

This survey was intended to classify license holders by type of licensed facility and to determine if they disposed of low-level radioactive waste by shipment to commercial disposal facilities and, if not, what other disposal methods were employed. The survey used and instruction sheet are presented in Figure 8-1. A letter of transmittal and a return envelope were also provided (see Figure 8-2). The letter indicated that the State Radiation Safety office endorsed the survey and that licensee responses were encouraged.

The survey instrument used may be characterized as primarily being "closed ended" which would force respondents to answer specific alternative responses. However, for those questions where there are a variety of possible responses, some of which may not be reflected in the survey question, "open ended" responses were allowed. The questions used in the survey were limited to those which have a direct bearing on the characterization of low-level radioactive waste management practices in the State. Respondents were assured that the data obtained would only be reported in aggregate form.

Two weeks after the surveys were mailed, an assessment was made as to the response rate and the type of licensees returning surveys. Based on contacts with the NRC regional offices in Chicago, Illinois, and King of Prussia, Pennsylvania, a listing of NRC licensees was obtained by category 


\section{SYNERGIC RESOURCES CORPORATION \\ LOW-LEVEL WASTE GENERATOR SURVEY}

GENERAI INSTRUCTIONS

1. The enclosed Radioactive waste Survey is self-explanatory. The following instructions provide general guidelines. If you have any specific concerns, please call Todd D. Davis or Steve Isser at:

$$
215-667-2160
$$

2. If possible, all quantitative data should be taken directly from shipment records. If this is not practical, please estimate answers as accurately as possible. We prefer to have actual data rather than estimates.

3. Please explain or specify answers (where requested) as completely as possible. If additional space is needed, please use the "Additional Comments" section on the last page of this questionnaire.

4. When you have completed this questionnaire, please return it in the enclosed stamped, self-addressed envelope.

5. If your facility does not dispose of radioactive materials by use of the commercial radioactive material disposal sites, please fill out the survey form with the amount of material received in each year and where those radioactive materials received were disposed (e.g. Isotopes used in patient treatment residues decayed to background, disposed in trash, or shipped out in finished products).

THANK YOU VERY MUCH FOR YOUR CO-OPERATION

Figure 8-1 


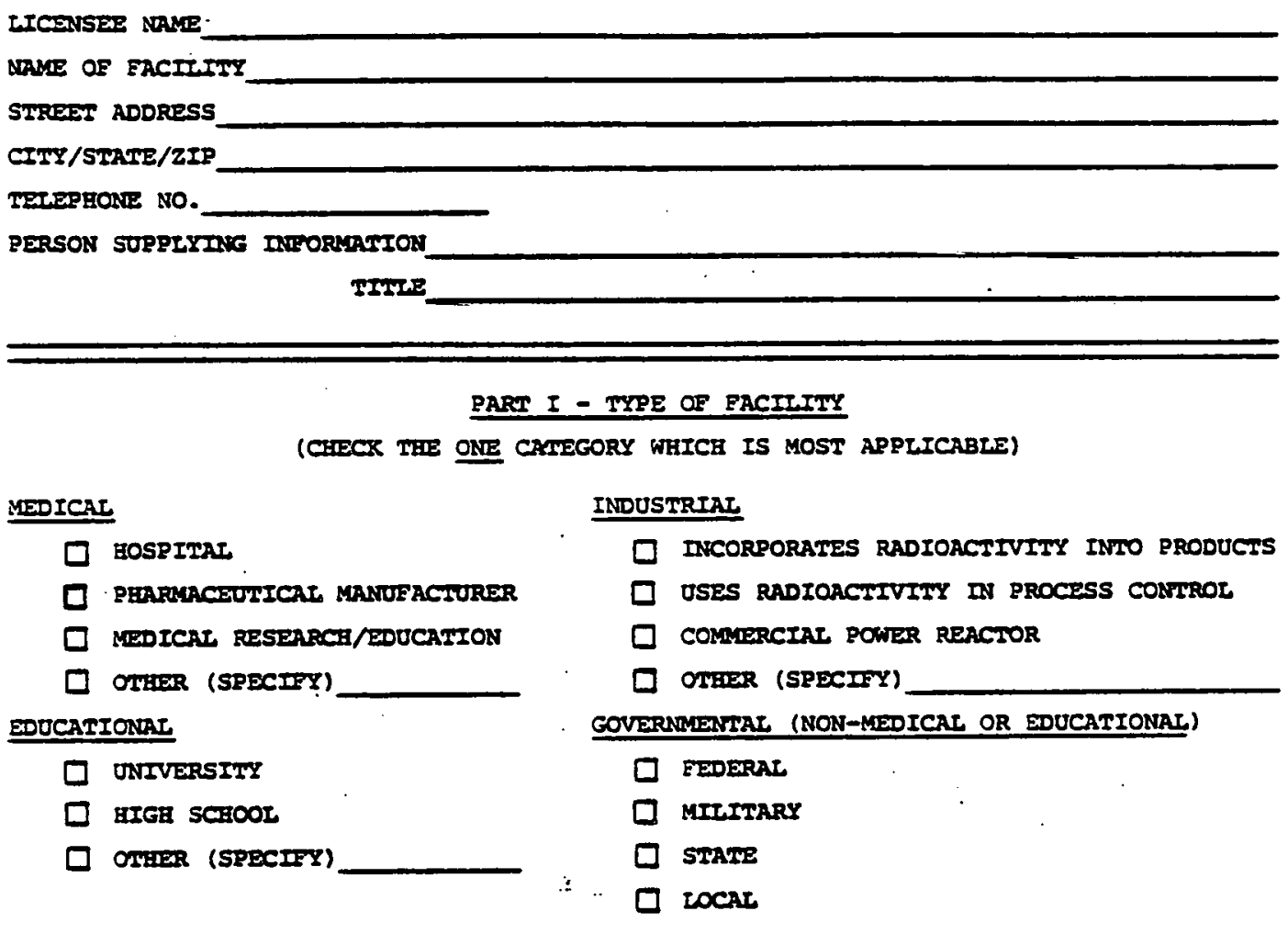

PART II - DISPOSAC MEIHOD

CHECX EACH DISPOSAL METHOD WAICE YOO DO EMPLOY
口 SHTP TO COMLIARCIAI REPOSITORY
口 RETEASE TO SEWER
口 COMBINE WITH COMMON REFUSE
D VENT tO ATMOSPHERE
$\square$ BURN ON-SITE
口 RETURN TO VENDOR
$\square$ DISTRIBUTE IN PRODUCT FORM
D NO WASTE GENERATED
$\square$ OTFIER (SPECIFY)

Figure 8-1. (Continued) 
(CEIECX EACH SOURCE OF YOUR POTENTLAL RADIOACTIVE WASTE AND, IF YOO SAIP, INDICATE THE PERCENTAGE OF YOUR TOTAL SEIPPED WASTE VOLTER ORIGIMTEAT EROM EACT SOURCE CATEGORY).

SOURCE OF RADIOACIIVITY

D MUCLEAR REACTOR

D NETHRON GDIERATOR

a CTCLOTRON OR STMCHROTRON

Q SEATED SOURCE

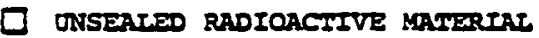

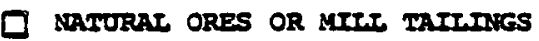

COTHER (SPBCTFY)
PERCEANT OF WASTE VOLOTE SHIPPED

IF YOO DO NOT SHIP RADIOACTIVE WASTES, YOU GAVE COMPLETED THE QUESTIOMNAIRE. THANK YOU. IF YOO DO SRIP, PLEASE CONTINUE WITH THE FOLTOWING QUESTIONS.

PARI IV - PEYSICAL FORM OF SHIPPED WASTES

(CEIECK EACR FORM OF WASTE WHICH YOO SHIP AND INDICATE THE PERCINTAGE OF YOUR TOTAL SEIPPED WASTE VOLOME REPRESENTIING EACH EORM).

D DRY SOLIDS, TRASH, IRRADIATED COMPONENTS SOLIDIFIED OR ABSORBED LIQUIDS, SOLTD SLUDGES,

GPENT RESINS, FIITER SIUDGES OR EVAPORATOR BOTHOMS

D antMal capcasses OR OTHER bIOLOGICAr WASTE

SEATED SOURCES

$\square$ OTERR (SPECIFY)

DOES WASTE CONTAAN ANY MATERIAT WHICA IS POTENTIALCY:
YES NO
$\square \square$ COMBUSTIELE
$\square$ exprostre
[ $\square$ cymicatiy TOXIC

WEAT SHIPPING CONTAINERS DO YOU USE?

$\square \quad 55$ GAITON STEET DRUMS
$\square \quad 30$ GATION STEET DROMS
$\square \quad$ OTHER (SPECIFY)

WTAT ON-SITE PROCESSING OF WASTE DO YOU EMTLOY?

$\square$ NONE

$\square$ MECHANICAI COMPACTION

7 InCINERATION

$\square$ SOLIDIFICATION OR EVAPORATION OF LIQUIDS

$\square$ ABSORPTION OF LIQUIDS

$\square$ OTHER (SPECIFY)

Figure 8-1. (Continuec) 
PART V - WASTE QUANTIIY

INDICATE TOTAL YEARLY VOLOME (IN CUBIC EEEM) OP WASTE SEIPPED TO A COMIIERCIAL DISPOSAI RACIIITY.

\section{COBIC FEET SHIPPED}

ACHUAC SHIPPED IN 1978
ACLUAC SHIPPED IN 1979
ACIUAC SHIPPED IN 1980

INDICATE TOTAI YEARLY VOLONE (IN CUBIC FEET) OF WASTE PROTECTED TO BE GENEARATED WHICA WIII BE SHIPPED.

\section{CUBIC FEET GEANERATED}

ESTIMATED GENRRATION IN 1981

ESTIMATED GENERATION IN 1985

ESTIMATEO GENERATIOA IN 1990

INDICATE SER QUANTITY OF RADIOACIIVITY (IN CURIES) SHIPPED TO A COMAERCIAL FACILITY IN THE YEARS 1978, 1979 AND 1980.

\begin{tabular}{|l|l|l|l|}
\hline \multirow{2}{*}{ ISOTOPE } & \multicolumn{3}{|l|}{ QUANIITY SRIPPED (CURIES) IN: } \\
\cline { 2 - 4 } & 1978 & 1979 & 1980 \\
\hline & $\cdot$ & & \\
\hline & & & \\
\hline & & & \\
\hline & & & \\
\hline & & & \\
\hline & & & \\
\hline & & & \\
\hline & & & \\
\hline & & & \\
\hline
\end{tabular}

Figure 8-1. (Continued) 


\section{$\mathbf{s \mathbb { R }}\rangle$}

Synergic Resources Corporation (SRC) is a subcontractor to EGsG Idaho, Inc., on a project for the U.S. Department of Energy to develop state briefing books on low level zadioactive waste concerns. This project is being conducted with the cooperation and endorsement of the Ohio Department of Eealth and Ohio Environmental Protection Aigency.

A major feature of these briefing books will be information on the volume, sources, physical forms, and profections of low level waste. Surveys are being conducted for all Nuclear Regulatory Commission (NRC) licensees. Since you are an NRC Iicensee, we would appreclate lt if you would complete the attached questionnaire today.

Data obtained erom these surveys will be kept confidential and will only be reported in aggregated form by type of low level waste generators (e.g., commercial power reactors, medical institutions, etc.). The information you provide will be used to obtain a profile of low-level waste generated in your state and assist in the consideration of alternative approaches in developing a low-level waste management program. We are sure that you are aware of public concerns, government interest, and the desire on the part of the private sector to properly manage low level waste in the United States.

Again, we would appreciate your completing the survey today and returning it in the enclosed self-addressed, stamped envelope. The information you provide will remain confidential. If you need additional time to provide more detailed anc accurate information, please take no more than Eive days to comolete this survey. The aore detailed the information you provide, the moce meaningful the sesults of sie surveys.

Should you ha\%e any questions gegzzding the completion of this sity:\%, plessa cali SRC at 215-557-2160, and ask for stare Isser, or myjele.

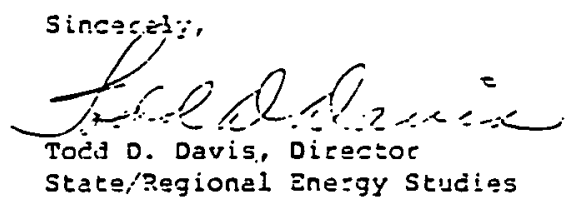

TDO: 16

ONE BALA.CYNWYD PLAZA. SUITE $630 \bullet$ BALA.CYNWYD.PA. $19004 \bullet \bullet 15.667 .2160$


and priority of licensed activity. Those licensees identified in categories that are known to generate a significant volume of low-level radioactive waste were then contacted by phone in order to encourage their response. of those licensees contacted, all agreed to return the survey. Not all returned the surveys, however.

It is believed that the first two categories account for over 75 percent of the low-level radioactive waste generated. For the remaining non-respondents, a follow-up letter and postcard were sent in order to notify licensees that a survey had been sent and that their response was requested (see Figure 8-3). A postcard was provided in order to determine if the licensee received the survey and did or did not intend to respond; did not receive the survey and would respond if another was sent; or, received the survey, but only generated sealed sources of radiation. If the licensees indicated that they only generated sealed sources, no further contact was made. Postcard responses were counted as a specific type of response.

Response rates in the medical category IV-G, containing 195 hospitals and other medical licenses, were felt to be significantly low, as many in this group were believed to be potential shippers. Thus a selective telephone survey was made by first analyzing the American Hospital Association's 1979 Annual Guide to the Health Care Field to determine which hospitals had significant nuclear medicine or radiation therapy programs. These facilities were then contacted. A total of 29 hospitals was contacted of which only three turned out to be shippers of low-level radioactive waste. Data were gathered on disposal method, the source of radioactive waste, shipping container and actual shipped volume for 1978, 1979 and 1980. Five educational institutions (priority III-F1A) were also contacted, of which four were shippers.

It was discovered in the survey analysis that nuclear power plants were not included in the original NRC licensee listings, since they are licensed under a different category of licensees. Title $X$ of the Code of Federal 
Regulations was referred to for a more detalled breakdown of licensing categories. Nuclear power plants are licensed under Part 50 of the Code and have broader authorizations. Contact names were then obtained from the utilities which have active nuclear power plants in the State.

The information received from the licensees was then tabulated. The results appear in in Sections 2.0 and 9.0 of this report. 


\section{A PROFILE OF LOW-LEVEL RADIOACTIVE WASTE GENERATION}

AND DISPOSAL

In the State of Ohio, a total of 588 potential shippers of low-level radioactive waste were identifled. These potential shippers were initially contacted by mail and some received a follow-up telephone call. The respondents were identified as either a medical, educational, industrial, power reactor, or governmental type facility. Section 2.0 presents data on the number of respondents using various disposal methods and the source of radioactivity used at facilities. Table 9-1 indicates that 15.7 percent (45 facilities) of the respondents use commercial low-level waste facilities. What follows is a summary of the characteristics and quantity of low-level radioactive waste disposed by these facilities.

\subsection{Survey Response}

Table 9-2 presents, by facility type, the number of potential shippers of low-level radioactive waste surveyed, the total number and percentage of responses obtained, and a breakdown of responses by type of response. If a facility provided at least the facility type and method of disposal, the answer to the survey was considered a response. If no information was obtained, the type of facility was determined by the NRC license category to which the licensee was assigned. The responses were classified into four groups by the type of response. Group One responses were responses in which all appropriate information was provided except estimated generation (see Figure 8-1). Group Two responses include partial responses that were missing one or two questions, but all included the type of facility and disposal method. Group Three responses were obtained by the follow-up telephone survey. Group Four responses were obtained by postcard.

of the 588 potential shippers identified, 49 percent provided some degree of response. The range of responses by type of facility was 35 
TABLE 9-1. USE OF COMMERCIAL LOW-LEVEL WASTE FACILITIES

\begin{tabular}{|c|c|c|c|c|c|c|}
\hline \multirow{2}{*}{$\begin{array}{l}\text { PRIORITY } \\
\text { CATEGORY }\end{array}$} & \multirow{2}{*}{ 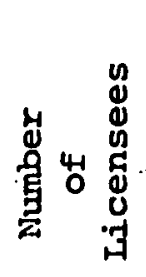 } & \multirow{2}{*}{ 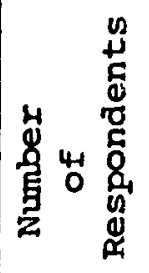 } & \multirow{2}{*}{ 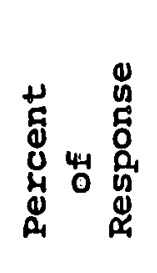 } & \multicolumn{3}{|c|}{ Respondents Using a Commercial Facility } \\
\hline & & & & Number & $\begin{array}{l}\text { Percent } \\
\text { of all } \\
\text { Respondents }\end{array}$ & $\begin{array}{l}\text { Percent of } \\
\text { Respondents in } \\
\text { Priority/Facility }\end{array}$ \\
\hline 1. Top Priorities & 23 & 22 & 95.65 & 18 & 6.27 & 81.82 \\
\hline 2. Middle priorities & 244 & 165 & 67.62 & 23 & 8.01 & 13.94 \\
\hline 3. All others & 321 & 100 & 31.15 & 4 & 1.39 & 4.00 \\
\hline $\begin{array}{l}\text { TYPE OF FACILITY } \\
\text { (All Priorities) }\end{array}$ & & & & & & . \\
\hline Medical & 195 & 126 & 64.62 & 10 & 3.48 & 7.94 \\
\hline Educational & 34 & 29 & 85.29 & 13 & 4.53 & 44.83 \\
\hline Industrial & 322 & 112 & 34.78 & 16 & 5.57 & 14.29 \\
\hline Governmental & 35 & 18 & 51.43 & 4 & 1.39 & 22.22 \\
\hline Power Reactor & 2 & 2 & 100.00 & 2 & 0.69 & 100.00 \\
\hline TOTAL & 588 & 287 & 48.81 & 45 & 15.68 & 15.68 \\
\hline
\end{tabular}


TABבE 9-2. ANALYSIS OF OVERALL SURVEY RESPONSE

\begin{tabular}{|c|c|c|c|c|c|c|c|c|c|c|c|c|c|c|c|c|}
\hline \multirow{4}{*}{$\begin{array}{l}\text { PRIORITY } \\
\text { CATEGOBY }\end{array}$} & \multicolumn{16}{|c|}{ Degree of Response } \\
\hline & \multicolumn{8}{|c|}{ tlon-Shippers } & \multicolumn{8}{|c|}{ shipperi } \\
\hline & \multicolumn{2}{|c|}{ Group I } & \multicolumn{2}{|c|}{ Group II } & \multicolumn{2}{|c|}{ Group III } & \multicolumn{2}{|c|}{ Group IV } & \multicolumn{2}{|c|}{ Group I } & \multicolumn{2}{|c|}{ Group II } & \multicolumn{2}{|c|}{ Group III } & \multicolumn{2}{|c|}{ Group IV } \\
\hline & $\begin{array}{c}\text { No. } \\
\text { of } \\
\text { Resp. }\end{array}$ & $\begin{array}{c} \\
\text { of } \\
\text { Resp. }\end{array}$ & $\begin{array}{l}\text { No. } \\
\text { of } \\
\text { Fesp. }\end{array}$ & \begin{tabular}{|c|} 
\\
of \\
Resp.
\end{tabular} & $\begin{array}{l}\text { No. } \\
\text { of } \\
\text { Resp. }\end{array}$ & $\begin{array}{c} \\
\text { of } \\
\text { Resp. }\end{array}$ & $\begin{array}{l}\text { No. } \\
\text { of } \\
\text { Resp. }\end{array}$ & $\begin{array}{c} \\
\text { of } \\
\text { Resp. }\end{array}$ & $\begin{array}{c}\text { No. } \\
\text { of } \\
\text { Resp. }\end{array}$ & \begin{tabular}{|c|} 
\\
of \\
Resp.
\end{tabular} & $\begin{array}{l}\text { No. } \\
\text { of } \\
\text { Resp. }\end{array}$ & $\begin{array}{c} \\
\text { of } \\
\text { Resp. }\end{array}$ & \begin{tabular}{|c|} 
No. \\
of \\
Resp.
\end{tabular} & \begin{tabular}{|c|} 
\\
of \\
Resp.
\end{tabular} & $\begin{array}{l}\text { No: } \\
\text { of } \\
\text { Resp. }\end{array}$ & $\begin{array}{c}\text { of } \\
\text { of } \\
\text { Resp. }\end{array}$ \\
\hline 1. Top Priorities & 4 & 18.18 & 0 & 0.00 & $\mathbf{0}$ & 0.00 & 0 : & 0.00 & 11 & 50.00 & 3 & 13.64 & 4 & 18.18 & 0 & 0.00 \\
\hline 2. Middla Priorities & 68 & 41.21 & 23 & 13.94 & 27 & 16.36 & 24. & 14.55 & 18 & 10.91 & 3 & 1.82 & 2 & 1.21 & 0 & 0.00 \\
\hline 3. All others & 81 & 81.00 & 15 & 15.00 & 0 & 0.00 & $\mathbf{0}$ & 0.00 & 1 & 1.00 & 0 & 0.00 & 3 & 3.00 & $\mathbf{0}$ & 0.00 \\
\hline $\begin{array}{l}\text { TYPE OF EACILITY } \\
\text { (ALl Priorities) }\end{array}$ & & & & & & & & & & & & & & & & \\
\hline Hedical & 54 & 42.86 & 24 & 19.05 & 26 & 20.63 & 12 & 9.52 & 4 & 3.17 & 3 & 2.38 & 3 & 2.38 & 0 & 0.00 \\
\hline Educational & 9 & 31.03 & 1 & 3.45 & 1 & 3.45 & 5 & 17.24 & 9 & 31.03 & 0 & 0.00 & 4 & 13.79 & 0 & 0.00 \\
\hline Industrial & 78 & 69.64 & 11 & 9.82 & $\mathbf{0}$ & 0.00 & 7 & 6.25 & 13 & 11.60 & 1 & 0.89 & 2 & 1.79 & 0 & 0.00 \\
\hline Governmental & 12 & 66.67 & 2 & 11.11 & 0 & 0.00 & 0 & 0.00 & 3 & 16.67 & 1 & 5.56 & 0 & 0.00 & 0 & 0.00 \\
\hline Power Reactors & 0 & 0.00 & $\mathbf{0}$ & 0.00 & 0 & 0.00 & 0 & 0.00 & 1 & 50.00 & 1 & 50.00 & 0 & 0.00 & 0 & 0.00 \\
\hline TOTAI. & 153 & 53.51 & 38 & 33.24 & 27 & 9.41 & 24 & 8.36 & 30 & 10.45 & 6 & 2.09 & 9 & 3.14 & 0 & 0.00 \\
\hline
\end{tabular}


percent for industrial and 85 percent for educational. of all respondents, 64 percent provided all requested information, while 51 percent of potential respondents provided no information or response.

\subsection{Sources of Shipped Wastes}

\subsubsection{Distribution by Type of Facilities Shipping Wastes}

Table 9-3 provides data on the number and type of facilities shipping wastes. The type of facility is also broken into subgroupings.

All facilities checking both "medical research/education" and also "university" were reported in the medical category and not in the educational. It should also be noted that pharmaceutical manufacturers were classified as "industrial", even though the survey labeled them as "Medical". The "other" category in the medical group includes doctors' offices, clinics, out-patient care facilities, blood centers, and medical laboratories.

In the educational category, the "other" response was checked by one institute and specified as "analytic training".

There were a wide range of uses included in the "other" response for the industrial category: laboratory work, soil density gauges, oil and gas exploration, centrifuge research, highway construction, glass colorant, back lighting LCD's (tritium cells), food processing, analytical testing, etc. Some of these responses might properly have belonged in the "Process Control" response and vice-versa.

The data in Table 9-3 show that hospitals represent the greatest proportion of low-level radioactive waste material shipped by medical facilities ( 80 percent). of educational institutions, universities represented all the waste volumes reported to be shipped to commercial facilities. Over half of the low-level waste shipped by industrial 
TABLE 9-3. TYPE OF FACILITIES SHIPPING LOW-LEVEL WASTE

\begin{tabular}{|c|c|c|c|}
\hline Type of Facility & $\begin{array}{r}\text { Number of } \\
\text { Facilities } \\
\text { Shipping } \\
\end{array}$ & $\begin{array}{l}\text { Percent } \\
\text { Of All } \\
\text { Shippers } \\
\end{array}$ & $\begin{array}{c}\text { Percent of } \\
\text { Facilities } \\
\text { Type } \\
\end{array}$ \\
\hline Medical & & & \\
\hline $\begin{array}{l}\text { Hospital } \\
\text { Research/Education } \\
\text { Other }\end{array}$ & $\begin{array}{l}8 \\
1 \\
1\end{array}$ & $\begin{array}{r}19.51 \\
2.44 \\
2.44\end{array}$ & $\begin{array}{l}80.00 \\
10.00 \\
10.00\end{array}$ \\
\hline Total & 10 & 24.39 & 100.00 \\
\hline Educational & & & \\
\hline $\begin{array}{l}\text { University } \\
\text { High School } \\
\text { Other }\end{array}$ & $\begin{array}{r}12 \\
0 \\
0\end{array}$ & $\begin{array}{r}29.27 \\
0.00 \\
0.00\end{array}$ & $\begin{array}{r}100.00 \\
0.00 \\
0.00\end{array}$ \\
\hline Total & 12 & 29.27 & 100.00 \\
\hline Industrial & & & \\
\hline $\begin{array}{l}\text { Pharm. Mfg.* } \\
\text { Product Use } \\
\text { Process Control } \\
\text { Other }\end{array}$ & $\begin{array}{l}1 \\
3 \\
2 \\
8\end{array}$ & $\begin{array}{r}2.44 \\
7.32 \\
4.88 \\
19.51\end{array}$ & $\begin{array}{r}7.14 \\
21.43 \\
14.29 \\
57.14\end{array}$ \\
\hline Total & 14 & 34.15 & 100.00 \\
\hline Power Reactor Total & $2^{\therefore}$ & 4.88 & 100.00 \\
\hline Government & & & \\
\hline $\begin{array}{l}\text { Federal } \\
\text { Military } \\
\text { State } \\
\text { Local }\end{array}$ & $\begin{array}{l}3 \\
n \\
0 \\
0\end{array}$ & $\begin{array}{l}7.32 \\
0.00 \\
0.00 \\
0.00\end{array}$ & $\begin{array}{r}100.00 \\
0.00 \\
0.00 \\
0.00\end{array}$ \\
\hline Total & 3 & 0.00 & 0.00 \\
\hline TOTAL & 41 & 100.00 & 100.00 \\
\hline
\end{tabular}

*Pharmaceutical Manufacturing 
facilities was from the "other" subgrouping. Of the government facilities reporting, only Federal facilities reported shipping low-level radioactive wastes $(\mathrm{N}=3)$.

\subsubsection{Origin of Radioactivity Resulting in Shipped Wastes}

Three major categories were used to define the origin of radioactivity resulting in shipped wastes: nuclear reactor operation, purchases of sealed sources, and purchases of unsealed radioactivity. Table 9-4 presents the distribution of the number of facilities to the type of facility and origin of radioactivity. It should be noted that more than one origin may be appropriate for a given facility. Seventy-eight percent of the licensees reporting the shipping of low-level waste obtain the radioactivity as unsealed radioactive material. Nuclear reactors provided 17 percent of the radioactivity shipped, and sealed sources provided 32 percent of the radioactivity resulting in shipped wastes.

\subsection{Volume of Shipped Waste}

Table $9-5$ provides data on the volumes of shipped wastes for the years 1978, 1979 and 1980 for each type of facility and for subgroups of each facility type. Volumes of low-level wastes shipped to commercial disposal facilities were reported by 39 of the 45 facilities reporting that they ship wastes.

The table shows that 61,841 cubic feet of low-level radioactive waste were shipped in 1980, versus 26,740 cubic feet in 1978. In 1978, power reactors provided the greatest volume of shipped waste $(12,000$ cubic feet), whereas industrial wastes were the largest portion in $1980(36,845$ cubic feet). In terms of volume, hospitals, educational institutions and government facilities generated less than 15 percent of the total volumes reported in 1980 . 
TABLE 9-4. ORIGIN OF RADIOACTIVITY RESULTING IN SHIPPED WASTE

\begin{tabular}{|c|c|c|c|c|c|c|c|}
\hline \multirow{2}{*}{$\begin{array}{r}\text { Type of } \\
\text { Facility } \\
\end{array}$} & \multirow{2}{*}{$\begin{array}{c}\text { Number of } \\
\text { Respondents } \\
\end{array}$} & \multicolumn{2}{|c|}{ Nuclear Reactor } & \multicolumn{2}{|c|}{ Sealed Sources } & \multicolumn{2}{|c|}{$\begin{array}{l}\text { Unsealed Radioactive } \\
\text { Material }\end{array}$} \\
\hline & & Number & Percent & Number & Percent & Number & Percent \\
\hline Medical & 10 & 0 & 0.00 & 4 & 40.00 & 8 & 80.00 \\
\hline Edicational & 12 & 1 & 8.33 & 4 & 33.33 & 10 & 83.33 \\
\hline Industrial & 14 & 3 & 21.43 & 5 & 35.71 & 11 & 78.57 \\
\hline Power Reactor & 2 & 2 & 100.00 & 0 & 0.00 & 0 & 0.00 \\
\hline Government & 3 & 1 & 33.33 & 0 & 0.00 & 3 & 100.00 \\
\hline TOTAL & 41 & 7 & 17.07 & 13 & 31.71 & 32 & 78.05 \\
\hline
\end{tabular}


TABLE 9-5. VOLUME OF WASTE SHIPPED

\begin{tabular}{|c|c|c|c|c|c|c|c|}
\hline \multirow[b]{2}{*}{ Type of Facility } & \multirow[b]{2}{*}{$\begin{array}{c}\text { Number of } \\
\text { Respondents } \\
\end{array}$} & \multicolumn{2}{|c|}{1978} & \multicolumn{2}{|c|}{1979} & \multicolumn{2}{|c|}{1980} \\
\hline & & Cu. Ft. & Percent & Cu. Ft. & Percent & Cu. Ft. & Percent \\
\hline \multicolumn{8}{|l|}{ Medical } \\
\hline $\begin{array}{l}\text { Hospital } \\
\text { Research/Education } \\
\text { Other }\end{array}$ & $\begin{array}{l}7 \\
1 \\
1\end{array}$ & $\begin{array}{r}1851.10 \\
0.00 \\
14.70\end{array}$ & $\begin{array}{l}6.92 \\
0.00 \\
0.05\end{array}$ & $\begin{array}{r}2092.40 \\
525.00 \\
14.70\end{array}$ & $\begin{array}{l}3.28 \\
0.82 \\
0.02\end{array}$ & $\begin{array}{r}1973.00 \\
270.00 \\
14.70\end{array}$ & $\begin{array}{l}3.19 \\
0.44 \\
0.02\end{array}$ \\
\hline Total & 9 & 1865.80 & 6.98 & 2632.10 & 4.13 & 2257.70 & 3.65 \\
\hline \multicolumn{8}{|l|}{ Educational } \\
\hline $\begin{array}{l}\text { University } \\
\text { High School } \\
\text { Other }\end{array}$ & $\begin{array}{r}12 \\
0 \\
0\end{array}$ & $\begin{array}{r}3789.36 \\
0.00 \\
0.00\end{array}$ & $\begin{array}{r}14.17 \\
0.00 \\
0.00\end{array}$ & $\begin{array}{r}3710.10 \\
0.00 \\
0.00\end{array}$ & $\begin{array}{l}5.82 \\
0.00 \\
0.00\end{array}$ & $\begin{array}{r}4797.60 \\
0.00 \\
0.00\end{array}$ & $\begin{array}{l}7.76 \\
0.00 \\
0.00\end{array}$ \\
\hline Total & 12 & 3789.36 & 14.17 & 3710.10 & 5.82 & 4797.60 & 7.76 \\
\hline Industrial & & $\therefore$ & & $\cdot$ & & . & \\
\hline $\begin{array}{l}\text { Pharm. Mfg.* } \\
\text { Product Use } \\
\text { Process Control } \\
\text { Other }\end{array}$ & $\begin{array}{l}1 \\
3 \\
2 \\
7\end{array}$ & $\begin{array}{r}90.00 \\
639.10 \\
0.00 \\
8044.00\end{array}$ & $\begin{array}{r}0.34 \\
2.39 \\
0.00 \\
30.08\end{array}$ & $\begin{array}{r}232.00 \\
181.80 \\
18.00 \\
47407.00\end{array}$ & $\begin{array}{r}0.36 \\
0.29 \\
0.03 \\
74.39\end{array}$ & $\begin{array}{r}214.00 \\
7.50 \\
15.00 \\
36608.50\end{array}$ & $\begin{array}{r}0.35 \\
0.01 \\
0.02 \\
59.20\end{array}$ \\
\hline Total & 13 & 8773.10 & 32.81 & 47838.80 & 75.07 & 36845.00 & 59.58 \\
\hline $\begin{array}{l}\text { Power Reactor Total } \\
\text { Government }\end{array}$ & 2 & $i 2000.00$ & 44.88 & 9184.00 & 14.41 & 17513.00 & 28.32 \\
\hline $\begin{array}{l}\text { Federal } \\
\text { Military } \\
\text { State } \\
\text { Local }\end{array}$ & $\begin{array}{l}3 \\
0 \\
0 \\
0\end{array}$ & $\begin{array}{r}311.50 \\
0.00 \\
0.00 \\
0.00\end{array}$ & $\begin{array}{l}1.16 \\
0.00 \\
0.00 \\
0.00\end{array}$ & $\begin{array}{r}360.00 \\
0.00 \\
0.00 \\
0.00\end{array}$ & $\begin{array}{l}0.56 \\
0.00 \\
0.00 \\
0.00\end{array}$ & $\begin{array}{r}427.50 \\
0.00 \\
0.00 \\
0.00\end{array}$ & $\begin{array}{l}0.69 \\
0.00 \\
0.00 \\
0.00\end{array}$ \\
\hline Total & 3 & 311.50 & 1.16 & 360.00 & 0.56 & 427.50 & 0.69 \\
\hline TOTAL & 39 & 26739.75 & 100.00 & 63724.99 & 100.00 & 61840.78 & 100.00 \\
\hline
\end{tabular}

*Pharmaceutical Manufacturing 
Table 9-6 shows the volumes in cubic feet of estimated future waste generation, as provided by the 28 respondents who gave these projections. It should be noted that based on telephone interviews, on-site visits, and comments written by the respondents on the survey instrument, the projected volumes should be viewed at best as only crude estimates. Therefore, any interpretation of the projected waste volumes should be done cautiously. Another factor to consider is the definition of low-level radioactive waste and NRC rulemaking regarding disposal practices. An increasing number of institutions have reported holding such waste on-site until it decays to background levels, when it is disposed with common refuse. The projected volume of low-level radioactive waste in Ohio is 30,694 cubic feet in 1981 , 45,337 cubic feet in 1985, and 47,012 cubic feet in 1990. The estimated volumes by type of facility show that power reactors will be the largest sources of low-level radioactive waste for 1985 and 1990. However, in 1981, power reactors and industry will each provide roughly 12,000-13,000 cubic feet of low-level radioactive waste. Universities and "other" industrial facilities are also significant generators of low-level radioactive waste.

\subsection{Activity of Shipped Waste}

Table 9-7 shows the amount of activity in shipped waste for the years 1978, 1979 and 1980. The total number of respondents to this question $(\mathrm{N}=27)$ is lower than the total number of shippers $(\mathrm{N}=45)$ because 18 respondents provided no information on activity. Of those who did respond, most appeared to carefully and methodically present the data. Still, many of these figures may be approximations. It should also be noted that, while zeros appear for many isotopes, actual data were provided but the coding scheme used oes not report data for the lower activity levels.

In 1978 and 1979, industrial facilities of various types provided the largest proportion of activity shipped to commercial disposal facilities ( 99 percent). In 1980, the proportion of activity of shipped waste by industry decreased to 53 percent. Of the industrial facilities, "product use" and "other" uses provided the greatest levels. of activity found in shipped waste. 
TABLE 9-6. ESTIMATED GENERATION (CU. FT.)

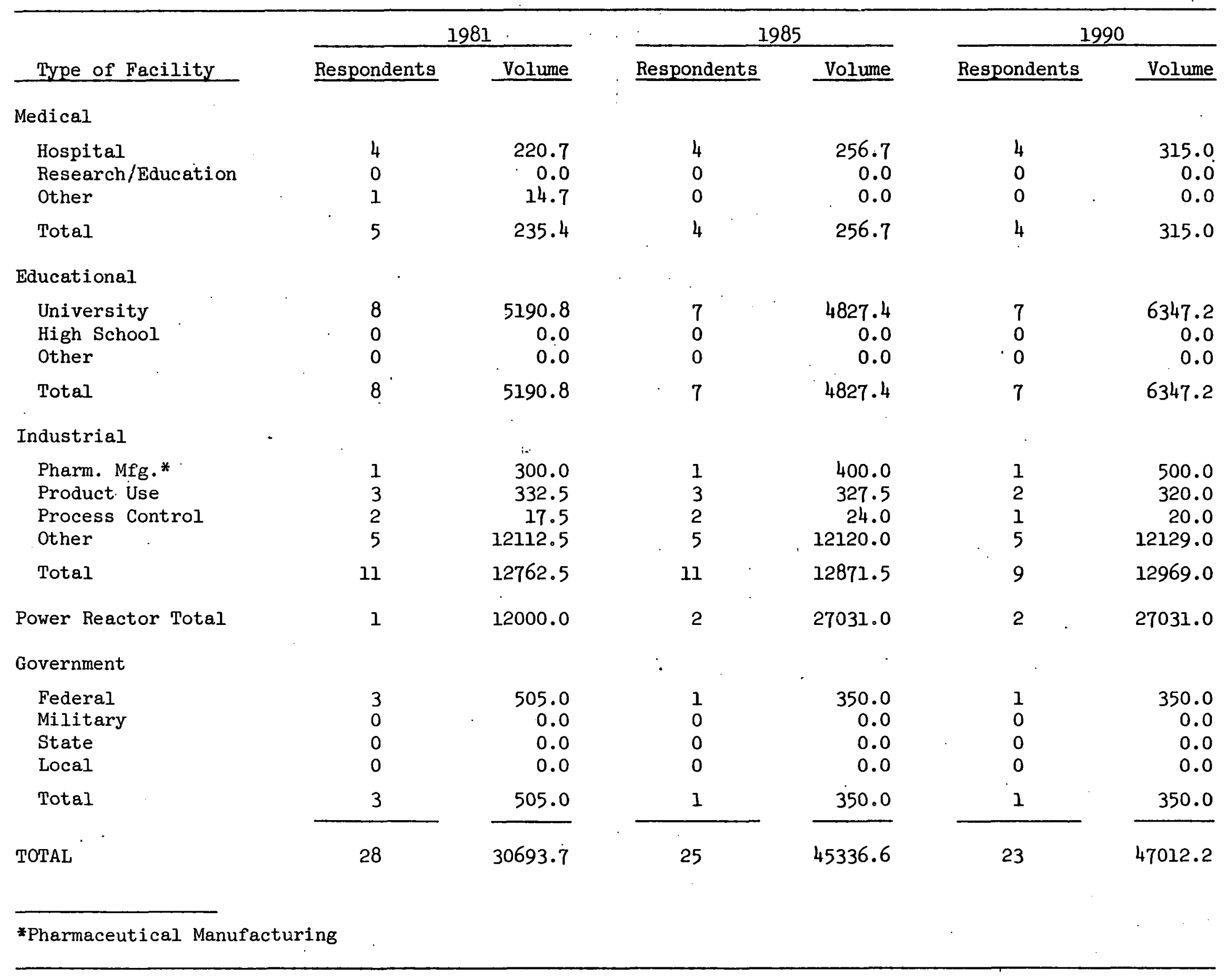


TABLE 9-7. ACTIVITY OF SHIPPED WASTE

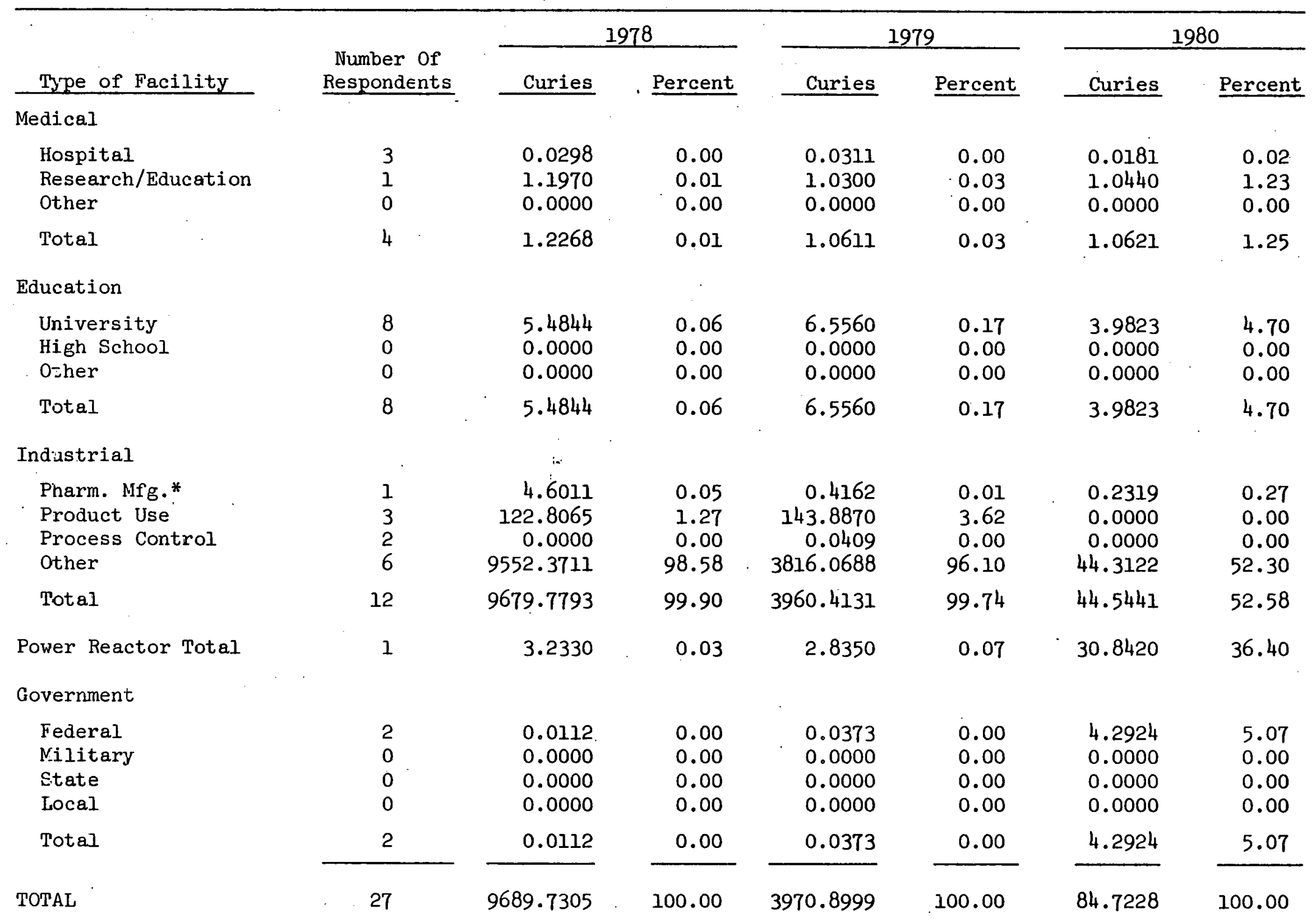

*Pharmaceutical Manufacturing 
Tables 9-8 through 9-13 present the distribution of activity by shipped radionuclide. This listing represents the isotopes as provided by respondents; presumably, other isotopes may be in use by non-respondents. In 1978, 1979 and 1980, industrial facilities accounted for the largest number of radionuclides in shipped wastes. It should also be noted that the year-to-year levels of the largest shippers vary significantly.

\subsection{Physical Characteristics of Shipped Wastes}

Low-level waste may be processed on-site by either reducing the volume of the waste (e.g., compaction, incineration) or by removing free liquid (e.g., solidification, absorption). Table 9-14 shows the number of facilities using these methods. The most common type of on-site processing of low-level radioactive waste is absorption ( 34 percent), followed by mechanical compaction (25 percent). Thirty-four percent of the respondents reported using no on-site processing of low-level radioactive waste. It should also be noted that, while zeros appear for many isotopes, actual data were provided but the coding scheme used does not report data for the lower activity levels.

Table 9-15 provides data on the type of shipping container used on-site to package waste for transport to disposal facilities. Over 90 percent of the respondents reported using 55 galion drums, and approximately one out of four reported using 30 galion drums and/or nother" disposal methods (which usually include cardboard shipping containers).

In the survey, shipped waste was categorized as either dry, moist, biological, sealed, or other. Table $9-16$ presents the number of facilites reporting the shipping of waste in any of these categories. Close to 90 percent of the respondents indicated that the physical form of shipped waste is "dry". "Moist/potential free liquid" and "other" were mentioned as the next two most common waste forms ( 38 and 31 percent, respectively). 
TABLE 9-8. RADIONUCLIDES IN SHIPPED WASTE - MEDICAL

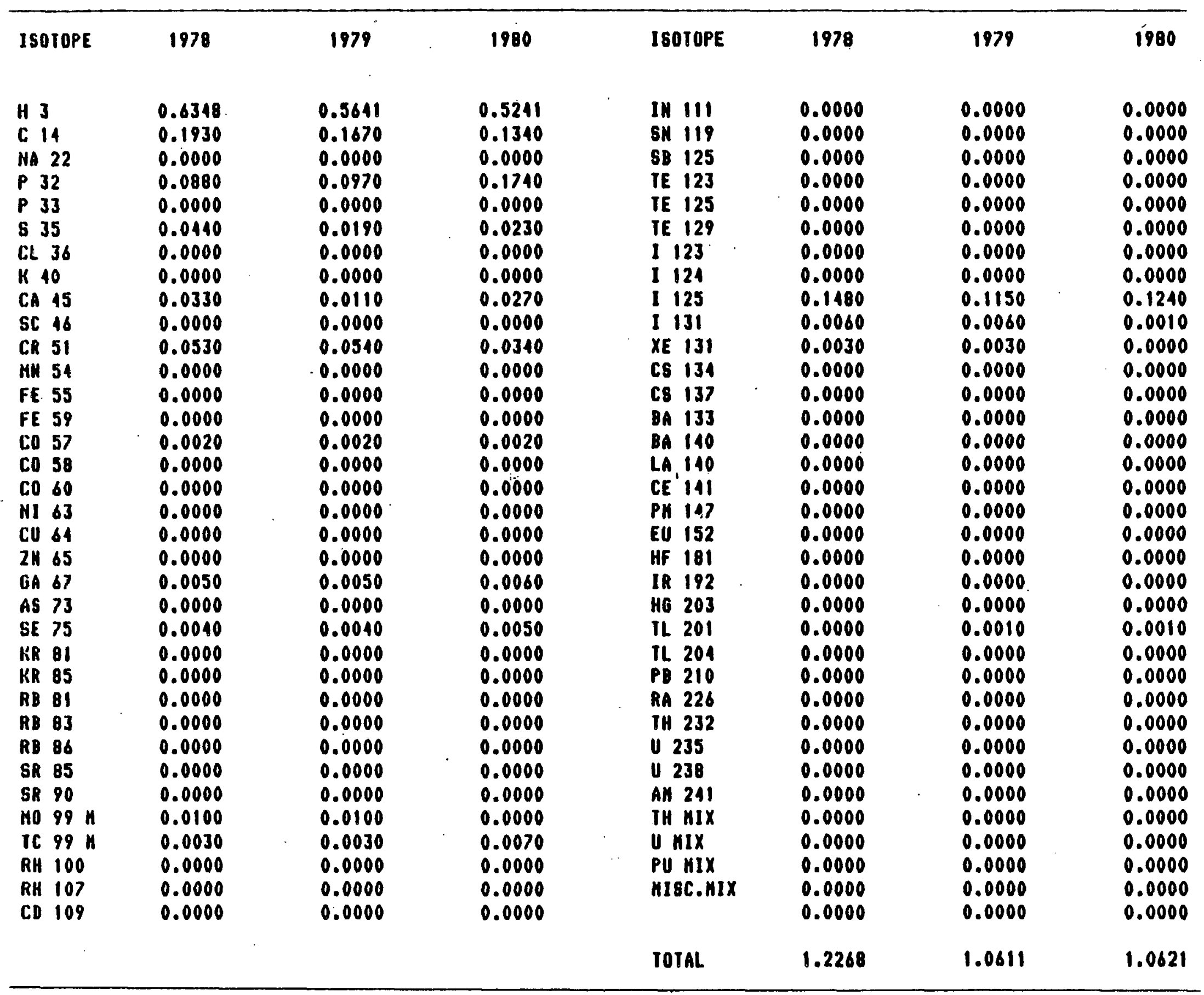


TABLE 9-9. RADIONUCLIDES IN SHIPPED WASTE - EDUCATIONAL

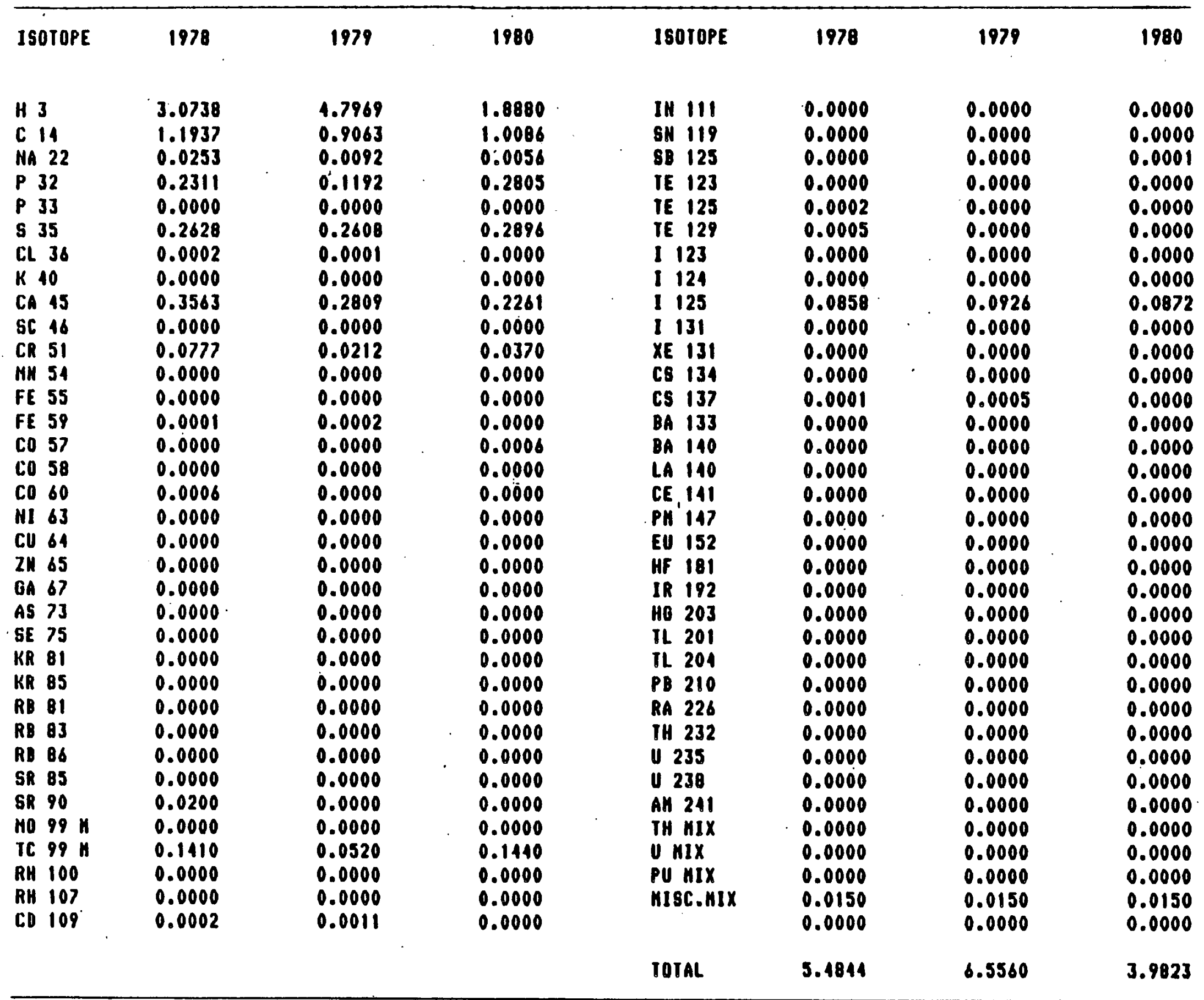


TABLE 9-10. RADIONUCLIDES IN SHIPPED WASTE - INDUSTRIAL

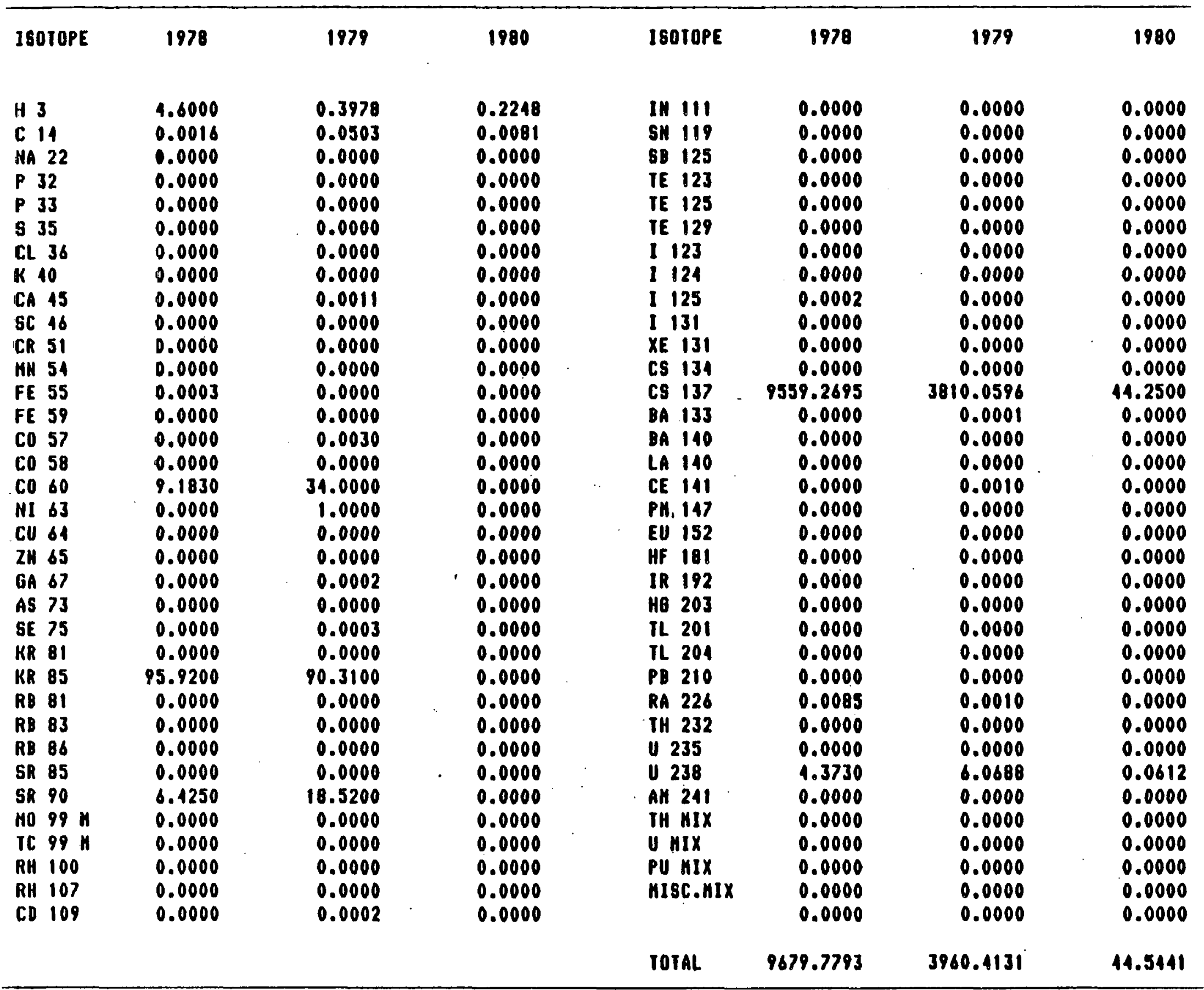


TABLE 9-11. RADIONUCLIDES IN SHIPPED WASTE - POWER REACTOR

\begin{tabular}{|c|c|c|c|c|c|c|c|}
\hline ISOTOPE & 1978 & 1979 & 1980 & ISOTOPE & 1978 & 1878 & 1980 \\
\hline 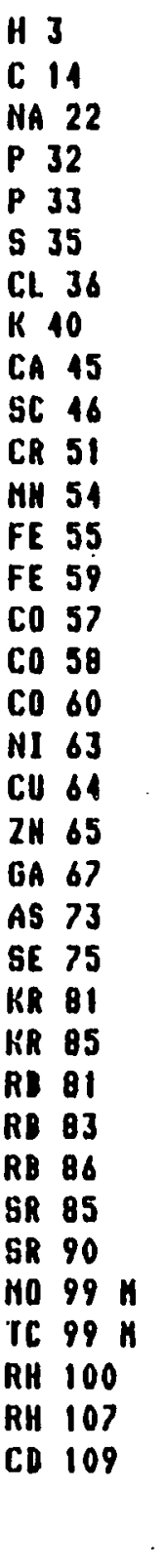 & $\begin{array}{l}0.0000 \\
0.0000 \\
0.0000 \\
0.0000 \\
0.0000 \\
3.0960 \\
0.0000 \\
0.0000 \\
0.0000 \\
0.0000 \\
0.0000 \\
0.0990 \\
0.0000 \\
0.0000 \\
0.0000 \\
0.0000 \\
0.0380 \\
0.0000 \\
0.0000 \\
0.0000 \\
0.0000 \\
0.0000 \\
0.0000 \\
0.0000 \\
0.0000 \\
0.0000 \\
0.0000 \\
0.0000 \\
0.0000 \\
0.0000 \\
0.0000 \\
0.0000 \\
0.0000 \\
0.0000 \\
0.0000\end{array}$ & $\begin{array}{l}0.0000 \\
0.0000 \\
0.0000 \\
0.0000 \\
0.0000 \\
2.3510 \\
0.0000 \\
0.0000 \\
0.0000 \\
0.0000 \\
0.0000 \\
0.2990 \\
0.0000 \\
0.0000 \\
0.0000 \\
0.0000 \\
0.1450 \\
0.0000 \\
0.0000 \\
0.0000 \\
0.0000 \\
0.0000 \\
0.0000 \\
0.0000 \\
0.0000 \\
0.0000 \\
0.0000 \\
0.0000 \\
0.0000 \\
0.0190 \\
0.0000 \\
0.0000 \\
0.0000 \\
0.0000 \\
0.0000\end{array}$ & $\begin{array}{l}0.0000 \\
0.0000 \\
0.0000 \\
0.0000 \\
0.0000 \\
25.1000 \\
0.0000 \\
0.0000 \\
0.0000 \\
0.0000 \\
0.0000 \\
2.8030 \\
0.0000 \\
0.0000 \\
0.0000 \\
0.0000 \\
1.0030 \\
0.0000 \\
0.0000 \\
0.0000 \\
0.0000 \\
0.0000 \\
0.0000 \\
0.0000 \\
0.0000 \\
0.0000 \\
0.0000 \\
0.0000 \\
0.0000 \\
1.2770 \\
0.0000 \\
0.0000 \\
0.0000 \\
0.0000 \\
0.0000\end{array}$ & 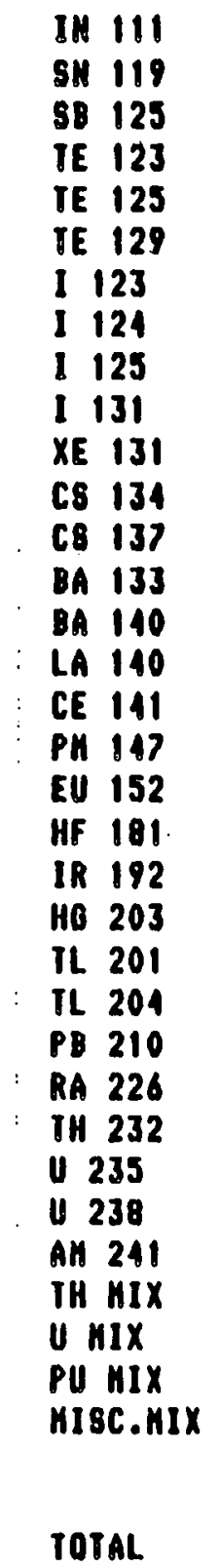 & $\begin{array}{l}0.0000 \\
0.0000 \\
0.0000 \\
0.0000 \\
0.0000 \\
0.0000 \\
0.0000 \\
0.0000 \\
0.0000 \\
0.0000 \\
0.0000 \\
0.0000 \\
0.0000 \\
0.0000 \\
0.0000 \\
0.0000 \\
0.0000 \\
0.0000 \\
0.0000 \\
0.0000 \\
0.0000 \\
0.0000 \\
0.00000 \\
0.0000 \\
0.0000 \\
0.0000 \\
0.0000 \\
0.0000 \\
0.0000 \\
0.0000 \\
0.0000 \\
0.0000 \\
0.0000 \\
0.0000 \\
0.0000 \\
3.2330\end{array}$ & $\begin{array}{l}0.0000 \\
0.0000 \\
0.0000 \\
0.0000 \\
0.0000 \\
0.0000 \\
0.0000 \\
0.0000 \\
0.0000 \\
0.0000 \\
0.0000 \\
0.0000 \\
0.0210 \\
0.0000 \\
0.0000 \\
0.0000 \\
0.0000 \\
0.0000 \\
0.0000 \\
0.0000 \\
0.0000 \\
0.0000 \\
0.0000 \\
0.0000 \\
0.0000 \\
0.0000 \\
0.0000 \\
0.0000 \\
0.0000 \\
0.0000 \\
0.0000 \\
0.0000 \\
0.0000 \\
0.0000 \\
0.0000 \\
2.8350\end{array}$ & $\begin{array}{l}0.0000 \\
0.0000 \\
0.0000 \\
0.0000 \\
0.0000 \\
0.0000 \\
0.0000 \\
0.0000 \\
0.0000 \\
0.0000 \\
0.0000 \\
0.0000 \\
0.2590 \\
0.0000 \\
0.0000 \\
0.0000 \\
0.0000 \\
0.0000 \\
0.0000 \\
0.0000 \\
0.0000 \\
0.0000 \\
0.0000 \\
0.0000 \\
0.0000 \\
0.0000 \\
0.0000 \\
0.0000 \\
0.0000 \\
0.0000 \\
0.0000 \\
0.0000 \\
0.0000 \\
0.0000 \\
0.0000 \\
30.8420\end{array}$ \\
\hline
\end{tabular}


TABLE 9-12. RADIONUCLIDES IN SHIPPED WASTE - GOVERNMENTAL

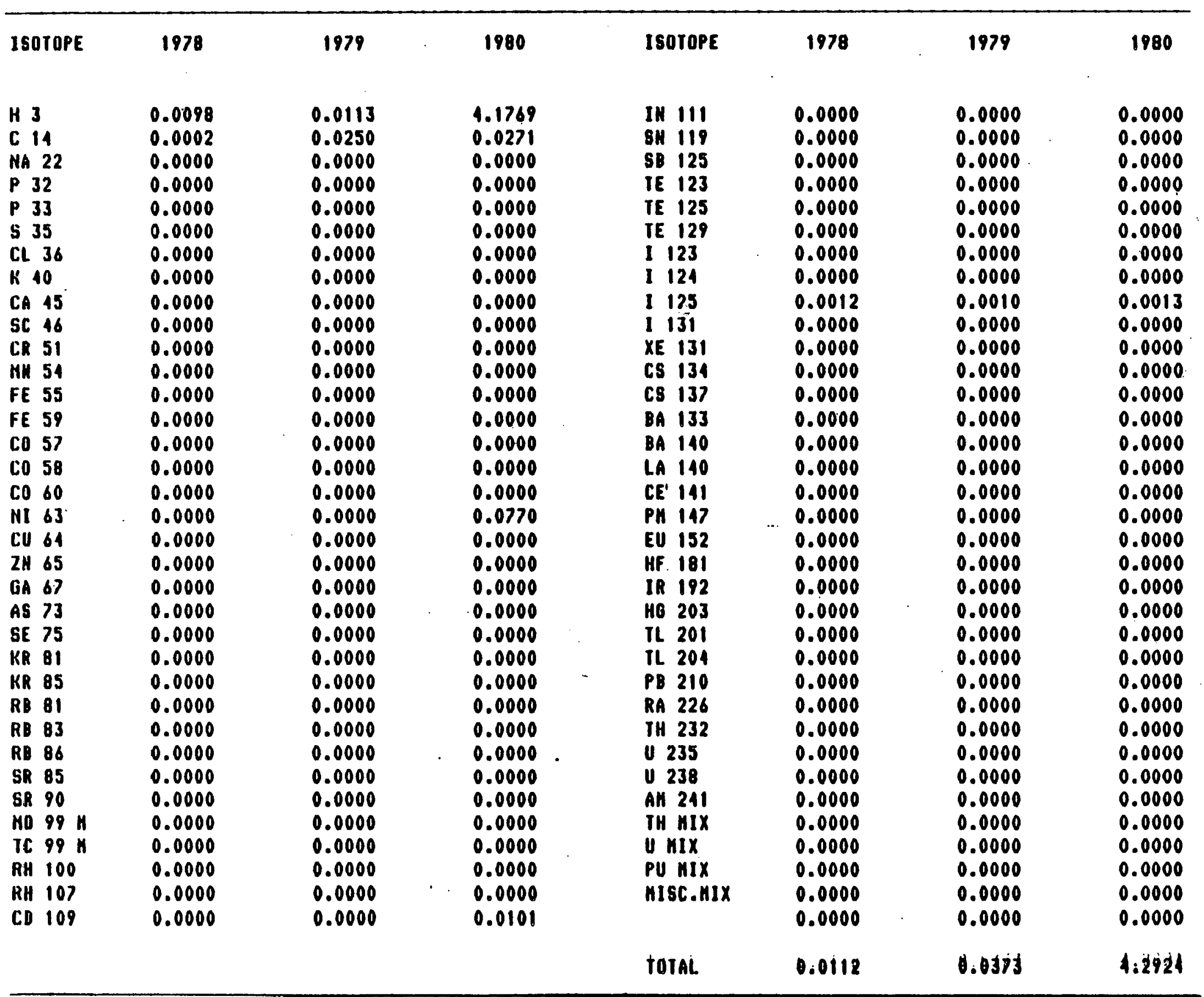


TABLE 9-13. RADTONUCLIDES IN SHIPPED WASTE - TOTAL

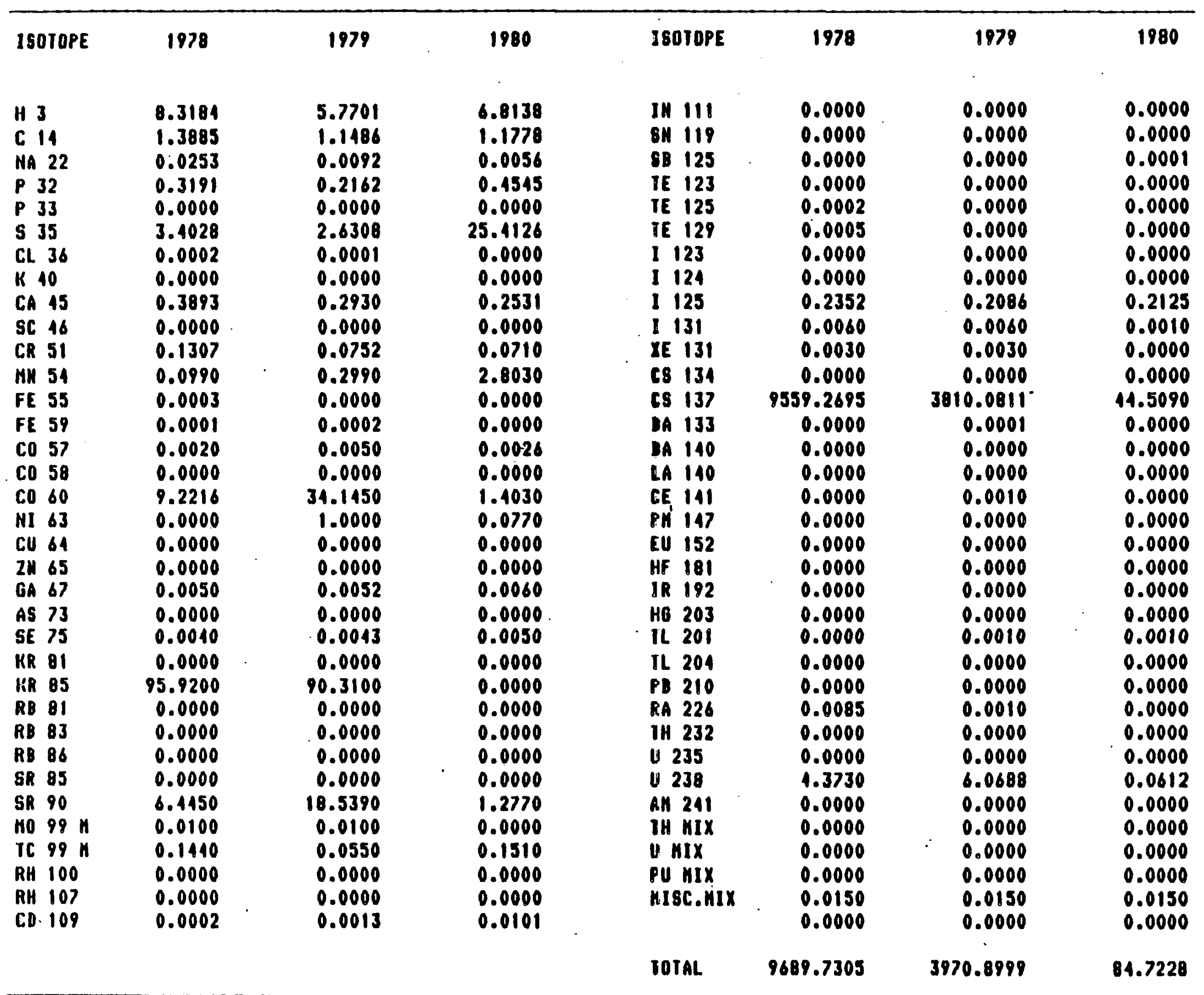


TABLE 9-14. ONSITE PROCESSING OF WASTE

\begin{tabular}{|c|c|c|c|c|c|c|c|c|c|c|c|c|c|}
\hline \multirow{2}{*}{$\begin{array}{r}\text { Type of } \\
\text { Facility }\end{array}$} & \multirow{2}{*}{$\begin{array}{c}\text { Number of } \\
\text { Respondents }\end{array}$} & \multicolumn{2}{|c|}{ None } & \multicolumn{2}{|c|}{$\begin{array}{l}\text { Mechan Ical } \\
\text { Compaction }\end{array}$} & \multicolumn{2}{|c|}{ Incineration } & \multicolumn{2}{|c|}{$\begin{array}{l}\text { 8olldification/ } \\
\text { Evaporation }\end{array}$} & \multicolumn{2}{|c|}{ Absorption } & \multicolumn{2}{|c|}{ Other } \\
\hline & & Number & Percent & Number & Percent & Number & Percent & Number & Percent & Number & Percent & Number & Percent \\
\hline Medical & 7 & 1 & 14.29 & 1 & 14.29 & 2 & 28.57 & 0 & 0.00 & 2 & 28.57 & 3 & 42.86 \\
\hline Education & 8 & 4 & 50.00 & $\mathbf{0}$ & 0.00 & 2 & 25.00 & 2 & 25.00 & 4 & 50.00 & 1 & 12.50 \\
\hline Industrial & 12 & 6 & 50.00 & 3 & 25.00 & 1 & 8.33 & 2 & 16.67 & 3 & 25.00 & 0 & 0.00 \\
\hline Power Reactor & 2 & 0 & 0.00 & 2 & 100.00 & 0 & 0.00 & 2 & 100.00 & 0 & 0.00 & 1 & 50.00 \\
\hline Government & 3 & 0 & 0.00 & 2 & 66.67 & 1 & 33.33 & 1 & 33.33 & 2 & 66.67 & 0 & 0.00 \\
\hline TOTAL & 32 & 11 & 34.38 & 8 & 25.00 & 6 & 18.75 & 7 & 21.88 & 11 & 34.38 & 5 & 15.63 \\
\hline
\end{tabular}


TABLE 9-15. 'SHIPPING CONTAINER USED

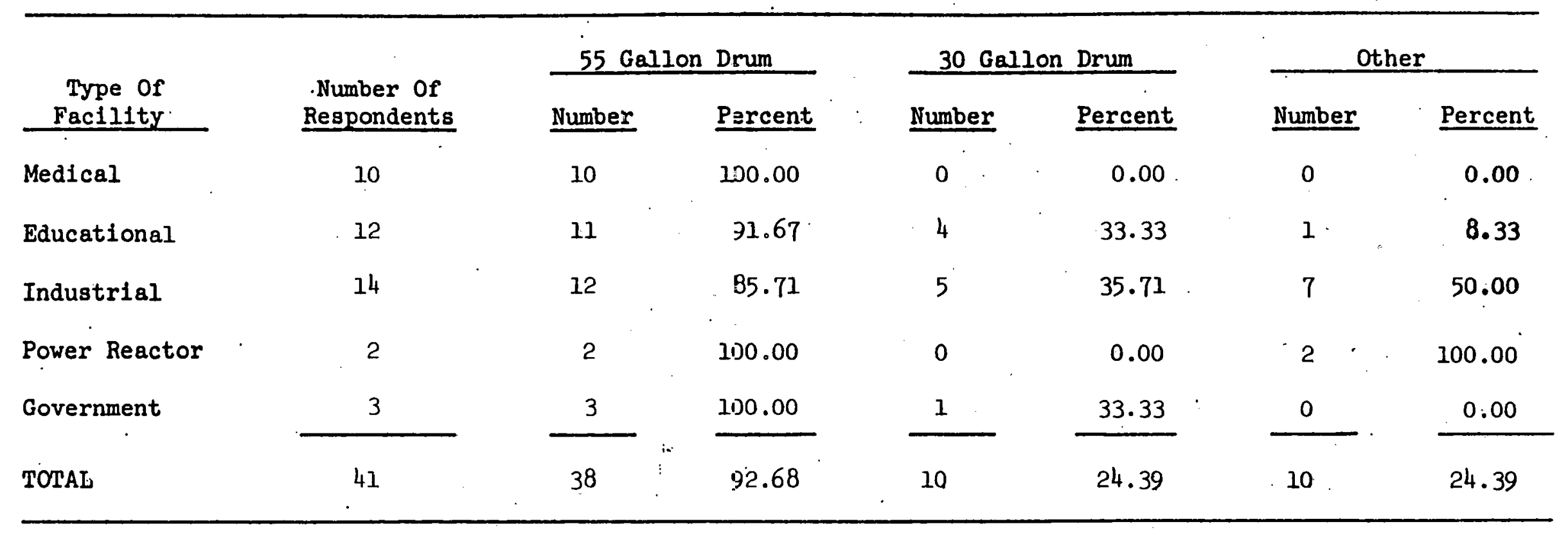


TABLE 9-16. PHYSICAL FORM OF SHIPPED WASTE

\begin{tabular}{|c|c|c|c|c|c|c|c|c|c|c|c|}
\hline \multirow{2}{*}{$\begin{array}{r}\text { Type of } \\
\text { Facility }\end{array}$} & \multirow{2}{*}{$\begin{array}{l}\text { Number of } \\
\text { Respondents }\end{array}$} & \multicolumn{2}{|c|}{ Dry } & \multicolumn{2}{|c|}{$\begin{array}{l}\text { Molit/Potential } \\
\text { Free Liquid } \\
\end{array}$} & \multicolumn{2}{|c|}{$\begin{array}{l}\text { Biological } \\
\text { Waste }\end{array}$} & \multicolumn{2}{|c|}{ Sealed Sources } & \multicolumn{2}{|c|}{ Other } \\
\hline & & Number & Percent & Number & Percent & Number & Percent & Number & Percent & Number & Percent \\
\hline Medlcal & 7 & 5 & 71.43 & 3 & 42.86 & 0 & 0.00 & 3 & 42.86 & 2 & 28.57 \\
\hline Educational & 8 & 8 & 100.00 & 2 & 25.00 & 3 & $37: 50$ & 1 & 12.50 & 4 & 50.00 \\
\hline Industriel & $12^{\circ}$ & 10 & $83.33^{\circ}$ & 6 & 50.00 & 1 & 8.33 & 5 & 41.67 & 3 & 25.00 \\
\hline Power Reactor & 2 & 2 & 100.00 & 1 & 50.00 & 0 & 0.00 & 0 & 0.00 & 1 & 50.00 \\
\hline Government & 3 & 3 & 100.00 & $\therefore 0$ & 0.00 & . 0 & 0.00 & 0 & 0.00 & 0 & 0.00 \\
\hline TOTAL & 32 & 28 & 87.50 & 12 & 37.50 & 4 & 12.50 & 9 & 28.13 & 10 & 31.25 \\
\hline
\end{tabular}


APPENDIX A

IIST OF NRC LICENSEES 


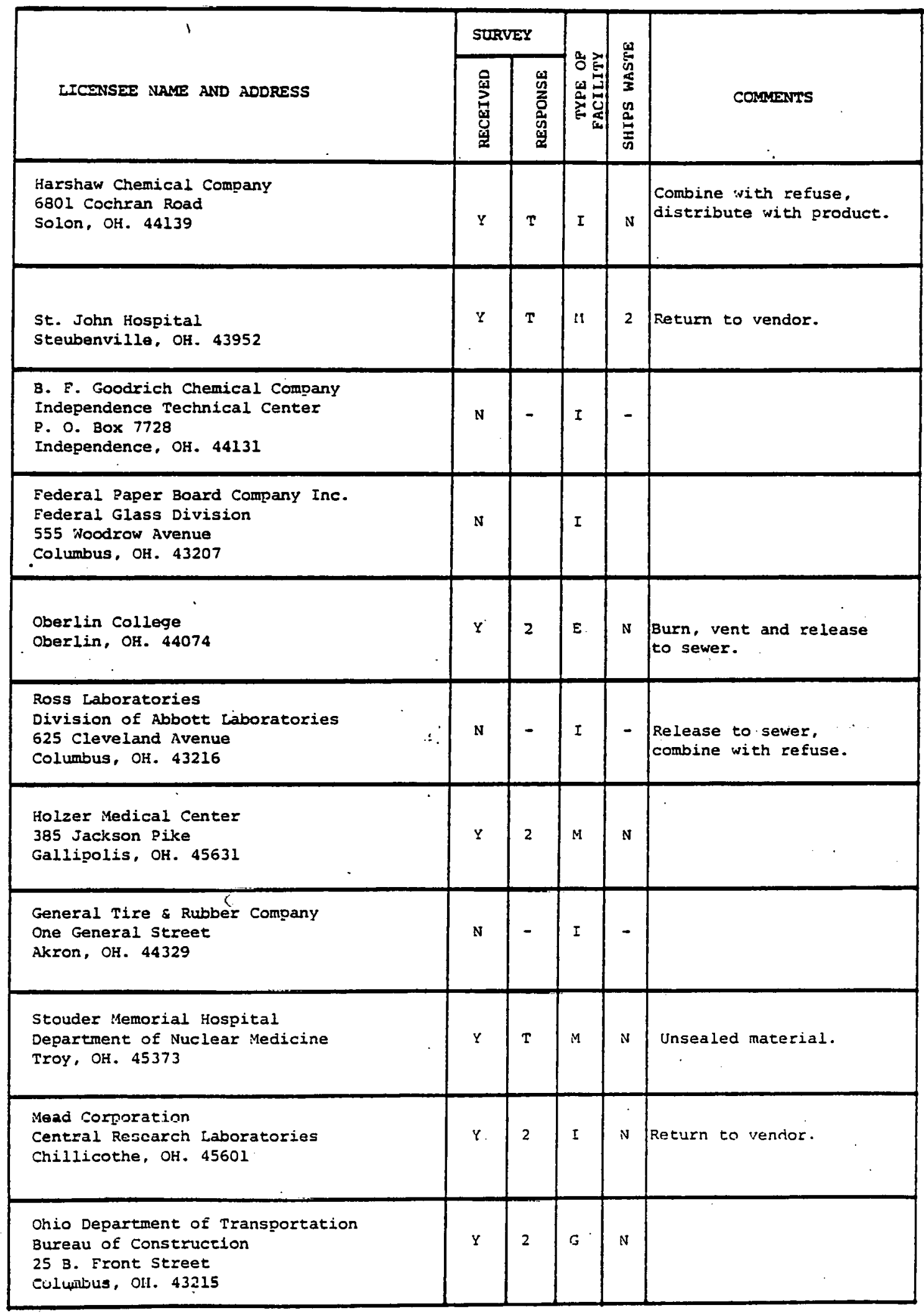




\begin{tabular}{|c|c|c|c|c|c|}
\hline \multirow[b]{2}{*}{ LICENSEE NAME AND ADDRESS } & \multicolumn{2}{|c|}{ SURVEY } & \multirow{2}{*}{ 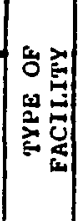 } & \multirow{2}{*}{ 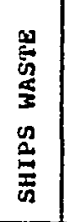 } & \multirow[b]{2}{*}{ COMMENTS } \\
\hline & 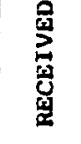 & 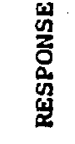 & & & \\
\hline $\begin{array}{l}\text { Medusa Cement Company } \\
\text { Division of Medusa Corporation } \\
\text { ?. O. Box } 5668 \\
\text { Cleveland, OH. } 44101\end{array}$ & $\mathbf{N}$ & - & I & - & \\
\hline $\begin{array}{l}\text { Veterans Administration Medical Center } \\
4100 \text { Nest Third Street } \\
\text { Dayton, OH. } 45428\end{array}$ & $\mathbf{Y}$ & 2 & $\dot{M}$ & $\mathbf{N}$ & $\begin{array}{l}\text { Sealed and unsealed } \\
\text { sources used. }\end{array}$ \\
\hline $\begin{array}{l}\text { Suburban Community Hospital } \\
\text { Dept. of Radiology \& Nuclear Medicine } \\
4180 \text { warrensville Center Road } \\
\text { Warrensville Height, OH. } 44122\end{array}$ & $Y$ & 2 & 14 & $\mathrm{~N}$ & Vent, return to vender. \\
\hline $\begin{array}{l}\text { IMC Chemical Group Inc. } \\
\text { Middle Road, } \\
\text { Ashtabula, OH. } 44004\end{array}$ & $\mathbf{N}$ & - & I & - & \\
\hline $\begin{array}{l}\text { Akron General Medical Center } \\
400 \text { Wabash Avenue. } \\
\text { Akron, OH. } 44307\end{array}$ & 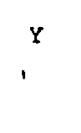 & $\mathbf{T}$ & $M$ & $\mathbf{N}$ & $\begin{array}{l}\text { Sealed, unsealed sources } \\
\text { uged. Decay to background } \\
\text { and combine with refuse. }\end{array}$ \\
\hline $\begin{array}{l}\text { Grant Hospital } \\
\text { Depts. of Pathology \& Radiology } \\
309 \text { East State Street } \\
\text { Columbus, OH. } 43215\end{array}$ & $\mathbf{Y}$ & 2 & $\mathbf{M}$ & $\mathbf{N}$ & \\
\hline $\begin{array}{l}\text { Deaconess Hospital } \\
\text { Radiology Department } \\
311 \text { Straight St. \& Clifton } \\
\text { Cincinnati, OH. } 45219\end{array}$ & $Y$ & 2 & $M$ & $\mathbf{N}$ & Return to vendor. \\
\hline $\begin{array}{l}\text { Richardson-Merrell Inc. } \\
\text { Merrell-National Laboratories } \\
\text { lio E. Amity Road } \\
\text { Cincinnati, OH. } 45215\end{array}$ & $\mathbf{N}$ & - & $I$ & - & - \\
\hline $\begin{array}{l}\text { Cleveland Metropolitan General Hospital } \\
\text { Department of Radiology } \\
3395 \text { Scranton Road } \\
\text { Cleveland, OH. } 44109\end{array}$ & $\mathbf{N}$ & - & $M$ & - & \\
\hline $\begin{array}{l}\text { Christ Hospital } \\
2139 \text { Auburn Avenue } \\
\text { Cincinnati, OH. } 45219\end{array}$ & $\mathbf{N}$ & - & $\mathrm{M}$ & - & \\
\hline $\begin{array}{l}\text { Elyria Memorial Hospital } \\
630 \text { East River Street } \\
\text { Elyria, OH. } 44035 \\
\text {. }\end{array}$ & $Y$ & I & $\because$ & N & Sealed, unsealed sources. \\
\hline
\end{tabular}




\begin{tabular}{|c|c|c|c|c|c|}
\hline & sur & & & & \\
\hline LICENSEE NAME AND ADDRESS & 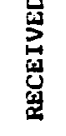 & 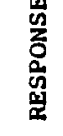 & 采司 & 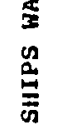 & COMMENTS \\
\hline $\begin{array}{l}\text { Massillon Steel Casting Company } \\
\text { Research, Development \& Inspection Dept. } \\
577 \text { Oberlin Ave. } 5 . w . \\
\text { Massillon, OH. } 44646\end{array}$ & N & - & I & - & \\
\hline $\begin{array}{l}\text { Southwestern Portland Cement Co. } \\
506 \text { East Xenia Drive } \\
\text { Fairborn, OH. } 45324\end{array}$ & $\eta$ & 2 & $\mathbf{T}$ & $N$ & Return to vendor. \\
\hline $\begin{array}{l}\text { U. S. Industrial Chemical Company } \\
1275 \text { Section Road } \\
\text { Clncinnati. OH. } 45237\end{array}$ & $\mathbf{N}$ & - & I & - & \\
\hline $\begin{array}{l}\text { Herron Testing Laboratories } \\
\text { Crobaugh Division } \\
540 \text { S East Schaaf Road } \\
\text { Cleveland. OH. } 44131\end{array}$ & & & I & & \\
\hline $\begin{array}{l}\text { Farrel1-Cheek Steel Company } \\
\text { Inspection Department } \\
706 \text { Lane Street } \\
\text { Sandusky, OH. } 44870\end{array}$ & N & - & I & - & \\
\hline $\begin{array}{l}\text { Sawyer Research Droduct Inc. } \\
\text { Quartz Production Department } \\
35400 \text { Lakeland Blvd. } \\
\text { Eastlake, OH. } 44094\end{array}$ & $y$ & 2 & I & N & Return to vendor. \\
\hline $\begin{array}{l}\text { B. F. Goodrich Research Center } \\
9921 \text { Brecksville Road } \\
\text { Rrer.ksville. OH. } 44141\end{array}$ & $\mathrm{~N}$ & - & I & - & \\
\hline $\begin{array}{l}\text { Fort Hamilton Hospital } \\
630 \text { Easton Avenue } \\
\text { Hamilton, OH. } 45013\end{array}$ & $Y$ & $\mathbf{T}$ & il & $N$ & \\
\hline $\begin{array}{l}\text { St. Anthony Hospital } \\
\text { 1450 Hawthorne Avenue } \\
\text { Columbus, OH. } 43203\end{array}$ & $y$ & 2 & it & $\mathrm{N}$ & $\begin{array}{l}\text { Last commercial shipment } \\
\text { in } 1975 .\end{array}$ \\
\hline $\begin{array}{l}\text { Babcock \& Wilcox Co. } \\
\text { B \& N Construction Company } \\
3333 \text { Copley Road } \\
\text { Copley, OH. } 44321\end{array}$ & $\because$ & 2 & I & $N$ & Return to vendor. \\
\hline $\begin{array}{l}\text { Fairview General Hospital } \\
\text { 13101 Lorain Avenue } \\
\text { Cleveland, OH. } 44111\end{array}$ & $Y$ & 2 & iq & $\mathrm{N}$ & $\begin{array}{l}\text { Return to yendor. } \\
\text { Deoay to backgrominn. }\end{array}$ \\
\hline
\end{tabular}




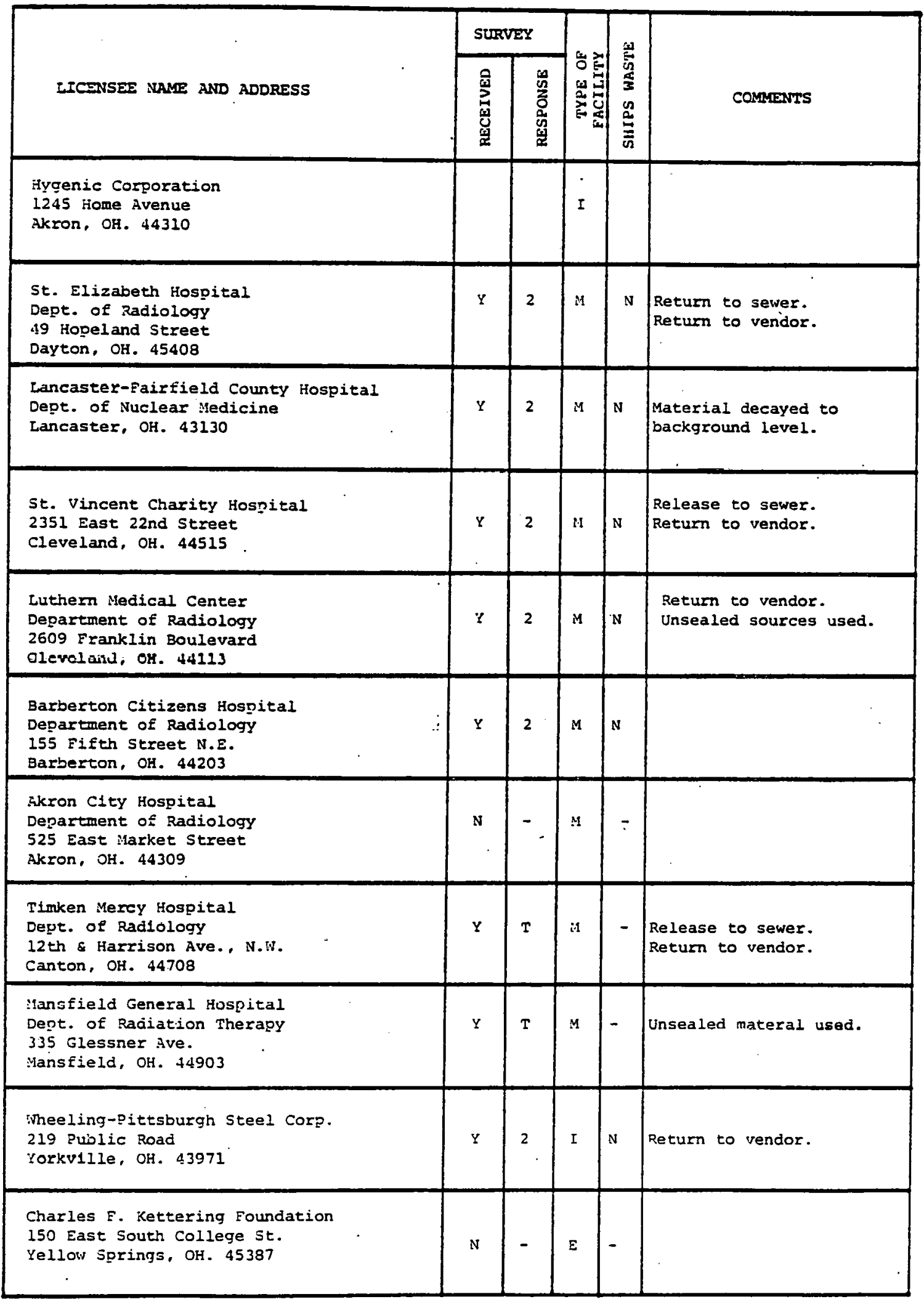




\begin{tabular}{|c|c|c|c|c|c|}
\hline \multirow[b]{2}{*}{ LICENSEE NAME AND ADDRESS } & \multicolumn{2}{|c|}{ SURVEY } & \multirow{2}{*}{ 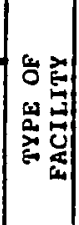 } & \multirow{2}{*}{ 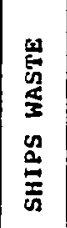 } & \multirow[b]{2}{*}{ COMAENTS } \\
\hline & 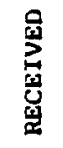 & 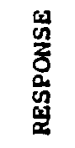 & & & \\
\hline $\begin{array}{l}\text { Proctor \& Gamble Co. } \\
\text { Miami Valley Laboratories Research \& } \\
\text { Development Dept. } \\
\text { P. O. Box } 39175 \\
\text { Cincinnati, OH. } 45247\end{array}$ & $\mathbf{N}$ & - & I & - & . \\
\hline $\begin{array}{l}\text { Providence Hospital } \\
\text { Dept. of Radiology } \\
1912 \text { South Hayes Ave. } \\
\text { Sandusky, OH. } 44870\end{array}$ & $Y$ & $\mathbf{T}$ & M & $\mathrm{N}$ & Unsealed sources used. \\
\hline $\begin{array}{l}\text { Toledo Hospital } \\
2142 \text { North Cove Blvd. } \\
\text { Toledo, OH. } 43606\end{array}$ & $\mathrm{Y}$ & 2 & is & $\mathbf{N}$ & \\
\hline $\begin{array}{l}\text { Gladstone Lais. Inc. } \\
\text { lo34 Woodrow St. } \\
\text { Cincinnati, OH. } 45204\end{array}$ & v & - & I & - & \\
\hline $\begin{array}{l}\text { Owen-Illinois Inc. } \\
\text { Corporate Engineering Dept. } \\
1700 \text { North Westwood Ave. } \\
\text { Toledo, OH. } 43607\end{array}$ & $\mathbf{N}$ & - & $I$ & - & . \\
\hline $\begin{array}{l}\text { Health Education and Welfare } \\
\text { Dept. of Public Health Service (FDA) } \\
1090 \text { Tusculum Ave. } \\
\text { Cincinnati, OH. } 45226\end{array}$ & N & 1 & $G$ & $Y$ & lo08 dry solids shipned. \\
\hline $\begin{array}{l}\text { Aultman Hospital } \\
\text { Radiology Dept. } \\
2600 \text { 6th St. S.w. } \\
\text { Canton, UH. } 44710\end{array}$ & $\because$ & $\mathbf{T}$ & $M$ & $\mathbf{N}$ & $\begin{array}{l}\text { Unsealed sources used. } \\
\text { Decay to background. }\end{array}$ \\
\hline $\begin{array}{l}\text { Miami University } \\
\text { Oxford, OH. } 45056\end{array}$ & $y$ & 1 & $E$ & $Y$ & Liquid scintillation fluid. \\
\hline $\begin{array}{l}\text { Bay View Hospital } \\
\text { Dept. of Nuclear Medicino } \\
23200 \text { Lake Road } \\
\text { Bay Village, OH. } 44140\end{array}$ & $\mathrm{~N}$ & - & is & - & - \\
\hline $\begin{array}{l}\text { Ashtabula General Hospital } \\
\text { Dept. of Radiology } \\
2240 \text { Lake Ave. } \\
\text { Ashtabula, OH. } 44004\end{array}$ & $\because$ & 2 & $M$ & $\mathrm{~N}$ & $\begin{array}{l}\text { Primarily unsealed } \\
\text { materials used. }\end{array}$ \\
\hline $\begin{array}{l}\text { General Motors Corp. } \\
\text { Terex Division } \\
\text { Plant No. } 4 \\
\text { Hudison, OH. } 44236\end{array}$ & $\mathrm{~N}$ & - & I & - & \\
\hline
\end{tabular}




\begin{tabular}{|c|c|c|c|c|c|}
\hline & SUF & & & & \\
\hline LICENSEE NAME AND ADDRESS & 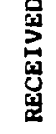 & 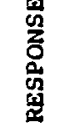 & 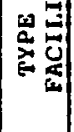 & 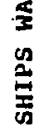 & COMRIENTSS \\
\hline $\begin{array}{l}\text { iuron Road Hospital } \\
13951 \text { Terrace Road } \\
\text { East Cleveland, OH. } 44112\end{array}$ & $\mathbf{N}$ & - & $\mathrm{M}$ & - & \\
\hline $\begin{array}{l}\text { Marathon oil Co. } \\
539 \text { South Main St. } \\
\text { Findlay, OH. } 45840\end{array}$ & $\mathbf{N}$ & - & $\mathbf{I}$ & - & \\
\hline $\begin{array}{l}\text { Midland-Ross Corp. } \\
\text { Unitcast Division } \\
\text { Toledo, OH. } 43605\end{array}$ & $\mathbf{N}$ & - & I & $\rightarrow$ & \\
\hline $\begin{array}{l}\text { St. Elizabeth Hospital } \\
\text { Dept. of Radiology } \\
\text { lo44 Belmont Ave. } \\
\text { Youngstown, OH. } 44505\end{array}$ & $\mathbf{Y}$ & 2 & $\mathbf{M}$ & $\mathbf{N}$ & $\cdots$ \\
\hline $\begin{array}{l}\text { Goodyear Aerospace Corp. } \\
1210 \text { Massillon Rd. } \\
\text { Akron. OH. } 44315\end{array}$ & $\mathbf{Y}$ & 1 & 1 & $Y$ & \\
\hline $\begin{array}{l}\text { Lakewood Hospital } \\
\text { Nuclear Medicine Dept. } \\
14519 \text { Detroit Ave. } \\
\text { Lakewood, OH. } 44107\end{array}$ & $\mathbf{N}$ & - & is & - & · \\
\hline $\begin{array}{l}\text { St. Vincent Hospital \& Medical Center } \\
\text { Radiology Dept. } \\
2213 \text { Cherry St. } \\
\text { Toledo, OH. } 43608\end{array}$ & $Y$ & $\mathbf{z}$ & $M$ & $\mathbf{N}$ & Unsealed materials used. \\
\hline $\begin{array}{l}\text { Ohio University } \\
\text { College of Arts and Sciences } \\
\text { Athens, OH. } 45701\end{array}$ & $\boldsymbol{Y}$ & 1 & $\varepsilon$ & $Y$ & Unsealed material. \\
\hline $\begin{array}{l}\text { Standard Oil Co. (OHIO) } \\
\text { Research Department } \\
4440 \text { Warrensville Center Road } \\
\text { Cleveland, OH. } 44128\end{array}$ & $Y$ & 2 & 1 & $\mathrm{~N}$ & \\
\hline $\begin{array}{l}\text { Good Samaritan Hospital and health Center } \\
222 \text { Philadelphia Drive } \\
\text { Dayton, OH. } 45406\end{array}$ & $Y$ & 1 & $M$ & $Y$ & . \\
\hline $\begin{array}{l}\text { Mercy Medical Center } \\
\text { Isotopes Laboratory Dent. of Radiology } \\
1343 \text { North Fountain ive. } \\
\text { Springfield, OH. } 45501\end{array}$ & $\mathbf{Y}$ & 2 & $\mathbf{M}$ & $\mathbb{N}$ & Release to sewer. \\
\hline
\end{tabular}




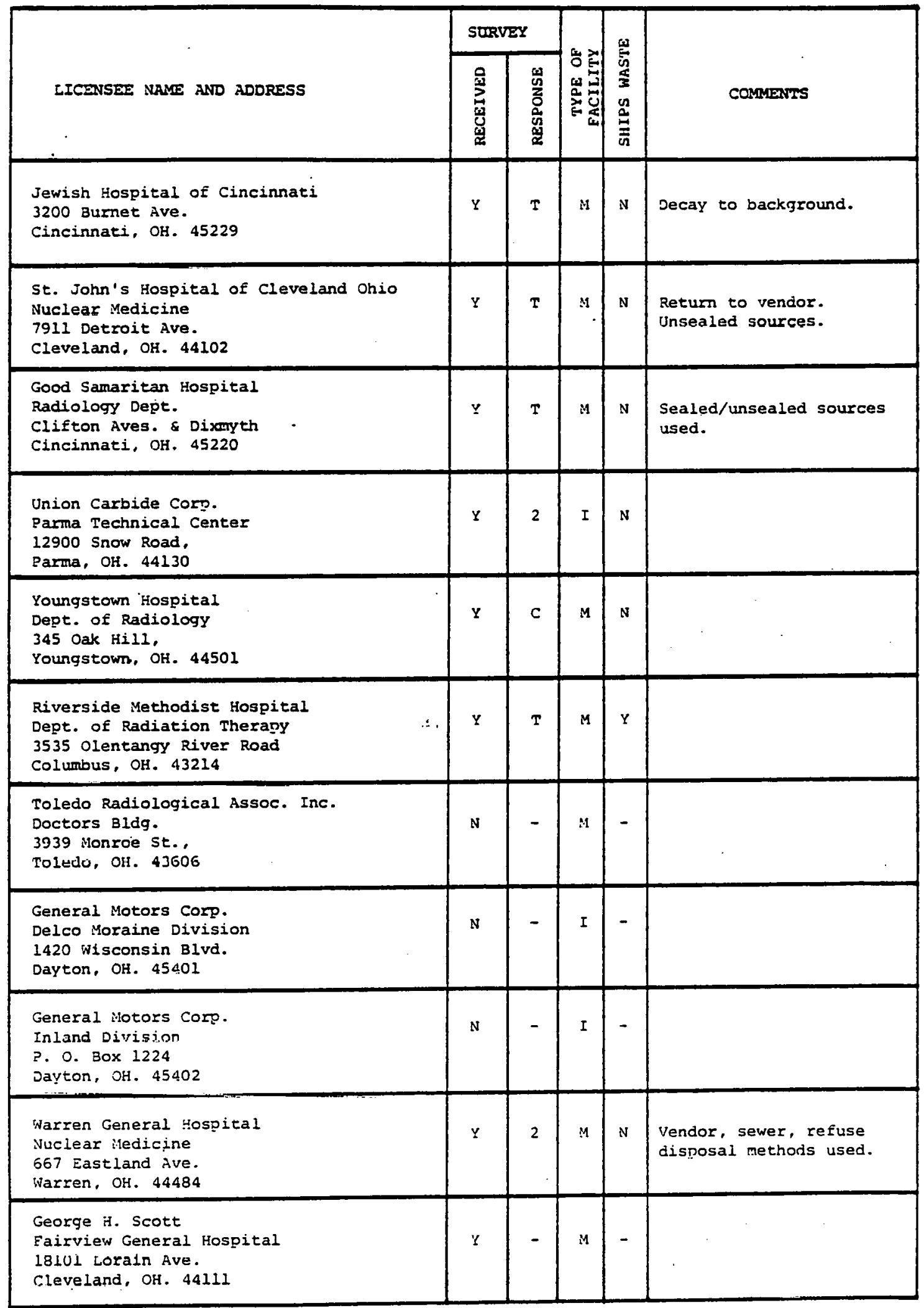




\begin{tabular}{|c|c|c|c|c|c|}
\hline . & SURT & & & & \\
\hline LICDNSEE NAME AND ADDRESS & 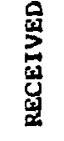 & 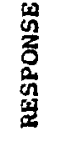 & 象要 & 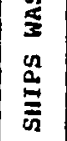 & COMMENTSS \\
\hline $\begin{array}{l}\text { Benton Ridge Telephone co. } \\
\text { P. O. Box } 180 \\
\text { Benton Ridge, OH. } 45816\end{array}$ & $\mathbb{N}$ & - & I & - & \\
\hline $\begin{array}{l}\text { Wallace-Murray Corp. } \\
\text { Eljer Plumbingware Division } \\
921 \text { s. Ellsworth Ave. } \\
\text { Salem, OH. } 44460\end{array}$ & $y$ & 2 & $I$ & N & \\
\hline $\begin{array}{l}\text { Eastern Well Surveys, Inc. } \\
433 \text { South Grant Street, } \\
\text { Wooster, OH. } 44691\end{array}$ & $Y$ & 2 & I & N & \\
\hline $\begin{array}{l}\text { City of Toledo } \\
\text { Division of Water Reclamation } \\
\text { Bay View Park } \\
\text { Toledo, OH. } 43611\end{array}$ & $y$ & 2 & $G$ & $\mathrm{~N}$ & Vendor. \\
\hline $\begin{array}{l}\text { Bowling Green State University } \\
\text { Bowling Green, OH. } 43403\end{array}$ & $\mathbf{Y}$ & 1 & $\varepsilon$ & $y$ & Unsealed material. \\
\hline $\begin{array}{l}\text { Armco Steel Corp. } \\
\text { Marion Works } \\
912 \text { Cheney Ave. } \\
\text { Marion, OH. } 43302\end{array}$ & $\therefore$ & - & I & $1-$ & \\
\hline $\begin{array}{l}\text { Dow Chemical USA } \\
\text { Hanging Rock Plant } \\
\text { Ironton, OH. } 45638\end{array}$ & N & - & I & - & . \\
\hline $\begin{array}{l}\text { Huron Lime Co. } \\
\text { loo Meeker St. } \\
\text { Huron, OH. } 44839\end{array}$ & N & - & I & - & . \\
\hline $\begin{array}{l}\text { Glyco Chemicals Inc, } \\
679 \text { Hardy Road } \\
\text { Painesville, OH. } 44077\end{array}$ & $\mathrm{~N}$ & - & I & - & \\
\hline $\begin{array}{l}\text { Ohio Medical Products } \\
\text { Ohio Medical Products Division } \\
1177 \text { Marquette St. } \\
\text { Cleveland, OH. } 44114\end{array}$ & v & - & I & - & . \\
\hline $\begin{array}{l}\text { Marietta Memorial Hosnital } \\
\text { Matthew \& Eerguson Sts. } \\
\text { Marietta, OH. } 45750\end{array}$ & N & - & $\because \mathrm{i}$ & - & \\
\hline
\end{tabular}




\begin{tabular}{|c|c|c|c|c|c|}
\hline & SUR & & & & \\
\hline LICENSEE NANE AND ADDRESS & 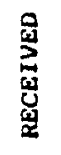 & $\begin{array}{l}\frac{1}{0} \\
\frac{1}{2} \\
\frac{0}{02} \\
\frac{2}{2}\end{array}$ & $\mid \begin{array}{cc}0 & 0 \\
0 & 0 \\
0 & 0 \\
0 & 0 \\
0 & 0\end{array}$ & 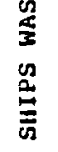 & COMMIENTS \\
\hline $\begin{array}{l}\text { St. Rita's Hospital } \\
730 \text { West Market Street } \\
\text { Lima, OH. } 45801\end{array}$ & $y$ & $\mathbf{T}$ & $\mathrm{M}$ & $\mathbf{N}$ & Return to vendor. \\
\hline $\begin{array}{l}\text { Pfizer Inc. } \\
\text { Cr.85 \& Sr. } 300 \\
\text { Gibsonburg, OH. } 43431\end{array}$ & $\mathbf{Y}$ & 2 & $I$ & $\mathrm{~N}$ & Return to vendor. \\
\hline $\begin{array}{l}\text { Monsanto Company } \\
\text { River Road } \\
\text { Addyston, OH. } 45001\end{array}$ & $\mathrm{~N}$ & - & $F$ & - & \\
\hline $\begin{array}{l}\text { Christian Holmes } \\
\text { Radiology Dept. } \\
\text { Eden \& Bethesda ives. } \\
\text { Cincinnati. OH. } 45219\end{array}$ & $\mathbf{N}$ & - & $\mathrm{i}$ & - & \\
\hline $\begin{array}{l}\text { Brentwood Hospital } \\
4110 \text { Warrengville Center Road } \\
\text { Cleveland, Oft. } 44122\end{array}$ & $y$ & 2 & $M$ & $\mathbf{N}$ & $\begin{array}{l}\text { Return to vendor. } \\
\text { Decay to background. }\end{array}$ \\
\hline $\begin{array}{l}\text { Barnebey-Cheney Co. } \\
835 \text { N. Cassady Ave. } \\
\text { Columbus, OH. } 43219\end{array}$ & $\mathrm{~s}$ & - & $I$ & - & \\
\hline $\begin{array}{l}\text { State of Ohio Disaster Services Agency } \\
\text { P. O. Box } 660 \\
2825 \text { w. Granville Road } \\
\text { Northington, OH. } 43095\end{array}$ & $\mathrm{~N}$ & - & $G$ & - & \\
\hline $\begin{array}{l}\text { United States steel Corp. } \\
\text { Lorain Works } \\
1807 \text { East 23th St. } \\
\text { Lorain, OH. } 44055\end{array}$ & ? & 2 & I & $\mathrm{N}$ & Return to vendor. \\
\hline $\begin{array}{l}\text { Ottawa Park Medical Group } \\
2361 \text { Bancroft at Evansdale } \\
\text { Toledo, OH. } 43607\end{array}$ & $\mathrm{~N}$ & - & $M$ & - & \\
\hline $\begin{array}{l}\text { College of Wooster } \\
\text { Dept. of Biology } \\
\text { Wooster, OH. } 44691\end{array}$ & $N$ & - & E & - & \\
\hline $\begin{array}{l}\text { Dayton Power \& Light Co. } \\
\text { Courthouse Plaza Southwest } \\
\text { P. O. Box } 1247 \\
\text { Dayton, OH. } 45401\end{array}$ & $v$ & - & $G$ & - & \\
\hline
\end{tabular}




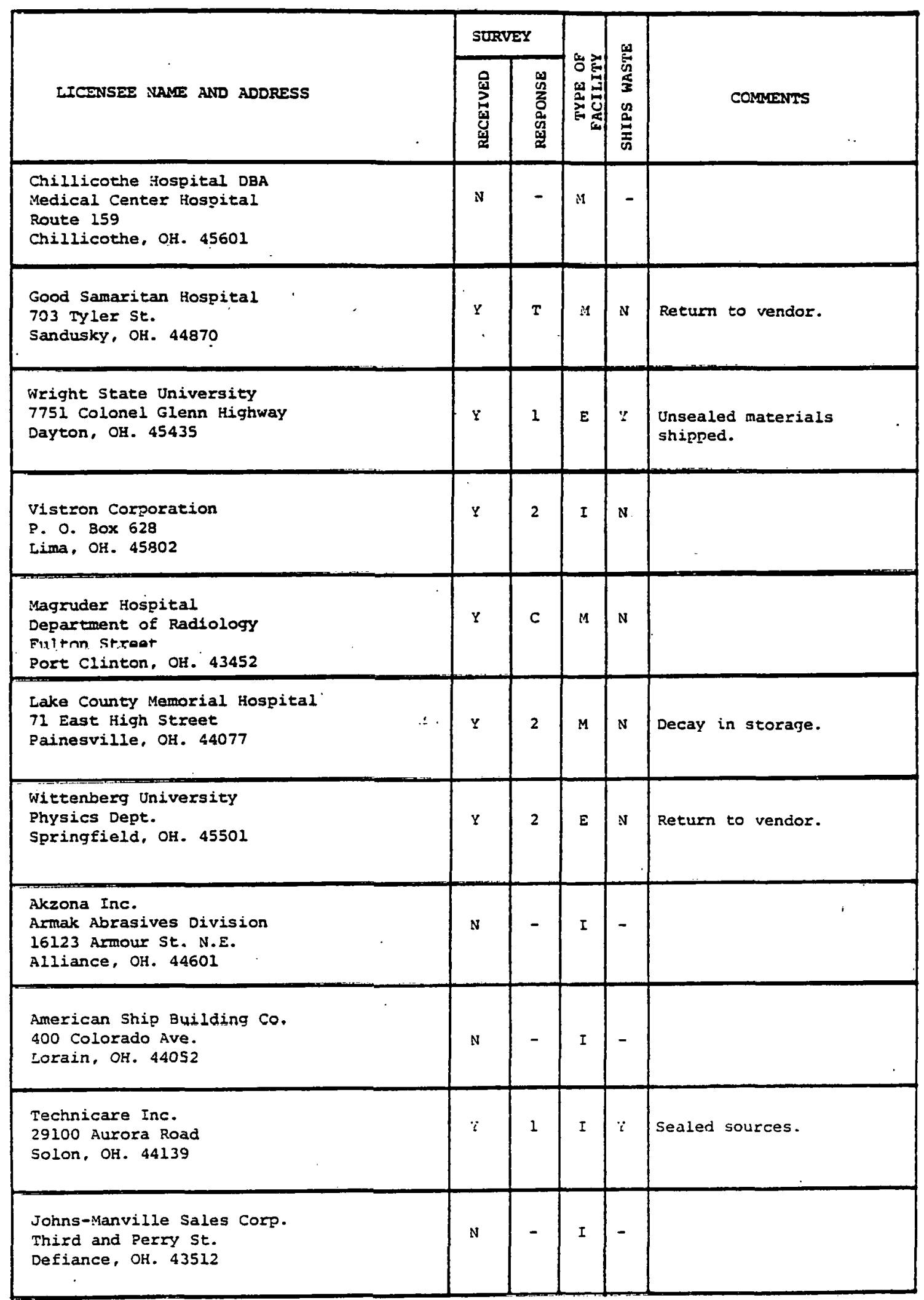




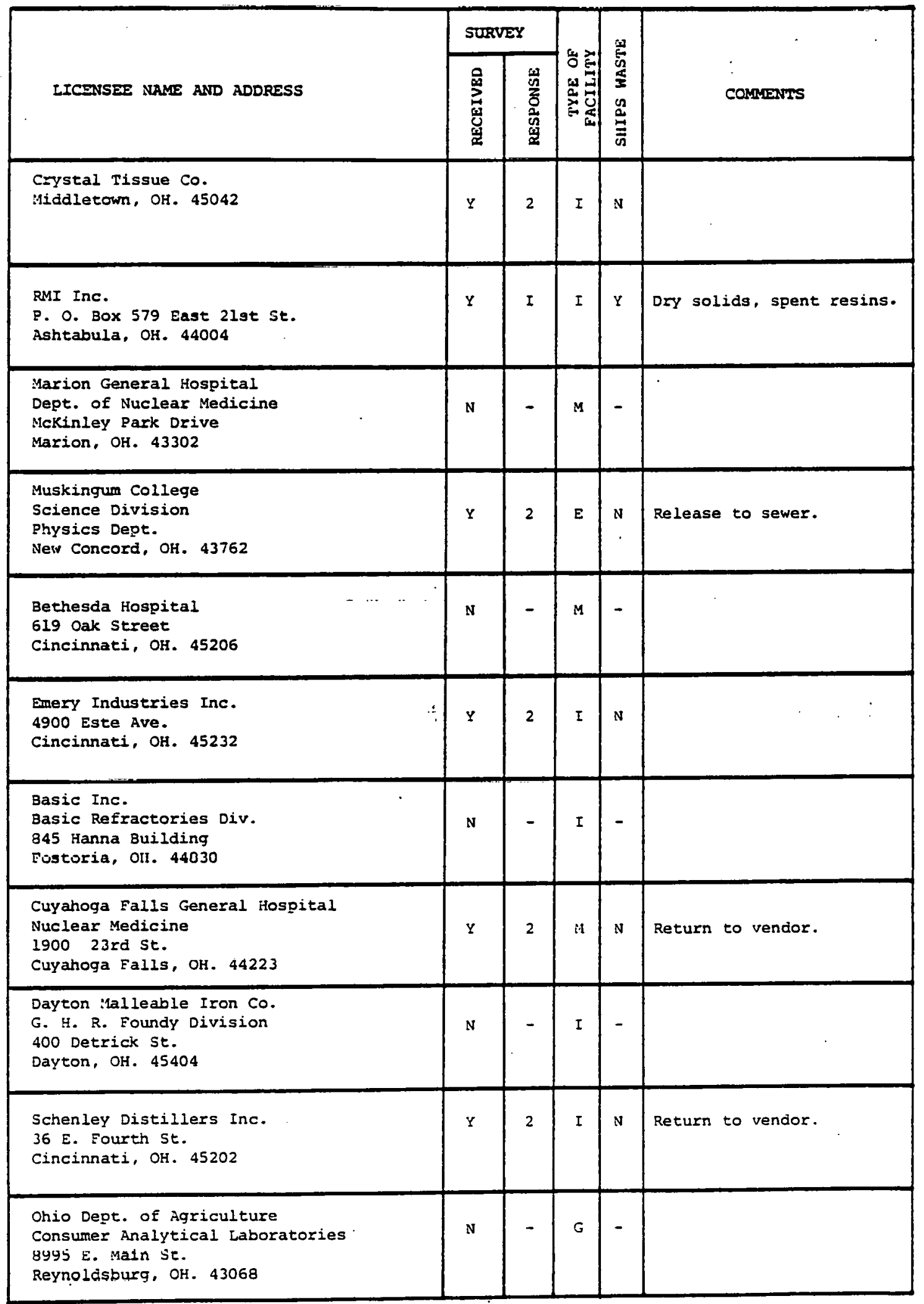




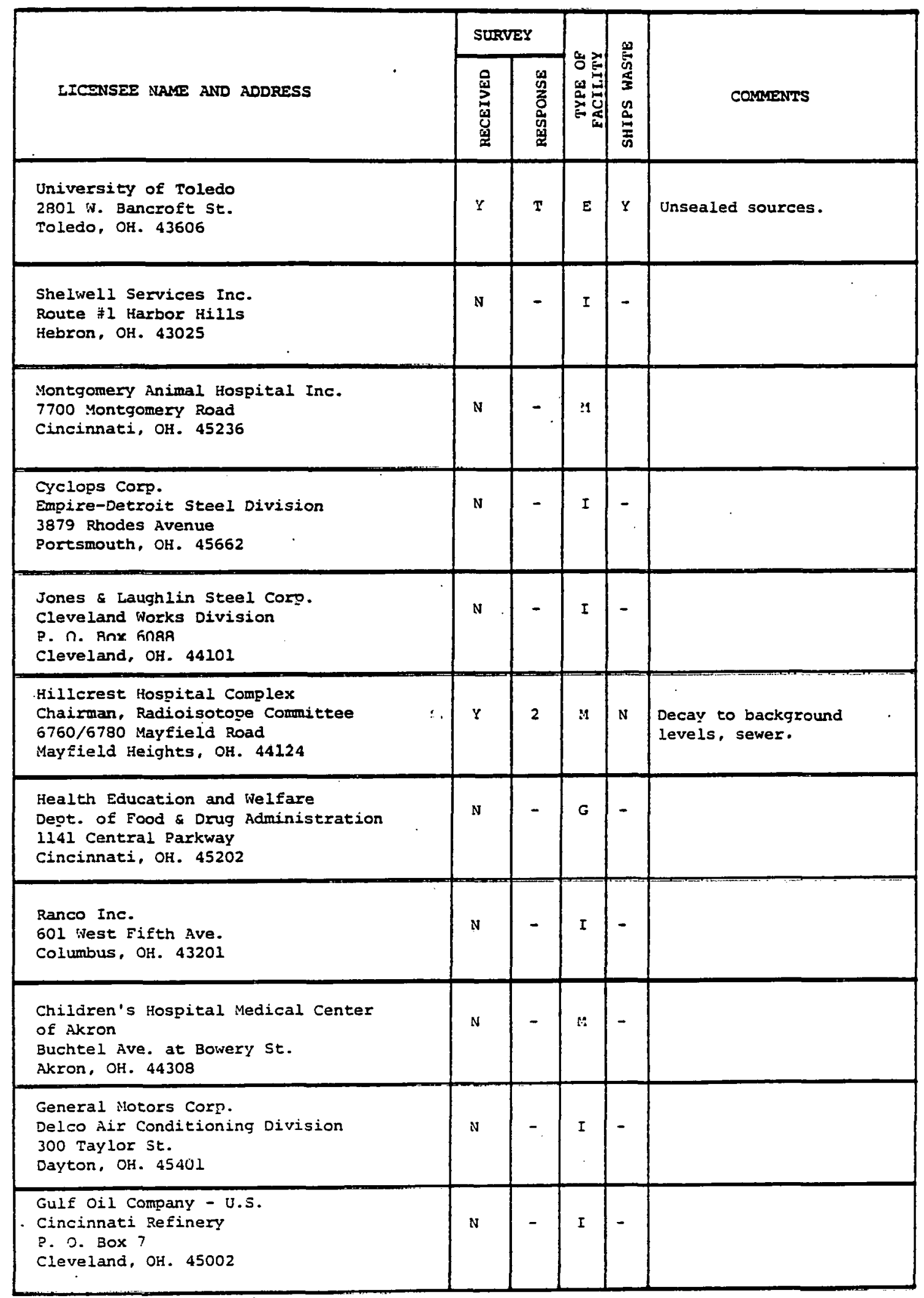




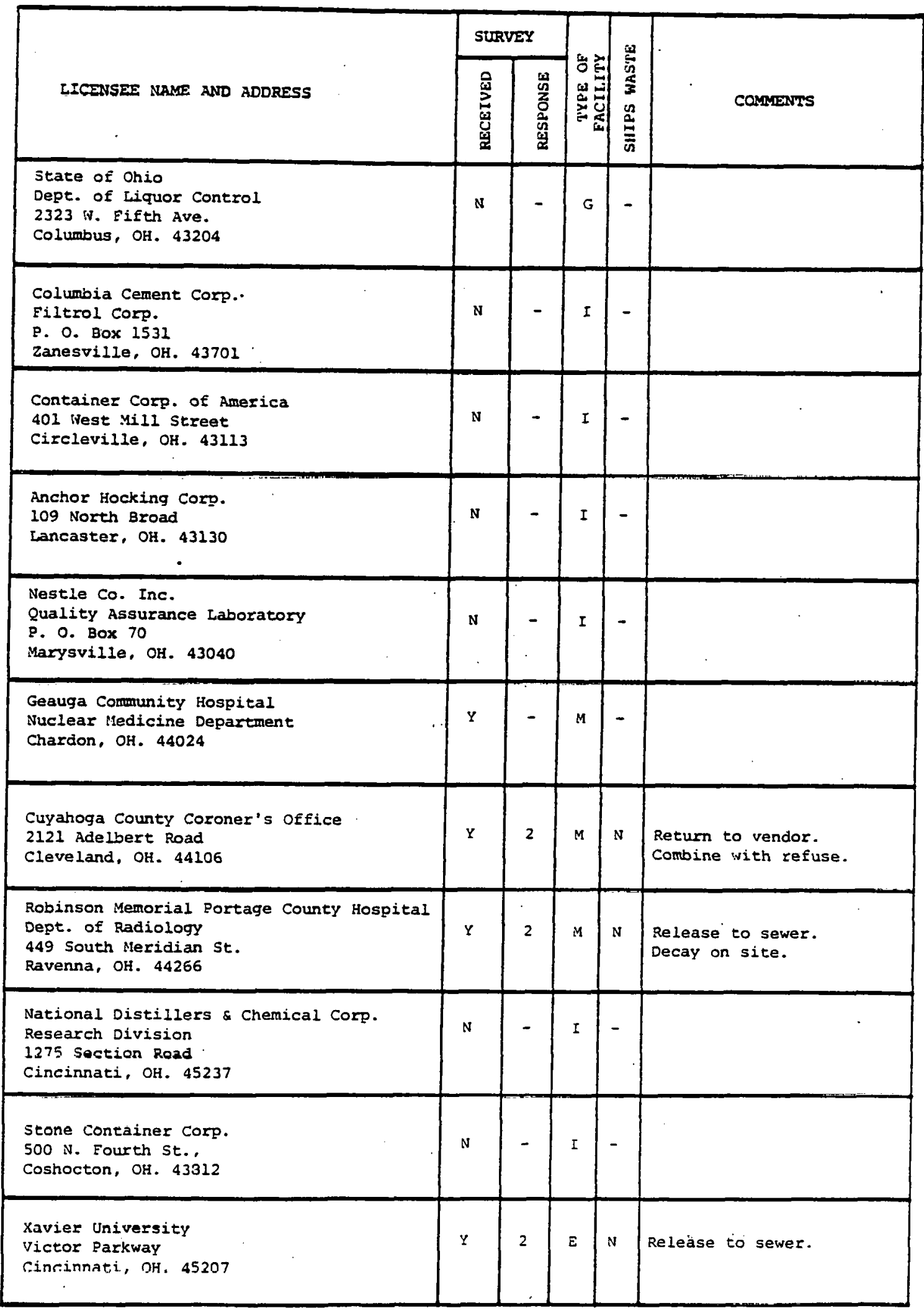




\begin{tabular}{|c|c|c|c|c|c|}
\hline \multirow[b]{2}{*}{ LICENSEE NAME AND ADDRESS } & \multicolumn{2}{|c|}{ SURVEY } & \multirow{2}{*}{ 它突 } & \multirow{2}{*}{ 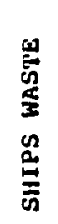 } & \multirow[b]{2}{*}{ COMLENISS } \\
\hline & $\sum_{\substack{2 \\
0}}^{0}$ & 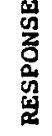 & & & \\
\hline $\begin{array}{l}\text { B. F. Goodrich Co. } \\
\text { D/3201 B/10-B } \\
\text { 500 S. Main St. } \\
\text { Akron, OH. } 44318\end{array}$ & $\mathrm{~N}$ & - & I & - & \\
\hline $\begin{array}{l}\text { DBA General Testing \& Engineering Co. } \\
\text { P. O. Box } 116 \\
\text { Washingtonville, OH. } 44490\end{array}$ & $\mathbf{N}$ & - & I & - & - \\
\hline $\begin{array}{l}\text { Shelter-Rite } \\
\text { Division of Seaman Corp. } \\
\text { Route } 1 \\
\text { Millersburg, OH: } 44654\end{array}$ & $\mathbf{N}$ & - & I & - & \\
\hline $\begin{array}{l}\text { Galion Community Hospital } \\
\text { Portland Way South } \\
\text { Galion, OH. } 44902\end{array}$ & $Y$ & 2 & M & $\mathbf{N}$ & Return to vendor. \\
\hline $\begin{array}{l}\text { Cleveland State University } \\
\text { Euclid Ave. at 24th St. } \\
\text { Cleveland, OH. } 44115\end{array}$ & $\mathbf{T}$ & 2 & $\mathbf{E}$ & $\mathbf{N}$ & Return to vendor. \\
\hline $\begin{array}{l}\text { New Jersey zinc Co. } \\
\text { Middle Road } \\
\text { Ashtabula, OH. } 44004\end{array}$ & $\mathrm{~N}$ & - & I & - & \\
\hline $\begin{array}{l}\text { Department of the Air Force } \\
\text { Aerospace Guidance \& Metrology Center } \\
\text { Newark Air Force Station } \\
\text { Newark, OH. } 43055\end{array}$ & $\mathbf{N}$ & - & G & - & \\
\hline $\begin{array}{l}\text { CTL Engineering Ine. } \\
2860 \text { Fisher Road } \\
\text { Columbus, OH. } 43204\end{array}$ & $Y$ & 2 & I & $\mathrm{N}$ & Return to vendor. \\
\hline $\begin{array}{l}\text { Marathon Pipe Line Co. } \\
539 \text { South Main St. } \\
\text { Findlay, OH. } 45840\end{array}$ & $\mathrm{~N}$ & - & I & - & : \\
\hline $\begin{array}{l}\text { B. F. Goodrich Chemical Co. } \\
\text { Technical (Development) Center } \\
\text { P. O. Box 122, Moore \& Walker Rd. } \\
\text { Avon Lake, OH. } 44012\end{array}$ & $y$ & 2 & I & $\mathbf{N}$ & Return to vendor. \\
\hline $\begin{array}{l}\text { Union Carbide Corp. } \\
\text { Battery Products Division } \\
1280 \text { west } 73 \text { rd Street } \\
\text { Cleveland, OH. } 44101\end{array}$ & $\mathbf{N}$ & - & I & - & \\
\hline
\end{tabular}




\begin{tabular}{|c|c|c|c|c|c|}
\hline \multirow[b]{2}{*}{ LICENSEE NAME AND ADDRESS } & \multicolumn{2}{|c|}{ SURVEY } & \multirow{2}{*}{ 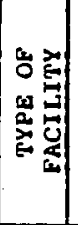 } & \multirow{2}{*}{ 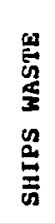 } & \multirow[b]{2}{*}{ Comagniss } \\
\hline & 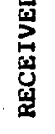 & 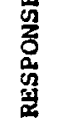 & & & \\
\hline $\begin{array}{l}\text { Bearfoot Corporation } \\
\text { Eirst \& Water Sts. } \\
\text { Nadsworth, OH. } 44281\end{array}$ & $\mathbf{N}$ & - & I & - & \\
\hline $\begin{array}{l}\text { Borden Inc. - QAL } \\
990 \text { kingsmill Parkway } \\
\text { Columbus, OH. } 43229\end{array}$ & $\mathbf{N}$ & - & I & - & \\
\hline $\begin{array}{l}\text { Brush Wellman Inc. } \\
\text { South River Road } \\
\text { Elmore, OH. } 43416\end{array}$ & $Y$ & 2 & $\mathbf{I}$ & $\mathbf{M}$ & Return to vendor. \\
\hline $\begin{array}{l}\text { Westreco Inc. } \\
809 \text { Collins Avenue } \\
\text { Marysville, OH. } 43040\end{array}$ & $\mathbf{N}$ & - & I & - & \\
\hline $\begin{array}{l}\text { Hoftman Bumingham \& Assoc. Ine. } \\
40 \text { Clay } \\
\text { Tiffin, OH. } 44883\end{array}$ & N & - & I & - & \\
\hline $\begin{array}{l}\text { Omet Corporation } \\
\text { P. O. Box } 176 \\
\text { Hannibal, OH. } 43931\end{array}$ & $N$ & - & I & - & \\
\hline $\begin{array}{l}\text { University of Dayton } \\
\text { Research Institute } \\
300 \text { College Park } \\
\text { Dayton, OH. } 45469\end{array}$ & N & - & $\mathbf{E}$ & - & \\
\hline $\begin{array}{l}\text { Parma Community General Hospital } \\
\text { Dept. of Radiology } \\
7007 \text { Powers Blvd. } \\
\text { Parma, OH. } 44129\end{array}$ & $\mathbf{Y}$ & 2 & M & $\mathbf{I}$ & Decayed in storage. \\
\hline $\begin{array}{l}\text { Union Carbide Corporation } \\
\text { Metals Division } \\
\text { P. O. Box } 299 \\
\text { Marietta, OH. } 45750\end{array}$ & $\mathbf{N}$ & - & I & - & \\
\hline $\begin{array}{l}\text { Middletown flospital Assoc. } \\
105 \text { MeKnight Drive } \\
\text { Middletown, OH. } 45042\end{array}$ & $\mathrm{~N}$ & - & $M$ & - & \\
\hline $\begin{array}{l}\text { Otterbein College } \\
\text { Nesterville, OH. } 43081\end{array}$ & $\mathbf{N}$ & - & $E$ & - & \\
\hline
\end{tabular}




\begin{tabular}{|c|c|c|c|c|c|}
\hline & SUR & & & & \\
\hline LICSNSEE NAME AND ADDRESS & 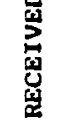 & 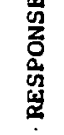 & 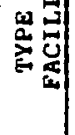 & 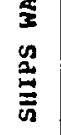 & COMMENITS \\
\hline $\begin{array}{l}\text { Dow Chemical U.S.A. } \\
3441 \text { North Main Street } \\
\text { Findlay, OH. } 45840\end{array}$ & $\mathbf{N}$ & - & I & - & \\
\hline $\begin{array}{l}\text { Cincinnati Gas \& Electric Co. } \\
\text { Electric Production } \\
\text { 4th \& Main'Sts. } \\
\text { Cincinnati, OH. } 45202\end{array}$ & $\mathbf{N}$ & - & I & - & \\
\hline $\begin{array}{l}\text { Inmont Corp. } \\
837 \text { Buckingham St. } \\
\text { Toledo, OH. } 43601\end{array}$ & $\mathbf{N}$ & - & I & - & $\cdot$ \\
\hline $\begin{array}{l}\text { Standard Oil Co. } \\
\text { Toledo Refinery } \\
\text { Cedar Point Road } \\
\text { Toledo, OH. } 43694\end{array}$ & $Y$ & - & I & $\mathrm{N}$ & Return to vendor. \\
\hline $\begin{array}{l}\text { Sandusky Memorial Hosoital } \\
\text { Nuclear Medicine } \\
2020 \text { Haynes Street } \\
\text { 3oindusky, OH. } 44870\end{array}$ & $\mathbf{N}$ & - & $M$ &. & \\
\hline $\begin{array}{l}\text { Massillon Community Hospital } \\
876 \text { Amherst Road, N.E. } \\
\text { Massillon, OH. } 44646\end{array}$ & $Y$ & $\mathbf{T}$ & $\mathbf{M}$ & $\mathrm{N}$ & $\begin{array}{l}\text { Combine with refuse. } \\
\text { vent to atmosphere. }\end{array}$ \\
\hline $\begin{array}{l}\text { Columbus Coated Fabrics } \\
\text { Division of Borden Chemical Co. } \\
1280 \text { North Grant Ave. } \\
\text { Columbus, OH. } 43216\end{array}$ & $\mathbf{N}$ & - & I & - & \\
\hline $\begin{array}{l}\text { Dayton Malleable Inc. } \\
\text { Ironton Division } \\
2520 \text { South Third Street } \\
\text { Ironton, OH. } 45638\end{array}$ & $\mathbf{N}$ & - & I & - & \\
\hline $\begin{array}{l}\text { Dayton } x-\text { Ray Company } \\
\text { Non-Destructive } x-\text { Ray Lab. } \\
\text { 1150 West 2nd Street } \\
\text { Dayton, OH. } 45407\end{array}$ & $\mathbf{N}$ & - & I & - & . \\
\hline $\begin{array}{l}\text { Johns-Manville Sales Corp. } \\
\text { ialophane Division } \\
214 \text { Oakwood Avenue } \\
\text { Newark, OH. } 43055\end{array}$ & $\mathbf{N}$ & - & I & - & . \\
\hline $\begin{array}{l}\text { Cleveland Electric Illuminating Co. } \\
\text { P. O. Box } 5000 \\
\text { Cleveland. OH. } 44101\end{array}$ & $\mathrm{~N}$ & - & I & - & \\
\hline
\end{tabular}




\begin{tabular}{|c|c|c|c|c|c|}
\hline \multirow[b]{2}{*}{ LICSNSEE NAME AND ADDRESS } & \multicolumn{2}{|c|}{ SURVEY } & \multirow{2}{*}{ 要齐 } & \multirow{2}{*}{ 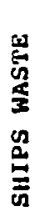 } & \multirow[b]{2}{*}{ COMMENTS } \\
\hline & 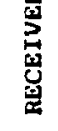 & $\begin{array}{l}\text { ñ } \\
\text { Oे } \\
\text { 品 } \\
0 \\
0\end{array}$ & & & \\
\hline $\begin{array}{l}\text { Monsanto Research Corp. } \\
\text { Dayton Laboratory } \\
1515 \mathrm{Nicholas} \mathrm{Road} \\
\text { Dayton, OH. } 45407\end{array}$ & $Y$ & $\mathbf{T}$ & I & $Y$ & Transuranic material sent. \\
\hline $\begin{array}{l}\text { Dept. of Health Education and Welfare } \\
\text { National Institute of Occupational Safety } \\
\text { \& Health, R. A. Taft Labs } \\
4767 \text { Columbia Parkway } \\
\text { Cincinnati, OH. } 45226\end{array}$ & $\mathbf{N}$ & - & G & - & · \\
\hline $\begin{array}{l}\text { John Carroll University } \\
\text { Biology Dept. } \\
\text { North Park \& Miramar Blvd. } \\
\text { Cleveland, OH. } 44118\end{array}$ & $Y$ & 2 & $\begin{array}{c}\varepsilon \\
\text {. }\end{array}$ & N & $\begin{array}{l}\text { Release to sewer. } \\
\text { Decay to background. }\end{array}$ \\
\hline $\begin{array}{l}\text { Pieker Corporation } \\
\text { Picker X-Ray Mfg. Div. } \\
595 \text { Miner Road } \\
\text { Cleveland, OH. } 44143\end{array}$ & $\mathbf{N}$ & - & I & - & . \\
\hline $\begin{array}{l}\text { Pharmatopes Inc. } \\
2208 \text { West Central Avenue } \\
\text { Toledo. OH. } 43606\end{array}$ & $Y$ & 2 & I & $\mathbf{N}$ & Unsealed materials. \\
\hline $\begin{array}{l}\text { Warren Outpatient Services Inc. } \\
4687 \text { Mahoning, N.W. } \\
\text { Warren, OH. } 44483\end{array}$ & $Y$ & 2 & M & $\mathbf{N}$ & Combine with refuse. \\
\hline $\begin{array}{l}\text { Bethesda Hospital } \\
\text { North Maple Street } \\
\text { Zanesville, OH. } 43701\end{array}$ & $\mathbf{N}$ & - & $M$ & - & \\
\hline $\begin{array}{l}\text { Good Samaritan Hospital } \\
\text { soo Forest Avenue } \\
\text { Zanesville, OH. } 43701\end{array}$ & $\mathbf{N}$ & - & $M$ & - & \\
\hline $\begin{array}{l}\text { Coshocton County Memorial Hospital } \\
1460 \text { ornage Street } \\
\text { Coshocton, OH. } 43812\end{array}$ & $\mathrm{~N}$ & - & $\because 1$ & - & \\
\hline $\begin{array}{l}\text { Eco-Labs Inc. } \\
1836 \text { Euclid Avenue } \\
\text { Cleveland, OH. } 44115\end{array}$ & $\mathrm{~N}$ & - & I & - & . \\
\hline $\begin{array}{l}\text { Northeastern Ohio General Hospital } \\
2041 \text { Hubbard Road } \\
\text { North Madicon, OH. } 44057\end{array}$ & $\mathbf{N}$ & - & $\mathbf{M}$ & - & \\
\hline
\end{tabular}




\begin{tabular}{|c|c|c|c|c|c|}
\hline & SUR & & & & \\
\hline LICSNSEE NAME RND ADDRESS & 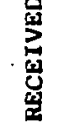 & 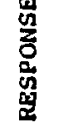 & 象矛题 & 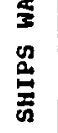 & COMMENTS \\
\hline $\begin{array}{l}\text { Tedia Company Inc. } \\
96 \text { Ardnt Court } \\
\text { Fairfield, OH. } 45014\end{array}$ & $\mathbf{N}$ & - & I & - & \\
\hline $\begin{array}{l}\text { Southern Ohio Coal Co. } \\
\text { P. O. BOx } 490 \\
\text { Athens, OH. } 45701\end{array}$ & $\mathbf{N}$ & - & I & - & \\
\hline $\begin{array}{l}\text { Pori Inc. } \\
3341 \text { Jennings Road } \\
\text { Cleveland, OH. } 44109\end{array}$ & $\mathrm{~N}$ & - & $I$ & - & \\
\hline $\begin{array}{l}\text { Mercy Memorial Hospital of Urbana Ohio } \\
904 \text { Scioto Street } \\
\text { Urbana, OH. } 43078\end{array}$ & $\mathbf{Y}$ & 2 & $\mathrm{M}$ & $\mathbf{N}$ & $\begin{array}{c}\text { Return to vendor. } \\
\text { - }\end{array}$ \\
\hline $\begin{array}{l}\text { Grace Hospital } \\
2307 \text { West 14th Street } \\
\text { Cleveland, OH. } 44113\end{array}$ & $\mathbf{N}$ & - & $M$ & - & \\
\hline $\begin{array}{l}\text { Massilion, City of } \\
\text { Wastewater Treatment Plant } \\
2695 \text { Erie Avenue Aouth } \\
\text { Massillon, OH. } 44646\end{array}$ & $\mathrm{~N}$ & - & G & - & $\theta$ \\
\hline $\begin{array}{l}\text { Guernsey Memorial Hospital } \\
\text { Nuclear Medicine } \\
\text { l34I N. Clark Street } \\
\text { Cambridge, OH. } 43725\end{array}$ & $\mathbf{N}$ & - & $\therefore$ & - & \\
\hline $\begin{array}{l}\text { Associates in Radiology Inc. } \\
1027 \text { Boardman-Canfield Road } \\
\text { Youngstown, OH. } 44512\end{array}$ & $\mathrm{~N}$ & - & $M$ & - & \\
\hline $\begin{array}{l}\text { Sherwin Nilliams Chemicals } \\
\text { S01 Murray Road } \\
\text { Cincinnati, OH. } 45217\end{array}$ & $\mathbf{Y}$ & 2 & I & $\mathbf{N}$ & Return to vendor. \\
\hline $\begin{array}{l}\text { CLC Labs } \\
\text { Busch Corporate Center } \\
1046 \text { Crupper Ave. } \\
\text { Columbus, OH. } 43229\end{array}$ & $Y$ & 2 & I & $\mathrm{N}$ & Sealed sources. \\
\hline $\begin{array}{l}\text { Clow Corporation } \\
\text { P. O. Box } 479 \\
\text { Coshocton, OH. } 43812\end{array}$ & $\mathbf{Y}$ & 2 & I & $\mathrm{N}$ & Sealed sources. \\
\hline
\end{tabular}




\begin{tabular}{|c|c|c|c|c|c|}
\hline \multirow[b]{2}{*}{ LICENSEE NAME AND ADDRESS } & \multicolumn{2}{|c|}{ SURVEY } & \multirow{2}{*}{ 岁吝 } & \multirow{2}{*}{ 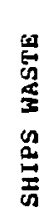 } & \multirow[b]{2}{*}{ COMAENTS } \\
\hline & 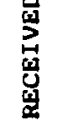 & 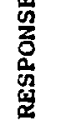 & & & \\
\hline $\begin{array}{l}\text { State of Ohio arson Laboratory } \\
333 \\
\text { Columbus, OH. } 43215\end{array}$ & $\mathbf{N}$ & - & G & - & \\
\hline $\begin{array}{l}\text { Nuclear Pharmacies International Inc. } \\
\text { 10900 Carnegie Ave. } \\
\text { Suite } 308 \\
\text { Cleveland, OH. } 44106\end{array}$ & $\mathbf{N}$ & - & I & - & \\
\hline $\begin{array}{l}\text { Medina Community Hospital } \\
\text { Nuclear Medicine Department } \\
990 \text { E. Washington } \\
\text { Medina, OH. } 44256\end{array}$ & $\mathbf{N}$ & - & M & - & \\
\hline $\begin{array}{l}\text { RCA Corporation } \\
\text { Route 12, Fostoria Road } \\
\text { Findlay. OH. } 45840\end{array}$ & $\mathbf{Y}$ & 2 & I & $\mathbf{N}$ & Sealed sources. \\
\hline $\begin{array}{l}\text { Horizons Research Inc. } \\
\text { Photohorizons Division } \\
23800 \text { Mercantile Road } \\
\text { Cleveland, OH. } 44122\end{array}$ & $\mathrm{~N}$ & - & I & - & \\
\hline $\begin{array}{l}\text { Medical Diagnostic Services Inc. } \\
\text { Division of Chemed Corp. } \\
4531 \text { Reading Road } \\
\text { Cincinnati, OH. } 45229\end{array}$ & $\mathbf{N}$ & $\overrightarrow{-}$ & I & - & \\
\hline $\begin{array}{l}\text { Owens-Coming Fiberglas Corp. } \\
\text { Environmental Control Lab } \\
\text { Case Avenue, } \\
\text { Newark, OH. } 43055\end{array}$ & $\mathbf{N}$ & - & $I$ & - & \\
\hline $\begin{array}{l}\text { Montgomery County Coroner's office } \\
\text { I20 Ziegler Street } \\
\text { Dayton, OH. } 45402\end{array}$ & $Y$ & 2 & $M$ & $\mathbf{N}$ & $\begin{array}{l}\text { Sealed/unsealed sources. } \\
\text { Release to sewer. }\end{array}$ \\
\hline $\begin{array}{l}\text { University Suburban Health Center } \\
\text { Dept. of Clinical Pathology } \\
\text { l6il South Green Road } \\
\text { South Euclid, OH. } 44121\end{array}$ & N & - & -1 & - & \\
\hline $\begin{array}{l}\text { Lawrence County General Hosnital } \\
\text { Radioisotope Service } \\
\text { Jospital Square } 2228 \text { s. 9th St. } \\
\text { Ironton, OH. } 45638\end{array}$ & $\mathrm{~N}$ & - & M & - & \\
\hline $\begin{array}{l}\text { Cuyahoga County Engineer } \\
1926 \text { Northern Ohio Bank Bldg. } \\
\text { Cleveland, OH. } 44113\end{array}$ & $\mathbf{Y}$ & 2 & G & $\mathrm{N}$ & Return to vendor. \\
\hline
\end{tabular}




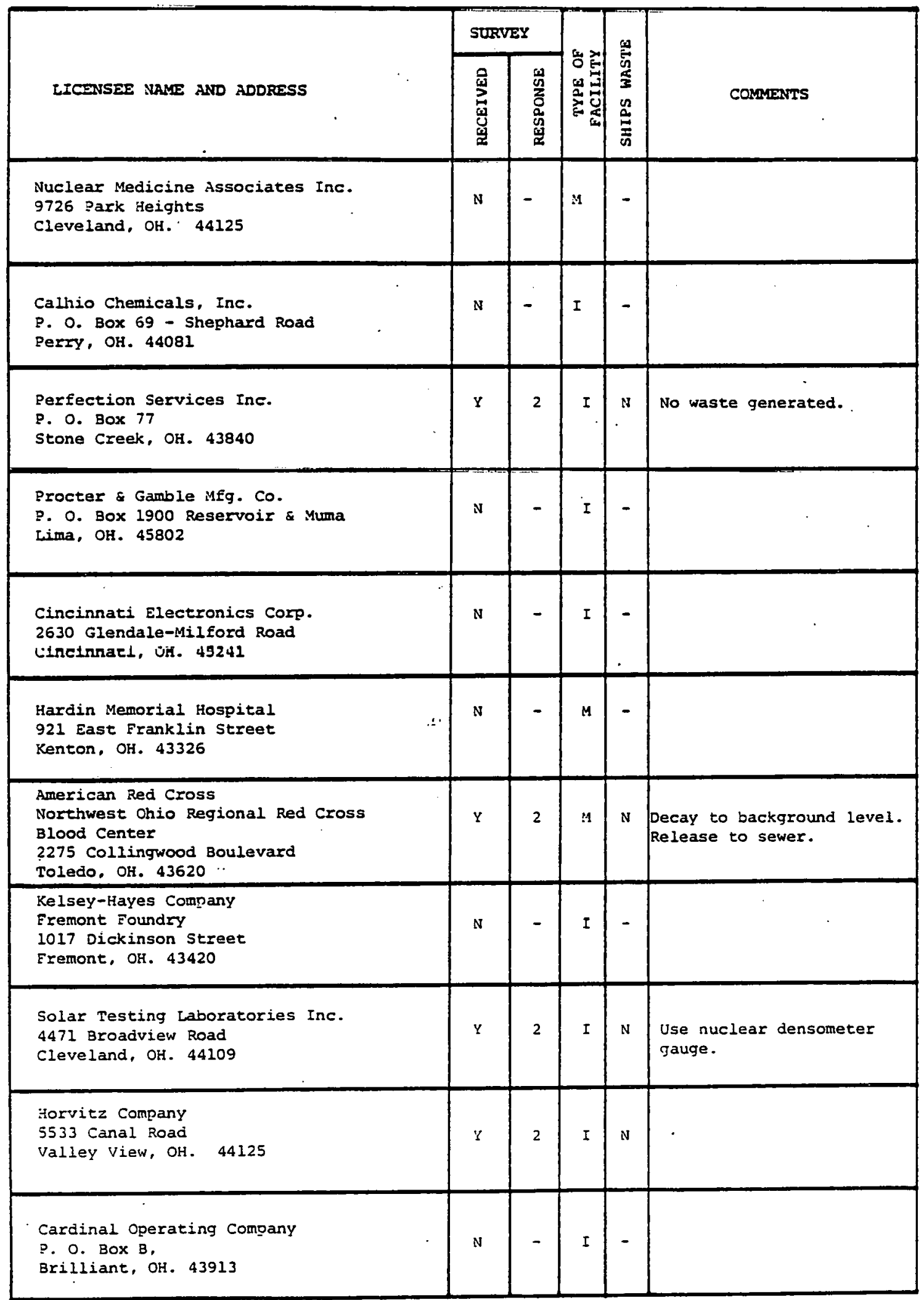




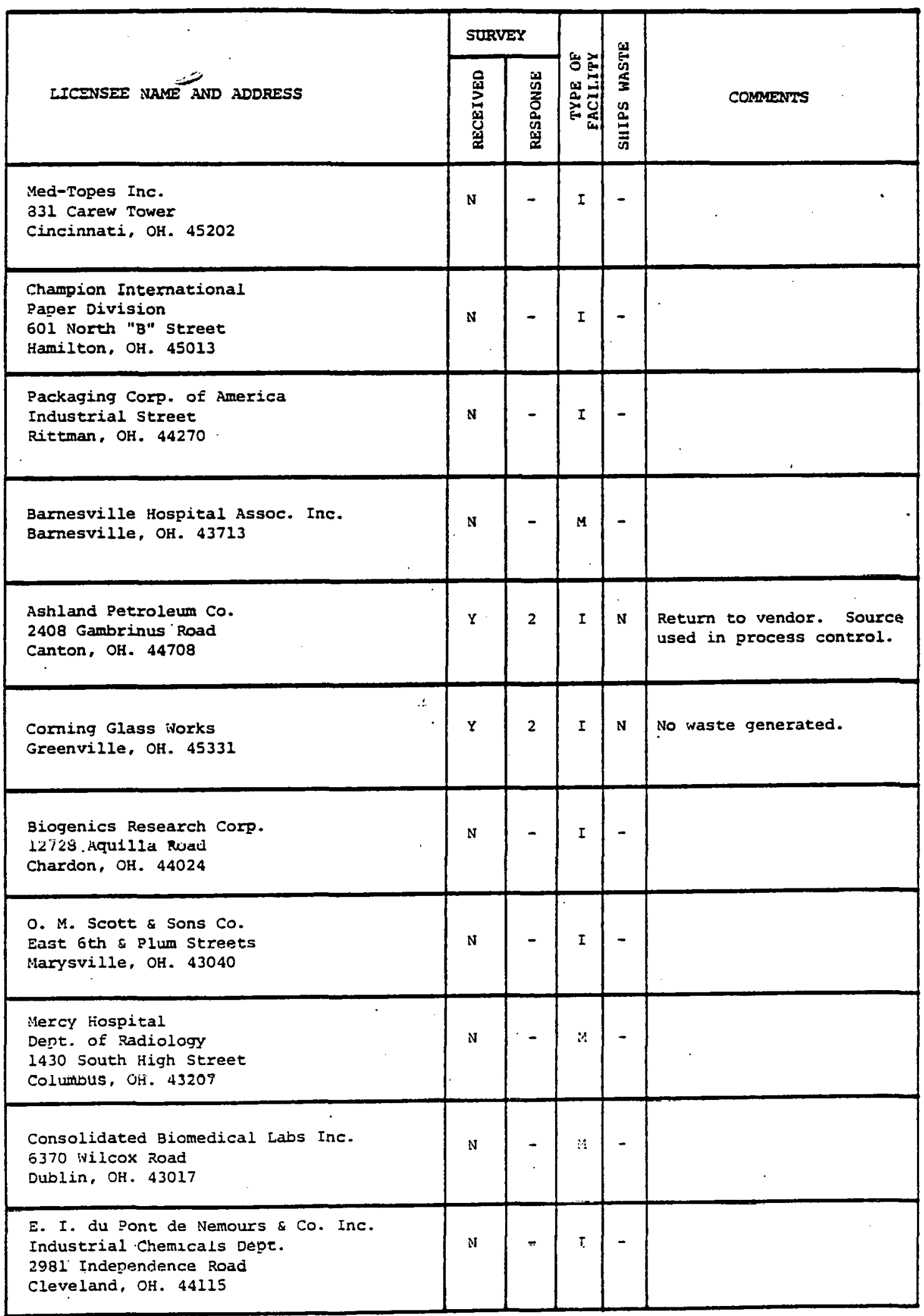




\begin{tabular}{|c|c|c|c|c|c|}
\hline \multirow[b]{2}{*}{ LICENSEE NAME AND ADDRESS } & \multicolumn{2}{|c|}{ SURVEY } & \multirow{2}{*}{ 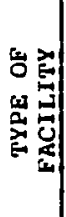 } & \multirow{2}{*}{ 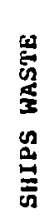 } & \multirow[b]{2}{*}{ COMMENTS } \\
\hline & $\sum_{\substack{1 \\
0}}^{0}$ & 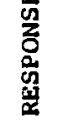 & & & \\
\hline $\begin{array}{l}\text { Marietta College } \\
\text { Biology Dept. } \\
215 \text { 5th St. } \\
\text { Marietta. OH. } 45750\end{array}$ & $\mathbf{Y}$ & 1 & $\mathbf{E}$ & $\mathbf{Y}$ & $\begin{array}{l}\text { Unsealed source. Waste } \\
\text { shipped to Ohio University } \\
\text { where combined with their } \\
\text { waste. }\end{array}$ \\
\hline $\begin{array}{l}\text { Koehring } \\
\text { Road Division } \\
1210 \text { Renton St., P. O. Box } 95 \\
\text { Springfield, OH. } 45501\end{array}$ & N & - & I & - & . \\
\hline $\begin{array}{l}\text { Walworth Co. } \\
\text { Columbus Plant } \\
\text { 6Il Marion Road } \\
\text { Columbus, OH. } 43207\end{array}$ & N & - & I & - & . \\
\hline $\begin{array}{l}\text { Scioto Memorial Hospita! } \\
180527 \text { th St. } \\
\text { Portsmouth, OH. } 45662\end{array}$ & N & - & M & - & \\
\hline $\begin{array}{l}\text { Diamond Shamrock Corp. } \\
1100 \text { Superior Ave. } \\
\text { Cleveland. } \mathrm{OH} \text {. } 4 \Delta, 114\end{array}$ & N & - & I & - & \\
\hline $\begin{array}{l}\text { Bayless Pathology Associates Inc. } \\
\text { Severance Medical Arts Building } \\
5 \text { Severance Cfrcle, Suite } \# 804 \\
\text { Cleveland Heights, OH. } 44118\end{array}$ & N & - & M & - & \\
\hline $\begin{array}{l}\text { Wooster Community Hospital } \\
1761 \text { Beall Avenue } \\
\text { Wooster, OH. } 44691\end{array}$ & $\underline{v}$ & 2 & $M$ & $N$ & $\begin{array}{l}\text { Release to sewer. } \\
\text { Combine with refuse. }\end{array}$ \\
\hline $\begin{array}{l}\text { Cincinnati Milacron Chemicals Inc. } \\
\text { Production Department } \\
\text { West Street } \\
\text { Reading, OH. } 45213\end{array}$ & N & - & I & - & \\
\hline $\begin{array}{l}\text { Bryan Community Hospital Inc. } \\
\text { W. High Street } \\
\text { Bryan, OH. } 43506\end{array}$ & $Y$ & 2 & :1 & $\mathrm{N}$ & Return to vendor. \\
\hline $\begin{array}{l}\text { Neurological Diagnostic Clinic } \\
932 \text { Belmont Avenue } \\
\text { Youngstown, OH. } 44504\end{array}$ & N & - & $\because 4$ & - & \\
\hline $\begin{array}{l}\text { Defiance Hospital } \\
1206 \text { E. Second Street } \\
\text { Defiance, OH. } 43512 \\
\end{array}$ & N & - & M & - & \\
\hline
\end{tabular}




\begin{tabular}{|c|c|c|c|c|c|}
\hline \multirow[b]{2}{*}{ LICDNSEE NAME AND ADDRESS } & \multicolumn{2}{|c|}{ SURVEY } & \multirow{2}{*}{ 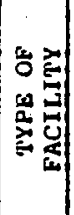 } & \multirow{2}{*}{ 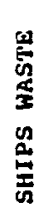 } & \multirow[b]{2}{*}{ COMNENTS } \\
\hline & 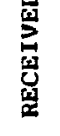 & 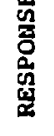 & & & \\
\hline $\begin{array}{l}\text { East Liverpool City Hospital } \\
425 \text { Nest Eifth Street } \\
\text { East Liverpool, OH. } 43920\end{array}$ & y & 2 & $\mathrm{M}$ & $\mathrm{N}$ & $\begin{array}{l}\text { Combine with common } \\
\text { refuse. }\end{array}$ \\
\hline $\begin{array}{l}\text { Union Carbide Corporation } \\
\text { Metals Division } \\
\text { Lake Road East } \\
\text { Ashtabula, OH. } 44004\end{array}$ & $\boldsymbol{r}$ & 2 & $I$ & $\mathbf{N}$ & Sealed source used. \\
\hline $\begin{array}{l}\text { Union Hospital Association } \\
659 \text { Boulevard } \\
\text { Dover, OH. } 44622\end{array}$ & $Y$ & 2 & $\mathbf{M}$ & $\mathbf{N}$ & $\begin{array}{l}\text { Combine with refuse. } \\
\text { Return to vendor. }\end{array}$ \\
\hline $\begin{array}{l}\text { Community Hospital of Springfield } \\
2615 \text { East High Street } \\
\text { Springfield, OH. } 45501\end{array}$ & $Y$ & 2 & M & $\mathbf{N}$ & $\begin{array}{l}\text { Vent, release to sewer. } \\
\text { Return to vendor. }\end{array}$ \\
\hline $\begin{array}{l}\text { American Red Cross } \\
\text { Northern Ohio Red Cross Blood Center } \\
3950 \text { Chester Avenue } \\
\text { Cleveland, OH. } 44114\end{array}$ & $\mathbf{Y}$ & 2 & $M$ & $N$ & $\begin{array}{l}\text { Release to sewer. } \\
\text { Combine with refuse. }\end{array}$ \\
\hline $\begin{array}{l}\text { American Red Cross } \\
\text { Central Ohio Red Cross Blood Center } \\
995 \text { E. Broad Street } \\
\text { Columbus, OH. } 43205\end{array}$ & $Y$ & 2 & M & $N$ & Combine with refuse. \\
\hline $\begin{array}{l}\text { Bucyrus Community Hospital } \\
629 \text { N. Sandusky Avenue } \\
\text { Bucyrus, OH. } 44320\end{array}$ & $Y$ & 2 & M & $\mathbf{N}$ & $\begin{array}{l}\text { Return to vendor. } \\
\text { Combine with refuse. }\end{array}$ \\
\hline $\begin{array}{l}\text { Therm-0-Dise Inc. } \\
\text { Subsidiary of Emerson Electric Co. } \\
1320 \text { South Main Street } \\
\text { Mansfield, OH. } 44907\end{array}$ & $N$ & - & I & - & \\
\hline $\begin{array}{l}\text { Nood County Hosoital } \\
\text { Radiology Devartment } \\
950 \text { W. Nooster street } \\
\text { Bowling Green, OH. } 43402\end{array}$ & $\mathbf{N}$ & - & $\because$ & - & \\
\hline $\begin{array}{l}\text { Lake County Memorial Hospital } \\
\text { c/o Dept. of Radiology } \\
36000 \text { Euclid Avenue } \\
\text { Willoughby, OH. } 44094\end{array}$ & $Y$ & - & $\because 1$ & - & Decay in storage. \\
\hline $\begin{array}{l}\text { General Motors Corporation } \\
\text { Central Eoundry Div. Defiance Plant } \\
\text { State Highway No. } 281 \\
\text { Deriance, OH. } 43512\end{array}$ & $\mathbf{N}$ & - & I & - & \\
\hline
\end{tabular}




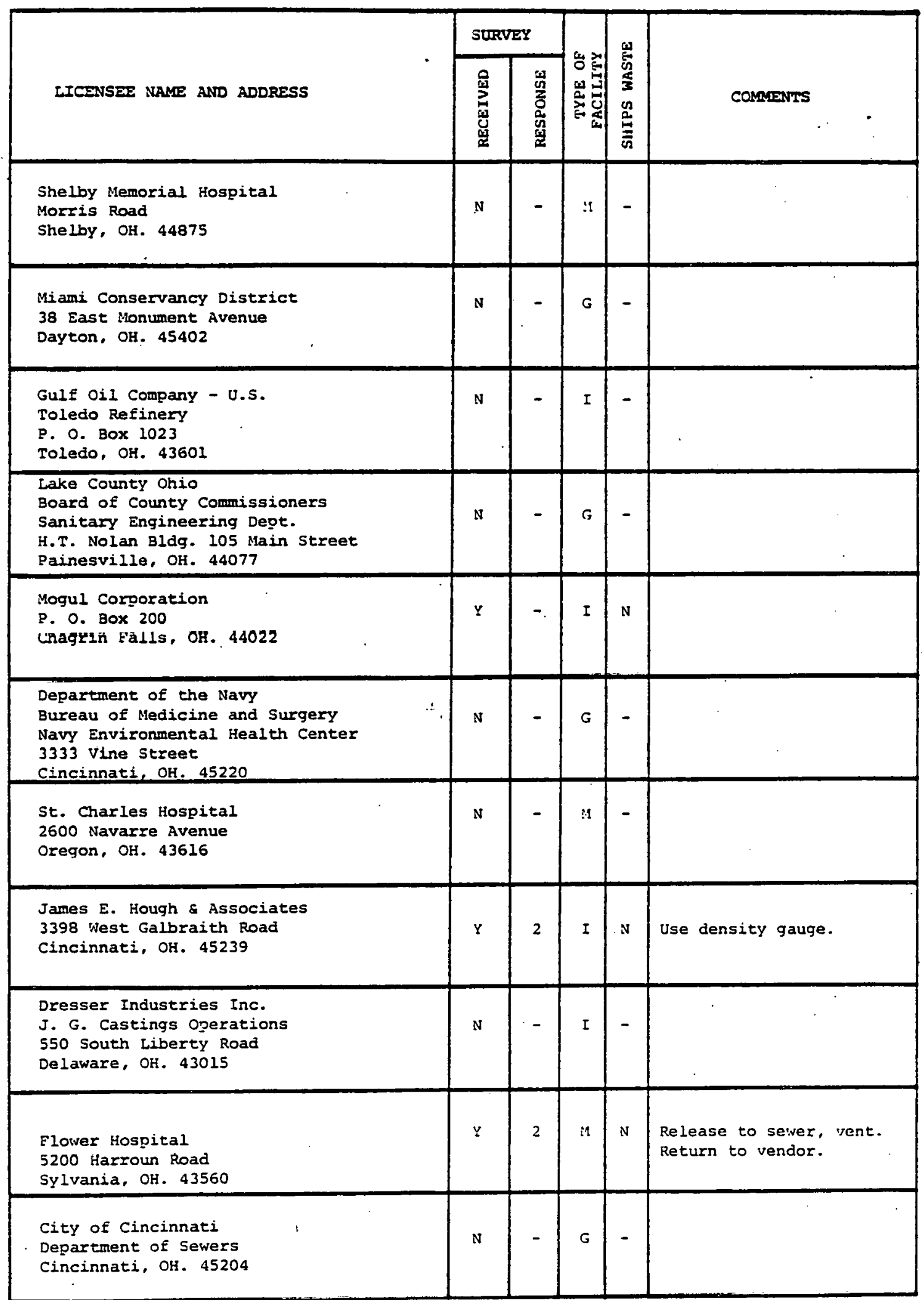




\begin{tabular}{|c|c|c|c|c|c|}
\hline & SURV & & & 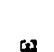 & \\
\hline LICGNSEE NAME AND ADDRESS & 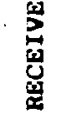 & 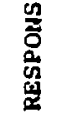 & 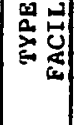 & 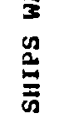 & COMMENIrs \\
\hline $\begin{array}{l}\text { Timken Company, Iac. } \\
1835 \text { Dueber Ave.., S.W. } \\
\text { Canton, OH. } 44706\end{array}$ & $Y$ & 2 & I & $\mathbf{N}$ & \\
\hline $\begin{array}{l}\text { Nuclear Consulting Services Inc. } \\
\text { Research and Field Testing } \\
\text { P. O. Box } 29151 \\
\text { Columbus, OH. } 43229\end{array}$ & $\mathbf{Y}$ & 2 & I & N & $\begin{array}{l}\text { Decay to background } \\
\text { levels, vent. }\end{array}$ \\
\hline $\begin{array}{l}\text { Defense Supply agency } \\
\text { Defense Construction Supply Center } \\
3990 \text { E. Broad St. } \\
\text { Columbus, OH. } 43215\end{array}$ & $\mathbf{N}$ & - & $G$ & - & . \\
\hline $\begin{array}{l}\text { Youngstown State University } \\
410 \text { Wick Avenue } \\
\text { Youngstown, OH. } 44503\end{array}$ & $\mathbf{Y}$ & $\mathbf{T}$ & $\mathbf{E}$ & N & $\begin{array}{l}\text { Sealed, unsealed sources } \\
\text { used. }\end{array}$ \\
\hline $\begin{array}{l}\text { Imperial Glass Corporation } \\
\text { 29th \& Belmont Sts., } \\
\text { Bellaire, OH. } 43906\end{array}$ & $\mathbf{N}$ & - & I & - & $\cdots$ \\
\hline $\begin{array}{l}\text { City of Elyria } \\
\text { Department of Health } \\
202 \text { Chestnut Street } \\
\text { Elyria, OH. } 44035\end{array}$ & $\mathbf{N}$ & - & G & - & \\
\hline $\begin{array}{l}\text { Rhone Poulenc Inc. } \\
\text { Hess \& Clark Division } \\
\text { 7th \& Orange Sts. } \\
\text { Ashland, OH. } 44805\end{array}$ & N & - & $I$ & - & . \\
\hline $\begin{array}{l}\text { H. C. Nutting Co. } \\
4120 \text { Airport Road } \\
\text { Cincinnati, OH. } 45226\end{array}$ & $\Psi$ & 2 & I & $\mathrm{N}$ & Return to vendor. \\
\hline $\begin{array}{l}\text { Dianond International Corp. } \\
407 \text { Charles Street } \\
\text { Niddiletown, PA. } 45042\end{array}$ & $\mathrm{~N}$ & - & I & - & \\
\hline $\begin{array}{l}\text { Our Lady of Mercy Hospital } \\
\text { Rowan Hills Drive } \\
\text { Mariemount } \\
\text { Cincinnati, OH. } 45227\end{array}$ & $Y$ & 1 & 4 & $Y$ & $\begin{array}{l}\text { Ship to repository. } \\
\text { Return to vendor. }\end{array}$ \\
\hline $\begin{array}{l}\text { American Aggregates Corp. } \\
\text { Garst \& Avenue B } \\
\text { Greenville. OH. } 45331\end{array}$ & $\mathrm{~N}$ & - & I & - & . \\
\hline
\end{tabular}




\begin{tabular}{|c|c|c|c|c|c|}
\hline & sur & & & & \\
\hline IICENSEE NAME AND ADDRESS & 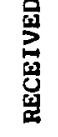 & 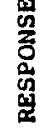 & 我式 & 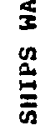 & COMmEnTS \\
\hline $\begin{array}{l}\text { Owens-Illinois Inc. } \\
\text { Technical Center } \\
711 \text { Southwood Avenue Station G } \\
\text { Columbus, OH. } 43207\end{array}$ & $\mathbf{N}$ & - & I & - & \\
\hline $\begin{array}{l}\text { Kenyon College } \\
\text { Department of Biology } \\
\text { Gambier, OH. } 43022\end{array}$ & $\mathbf{N}$ & - & $I$ & - & \\
\hline $\begin{array}{l}\text { Wauseon Eoundry Company } \\
\text { w. Leggett Street } \\
\text { Wauseon, OH. } 43567\end{array}$ & $\mathbf{N}$ & - & I & - & \\
\hline $\begin{array}{l}\text { Bellevue Hospital } \\
811 \text { Northwest Street } \\
\text { Bellevue, OH. } 44911\end{array}$ & $Y$ & 2 & $\mathbf{M}$ & $\mathrm{N}$ & $\begin{array}{l}\text { Combine with refuse. } \\
\text { Return to vendor. }\end{array}$ \\
\hline $\begin{array}{l}\text { Alliance City Hospital } \\
207 \text { E. College Street } \\
\text { Allianco, Oll. } 44601\end{array}$ & $Y$ & 2 & $M$ & $\mathrm{~N}$ & $\begin{array}{l}\text { Decay to background } \\
\text { jevels. }\end{array}$ \\
\hline $\begin{array}{l}\text { Ashland Oil Inc. } \\
5200 \text { Paul E. Blazer Memorial Py. } \\
\text { Dublin, OH. } 43017\end{array}$ & $\mathbb{N}$ & - & $I$ & - & \\
\hline $\begin{array}{l}\text { Ohio Dept. of Natural Resources } \\
\text { Division of Geological Survey } \\
\text { Eountain Square Dr. Bldg. B } \\
\text { Columbus, OH. } 43224 \text {. }\end{array}$ & $\mathbf{N}$ & - & G & - & \\
\hline $\begin{array}{l}\text { Woodville Lime \& Chemical Co. } \\
543 \text { Iime Road } \\
\text { Woodville, OH. } 43469\end{array}$ & $Y$ & 2 & I & $\mathrm{N}$ & \\
\hline $\begin{array}{l}\text { Malone Electronic Service Co. } \\
949 \text { Havensport Drive } \\
\text { Cincinnati, OH. } 45240\end{array}$ & N & - & I & - & . \\
\hline $\begin{array}{l}\text { City of Lorain } \\
\text { Water Pollution Control Dept. } \\
\text { Alaiama and Lakeside Aves. } \\
\text { Lorain, OH. } 44052\end{array}$ & $Y$ & 2 & G & $\mathrm{N}$ & \\
\hline $\begin{array}{l}\text { Providence Hospital } \\
\text { Dept. of Nuclear Medicine } \\
2446 \text { Kipling Avenue } \\
\text { Cincinnati, OH. } 45239\end{array}$ & $\mathbf{N}$ & - & M & - & \\
\hline
\end{tabular}




\begin{tabular}{|c|c|c|c|c|c|}
\hline & sur & & & & \\
\hline LICINSEE NAME AND ADDRESS & 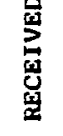 & 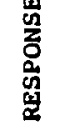 & 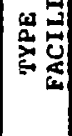 & $\begin{array}{l}\frac{\Phi}{3} \\
2 \\
\stackrel{2}{E}\end{array}$ & COMMENTS \\
\hline $\begin{array}{l}\text { MCB Manufacturing Chemists Inc. } \\
2909 \text { Highland Avenue } \\
\text { Cincinnati. OH. } 45212\end{array}$ & $\mathbf{N}$ & - & $I$ & - & - \\
\hline $\begin{array}{l}\text { Northern Columbiana County Community } \\
\text { Hospital. East Unit } \\
1995 \text { East State Street } \\
\text { Salem, OH. } 44460\end{array}$ & $\mathbf{N}$ & - & M & - & \\
\hline $\begin{array}{l}\text { Industrial Inspection Industries Inc. } \\
2001 \text { Center Road } \\
\text { Clinton, OH. } 44216\end{array}$ & N & - & I & - & \\
\hline $\begin{array}{l}\text { Woman's General Hospital } \\
1940 \text { E. lolst St. } \\
\text { Cleveland, OH. } 44106\end{array}$ & $\mathbf{N}$ & - & M & - & \\
\hline $\begin{array}{l}\text { John C. Haynes Co. } \\
800 \text { Hebron Road } \\
\text { Newark, OR. } 43055\end{array}$ & $\mathbf{N}$ & - & I & - & . \\
\hline $\begin{array}{l}\text { Peoples Hospital } \\
\text { Park Ave. East at Madison Rd. } \\
\text { Mansfield, OH. } 44905\end{array}$ & $Y$ & .2 & M & $\mathrm{N}$ & $\begin{array}{l}\text { Return to vendor } \\
\text { (Pharmatopes) }\end{array}$ \\
\hline $\begin{array}{l}\text { Bicron Corporation } \\
12345 \text { Kinsman Road } \\
\text { Newbury, OH. } 44065\end{array}$ & $\mathbf{N}$ & - & I & - & \\
\hline $\begin{array}{l}\text { The City Hospital } \\
\text { Bellaire, OH. } 43906\end{array}$ & $\mathbf{Y}$ & 2 & M & $\mathbf{N}$ & Vent, incinerate. \\
\hline $\begin{array}{l}\text { Ohio Ferro-Alloys Corp. } \\
\text { P. O. Box } 8228 \\
\text { Canton, OH. } 44709\end{array}$ & $Y$ & 2 & I & $\mathrm{N}$ & Return to vendor. \\
\hline $\begin{array}{l}\text { CVI Corporation } \\
100 \text { Lyman Court } \\
\text { Hilliard, OH. } 43026\end{array}$ & $\mathbf{N}$ & - & I & - & \\
\hline $\begin{array}{l}\text { Dayton Tire \& Rubber Co. } \\
2312 \text { west Rivervien Ave. } \\
\text { Dayton, OH. } 45407\end{array}$ & $\mathbf{N}$ & - & I & - & \\
\hline
\end{tabular}




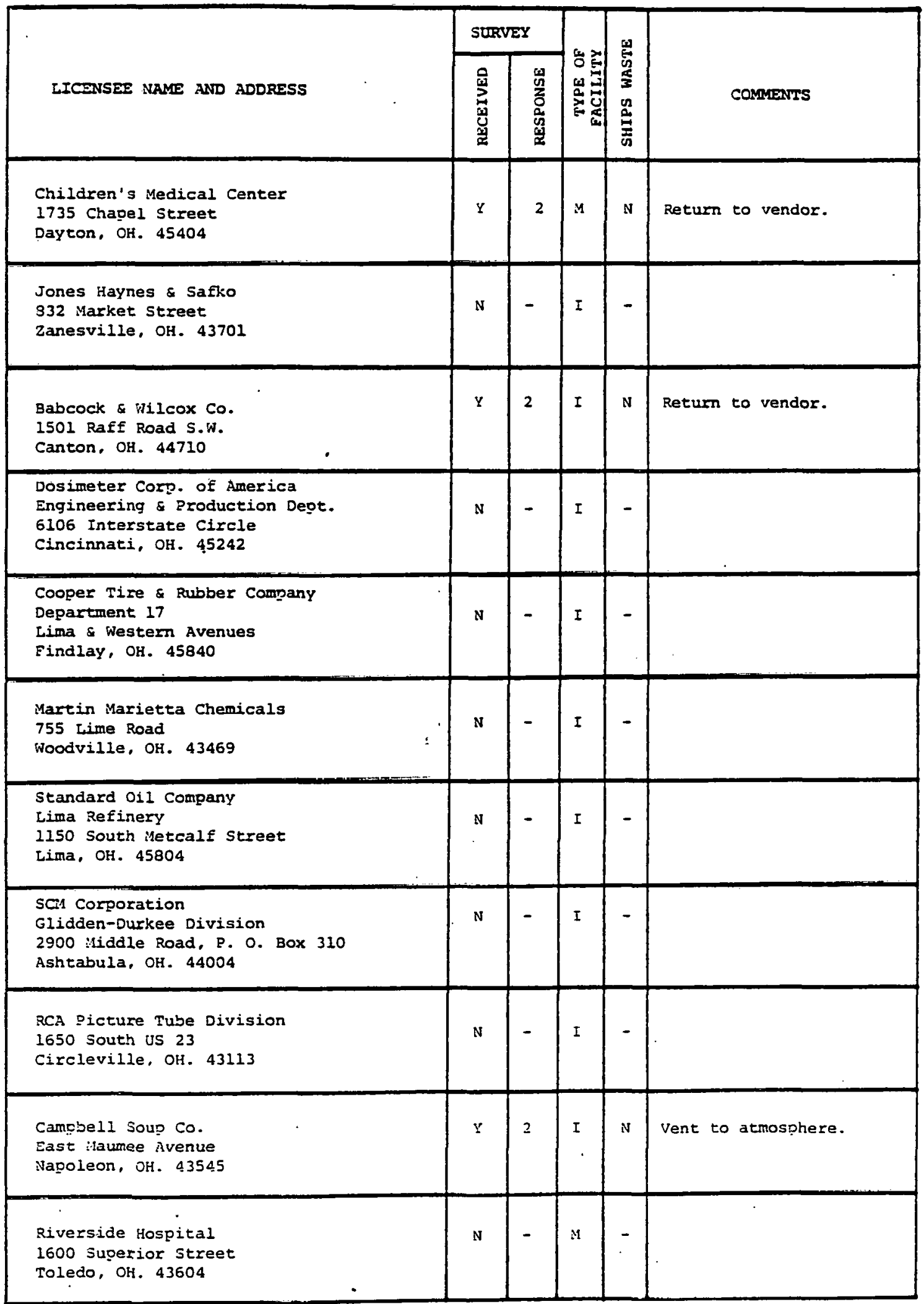




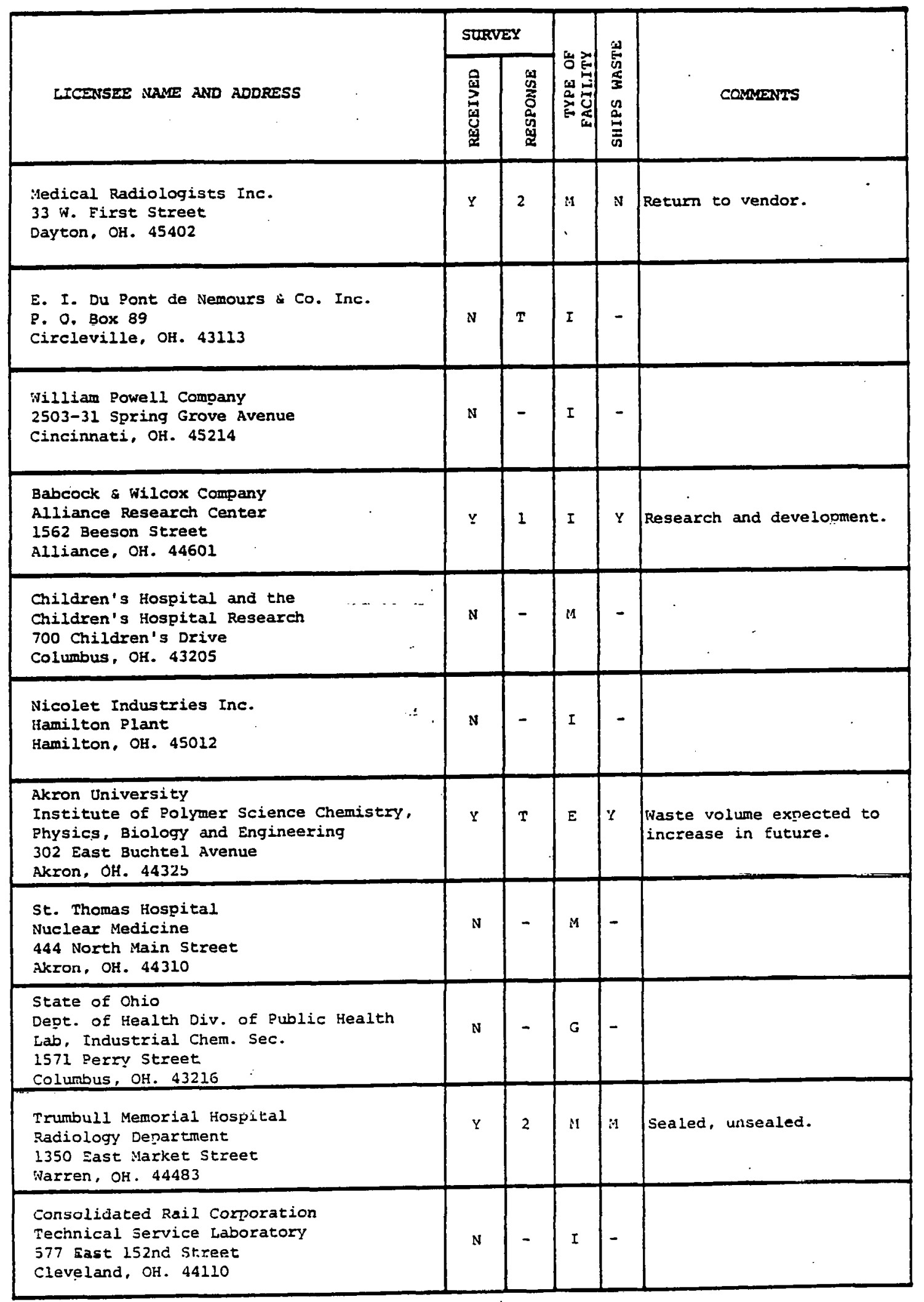




\begin{tabular}{|c|c|c|c|c|c|}
\hline \multirow[b]{2}{*}{ LICENSEE NAME AND ADDRESS } & \multicolumn{2}{|c|}{ SURVEY } & \multirow{2}{*}{$\mid \begin{array}{ll}0 \\
0 \\
0\end{array}$} & \multirow{2}{*}{ 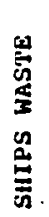 } & \multirow[b]{2}{*}{ COMagen's } \\
\hline & 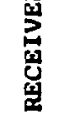 & $\begin{array}{l}\bar{n} \\
\text { 品 } \\
\text { 惫 }\end{array}$ & & & \\
\hline $\begin{array}{l}\text { Johns-Manville Siber Glass Inc. } \\
\text { River Road } \\
\text { Waterville, OH. } 43566\end{array}$ & $\mathbf{N}$ & - & I & - & \\
\hline $\begin{array}{l}\text { Overhoff \& Associates, Inc. } \\
\text { P. O. Box } 8091 \\
\text { Cincinnati, OH. } 45208\end{array}$ & $\mathbf{N}$ & - & I & - & \\
\hline $\begin{array}{l}\text { Reuter stokes Instruments Inc. } \\
\text { Instrument Assembly/Testing } \\
\text { 13530 South Miles Parkway } \\
\text { iarrensville, OH. } 44123\end{array}$ & $\mathbf{N}$ & - & I & - & \\
\hline $\begin{array}{l}\text { Clinton Memorial Hospital } \\
\text { Radiology Department } \\
610 \text { w. Main Street } \\
\text { Wilmington, OH. } 45177\end{array}$ & $\dot{Y}$ & 2 & M & $\mathrm{N}$ & Return to vendor. \\
\hline $\begin{array}{l}\text { Bio-Science Laboratory } \\
19701 \text { South Miles Road } \\
\text { Warrensville, OH. } 44128\end{array}$ & $\mathbf{N}$ & - & I & - & \\
\hline $\begin{array}{l}\text { Pharmatopes Inc. } \\
4172 \text { Crossgate Square } \\
\text { 9lue Ash. OH. } 45236\end{array}$ & $\mathbf{N}$ & - & I & - & \\
\hline $\begin{array}{l}\text { Sera Inc. } \\
3723-\mathrm{B} \text { Olentangy River Road } \\
\text { Columbus, OH. } 43214\end{array}$ & $\mathbf{N}$ & - & I & - & \\
\hline $\begin{array}{l}\text { Pharmatopes Inc. } \\
\text { I100. Rarig Road } \\
\text { Columbus, OH. } 43219\end{array}$ & $\Psi$ & 2 & I & $\mathrm{M}$ & Combine with refuse. \\
\hline $\begin{array}{l}\text { Isotec Corporation } \\
\text { lo29 Senate Drive } \\
\text { Centerville. OH. } 45459\end{array}$ & $\Psi$ & 2 & I & $\mathrm{N}$ & $\begin{array}{l}\text { As soon as license is } \\
\text { approved, will be } \\
\text { sending waste to } \\
\text { commercial repository. }\end{array}$ \\
\hline $\begin{array}{l}\text { Greene Hemorial Hospital Inc. } \\
\text { l14l North Honroe Drive } \\
\text { Xenia, OH. } 45385\end{array}$ & $\mathbf{Y}$ & 2 & i & $\mathrm{N}$ & Release to scwer. \\
\hline $\begin{array}{l}\text { Allied Technology Inc. } \\
\text { Manufacturing Department } \\
6104 \text { Poe Avenue } \\
\text { Dayton, OH. } 45414\end{array}$ & $\mathrm{~N}$ & - & I & - & \\
\hline
\end{tabular}




\begin{tabular}{|c|c|c|c|c|c|}
\hline \multirow[b]{2}{*}{ LICENSEE NAME AND ADDRESS } & \multicolumn{2}{|c|}{ SURVEY } & \multirow[b]{2}{*}{ 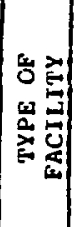 } & \multirow{2}{*}{ 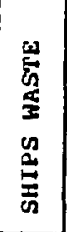 } & \multirow[b]{2}{*}{ COMAENTS } \\
\hline & 里 & 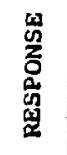 & & & \\
\hline $\begin{array}{l}\text { Ex-Lax Phamaceutical Company Inc. } \\
\text { Puality Assurance Laboratory } \\
\text { P. O. Box } 777 \\
\text { Dayton, OH. } 08810\end{array}$ & $\mathrm{~N}$ & - & I & - & \\
\hline $\begin{array}{l}\text { Buckeye well Surveys Inc. } \\
5115 \text { Oakridge Drive N.E. } \\
\text { Louisville, OH. } 44641\end{array}$ & $\mathbf{N}$ & - & I & - & \\
\hline $\begin{array}{l}\text { Rnox Commity Hospital } \\
200 \mathrm{~N} \text {. Mulberry St. } \\
\text { Mount Vernon, OH. } 43050\end{array}$ & $\mathbf{Y}$ & 2 & $M$ & $N$ & $\begin{array}{l}\text { Decay to background } \\
\text { levels. }\end{array}$ \\
\hline $\begin{array}{l}\text { Precision Reflex Inc. } \\
201 \text { North Main Street } \\
\text { New Bremen, OH. } 45869\end{array}$ & $\mathbf{N}$ & - & $I$ & - & \\
\hline $\begin{array}{l}\text { RS Holding Inc. } \\
\text { Electronic-Nuclear Testing Dept. } \\
18530 \text { South Miles Parkway } \\
\text { Cleveland, OH. } 44128\end{array}$ & $\mathbf{N}$ & - & $\mathbf{I}$ & - & \\
\hline $\begin{array}{l}\text { Northeastern Ohio Universities } \\
\text { College of Medicine } \\
\text { Rootstown. OH. } 44272\end{array}$ & $\mathbf{Y}$ & $\mathbf{T}$ & $E$ & $Y$ & \\
\hline $\begin{array}{l}\text { Lemorial Hospital of Sandusky County } \\
715 \text { Taft Avenue } \\
\text { Fremont, OH. } 43420\end{array}$ & M & - & $\mathbb{1 4}$ & - & \\
\hline $\begin{array}{l}\text { Richmond Heights General Hospital } \\
27100 \text { Chardon Road } \\
\text { Richmond Hts., OH. } 44143\end{array}$ & $\mathrm{~N}$ & - & $M$ & - & . \\
\hline $\begin{array}{l}\text { Rus/Mar Industries Inc. } \\
103 \text { Plymouth East Road, Rt. } 1 \\
\text { Plymoutin, OH. } 44865\end{array}$ & $\mathbf{N}$ & - & $\mathbf{I}$ & - & \\
\hline $\begin{array}{l}\text { Adria Laboratories Inc. } \\
6071 \text { State Rt. } 161 \mathrm{E.} \\
\text { Plain City, OH. } 43064\end{array}$ & $Y$ & 2 & I & $N$ & $\begin{array}{l}\text { Release to sewer: } \\
\text { burn on-site. }\end{array}$ \\
\hline $\begin{array}{l}\text { Euclid General Hospit.al } \\
101 \text { E. 185th Street } \\
\text { Euclid, OH. } 44119\end{array}$ & $Y$ & $T$ & $M$ & $\mathrm{~N}$ & Unsealed sources. \\
\hline
\end{tabular}




\begin{tabular}{|c|c|c|c|c|c|}
\hline \multirow[b]{2}{*}{ LICENSEE NAME AND ADDRESS } & \multicolumn{2}{|c|}{ SURVEY } & \multirow{2}{*}{ 穷苞 } & \multirow{2}{*}{ 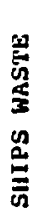 } & \multirow[b]{2}{*}{ COMAENTSS } \\
\hline & 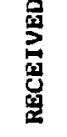 & 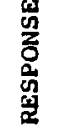 & & & \\
\hline $\begin{array}{l}\text { Bio-Nuclear Assays Inc. } \\
3728 \text { B Olentangy River Rd. } \\
\text { Columbus, OH. } 43214\end{array}$ & $\mathbf{N}$ & - & I & - & \\
\hline $\begin{array}{l}\text { Deaconess Hospital of Cleveland } \\
4229 \text { Pearl Road } \\
\text { Cleveland, OH. } 44109\end{array}$ & $Y$ & 2 & M & $\mathbf{N}$ & Return to vendor. \\
\hline $\begin{array}{l}\text { Cleveland Regional Sewer District } \\
6000 \text { Canal Road } \\
\text { CuYahoga Heights, OH. } 44233\end{array}$ & $\mathbf{N}$ & - & c & - & \\
\hline $\begin{array}{l}\text { Crystaloid Electronics Company } \\
4976 \text { Hudson Drive } \\
\text { Stow, OH. } 44224\end{array}$ & $Y$ & 2 & I & $\mathbf{N}$ & No waste generated. \\
\hline $\begin{array}{l}\text { Perstoro Inc. } \\
\text { Toledo Division } \\
600 \text { Matzinger Road } \\
\text { Toledo, OH. } 43612\end{array}$ & $\mathbf{N}$ & - & I & - & \\
\hline $\begin{array}{l}\text { Radiology Physicians Inc. } \\
30 \text { West Rahn Road } \\
\text { Kettering, OH. } 45429\end{array}$ & $\mathbf{Y}$ & 2 & il & is & $\begin{array}{l}\text { Return to vendor. } \\
\text { Decay to background } \\
\text { level. }\end{array}$ \\
\hline $\begin{array}{l}\text { Community Hospital of Bedford Inc. } \\
44 \text { Blaine Street } \\
\text { Bedford, OH. } 44146\end{array}$ & $\mathbf{N}$ & - & M & - & \\
\hline $\begin{array}{l}\text { Lorain Community Hospital } \\
3700 \text { Kolbe Road } \\
\text { Lorain, OH. } 44053\end{array}$ & $\mathbf{N}$ & - & is & - & \\
\hline $\begin{array}{l}\text { Quality Testing Inc. } \\
\text { SO21 w. 161st Street } \\
\text { Cleveland, OH. } 44142\end{array}$ & $\mathrm{~N}$ & - & I & - & \\
\hline $\begin{array}{l}\text { Piqua Memorial Hostital } \\
624 \text { Park Avenue } \\
\text { Piqua, OH. } 45356\end{array}$ & is & - & $M$ & - & \\
\hline $\begin{array}{l}\text { City of Bryan Ohio } \\
103 \mathrm{~N} \text {. Beech St. . P. O. Box. } 190 \\
\text { Bryan, OH. } 43506 \\
\quad .\end{array}$ & $Y$ & 2 & $c$ & $\mathbb{N}$ & $\begin{array}{l}\text { Sealed source used in } \\
\text { equipment. }\end{array}$ \\
\hline
\end{tabular}




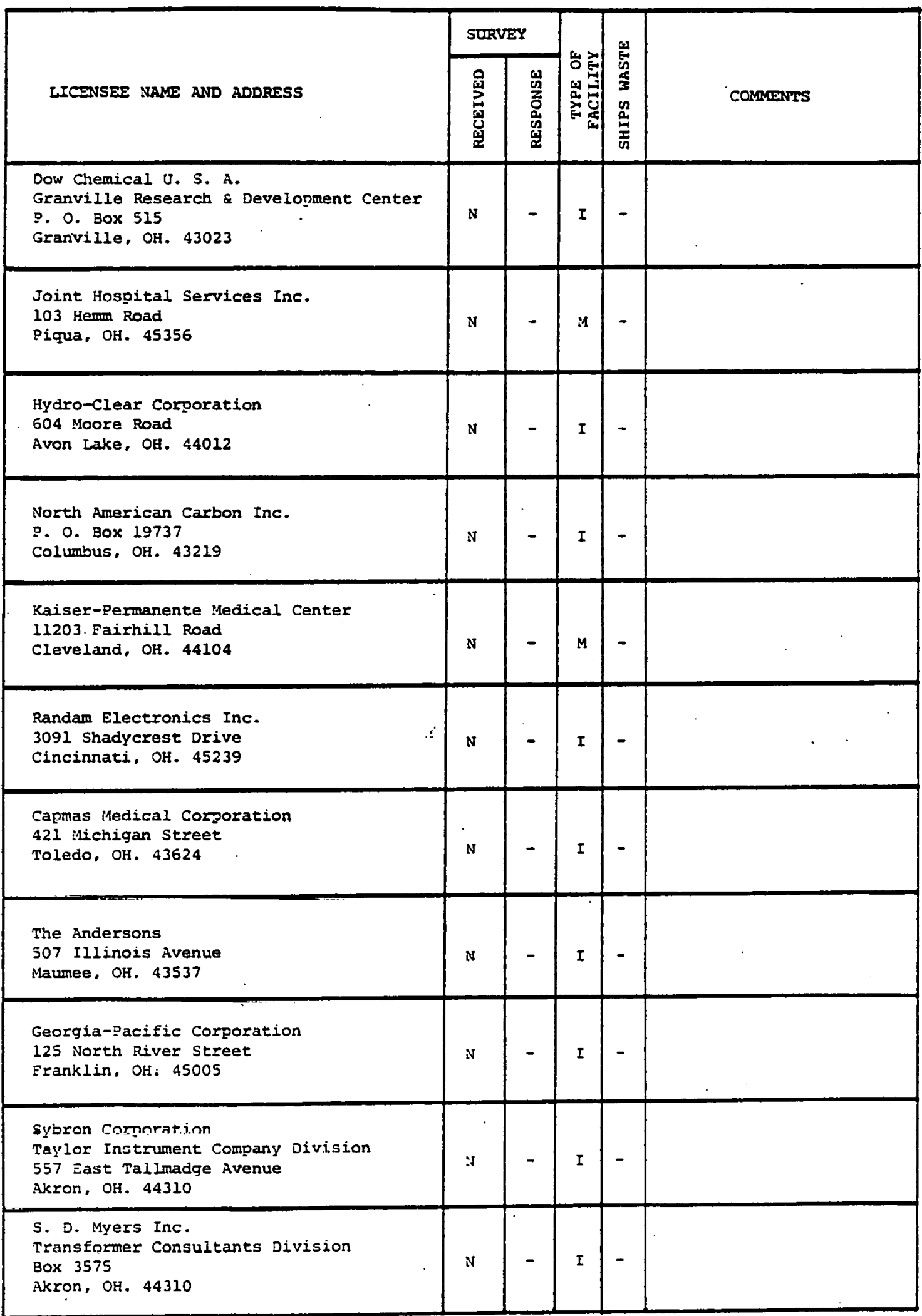




\begin{tabular}{|c|c|c|c|c|c|}
\hline \multirow[b]{2}{*}{ IICONSEE ILAME AND ADDRESS } & \multicolumn{2}{|c|}{ SURVEY } & \multirow[b]{2}{*}{ 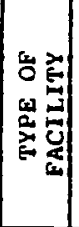 } & \multirow{2}{*}{ 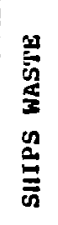 } & \multirow[b]{2}{*}{ COMRIENTSS } \\
\hline & 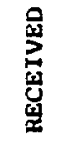 & 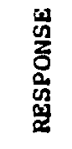 & & & \\
\hline $\begin{array}{l}\text { Davidson Laboratory } \\
267 \text { E. Broad Street } \\
\text { Columbus, OH. } 43215\end{array}$ & $\mathrm{~N}$ & - & M & - & - \\
\hline $\begin{array}{l}\text { Parkview Hospital } \\
1920 \text { Parkwood Avenue } \\
\text { Toledo, OH. } 43624\end{array}$ & $\mathbf{N}$ & - & M & - & \\
\hline $\begin{array}{l}\text { Ohio Valley Hospital } \\
\text { Radiology Deoartment } \\
380 \text { Sumit Avenue } \\
\text { Steubenville, OH. } 43952\end{array}$ & $\mathrm{Y}$ & $\mathbf{T}$ & $M$ & $\mathbf{N}$ & Return to vendor. \\
\hline $\begin{array}{l}\text { Sharon Steel Corporation } \\
\text { Brainard Strapping Division } \\
\text { Larchmont Avenue } \\
\text { ivarren, OH. } 44482\end{array}$ & $?$ & 2 & $\mathbf{I}$ & $\mathbf{N}$ & Return to vencior. \\
\hline $\begin{array}{l}\text { Doctors Hospital Inc. } \\
420 \text { Austin Avenue, N. } \mathrm{N} \text {. } \\
\text { Massillon, OH. } 44640\end{array}$ & $\mathbf{N}$ & - & I & - & . \\
\hline $\begin{array}{l}\text { St. Joseph Riverside Hospital } \\
\text { Dept. of Radiology } \\
\text { l400 Tod Avenue N.W. } \\
\text { Warren, OH. } 44485\end{array}$ & 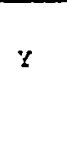 & $\mathbf{T}$ & I & $\mathbf{N}$ & $\begin{array}{l}\text { Unsealed sources. } \\
\text { Return to vendor. }\end{array}$ \\
\hline $\begin{array}{l}\text { United States Gypsum Company } \\
\text { Genoa, OH. } 43430\end{array}$ & $\mathbf{N}$ & - & I & - & \\
\hline $\begin{array}{l}\text { Medical College of Ohio at Toledo } \\
\text { Department of Radiology } \\
\text { P. O. Box } 6190 \\
\text { Toledo. OH. } 43614\end{array}$ & $Y$ & 2 & $M$ & $\mathbf{N}$ & $\begin{array}{l}\text { Release to sewer. Decay } \\
\text { to background level, burn. }\end{array}$ \\
\hline $\begin{array}{l}\text { Shell Chemical Company } \\
2982 \text { iashington Boulevard } \\
\text { Belpre, OH. } 45714\end{array}$ & $Y$ & 2 & I & $\mathrm{N}$ & Return to vendor. \\
\hline $\begin{array}{l}\text { Wilson Memorial Hosoital } \\
915 \text { West Michigan Street } \\
\text { Sidney, OH. } 45365\end{array}$ & $Y$ & 2 & $\mathrm{i}$ & $\mathrm{N}$ & \\
\hline $\begin{array}{l}\text { City of Columbus Ohio } \\
\text { Dept. of Public Service } \\
\text { City Hall } \\
\text { Columbus, OH. } 43215\end{array}$ & $\mathrm{Y}$ & 2 & G & $\mathrm{N}$ & . \\
\hline
\end{tabular}




\begin{tabular}{|c|c|c|c|c|c|}
\hline \multirow[b]{2}{*}{ IICENSEE NAME AND ADDRESS } & \multicolumn{2}{|c|}{ SURVEY } & \multirow{2}{*}{ 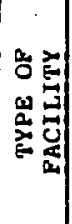 } & \multirow{2}{*}{ 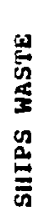 } & \multirow[b]{2}{*}{ COMMENTSS } \\
\hline & 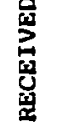 & 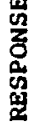 & & & \\
\hline $\begin{array}{l}\text { Osco Industries Inc. } \\
\text { lith \& Chillicothe Street } \\
\text { Portsmouth. OH. } 45662\end{array}$ & $Y$ & 2 & I & $\mathbf{N}$ & Return to vendor. \\
\hline $\begin{array}{l}\text { Dayton Testing Laboratory } \\
5551 \text { Nebster Street } \\
\text { Dayton, он. } 45414\end{array}$ & $\Psi$ & 2 & I & w & \\
\hline $\begin{array}{l}\text { Dr. T. C. Hobbs \& Associates, Inc. } \\
\text { Nuclear Medicine } \\
5340 \text { E. Main Street } \\
\text { Columbus, OH. } 43213\end{array}$ & N & - & $M$ & - & \\
\hline $\begin{array}{l}\text { E. C. Gerken \& Associates Inc. } \\
1939 \text { a. East Second Street } \\
\text { Defiance, OH. } 43512\end{array}$ & $\Psi$ & 2 & I & $\mathrm{N}$ & \\
\hline $\begin{array}{l}\text { Jones \& Henry Laboratories Inc. } \\
2000 \text { w. Central Avenue } \\
\text { Toledo, OH. } 43606\end{array}$ & $\mathbf{Y}$ & 2 & I & $\mathbf{N}$ & \\
\hline $\begin{array}{l}\text { Black Clawson Shartle } \\
\text { Pandia Division } \\
605 \text { Clark Street } \\
\text { Middletown, OH. } 45042\end{array}$ & $\Psi$ & 2 & I & $\mathbf{N}$ & \\
\hline $\begin{array}{l}\text { Ohio valley Paving Corporation } \\
343 \text { w. Main Street } \\
\text { St. Clairsville, OH. } 43950\end{array}$ & $\mathrm{~N}$ & - & I & - & \\
\hline $\begin{array}{l}\text { L. R. Skelton \& Company } \\
3099 \text { Sullivant Avenue } \\
\text { Columbus, OH. } 43204\end{array}$ & $\mathbf{Y}$ & 2 & I & $\mathbf{N}$ & Return to vendor. \\
\hline $\begin{array}{l}\text { Tremco Inc. } \\
10701 \text { Shaker Boulevard } \\
\text { Cloveliand, OH. } 44104\end{array}$ & N & - & I & - & \\
\hline $\begin{array}{l}\text { Sterling Drug Inc. } \\
\text { H1lton-Davis Chemical Company Division } \\
2235 \text { Langdon Farm Road } \\
\text { Cincinnati, OH. } 45237\end{array}$ & N & - & I & - & \\
\hline $\begin{array}{l}\text { Medical Diagnostic Services } \\
143 \text { Westpark Road } \\
\text { Centerville. OH. } 45459 \\
\text {. }\end{array}$ & $\mathrm{N}$ & - & $M$ & - & \\
\hline
\end{tabular}




\begin{tabular}{|c|c|c|c|c|c|}
\hline \multirow[b]{2}{*}{ IICENSEE NANE AND ACDDRESS } & \multicolumn{2}{|c|}{ SURVEY } & \multirow{2}{*}{ 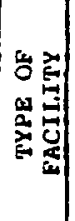 } & \multirow{2}{*}{ 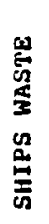 } & \multirow[b]{2}{*}{ COMMENTS } \\
\hline & 欲 & 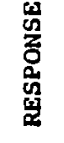 & & & \\
\hline $\begin{array}{l}\text { Analytical Laboratories of Ohio } \\
15322 \text { St. Clair Avenue } \\
\text { Cleveland, OH. } 44110\end{array}$ & $\mathbf{Y}$ & 1 & I & $\underline{Y}$ & \\
\hline $\begin{array}{l}\text { St. Ann's Hospital } \\
1555 \text { Bryden Road } \\
\text { Columbus, OH. } 43205\end{array}$ & $\mathbf{N}$ & $\mathbf{T}$ & $M$ & - & $\begin{array}{l}\text { Refused to answer } \\
\text { survey. }\end{array}$ \\
\hline $\begin{array}{l}\text { Shelly \& Sands Ine. } \\
\text { D. O. Box } 951 \\
\text { Zanesville, OH. } 43701\end{array}$ & $\mathbf{N}$ & - & I & - & \\
\hline $\begin{array}{l}\text { Memorial Hospital of Union County } \\
\text { London Avenue } \\
\text { Marysuille, OH. } 43040 \\
\end{array}$ & N & $\rightarrow$ & $M$ & - & 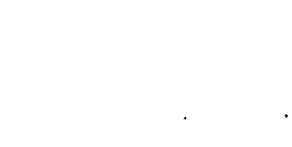 \\
\hline $\begin{array}{l}\text { Bowser-Morner Testing Läboratories Inc. } \\
\dot{4} 20 \text { Davis Avenue } \\
\text { Dayton, OH. } 45401\end{array}$ & $\mathbf{N}$ & - & I & - & . \\
\hline $\begin{array}{l}\text { Ares Inc. } \\
\text { P. O. Box } 459 \\
\text { Port Clinton, OH. } 43452\end{array}$ & $\mathbf{N}$ & - & I & - & \\
\hline $\begin{array}{l}\text { Clermont County Hospital } \\
3000 \text { Hospital Drive } \\
\text { Batavia, OH. } 45103\end{array}$ & $\mathrm{~N}$ & - & M & - & \\
\hline $\begin{array}{l}\text { Shelly Company } \\
\text { P. O. Box } 266 \\
\text { Thronville, OH. } 43076\end{array}$ & $\mathbf{Y}$ & 2 & - & $\mathbf{N}$ & \\
\hline $\begin{array}{l}\text { Neurosurgical Clinic \& Associates Inc. } \\
153 \text { North Fourth Street } \\
\text { Steubenville, OH. } 43952\end{array}$ & $\mathrm{~N}$ & - & M & - & $\cdot$ \\
\hline $\begin{array}{l}\text { Blood Alliance Inc. } \\
3204 \text { w. } 25 \text { th Street } \\
\text { Cleveland, OH. } 44109\end{array}$ & $N$ & - & $M$ & - & \\
\hline $\begin{array}{l}\text { CAR-MI Inc. } \\
5640 \text { Brentinger Drive } \\
\text { Dayton, OH. } 45414\end{array}$ & $\mathrm{~N}$ & - & I & - & . \\
\hline
\end{tabular}




\begin{tabular}{|c|c|c|c|c|c|}
\hline & sur & & & & \\
\hline LICENSEE NAME AND ADDRESS & 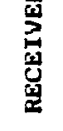 & 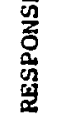 & 番 & $\begin{array}{l}\tilde{3} \\
0 \\
\stackrel{2}{*}\end{array}$ & COMninNTs \\
\hline $\begin{array}{l}\text { Cargill Inc.' } \\
3201 \text { Needmore Road. } \\
\text { Box } 1400-A \\
\text { Dayton, OH. } 45414\end{array}$ & $\mathrm{~N}$ & - & I & - & \\
\hline $\begin{array}{l}\text { Dresser Industries Inc. } \\
\text { Galion Mfg. Division } \\
352 \text { South St. } \\
\text { Galion, Ok. } 44833\end{array}$ & $\mathbf{N}$ & - & I & - & \\
\hline $\begin{array}{l}\text { Quaker Oats Company } \\
\text { I171 w. Center Street } \\
\text { Marion, OH. } 43302\end{array}$ & $\mathbf{Y}$ & 2 & - & $\mathbf{N}$ & $\begin{array}{l}\text { Sealed sources. } \\
\text { Process control. }\end{array}$ \\
\hline $\begin{array}{l}\text { Mary Rutan Hospital } \\
205 \text { Palmer Avenue } \\
\text { Bellefontaine, OH. } 43311\end{array}$ & $\mathbf{N}$ & - & i & - & \\
\hline $\begin{array}{l}\text { Vanwert County Hospital } \\
1250 \text {. South Washington Street } \\
\text { Vanwert, CH. } 45891\end{array}$ & $Y$ & 2 & $u$ & N & $\begin{array}{l}\text { Combine with refuse: } \\
\text { return to vendor. }\end{array}$ \\
\hline $\begin{array}{l}\text { Eedco-Environmental Inc. } \\
11499 \text { Chester Road } \\
\text { Cincinnati. OH: } 45246\end{array}$ & $\mathbf{N}$ & - & I & - & \\
\hline $\begin{array}{l}\text { St. Luke's Hospital } \\
5901 \text { Monclova Road } \\
\text { Maumee, OH. } 43537\end{array}$ & $\mathbf{Y}$ & 2 & 4 & $\mathbf{N}$ & $\begin{array}{l}\text { Return to vendor. } \\
\text { Decay to background } \\
\text { level. }\end{array}$ \\
\hline $\begin{array}{l}\text { Russell, Burdsall \& Ward Inc. } \\
\text { 8100 TYler Boulevard } \\
\text { Mentor, OH. } 44060\end{array}$ & $\mathbf{N}$ & - & I & - & \\
\hline $\begin{array}{l}\text { Veterans Memorial Hospital } \\
\text { Mulberry Heights } \\
\text { Pomeroy, OH. } 45769\end{array}$ & $\mathbf{N}$ & - & i & - & \\
\hline $\begin{array}{l}\text { Schoen Paving Inc. } \\
310 \text { South Nestwood Avenue } \\
\text { Toledo, OH. } 43609\end{array}$ & $\mathbb{N}$ & - & I & - & \\
\hline $\begin{array}{l}\text { Randam Electronics Inc. } \\
3091 \text { Shadycrest Drive } \\
\text { Cincinnati, OH. } 45239\end{array}$ & $\mathrm{~N}$ & - & I & - & \\
\hline
\end{tabular}




\begin{tabular}{|c|c|c|c|c|c|}
\hline & sur & & & & \\
\hline LICENSEE NAME AND ADDRESS & 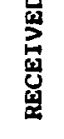 & 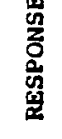 & 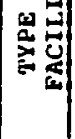 & 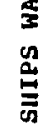 & COMMENTIS \\
\hline $\begin{array}{l}\text { Madison County Hospital } \\
210 \mathrm{~N} \text {. Main Street } \\
\text { London, OH. } 43140\end{array}$ & $\mathbf{N}$ & - & $M$ & - & . \\
\hline $\begin{array}{l}\text { Qual-X Inc. } \\
4065 \text { North Leap Road } \\
\text { Hilliard, OH. } 43026\end{array}$ & $\mathbf{N}$ & - & $\mathbf{I}$ & - & \\
\hline $\begin{array}{l}\text { Fulton County Health Center } \\
725 \text { South Shood Avenue } \\
\text { Wauseon. OH. } 43567\end{array}$ & $x$ & 2 & M & $\mathbf{N}$ & $\begin{array}{l}\text { Combine with refuse, } \\
\text { return to vendor. }\end{array}$ \\
\hline $\begin{array}{l}\text { Vulcan Mfg. Co. } \\
\text { P. O. Box } 46465 \text { Glendale Rd. Wdiwn } \\
\text { Cincinnati, OH. } 45246\end{array}$ & $\mathbf{x}$ & 2 & I & $\mathrm{N}$ & \\
\hline $\begin{array}{l}\text { Anderson-Bolds Inc. } \\
5720 \text { Dragon Way } \\
\text { Cincinnati, OH. } 45227\end{array}$ & $\mathbf{N}$ & - & I & - & \\
\hline $\begin{array}{l}\text { Stilson Laboratories Inc. } \\
170 \text { North High Street } \\
\text { Columbus, OH. } 43215\end{array}$ & $\Psi$ & 2 & I & $\mathrm{N}$ & Return to vendor. \\
\hline $\begin{array}{l}\text { Tri-State Asphalt Corporation } \\
\text { East Jefferson Street } \\
\text { Martins Ferry, OH. } 43935\end{array}$ & $\Psi$ & 2 & I & $\mathbf{N}$ & No waste generated. \\
\hline $\begin{array}{l}\text { Licking Memorial Hospital } \\
1320 \text { West Main Street } \\
\text { Newark, OH. } 43055\end{array}$ & $Y$ & $\mathbf{T}$ & "1 & $\mathrm{N}$ & $\begin{array}{l}\text { Unsealed sources } \\
\text { irradicated. }\end{array}$ \\
\hline $\begin{array}{l}\text { Ohio Valley Testing Laboratory Inc. } \\
\text { P. O. Box } 93-120 \text { Third St. } \\
\text { Marietta, OH. } 45750\end{array}$ & $\mathbf{N}$ & - & I & - & \\
\hline $\begin{array}{l}\text { Newport News Industrial Corp. of Ohio } \\
\text { p. D. Box } 25 \\
\text { Peryy, OH. } 44081\end{array}$ & $\mathrm{~N}$ & - & I & - & \\
\hline $\begin{array}{l}\text { City of Lima Ohio } \\
\text { Utiiities Department } \\
219 \text { East Warket Street } \\
\text { Lima, OH. } 45807 \text {. }\end{array}$ & $Y$ & 2 & G & $\mathrm{N}$ & \\
\hline
\end{tabular}




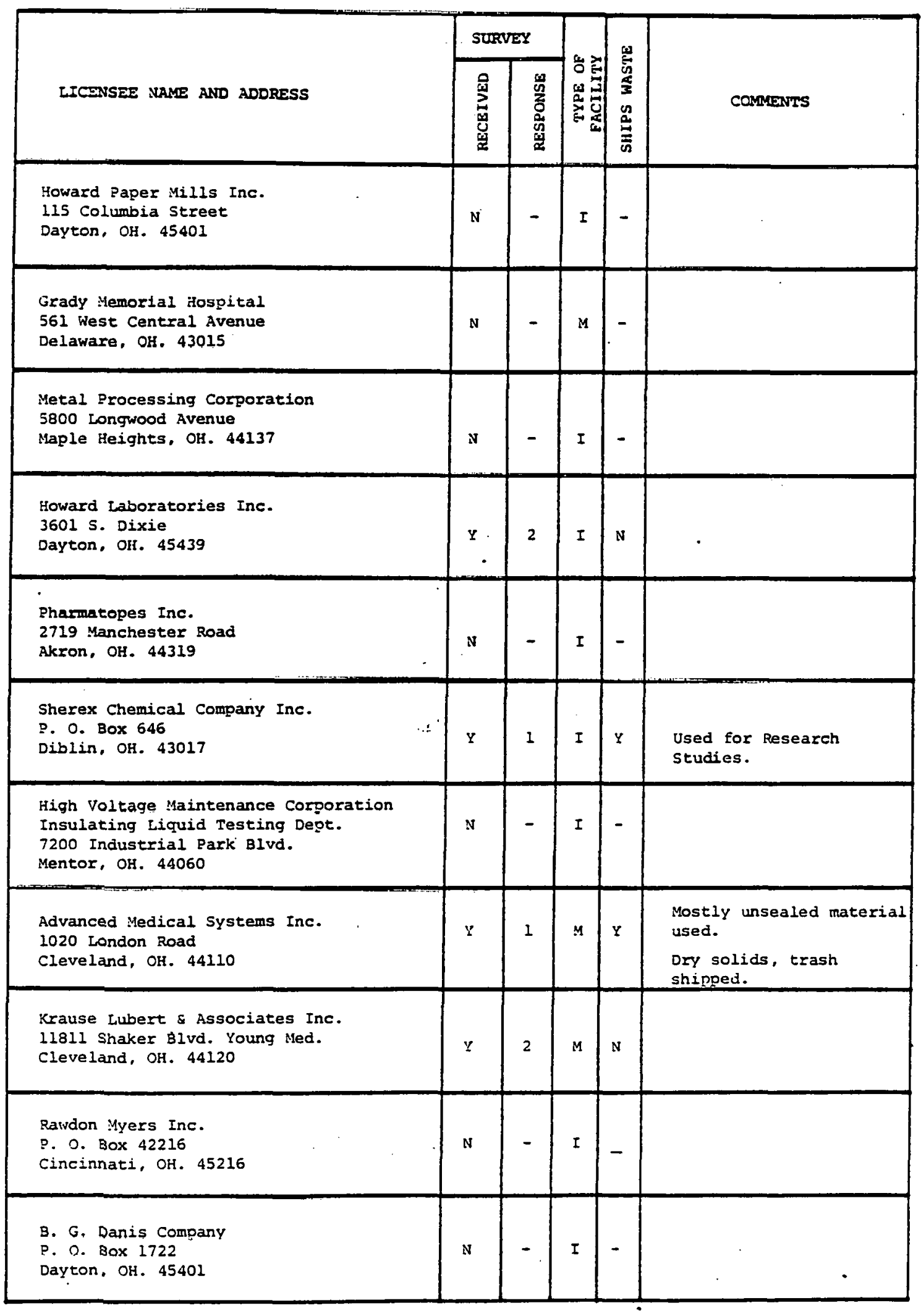




\begin{tabular}{|c|c|c|c|c|c|}
\hline \multirow[b]{2}{*}{ LICDNSEE NAME AND ADDRESS } & \multicolumn{2}{|c|}{ SURVEY } & \multirow{2}{*}{ 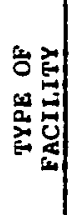 } & \multirow{2}{*}{ 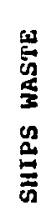 } & \multirow[b]{2}{*}{ COMAnENTS } \\
\hline & 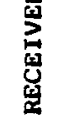 & 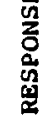 & & & \\
\hline $\begin{array}{l}\text { Benedict, Bowman, Crag \& Moos } \\
195 \text { Chittenden Avenue, } \\
\text { Columbus, OH. } 43201\end{array}$ & $\mathbf{Y}$ & 2 & - & i & $\begin{array}{l}\text { Return to vendor. } \\
\text { Sealed sources used. }\end{array}$ \\
\hline $\begin{array}{l}\text { Joint Twp. Dist. Memorial Hospital } \\
\text { flager \& St. Clair Sts. } \\
\text { St. Mary's, OH. } 45891\end{array}$ & $\mathbf{N}$ & - & $\mathbf{M}$ & - & v \\
\hline $\begin{array}{l}\text { Alan Stone Co. Inc. } \\
\text { S. R. } 377-\text { P. O. BOx } 127 \\
\text { Chesterhil1, ОН. } 43728\end{array}$ & $Y$ & 2 & I & u & \\
\hline $\begin{array}{l}\text { Systems Engineering Associates } \\
7349 \text { Worthington-Galena Road } \\
\text { Columbus, OH. } 43085\end{array}$ & N & - & I & - & \\
\hline $\begin{array}{l}\text { Systems Technology Corporation } \\
245 \text { North Valley Road } \\
\text { Xenia, OH. } 45385\end{array}$ & $\mathbf{N}$ & - & I & $1-$ & . \\
\hline $\begin{array}{l}\text { Dodson-Lindblom Associates, Inc. } \\
5 \text { East Long Street } \\
\text { Columbus, OH. } 43225\end{array}$ & is & - & I & - & \\
\hline $\begin{array}{l}\text { Pharmatopes Inc. } \\
300 \text { Forest Avenife } \\
\text { Dayton, OH. } 45405\end{array}$ & $\mathrm{Y}$ & 2 & I & $\mathrm{N}$ & $\begin{array}{l}\text { Combine with refuse: } \\
\text { return to vendor. }\end{array}$ \\
\hline $\begin{array}{l}\text { Pollution Control Science Inc. } \\
6015 \text { Manning Road } \\
\text { Miamisburg, OH. } 45342\end{array}$ & $\mathbf{N}$ & - & I & - & · \\
\hline $\begin{array}{l}\text { Lubrizol Corporation } \\
\text { P. O. Box } 428 \\
\text { Painesville, OH. } 44077\end{array}$ & N & - & $I$ & $1-$ & \\
\hline $\begin{array}{l}\text { Hessmore Testing \& Supervision Inc. } \\
265 \text { E. Market Street } \\
\text { Akron, OH. } 4430 B\end{array}$ & Y & 2 & I & $\mathrm{N}$ & $\begin{array}{l}\text { Return to vendor. } \\
\text { Sealed source. }\end{array}$ \\
\hline $\begin{array}{l}\text { Otto C. Epo Memorial liospital } \\
3000 \text { Kenwood Road } \\
\text { Cincinnati, OH. } 45236 \\
.\end{array}$ & $y$ & 2 & $M$ & $\mathrm{~N}$ & Sealed sources. \\
\hline
\end{tabular}




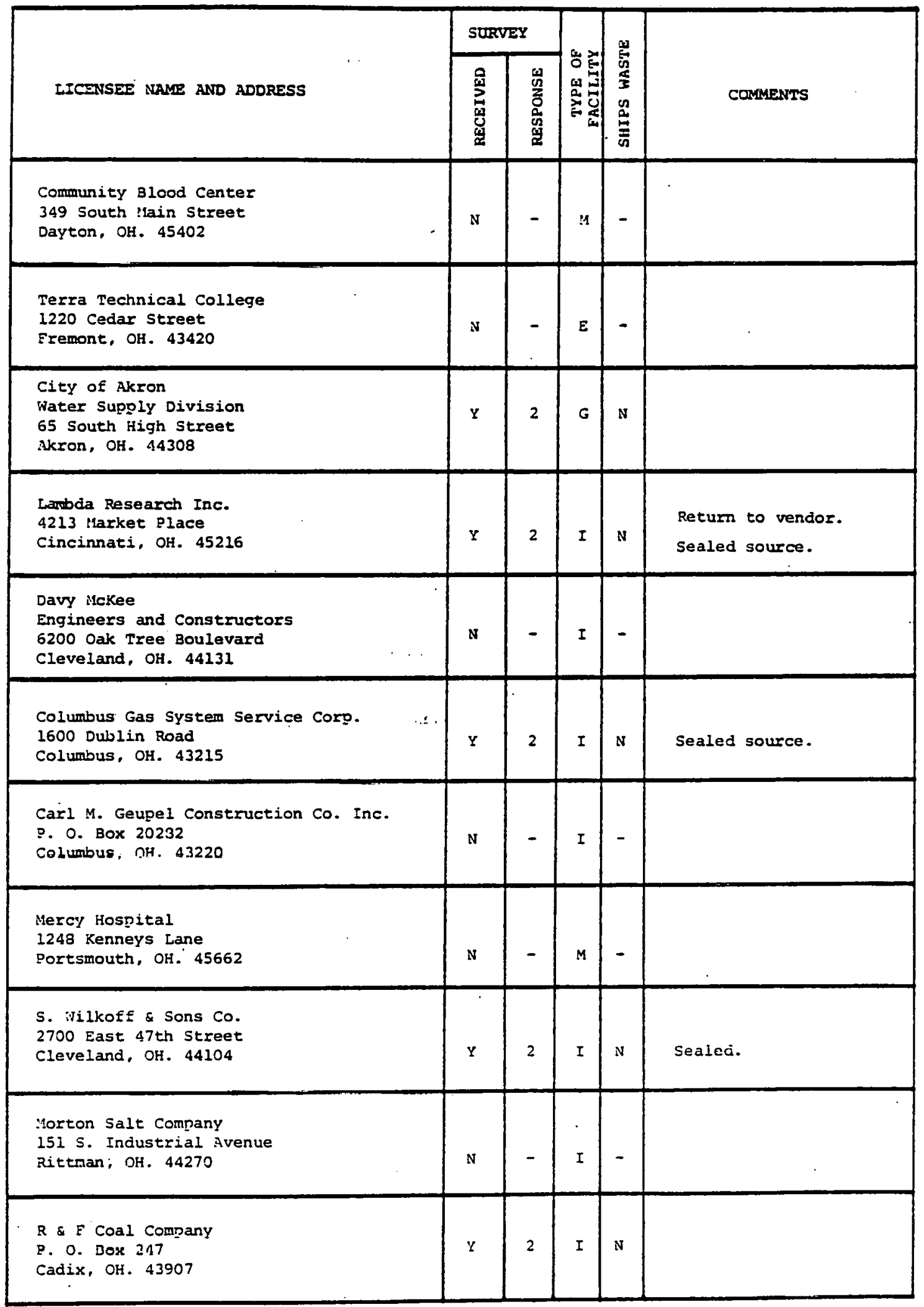




\begin{tabular}{|c|c|c|c|c|c|}
\hline & sur & & & is & \\
\hline LICENSEE NAME AND ADDRESS & 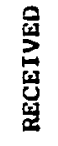 & 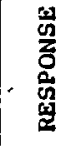 & 至式 & 点 & comarentss \\
\hline $\begin{array}{l}\text { Owens-Corning Eiberglas Corp. } \\
\text { Eiberglas Tower } \\
\text { Toledo, OH. } 43659\end{array}$ & ì & - & I & - & \\
\hline $\begin{array}{l}\text { Armco Inc. } \\
\text { P. O. Box } 1529 \\
\text { Zanesville, OH. } 43701\end{array}$ & $Y$ & 2 & I & $\mathbf{N}$ & $\begin{array}{l}\text { Return to vendor. } \\
\text { Sealed source. }\end{array}$ \\
\hline $\begin{array}{l}\text { Nadsworth Testing Laboratories Inc. } \\
16004 \text { th St., S.E. } \\
\text { P. O. Box } 20 \\
\text { Canton, OH. } 44701\end{array}$ & $\mathbf{N}$ & - & $I$ & - & . \\
\hline $\begin{array}{l}\text { HeCallough-Hyde Hospital } \\
110 \text { W. Poplar Street } \\
\text { oxford. OH. } 45056\end{array}$ & $\mathbf{N}$ & - & M & - & \\
\hline $\begin{array}{l}\text { Central Ohio Medical Clinic } \\
497 \text { D. Towi } 3 t . \\
\text { Columbus, OH. } 43215\end{array}$ & $\mathbf{N}$ & - & $M$ & - & \\
\hline $\begin{array}{l}\text { Packard Electric Div. of General :Hotors } \\
\text { Box } 431 \\
\text { Warren, OH. } 44482\end{array}$ & $\mathrm{~N}$ & - & $I$ & - & \\
\hline $\begin{array}{l}\text { Springborn Institute for } \\
\text { Bioresearch Inc. } \\
553 \text { North Broadway } \\
\text { Spencerville, OH. } 45887\end{array}$ & $\mathbf{N}$ & - & $I$ & - & \\
\hline $\begin{array}{l}\text { Cravat Coal Company } \\
\text { Road } 4 \\
\text { Cadiz, OH. } 43907\end{array}$ & $\mathrm{~N}$ & - & $I$ & - & . \\
\hline $\begin{array}{l}\text { Anderson-Lynn Inc. } \\
\text { ?. O. Box } 166 \\
\text { Piketon, OH. } 45661\end{array}$ & is & - & I & - & \\
\hline $\begin{array}{l}\text { Standard Slag Company Inc. } \\
\text { l200 Stambasth Building } \\
\text { youngstom, OII. } 44503\end{array}$ & $\mathbf{N}$ & - & $I$ & - & \\
\hline $\begin{array}{l}\text { Dalton, Dalton, Newport Inc. } \\
34 \mathrm{v} \text {. Hawkins Avenue } \\
\text { Akron, OH. } 44313\end{array}$ & $\mathbf{N}$ & - & I & - & \\
\hline
\end{tabular}




\begin{tabular}{|c|c|c|c|c|c|}
\hline \multirow[b]{2}{*}{ IICENSEE NAME AND ADDRESS } & \multicolumn{2}{|c|}{ SURVEY } & \multirow[b]{2}{*}{ 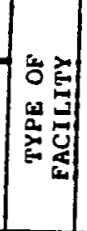 } & \multirow[b]{2}{*}{ 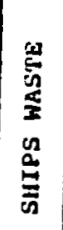 } & \multirow[b]{2}{*}{ COMMENTS } \\
\hline & 畧 & 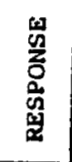 & & & \\
\hline $\begin{array}{l}\text { Mobile Medical Imaging of Ohio Inc. } \\
1330 \text { Dublin Road, Suite } 108 \\
\text { Columbus, OH. } 43215\end{array}$ & v & - & $M$ & - & \\
\hline $\begin{array}{l}\text { Samaritan. Hospital } \\
\text { Dept. of Radiology \& Nuclear Medicine } \\
1025 \text { Conter Street } \\
\text { Ashland, OH. } 44805\end{array}$ & $Y$ & 2 & $\mathbf{M}$ & $\mathbf{N}$ & . \\
\hline $\begin{array}{l}\text { O. H. Saterials Inc. } \\
\text { Chemistry Laboratory } \\
\text { State Route } 224 \text { East } \\
\text { Findlay, OH. } 45840\end{array}$ & $\mathbf{N}$ & - & I & - & \\
\hline $\begin{array}{l}\text { City of Canton Water Department } \\
\text { Laboratory Division } \\
2664 \text { Harrisburg Road, N.E. } \\
\text { Canton, OH. } 44705\end{array}$ & $y$ & 2 & G. & $\mathrm{N}$ & $\begin{array}{l}\text { Return to vendor. } \\
\text { Sealed sources. }\end{array}$ \\
\hline $\begin{array}{l}\text { Maumee River Wastewater Treatment Plant } \\
5858 \text { North River Road } \\
\text { Waterville, OH. } 43566\end{array}$ & $\mathbf{N}$ & - & G & - & \\
\hline $\begin{array}{l}\text { City Hospital } \\
4697 \text { Harrison Street } \\
\text { Bellaire, OH. } 43986\end{array}$ & $\mathbf{N}$ & - & $M$ & - & \\
\hline $\begin{array}{l}\text { Einnigan Institute } \\
\text { Atkinson Square } 11750 \text { Chester } \\
\text { Cincinnati, OH. } 45246\end{array}$ & $Y$ & 2 & $i 1$ & N & . \\
\hline $\begin{array}{l}\text { General Motors Corporation } \\
\text { Fisher Body Division } \\
\text { Elyria, OH. } 44035\end{array}$ & $\mathbf{N}$ & - & $I$ & - & \\
\hline $\begin{array}{l}\text { County of Montgomery } \\
\text { Environmental Services } \\
451 \text { West Third Street } \\
\text { Dayton, OH. } 45402\end{array}$ & $\underline{v}$ & 2 & $G$ & $\mathrm{~N}$ & Yent to atmosphere. \\
\hline $\begin{array}{l}\text { Firegtone Tire \& Rubber co. } \\
1200 \text { Eirestone Par!:way } \\
\text { Akron, OH. } 44317\end{array}$ & $\mathbf{N}$ & - & I & - & \\
\hline $\begin{array}{l}\text { Potters Hedical Center } \\
332 \text { W. 6th Street } \\
\text { E. Liverpool, OH, } 43920 \\
\text {. }\end{array}$ & $Y$ & 2 & $M$ & $\mathrm{~N}$ & $\begin{array}{l}\text { Decay to background } \\
\text { levels. }\end{array}$ \\
\hline
\end{tabular}




\begin{tabular}{|c|c|c|c|c|c|}
\hline \multirow[b]{2}{*}{ LICSNSEE NAME AND ADDRESS } & \multicolumn{2}{|c|}{ SURVEY } & \multirow{2}{*}{ 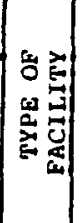 } & \multirow{2}{*}{ 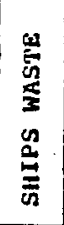 } & \multirow[b]{2}{*}{ COMMENTS } \\
\hline & 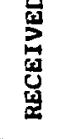 & 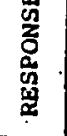 & & & \\
\hline $\begin{array}{l}\text { National Lime \& Stone Company } \\
\text { o. O. Box } 120 \\
\text { Eindlay, OH. } 45840\end{array}$ & $\mathrm{~N}$ & - & I & - & \\
\hline $\begin{array}{l}\text { Kahns \& Company } \\
3241 \text { Soring Grove Avenue } \\
\text { Cincinnati, OH. } 42225\end{array}$ & $\mathbf{N}$ & - & I & - & \\
\hline $\begin{array}{l}\text { Borden Chemical } \\
\text { Drinting Ink Division } \\
630 \text { Glendale-Milford Road } \\
\text { Cincinnati, OH. } 45215\end{array}$ & $Y$ & 2 & I & $n$ & Sealed source used. \\
\hline $\begin{array}{l}\text { Allied Chemical Corporation } \\
\text { Environmental Control Laboratory } \\
3330 \text { S. Third Street } \\
\text { Ironton, OH. } 45638\end{array}$ & $\underline{\mathbf{v}}$ & 2 & I & $\mathrm{N}$ & Return to vendor. \\
\hline $\begin{array}{l}\text { Ferro Corporation } \\
\text { Coatings Division } \\
4150 \text { East } 56 \text { Street } \\
\text { Cleveland, Oh. } 44105\end{array}$ & $Y$ & 2 & I & $\mathbf{N}$ & Return to vendor. \\
\hline $\begin{array}{l}\text { Cyclops Corporation } \\
\text { Empire Detroit Steel Division } \\
3879 \text { Rhodes Avenue } \\
\text { New Boston, OH. } 45662\end{array}$ & N & - & I & - & \\
\hline $\begin{array}{l}\text { Southwest General Hospital } \\
18697 \text { E. Bagley Road } \\
\text { Middleburg Hts. OH. } 44130\end{array}$ & is & - & $\mathrm{M}$ & - & \\
\hline $\begin{array}{l}\text { John D. Tonkovich \& Son Inc. } \\
\text { P. O. Box } 208 \\
\text { Sinadyside, OH. } 43947\end{array}$ & $Y$ & 2 & I & $\mathrm{N}$ & Return to vendor. \\
\hline $\begin{array}{l}\text { Gulf Oil Chemicals Company } \\
\text { P. O. Box } 1000 \\
\text { :Larietta, OH. } 45750\end{array}$ & $Y$ & 2 & $I$ & $\mathrm{~N}$ & Return to vendor. \\
\hline $\begin{array}{l}\text { Kokosing Construction Company Inc. } \\
\text { Construction Denartment } \\
\text { P. O. Box 226, Jaterford Road } \\
\text { Fredericktown, OH. } 43019\end{array}$ & $\underline{v}$ & 2 & I & $\mathrm{N}$ & $\begin{array}{l}\text { Sealeo source used in } \\
\text { soil testing. }\end{array}$ \\
\hline $\begin{array}{l}\text { Resource International Inc. } \\
\text { l30 East Wilson Bridge Road } \\
\text { Northington, OH. } 43229 \\
\end{array}$ & N & - & I & - & \\
\hline
\end{tabular}




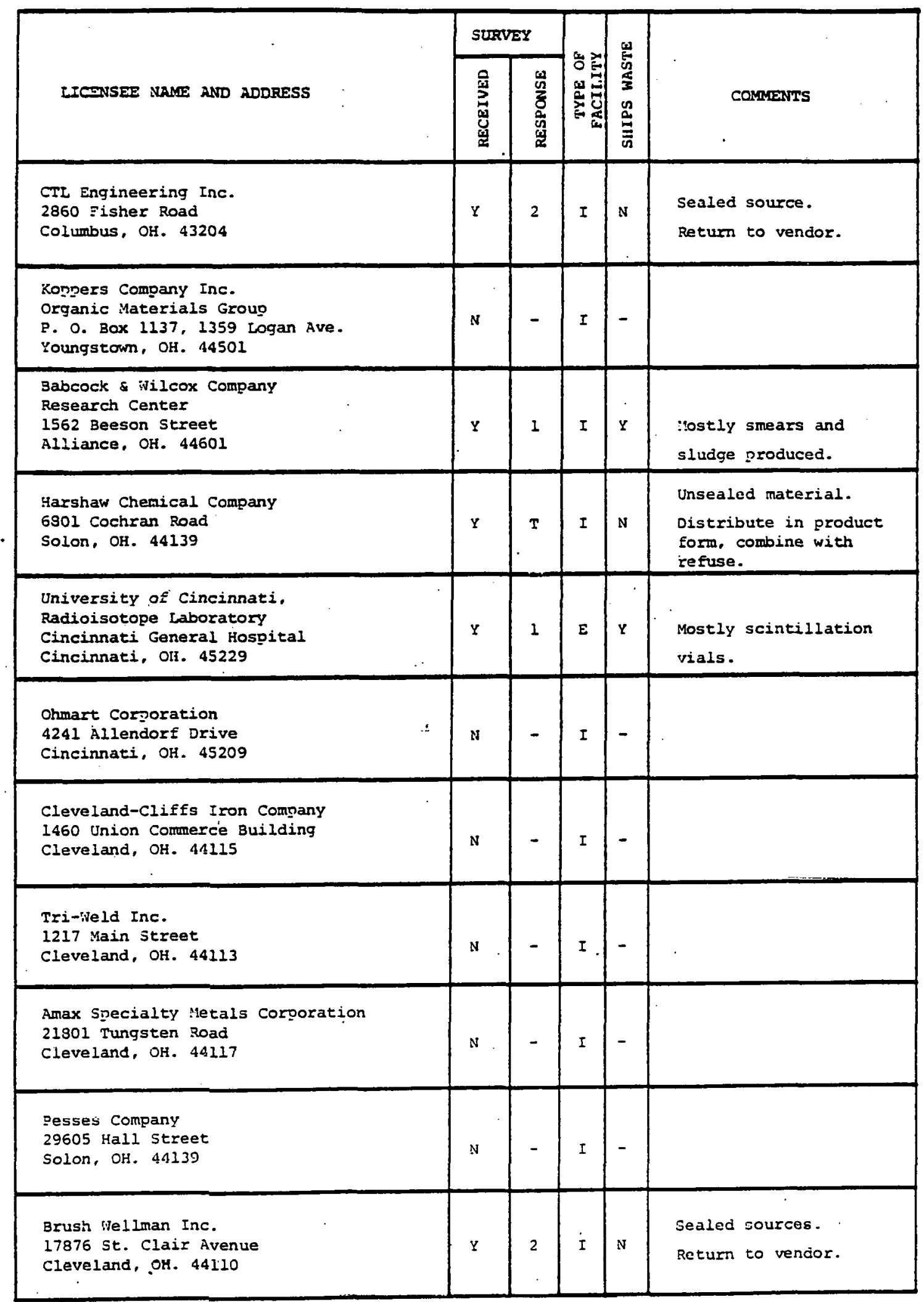




\begin{tabular}{|c|c|c|c|c|c|}
\hline \multirow[b]{2}{*}{ LICENSEE NAME AND ADDRESS } & \multicolumn{2}{|c|}{ SURVEY } & \multirow{2}{*}{ 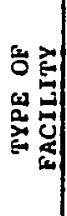 } & \multirow{2}{*}{ 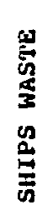 } & \multirow[b]{2}{*}{ COMMENITS } \\
\hline & $\sum_{\substack{3 \\
0}}^{3}$ & 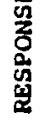 & & & \\
\hline $\begin{array}{l}\text { Advanced Medical Systems Inc. } \\
1020 \text { London Road } \\
\text { Cleveland, OH. } 44110\end{array}$ & $Y$ & 1 & $M$ & $\Psi$ & $\begin{array}{l}\text { iostly dry solids, } \\
\text { irradicated components. }\end{array}$ \\
\hline $\begin{array}{l}\text { Aluchem Inc. } \\
\text { OI Landy Lane } \\
\text { Reading, OH. } 45215\end{array}$ & $\mathbf{N}$ & - & $I$ & - & \\
\hline $\begin{array}{l}\text { Kettering liedical Center } \\
3535 \text { Southern Boulevard } \\
\text { Kettering, OH. } 45429\end{array}$ & 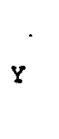 & 2 & $\mathrm{M}$ & $\mathbf{N}$ & $\begin{array}{l}\text { Release to sewer, } \\
\text { combine with refuse, } \\
\text { return to vendor. }\end{array}$ \\
\hline $\begin{array}{l}\text { Imperial Glass Corporation } \\
29 \text { th Street } \\
\text { Bellaire, OH. } 43906\end{array}$ & II & - & I & - & \\
\hline $\begin{array}{l}\text { Kayar Manufacturing Co. } \\
3301 \text { Train Ave. } \\
\text { Cleveland, OH. } 44113\end{array}$ & $\mathbf{N}$ & - & I & - & $\cdot$ \\
\hline $\begin{array}{l}\text { Lancaster Glass Corp. } \\
220 \text { ivest Main Street } \\
\text { Lancaster, OH. } 43130\end{array}$ & $\mathbf{Y}$ & 2 & I & $\mathrm{N}$ & $\begin{array}{l}\text { Distributed in product } \\
\text { form. }\end{array}$ \\
\hline $\begin{array}{l}\text { Vernitron Corporation } \\
\text { Vernitron Piezoelectric Division } \\
232 \text { Forbes Road } \\
\text { Bedford, OH. } 44146\end{array}$ & is & - & I & - & \\
\hline $\begin{array}{l}\text { Victory White Hetal Company } \\
6100 \text { Reland Avenue } \\
\text { Cleveland, OH. } 44127\end{array}$ & $\mathrm{~N}$ & - & I & - & \\
\hline $\begin{array}{l}\text { I. Deutch \& Sons Inc. } \\
311 \text { Baymiller Street } \\
\text { Cincinnati, OH. } 45203\end{array}$ & $\mathbf{N}$ & - & I & - & \\
\hline $\begin{array}{l}\text { Ferro Corporation } \\
\text { One Erieview Dlaza } \\
\text { Cleveland, OH. } 44114\end{array}$ & $\mathbf{Y}$ & 2 & I & $\mathbb{N}$ & $\begin{array}{l}\text { Distribute in procuct } \\
\text { form, return to } \\
\text { vendor. }\end{array}$ \\
\hline $\begin{array}{l}\text { Good Samaritan Hospital } \\
1425 \text { Hest Eairview Avenue } \\
\text { Dayton, OH. } 45406\end{array}$ & $\mathbf{Y}$ & 1 & if & $Y$ & $\begin{array}{l}\text { Mostly dry trash, } \\
\text { solida, irradicated } \\
\text { components shipped. }\end{array}$ \\
\hline
\end{tabular}




\begin{tabular}{|c|c|c|c|c|c|}
\hline \multirow[b]{2}{*}{ LICENSEE NAME AND ADDRESS } & \multicolumn{2}{|c|}{ SURVEY } & \multirow{2}{*}{ 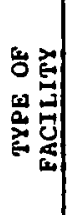 } & \multirow{2}{*}{ 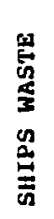 } & \multirow[b]{2}{*}{ COMAENTS } \\
\hline & 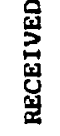 & 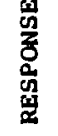 & & & \\
\hline $\begin{array}{l}\text { Babcock \&ilcox } \\
\text { Alliance Research Center } \\
1562 \text { Beeson St. } \\
\text { Alliance, OH. } 44601\end{array}$ & $\mathbf{Y}$ & 1 & I & $\mathbf{Y}$ & Mostly smears and sludge \\
\hline $\begin{array}{l}\text { Battelle Columbus Laboratories } \\
505 \text { King Avenue } \\
\text { Columbus, OH. } 43201\end{array}$ & $y$ & 1 & I & $Y$ & $\begin{array}{l}\text { Dry trash irradicated } \\
\text { components. }\end{array}$ \\
\hline $\begin{array}{l}\text { University of Cincinnati, } \\
\text { Cincinnati General Hosoital } \\
\text { Cincinnati, OH. } 45229\end{array}$ & $\mathbf{Y}$ & 1 & $\mathbf{E}$ & $Y$ & $\begin{array}{l}\text { inostly scintillation } \\
\text { viles shipped. }\end{array}$ \\
\hline $\begin{array}{l}\text { University of Toledo, } \\
\text { Dept. of Physics \& Astronomy } \\
\text { West Bancroft Street } \\
\text { Toledo, OH. } 43606\end{array}$ & $Y$ & $\mathbf{T}$ & E & $Y$ & \\
\hline $\begin{array}{l}\text { RMI Company } \\
\text { Extrusion Plant } \\
\text { P. O. Box } 579 \\
\text { Ashtabula, OH. } 44004\end{array}$ & $\Psi$ & - & I & $Y$ & $\begin{array}{l}\text { Spent rasins, absorbed } \\
\text { liquids, filter sludged } \\
\text { and dry trash. }\end{array}$ \\
\hline $\begin{array}{l}\text { Vistron Corporation } \\
\text { Fort Amenda Road } \\
\text { o. O. BOx } 628 \\
\text { Lima, OH. } 45802\end{array}$ & $Y$ & 2 & I & $\mathbf{N}$ & . \\
\hline $\begin{array}{l}\text { General Electric Company } \\
\text { Lamp Division } \\
\text { Nela Park } \\
\text { Cleveland, OH. } 44112\end{array}$ & $\mathbf{N}$ & - & I & - & \\
\hline $\begin{array}{l}\text { Ohio State University } \\
410 \text { West 10th Avenue } \\
\text { Columbus, OH. } 43210\end{array}$ & $\mathbf{Y}$ & $\mathbf{T}$ & E & $Y$ & Sealed, unsealed. \\
\hline $\begin{array}{l}\text { General Electric Company } \\
\text { Aircraft Engine Group } \\
\text { l Jimson Road } \\
\text { Cincinnati, OH. } 45215\end{array}$ & $\mathrm{~N}$ & - & I & - & \\
\hline $\begin{array}{l}\text { National Aeronautics \& Space } \\
\text { Administration } \\
\text { Lewis Research Center } \\
21000 \text { 3rookpark Road } \\
\text { Cleveland, OH. } 44135\end{array}$ & $Y$ & 1 & $G$ & $Y$ & $\begin{array}{l}\text { Dry solids, trash. } \\
\text { irradicated components. }\end{array}$ \\
\hline $\begin{array}{l}\text { University of Cincinnati } \\
\text { Metallurgical Engineering Department } \\
\text { Cincinnati, OH. } 45221\end{array}$ & $Y$ & 1 & $E$ & $Y$ & Unsealed material. \\
\hline
\end{tabular}




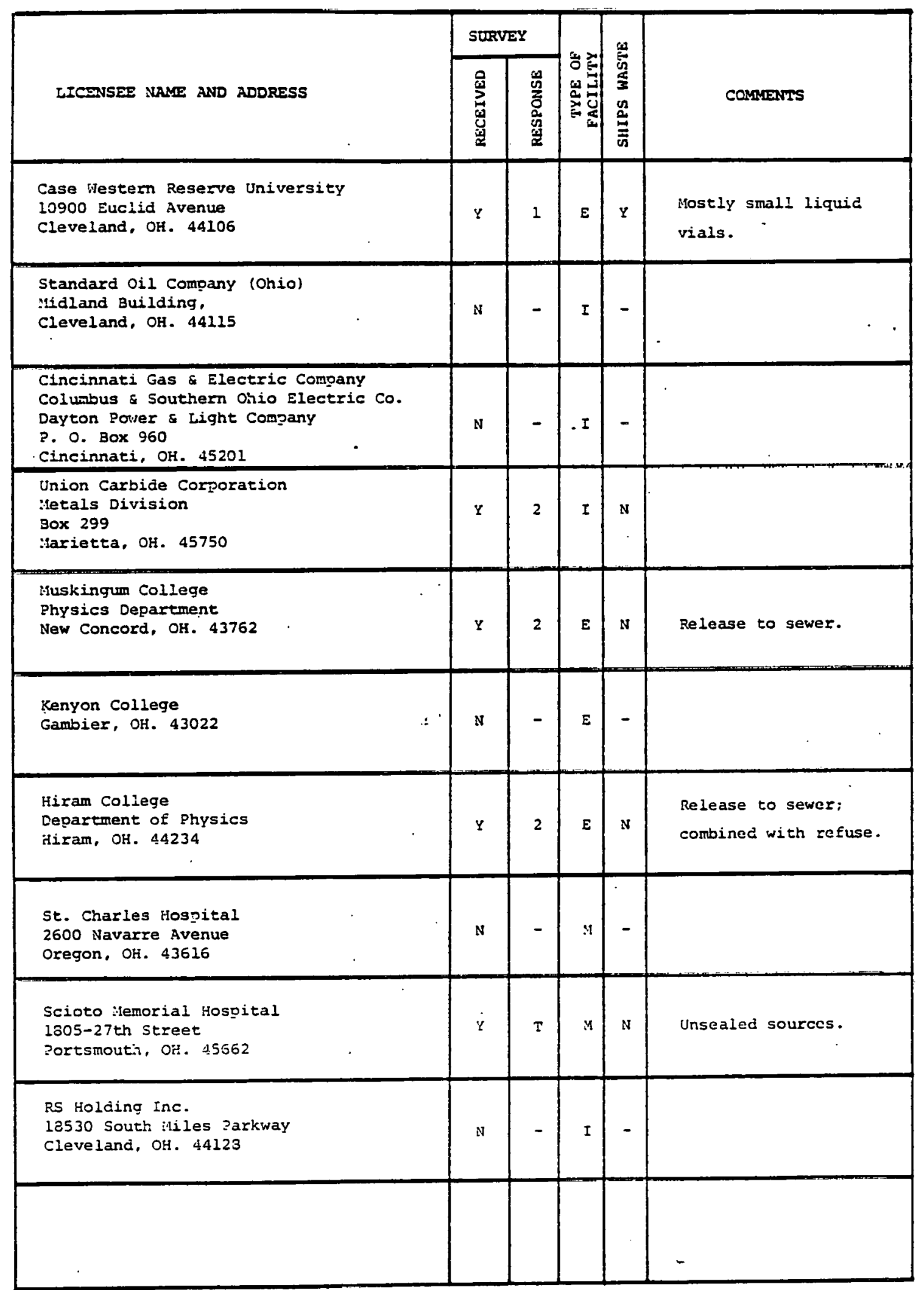


APPENDIX B

OHIO LEGISLATION AND REGULATION

$\therefore$ 


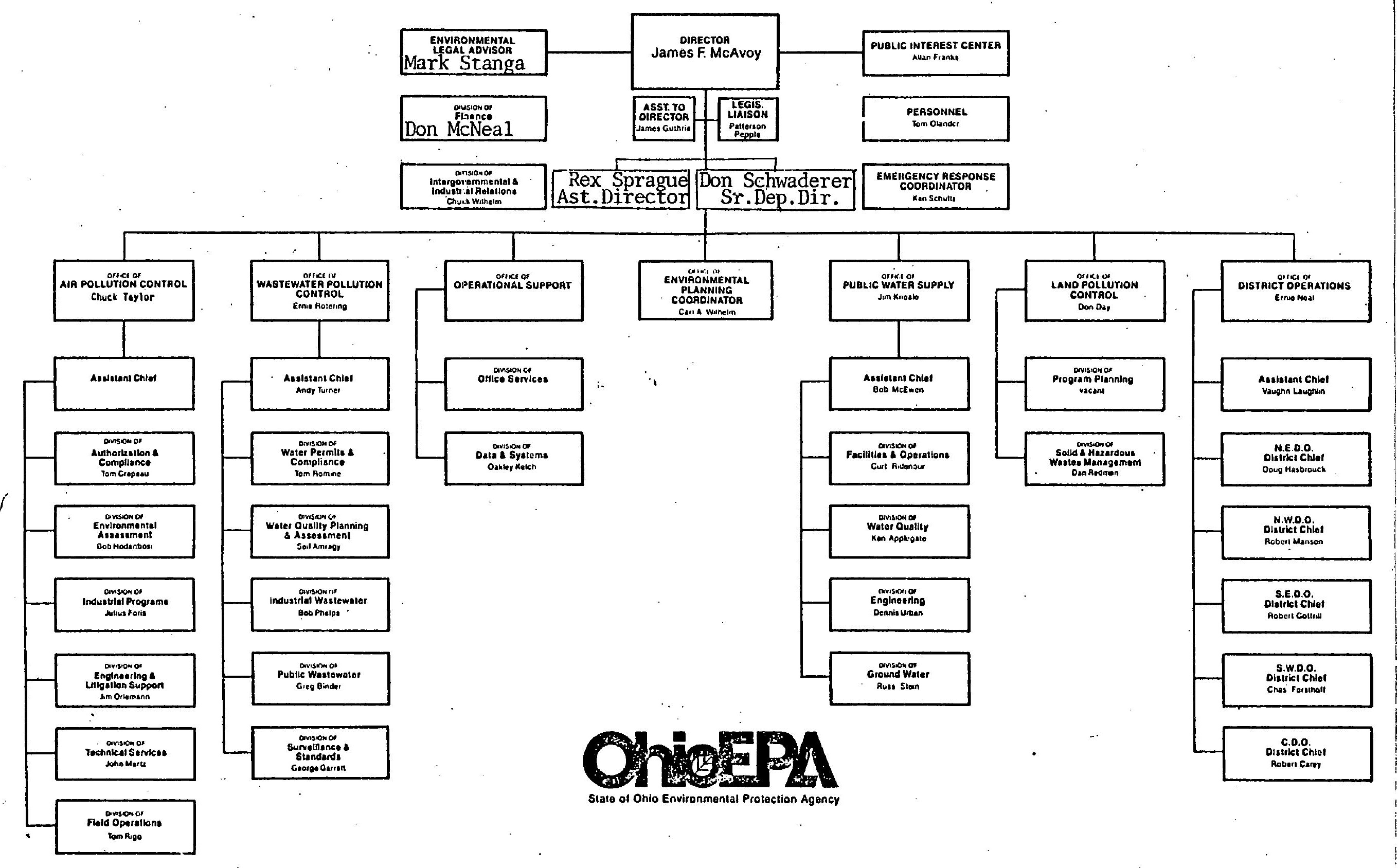




\section{EX OFFICTO VIREERS}

THOMAS D. EARSON, P.E. Secretary of Trasportation 1200 Transportation \& Safety Blds. $787-5574$

EDNAFD G. BIESTER, JR. Attorney Ger:eral

Room 1, Matn Capitol Amex

787-3391

GDOFHET STINGEL, $R$.

Secretary of Correrese

419 South Office Bldg.

787-3003

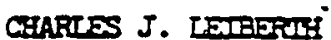

Secretary of Iabor \& Industry

1700 Labor \& Incustry Bldg.

78.7-3157

B. ARNOTD MULRR, MD

Secretary of Health

802 Geelth \& Welfare Bldg.

$787-6436$

GTIFFORD L. JONES

Secretary of Envirormental Resources

gth Floor, Fulton dank Blds.

$787-2814$.

DANDII F. DONN

Comolssioner Permsylvanta. State Pollce

PSP Hdqtrs., 1800 Elmerton Are., kibg. $783-5558$

MS. SUSAN M. SHANAMAN

Chatrman, Public Utility Commssion

I04 inorth Cffice Blds.

$783-3601$
JOIN A. PACEUTA (Proxy)

Drector, Safety Programing \& Analys1s

202 Transportation \& Safety BIdg.

787-7350

RONATO H. SKUBECZ (ProxO)

Deputy Attorney General

Rocm 25 "H", Main Capitol Ammex

$783-1466$

Bustness Consultant

412 South Orflce Bldg.

$783-5700$

CFARTES A. HENRY (Proxy)

State Flre Commissioner

1547 Labor \& Industry Blos.

$787-1325$

WIITTAM C. DEMILEFS (Proxy)

OArector, DIVIsion Jmergency Health Servaces

1031 Health \& Welfare Bdlg.

$787-8741$

IHOMAS M. GERUSKY (Proxy)

Drector, Radiatior: Protection

500 Fulton Bank Bldg.

$787-2480$

MAJ. BPRNARD G. STANATONIS (Proxy)

Burean of Patrol

PSP Haters., 1800 gimerton Ave., Hbg.

$783-5517$

GDORGE C. HOGAN (ProxJ)

Representative of Public Ut1litiy Comntssion 26 illicroft Rd., Feasterville, PA 19047 (215) $238-6960$

\section{APFOTNIED MEMBERS}

GJCRGE MAWFTMNEY

Representing Ceneral Pubilc

R D \#I

Canonsburge, PA 15317

(412) $391-3540$

EDWIN A. ROBB

Fiepresentizg Fire Services

434 Claremont Rd.

Sortngeleld, IA 19064

(215) 543-2908

GDORLE L. GRIFFITH

Representing Maufacturer or Shipper

130 Wall St.

Bethlehen, PA 18018

(215) $867-2487$
ROBDRT T. HINDLE

Representing Common Carrier - Matlack Inc.

Beaver Hill Rd.

Chester Springs, PA 19425

(215) $259-9800$

ROBERTI F. VARNER

Represent1ry highway Safety

19 N. Russell St.

Tork, PA 17402

(717) $755-1506$

GERALD F. HAGERTY

Representing Private Carrier

129 vorman Way

Este, PA 16508

(814) 454-6231 
Mr. James G. Terr11l, Jr. (Chal rman)

4111 Dundee Drive

Murrysville, PA 15668

Tele: $\quad 412-325-1770$

Office: 412-351-5800 Ext. 105

Mr. Fredertck J. Bissert

Technical Assistant-Nuclear

Beaver Valley Power Station

P.O. Box 4

Shippingpurt, PA 15077

Tele: 412-643-5255

Malling Address: 2446 S1lver Oak Place (Home) Pittsburgh, PA 15220

Mr.R. F. G11keson

Chairman of the Board

PhIladelphia Electric Company

2301 Market Street

Philadelphia, PA 19101

Tele: 215-841-4211

Robert C. Good, Jr., Ph.D.

10 Wellesly Road

Swarthmore, PA 19081

Tele: Home: 215-KI3-8766

office: 215-L06-6010

Dr. Alexander Lewis, Jr. (Consultant)

Gulf Oll Foundation

Gulf Building

Danville rarm

Pittsburgh, PA 15230 717-275-4709

Tele: 412-263-5206

Nalling Address: 807 Valley Vlew Rd. P1ttsburgh, PA 15243

Tele: 412-531-1094
Nicl Wald, M.D.

Chairman, Department of Radiation Health

University of Pittsburgh

RC508 Scaife Hall

Pjtesburgh, PA 15261

Tele: 412-647-3495, Ext. 691

Warren Witzig, Ph.D.

Professor and Head

Department of Nuclear Enrineering

The Pennsylvania State Untuersity

Universicy Park, PA 16802

Tele: 814-865-1342 (231 Sackett B1dg. (475)

Theodore Tristan, M.D.

Department of Radiology

Harrisburg Polyclinic Hospital

2601 N. 3rd Street

Harrisburg, PA 17105

Tele: 717-782-4250

Malling Address: 353 N. 28th Street Camp H111, PA 17011

Tele: $717-761-2958$

Secretary of Commerce

Rep. Bob Laughlin

400 South office

Tele: $7-7120$

Secretary of Environmental Resources

Clifford L. Jones 7-2814

Mr. C. J. Sevick

419 Argonne Drive

New Kensington, PA 15068

Tele: 412-335-0818 
MEMBERSHIP OF THE OHIO WATER DEVELOPMENT AUTHORITY

Edwin F. Mulligan

40 Sheridan Rd.

P.0. Box 386

Coshocton, $\mathrm{OH} \quad 43812$

William Amicon

2815 Pickwick Drive

Upper Arlington, $\mathrm{OH}$

43221

Ned Skeldon

2251 Burroughs

Toledo, OH 43614

Philip Zannella

994 West Mill Orive

Highland Heights, $\mathrm{OH} 44143$

Martha C. Moore

501 Oakland Blvd.

Cambridge, $\mathrm{OH}^{\prime} 43725$

James F. McAvoy, Director

Ohio E.P.A.

361 E. Broad Street

Seneca Towers - Room 201

Columbus, $\mathrm{OH} 43215$

Wayne S. Nichols, Director

Ohio Dept, of Energy

30 E. Broad Street - 34th Floor

Columbus, $\mathrm{OH} \quad 43215$

Dr. Robert W. Teater, Director

Ohio. Dept. of Natural Resources

Fountain Square

1952 Belcher Drive

Columbus, $\mathrm{OH} 43224$ 
STATE OF OHIO

MEMORANDUM OF UNDERSTANDING

RESPONSE TO HAZARDOUS MATERIALS INCIDENTS

A. General

1. The Director, Oh10 Disaster Services Agency, pursuant to the author1ty contained in Chapter 5915.02, Oh10 Revised Code, to coordinate the activitles of all agencles for clvil defense and disaster preparedness within the state, has developed this agreement in coordination with agencles concerned. This document addresses the procedures to be followed by the Oh10 D1saster Serv1ces Agency (DSA), the Oh10 Environmental Protect1on Ageacy (BPA), the Stace Fire Marshal (SIM), the Oh10 Department of Highway Safecy/Stace H1ghway Patrol (SHP), the Public Ut111t1es Comansa10a of Oh10 (PUCO), and the Oh10 Department of Transportation (DOT) when responding to lncidents involving hazardous materlals. The EPA enterg 1nto th1s Mamorandur of Understanding pursuant to the Intent of the General Assembly set forth In Section 3745.011 of the Revised Coda and the statutory authorlty provided for in Sactions 3704.03; 3734.02 ; 6109.03; 6109.04 and 6111.03 of the Rev1sed Code. The SEM's office enters lnto this Memorandum of Understanding pursuanc to Chapter 3737 of the Revised Code.

2. Hazardous materials Include Elammable liquids and sollds, compressed gases, corrosive 11qu1de, and other aubstances which may be polsonous, radioactive, oxtd1zing, or explosive.

3. In order to prov1de for fund1ng: for transportation relaced hazardous materiale lncidenta, the roles prescribed in this agreement will establish a basis for applicabilicy of funds. Training provided through auch funding to avallable to all particlpants in emergency ragponse organlzat lons and w1l be conducted accordingly by all agencies.

B. Functional Respons 1b111c1es

1. STATE FIRE MARSHAL

The SFM 1s the responsible State agency for primary coordination of activities of State agencles when a hazardous materlals incident results In fire or explosion or when the potential for fire or explosion is greater than the environmental hazard. During such emergencies, SFM may require support from EPA, DSA and other State agencles, depending upon the severtty of the emergency and agency capab111t1es. The SFM shall be consldered the primary Stace agency for preventing or mitigating the effects of hazardous materials incidents which involve fire or explosion. When in the judgement of the Director of EPA or h1s 
authorlzed representative(s), the exvironmental hazards are greater than the potential for fire or explosion, the EPA shall assume the primary role, retaining close coordination with the SFM and/or local f1re author1ty.

\section{ENVIRONMENTAL PROTECTION AGENCY}

The EPA is particularly concerned with hazardous materlala Incidents whlch involve one or more of the following condltions:

a. Release of toxic fumes or runoff which threatens the public health or safety.

b. The alr, water, or lands of the state could be adversely affected.

c. A public water supply, sewage treatment aystem or water disposal site could be adversely affected.

In the event the hazardoue materials incident does not involve fire or explosion, the potential for fire or explosion, or radioactive materlals, EPA U1Il ageume the State primary role for coordinating activities of State agencles, supported by SEM, DSA and other State agencles as approprlate (Department of Health. Department of Agr1culture, Department of Natural Resources). If the fire or explosion potential is greater than the enviroamental hazarda, as determined by the Director of EPA or h1s authorlzed representative(8), the BPA will assume an advisory role to the SFM unt1I the threat of fire or explosion subsides. BPA w11l support the other agencles when not employed In a primary role and will provide advice, monttoring and coordination of the removal, neutralization and/ or dispoas of hazardous matertale from the lacident a1te.

\section{DISASTER SERVICES AGENCY}

In hazardous materials incidents Involving radioactive materialo, DSA will assume the primary state role for coordinating activitles of the other State agencies. In incidents not involving radioactive matertals, DSA w111 support the SRM and EPA.

\section{Coordination}

1. In all hazardous materlals incidents, the State agency receiving the first notification w11l notify the other state agencles, as described In Section $F$. When notffled, designated representatives of each agency will assess the actual or potentlal hazard for fire or explosion, release of toxic substances, radiation, or any other environmental concern. Coordination shall be made whereby the primary response agencles (SFM, EPA, and DSA) can collectlvely assess the problem and Identify the actions required for lmedlate response.

2. While this document requires notification and exchange of information between responding agencles, actual on-scene State response w11l be at the discretion of the particular agency director or his designated 
representative, based upon the nature of the incident and the type of needs extsting.

\section{Support Agenc1es}

Three State agencles have been identifled as having primary roles in responding to hazardous materials incldents. There are other State agencles wh1ch routinely support these types of operations. The agencles and their roles/capabilitles are 1dentified in this section.

1. The STATE HIGKWAY PATROL sha11 assist with communtcations, area securfty, traffic control, evacuation and emergency rescue as needed, in coordination with local law enforcement agencles, or function as required on State property or highways.

2. The DEPARTMENT OF TRANSPORTATION shall assist with alternate routing and scheduling of traffic and provide additional heavy equipment and communications oupport as aeeded.

3. The PUBLIC UIIIITIES COMISSION shall eatabliah regulations to prevent hazardous materlals transportation incldents and conduct Inspections of vehlcles trapsporting hazardous materlala.

\section{B. Training}

To effectively respond to emergencles 1nvolving hazardous materials so that the environment, health, welfare and property of Ohlo's cltizens are adequately protected, each primary response agency.conducts training of local and State respone personnel in its particular area of concern as follows:

1. STATE FIRE MARSHAL - Fire Aspects of Hazardous Materlalo Incidents (Res1dent and Nonresldent)

2. ENVIRONMRNTA广 PROTECTION AGENCY - Hazardous Mater1ala Sp111 Control (Nonresident Only)

3. DISASTER SERVICES AGENCY - Rad1ological Awareness, Monftoring and Decontamination

F. Not1fication

1. The following State agencles w1ll be 1mmediately notffled of any incident involving hazardous materials. The notiflcation to all agencles listed will be made by the agency recelving the first notification that an incident has occurred. 
Agencies

DISASTER SERVICES AGENCY

ENVIRONMENTAL PROTECTION AGENCY

STATE FIRE MARSHAL

STATE HIGHWAY PATROL
24 Hour Numbers

(614) 889-7150

(800) 282-9378

(614) $864-5510$

(614) $466-3830$ or $466-2660$

2. The following State agencles will be notifled as indicated, as soon as practicable, but not later than the next business day. The notification will be made by the agency recelving the first notification that an Incident has occurred.

DEPARTMENT OR TRANSPORTATION $\quad$ (614) $466-4698$

(If not already notifled for emergency. response purpsose, notify

(DOT) on all incldents in which State highways are invalved)

PUBLIC UTILITIES COMEISSION

(614) 466-3682

(Notify PUCO on all Ipcidents Involving transportation of hazardous mater1818)

3. The following State agencles w1ll be not1fled by EPA as necessary, depending upon the requirement for their participation.

DEPARTMENT OE AGRICULTURE

DEPARTMBNT OF HEALTH

DEPARTMENT OR NATURAL RESOURCES

\section{G. Modification}

Th1 Memorandum uf Understanding ghall iot be modifled except by an agreement In writing signed by the Agencles and Departments 81gnatory below.

ENTERED JNTO THIS DAY OE JUNE, 1980:

FOR THE OHIO ADHHANT GENERAI'S DEPARTMENT, DISASTER SERVICES AGENCY:

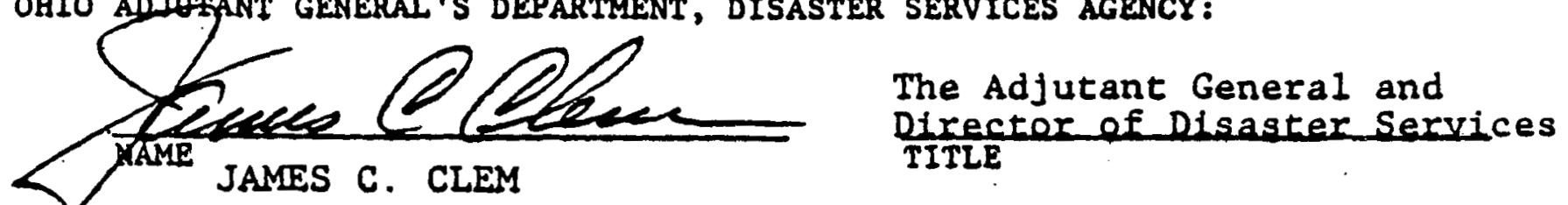

OR THE OHO ENYIRONMENTAL PRETECTION AGENCY:

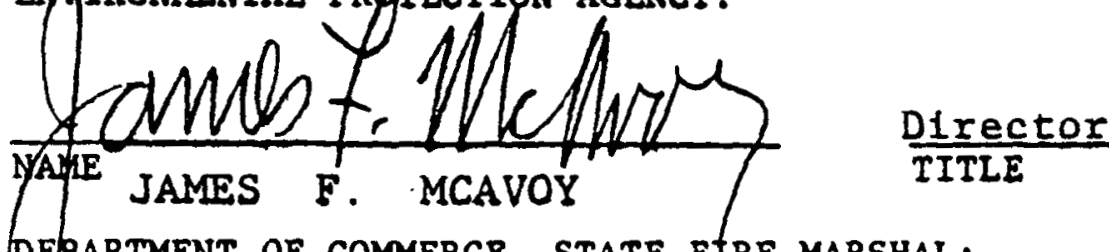

JR THE OHIO DEPARTMENT OF COMMERCE, STATE FIRE MARSHAL:

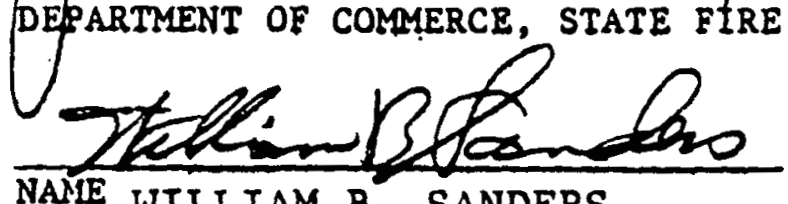

NANIE WILIIAM B. SANDERS
State Fire Marghal TITLE 
FOR THE OHIO PFPARDENT OF HIGHWAY SAFEYY, STATE HIGHWAY PATROL:

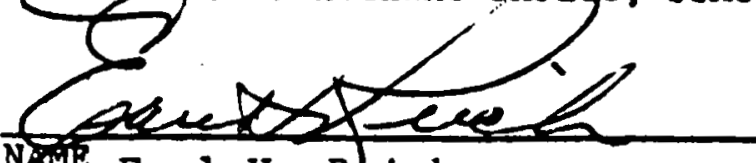

$$
\text { Nate Earl H. Reich }
$$

$\frac{\text { Dipector }}{\text { TITR }}$

FOR THE OHIO DEPARTMENT OF TRANSPORTATION:

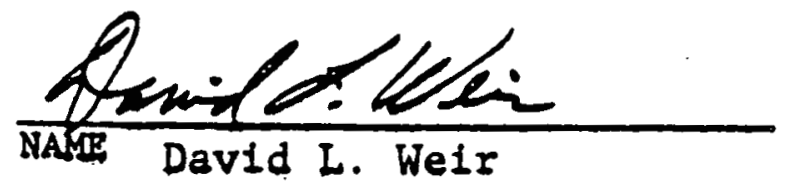

POR THE PUBLIC UTILITIES COMISSION OF OHIg:

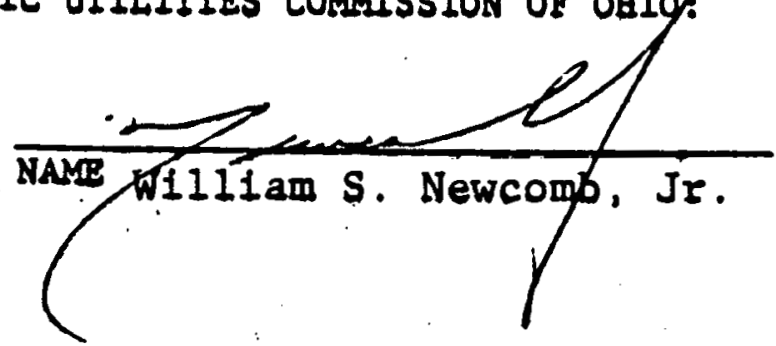

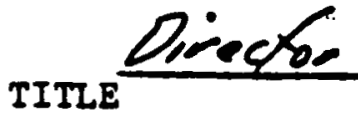

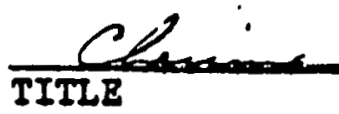




\section{EXECUTIVE ORDER}

WHEREAS, Section 5915.08 of the Ohio Revised Code requires the Governor, in fulfilling his civil defense and disaster services responsibility, to use to the maximum extent practicable, the personnel, services, equipment, supplies and facilities of the State's departments, of rices, agencies and political subdivisions; and

WHEREAS, Section 5915.08 of the Ohio Revised Code also requires officers and personnel of all State departments, offices and agencies to cooperate and extend such services to the Governor and to the State Disaster Services Agency upon request; and

WHEREAS, Section 5915.05 of the Ohio Revised Code requires the Governor to issue and enforce civil defense and disaster services regulations relating to the defense of the state and its people against enemy action or other disaster; and

WHEREAS, certain assignments of disaster related responsibilities have $=$

preuluusly been. madé by Executive-Order; and because current concepts in disaster related procedures necessitate a change in established plans;

NOW THEREPORE, I, JAMES A. RHODES, Governor of the State of Ohio do hereby revoke all previous Executive Orders making assignments of civil defense or. other related responsibilities and services; moreover, pursuant to Chapter 5915 of the Ohio Revised Code, I order into effect the assignment of disaster related functions to the departments, of fices, agencies and bureaus of the State of Ohio as set forth in the attachment hereto.

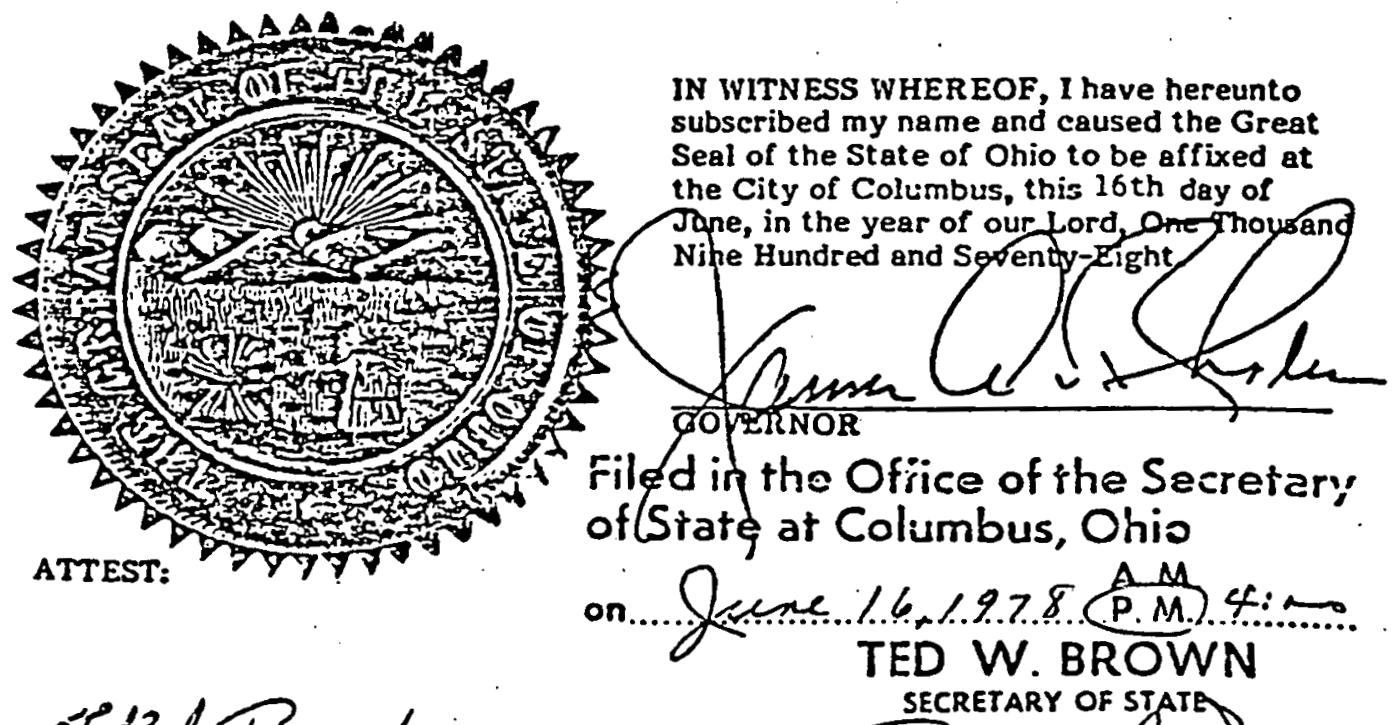


The Hisad of Each Agency:

1. Shall provide for the protection of its personnel, vital records, essential equipment and critical supplies against disaster effects.

2. Shall perform such of its essential normal functions as are not inconsistent with its emergency assignments.

3. Shall designate a staff member to supervise and coordinate disaster planning.

4. Shall provide liaison and staff personnel to the Disaster Services Agency and the Emergency Operations Center as required.during an emergency or disaster situation.

5. Shall provide personnel for temporary assignments during an emergency or disaster situation as requested by the Disaster Services Agency and as directed by the Governor.

6. Shall conduct personnel training programs in civil defense and disaster operations.

7. Shall make its buildings and facilities available for use as fallout shelters, mass care centers, disaster assistance centers and interdepartmental uses as required.

8. Shall assist local governments and other state agencies by providing personnel, equipment and other resources as required.

9. Shall establish lines of emergency interim succession as required by Sec. 161.01 - 161.29 of the Ohio Revised Code.

10. Shall establish economic stabilization controls.

11. Shall cooperate with all federal and state agencies in planning and executing disaster related functions.

12. Shall assist in the implementation of the Emergency Resources Management Program.

13. Shall utilize existing communications resources for warning and disaster operations.

14. Shall provide technical assistance to state and local organizations to assist in the development and coordination of plans for emergency operations. 
The Adjutant General as Director of Disaster Services:

1. Shall be responsible for the coordination of all emergency comnunications during an emergency or disaster situation.

2. Shall coordinate all damage assessment operations in a disaster area.

3. Shall be responsible for alerting and mobilizing all state departments and agencies at the time of an emergency or disaster situation.

4. Shall prepare and maintain, in cooperation with Federal and State departments and agencies, disaster preparedness plans, civil defense plans, community shelter plans, and crisis relocation plans.

5. Shall supervise and coordinate the disaster and civil defense planning and activities of State departments and agencies.

6. Shall establish and maintain an Emergency Operations Center to assist the Governor in coordinating and directing civil defense and disaster services activities.

7. Shall coordinate all emergency disaster and civil defense operations with contiguous states.

8. Shall coordinate the establishment, staffing and administration of the State portion of Disaster Assistance Centers.

9. Shall be responsible for public information programs during an emergency or disaster.

10. Shall coordinate and forward requests for federal disaster assistance under Public Law 93-228 and shall be the state coordinating agency responsible for assisting in the administration of federal disaster assistance programs.

11. Shall monitor nuclear accidents and incidents involving hazardous materials during an emergency or disaster situation to be assisted by the Environmental Protection Agency and the Departments of Health and Transportation.

The Adjutant General as Commander of the Ohio National Guard:

1. Shall coordinate the utilization of the Ohio National Guard with local governments during an emergency or disaster situation.

2. Shall make available the resources, services; and equipment of the Ohio National Guard as required during a disaster or emergency. 
3. Shall provide air and ground transportation assets as required during a disaster or emergency.

4. Shall provide limited emergency potable water to a disaster area in coordination with the monitoring efforts of the Ohio Environmental Protection Agency and the Ohio Department of Health.

The Superintendent of Public Instruction:

1. Shall encourage and promote disaster preparedness planning and training in educational institutions.

2. Shall assist local government in obtaining federal assistance for the restoration of damaged public facilities and property.

3. Shall encourage the cooperation of local school districts in providing personnel and other resources for use in housing, feeding, transporting and evacuating victims following a disaster.

The Administrator of Employment Services:

1. Shall provide representatives in a Disaster Assistance Center to give advice and assistance to disaster affected individuals.

2. Shall provide the resources for the procurement of additional manpower required during a disaster.

3. Shall administer the federal program of Disaster Unemployment Assistance pursuant to Section 407, Public Law 93-288.

4. Shall provide disaster employment information.

The Director of Fnergy:

1. Shall control the emergency distribution and use of all fuels and energy sources during disaster periods.

2. Shall control the emergency distribution and use of alternate and supplementary sources of power during disaster periods.

3. Shall maintain an inventory of all fuels in the State of Ohio which would be available during a period of disaster, and plan for their availability and use at such time.

The Director of Administrative Services:

1. Shall plan for the emergency. use of buildings, lands and facilities during a disaster situation.

2. Shall acquire land, facilities, or other resources from the private sector as required for state operations in a disaster area. 
3. Shall frovide personiel for stä́fing of Disaster Assistance Centers as $r \leq q u i r e d$.

4. Shall assist local government in obtaining federal assistance for the restoration of damaged public facilities and property.

5. Shall provide technical personnel to local government for the inspection, emergency repair or demolition of damaged public structures.

6. Shall conduct training programs in civil defense and disaster operations.

7. Shall maintain an alternate seat of state government as required.

8. Shall provide damage assessment teams to the Disaster Services Agency upon call.

9. Shall establish procedures for the preservation of public records during disasters.

10. Shall establish temporary mobile home sites as required.

11. Sha11 provide and operate a state administrative telephone system in a disaster area.

The Director of the Commission on Aging:

1. Shall provide representatives in a Disaster Assistance Center to give advice and assistance to disaster affected individuals.

2. Shall provide specialized services to the aged in a disaster area to include outreach programs, meals and counseling.

3. Shall coordinate with the local commissions for the use of their facilities for Disaster Assistance Centers, mass feeding centers and other disaster related activities.

4. Shall coordinate with local comnissions to provide qualified senior citizens to assist in disaster related activities.

The Director of Youth Commission:

1. Shall provide 1 and and facilities under its control for use as mass care centers and mobile home sites during an emergency.

2. Shall assist local governments in juvenile counseling and related programs following a disaster. 
The Director of igriculture:

1. Shall plan for the Emergency supply and distribution of food products and livestock feed during disaster periods.

2. Shall be responsible for obtaining additional assistance from U.S. Department of Agriculture through the State Emergency Soard.

3. Shall provide damage assessment teams to the Disaster Services Agency upon call.

The Director of Commerce:

1. Shall provide representatives in a Disaster Assistance Center to give advice and assistance to disaster affected individuals.

2. Shall provide assistance to local building and construction associations in a disaster area.

3. Shall provide assistance to local government in obtaining rights of way to private property.

4. Shall provide, as required, information on the availability of fire fighting equipment on a state wide or area basis.

The Director of Economic and Community Development:

1. Shall maintain an inventory of Ohio industries.

2. Shall promote industrial preparedness and recovery planning.

3. Shall constitute a planning group in a disaster area to:

a. Obtain federal and state financial assistance; and

b. Coordinate local and regional planning agencies in recovery programs.

4. Shall determine the availability of temporary housing in a disaster area and be prepared to administer the Temporary Housing Program pursuant to Section 404, Public Law 93-288.

5. Shall provide representatives in a Disaster Assistance Center to give advice and assistance to disaster affected individuals.

The Director of Environmental Protection:

1. Shall protect public water sources from the effects of chemical contamination.

2. Shall provide damage assessment teams to the Disaster Services. Agency upon call.

3. Shall monitor contamination and pollution during disaster periods. 
4. Shall assist jocal government in obtaining federal assistance for the restoration of damaged public facilities and property.

5. Shall be responsible for the disposal of hazarcious materials following a disaster, including the seiection of disposal sites and disposal procedures.

6. Shall advise local government of selection of debris disposal. sites as it relates to environmental protection.

7. Shall be responsible for the decontamination of public waterways for use as a source of potable water during disaster periods.

The Director of Health:

1. Shall coordinate the County Health Departments for the implementation of programs for emergency health and medical services.

2. Shall be responsible for coordinating all health and medical activities between state and local agencies and agencies of the federal government.

3. Shall seek and administer any health assistance programs which may be available for immediate aid to individuals during a disaster.

4. Shall be responsible for insuring adequate supplies of blood, eye glasses, dentures, hearing aids, other prosthetic devices and therapeutic supplies in coordination with other state, local and volunteer organizations.

5. Shall insure the maintenance and restoration of public health and sanitation standards in a disaster area.

6. Shall be responsible for certifying the safeness of private water supply sources in a disaster area.

7. Shall prescribe methods for protection from the effects of biological contamination.

8. Shall maintain an inventory of hospitals, health care facilities and emergency medical equipment available for use during disaster sițuations.

9. Shall procure emergency medical supplies and equipment during a disaster situation.

10. Shall monitor disaster areas to insure rodent and vector control.

11. Shall provide damage assessment teams to the Disaster Services Agency upon call. 
The Director of inghriay Safety:

1. Shall develop and operate a warning system for alerting the general populace and State departments and agencies in case of energencies.

The Director of Industrial Relations:

1. Shall provide to the Disaster Services Agency a listing of all mines, quarries, oil wells and open pits as required.

The Director of Insurance:

1. Shall provide representatives in a Disaster Assistance Center to give advice and assistance to disaster affected individuals.

2. Shall determine the extent and type of insurance required in a disaster area to meet the prerequisite of Section 314, Public Law 93-288.

The Director of Liquor Control:

1. Shall provide auxiliary law enforcement personnel as required.

2. Shall provide and distribute liquor and alcohol necessary for medical purposes during a disaster.

The Director of Mental Health and Mental Retardation:

1. Shall provide land and facilities under its control for use as mass care centers and mobile home sites during an emergency.

2. Sha11 coordinate the activities necessary to provide the staff, supplies and facilities necessary to treat victims sutfering from disaster related mental disorders with particular emphasis on Section 413, Public Law 93-288.

3. Shall provide representatives in a Disaster Assistance Center to give advice and assistance to disaster affected individuals.

4. Shall provide auxiliary law enforcement personnel as required, when commissioned by local government authority.

The Director of Natural Resources:

1. Shall provide land and facilities under its control for use as mass eare centers and mobile home sites during an emergency.

2. Shall provide damage assessment teams to the Disaster Services Agency as required. 
3. Shall provide information on available water resources within the state.

4. Shall provide access for fire fighting equiprent in forested areas.

5. Shall provide watercraft for rescue and related uperations.

6. Shall develop a plan for the use of privately owned watercraft and dock facilities.

7. Shall assist local government in obtaining federal assistance for the restoration of damaged public facilities and property.

8. Shall coordinate with the U. S. Army Corps of Engineers in assisting local governments in the emergency repair of dikes, levees, channels and drainage facilities.

The Public Utilities Commission:

1. Shall actively encourage emergency and disaster planning by public and private utility and transportation companies.

2. Shall issue guidelines covering the use of utility and transportation resources during an emergency.

3. Shall coordinate the commitment of additional utility and transportation companies during an emergency.

4. Shall coordinate all public and private utilities and transportation resources in a designated disaster area and also serve as the state liaison with federal agencies.

5. Shall provide damage assessment teams to the Disaster Services Agency upon call.

6. Shall provide for the inter-utility exchange of engineers and trained technicians required for emergency operations.

7. Shall enforce Interstate Commerce Commission and U. S. Department of Transportation regulations for shipments of radioactive and other hazardous materials transported within the border of the state.

The Chancellor of the Board of Regents:

1. Shall encourage and promote disaster preparedness planning and training in educational institutions.

2. Shall assist local government in obtaining federal assistance for the restoration of damaged public facilities and property.

3. Shall represent all institutions of higher education in obtaining federal disaster assistance. 
The Director of Public ielfare:

1. Shall coordinate the County Helfare Departments for the implemientation of a comprehensive program of emergency assistance to families following a disaster to include:
a. Child welfare
b. Food stamps
c. Inter-county welfare operations
d. Non-deferable grants
e. Welfare inquiries
f. Medical treatment

2. Shall maintain liaison with private relief organizations and public agencies during the operation of mass care centers.

3. Shall provide representatives in a Disaster Assistance Center to give advice and assistance to disaster affected individuals.

4. Shall assist private relief organizations and/or public agencies during the operation of food and clothing supply and distribution points in disaster areas.

The Director of Rehabilitation and Correction:

1. Shall provide land and facilities under its control for use as mass care centers and mobile home sites during an emergency.

2. Shall provide inmate labor for use in a disaster area.

3. Shall furnish support to correctional activities of local government during periods of disaster.

Thc Administrator of Rehabilitation Services:

1. Shall provide for emergency vocational rehabilitation services in a disaster area.

2. Shall provide representatives in a Disaster Assistance Center to give advice and assistance to disaster affected individuals.

The Tax Comnissioner:

1. Shall provide representatives in a Disaster Assistance Center to give advice and assistance to disaster affected individuals.

2. Shall assist local government in determining tax revenue losses as it pertains to Section 414, Public Law 93-288. 
- Tite Shairmin of the Ohio Turnpike Comission:

1. Shall jevelop traffic control plans for the Onio Turnpite for use in an Einergency or disaster sicuation.

2. Shall provide for the emigency issuance of special use permits for travel on the turnpike during emergencies.

3. Shall provide for the suspension of oversize and overweight regulations for vehicles, mobile homes and trailers during a disaster situation.

The Administrator of Worker's Compensation:

1. Shall provide representatives in a Disaster Assistance Center to give advice and assistance to disaster affected individuals.

The Director of Transportation:

1. Shall activate and operate the State Emergency Highway Traffic Regulation Center and the Emergency Highway Traffic Regulation posts.

2. Shall develop traffic control plans for use in an emergency or disaster situation.

3. Shall provide for the emergency issue of special use permits to authorize specific travel over designated routes during emergency or disaster situations.

4. Shall establish special provisions for the issuance of oversize and overweight permits and suspend any conditions deemed necessary by the Department of Transportation to facilitate the movement of vehicles and mobile homes during an emergency situation.

5. Shall provide damage assessment teams to the Disaster Services Agency upon call.

6. Shall provide technical resources for the inspection, repair, alteration, condemnation and destruction of damaged transportation facilities following a disaster.

7. Shall be responsible for construction and engineering services in a disaster area to include the procurement of equipment and materials from private contractors.

8. Shall assist local government in obtaining federal assistance for the restoration of damaged public facilities and property. 


\section{Nuclear Wiste In Onio \\ A Status Report: March 1930}

Harold W. Koin

Introduction: Like every state in the union Ohio generates nuclear waste. The amount is not excessive, about three percent of the U.S. total which ranks Ohio fourteenth in the nation. Waste is generated not only by power reactors and fuel processing plants but also from research institutions, defense related activities, industrial sources and especialiy medical facilities.

Recent national actions have precipitated.a near crisis in low-level waste management. In October, 1979, Governors Ray of Washington and List of Nevada closed their low-level waste sites leaving only the Barnwell site in South Carolina open. Governor Riley of south Carolina has announced his intention of not only of limiting the amount of waste shipped to Barnwell, but also of reducing each month the amount of low-level waste which will be accepted there.

Policy statement: Nuclear energy is an area of controversy in some circles. The Ohio E.P.A. does not assume an advocacy position vis-a-vis nuclear energy. Nuclear energy is a fact of present-day life. The function of the Ohio E.P.A. is to see that nuclear activities are carried out in an environmentally acceptable manner.

In 1978, the office of Waste Isolation, then in Oak Ridge, Tennessee, contacted thirty-six state governors concerning research effects aimed towards locating a high-level waste repository in their states. Governor Rhodes directed Ohio DOE director Ryan to inform U.S. DOE that ohio was not to be considered as a candidate for a high-level nuclear waste repository. The Governor cited the congestion in transportation and population in the candidate area (the Salina formation underlying northeast ohio) as well as the non-arid character of the state. We support the Governor's viewpoint, and believe that for at least the first two high-level waste repositories more suitable sites would be available in the arid western U.S. Furthermore, we do not believe that extended, sophisticated and expensive studies as proposed by USDOE are necessary to belabor this point. Such studies help postpone the implementation of a solution.

The situation concerning low-level radioactive waste is considerably different. Low-level waste repositories do not present anything like the problems that a high-level waste repository does. Hence ohio feels a certain responsibility for caring for its lowlevel radwaste. We support the concept of a regional (North Centrail) low-level waste repository and, given a suitable siting study and appropriate tradeoffs would consider the siting of such 
a repository in Ohio.

As a matter of record, there are already two such repositories in the state.

Ohio's Nuclear waste: The following two diagrams show the amounts and sources of low-level radioactive waste for the United States and for ohio. Unfortunately this study does not identify industrial sources; these have been calculated by difierence. An update of this study which will have a better estimate of industrial waste is expected shortly. The principal nuclear waste generators are,briefly described in the following paragraphs.

Davis-Besse Nuclear Power Plant. The 910 megawatt lelectrical) pressurized water reactor at Port Clinton is Ohio's only operating nuclear power reactor. During 1978 , about 340 cubic meters*, of low-level waste containing about 3.3 curies of activity (mostly $58 \mathrm{Co}, 54 \mathrm{Mn}$, and $60 \mathrm{Co}$ ) were shipped offsite. One truck shipment went to sheffield Illinois, the other nineteen shipments went to Barnwell, South Carolina. In 1979, all thirteen truck shipments went to Barnwell, carrying about 260 cubic meters containing about three curies of activity. If Davis-Besse were operated more nearly at capacity, the total amount of waste might be greater. Larger waste shipments should be anticipated for 1980 inasmuch as a refueling is scheduled for this spring and refuelings generate more waste. DavisBesse is unique inasmuch it is the only ohio facility which generates high-level waste. About 400 people are employed at the Davis-Besse facility.

Portsmouth Gaseous Diffusion Plant. This plant has operated since 1954 separating uranium isotopes by the gaseous diffusion process. An expansion of the plant to include a centrifuge facility has been planned for the future. During 1979, Portsmouth generated 7600 cubic feet of radioactive waste containing 1.4 curies of radioactivity, mostly uranium and radium. This waste is buried on site. Portsmouth employs about 3500 people.

National Lead Co, Fernald Ohio. National Lead is a "feed materials plant", making fuel elements for government reactors since 1951. In 1979, 56,712 cubic feet of radioactive waste containing 49.169 curies of radioactivity, mostly uranium, thorium, radium 226 and radium 228 were generated. This material has been buried on site in clay-lined and (more récently) rubberlined pits. National Lead employs 538 people.

Accuray (Formerly Industrial Nucleonics) Columbus, Ohio. Accuray has been making thickness gauges since 1950. About twice a year a shipment of three to four 30 gallon drums con- : taining from 100 to 300 curies each is sent to Barnwell, South: Carolina. These are sealed sources of isotopes such as 137 Caesium,

* A cubic meter is slightly greater than a cubic yard, or is about 30 cubic feet. 


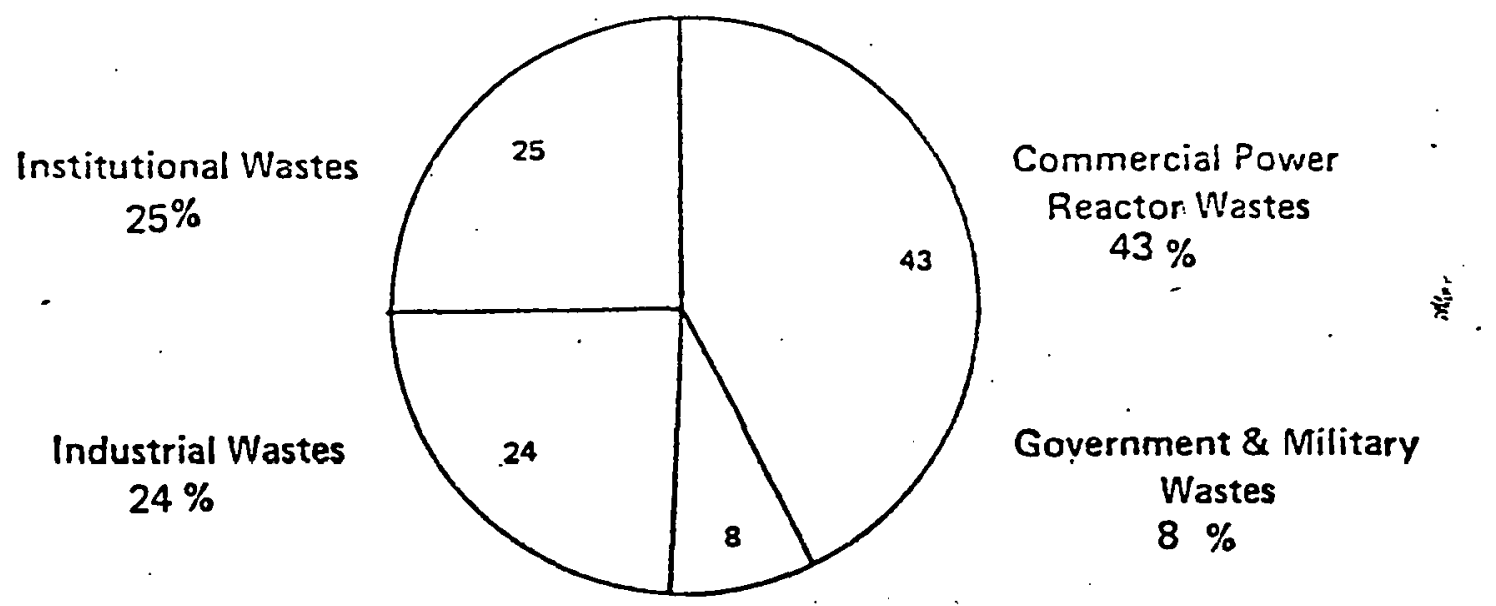

Total Low-Level Radioactive Waste Generated

(Percentages by Sources)

Commercial Power Reactor Wastes $(a, b, c, d)$

Waste Form

Spent resins, filter sludges, and evaporator bottoms

Dry compressible waste and contaminated equipment

Irradiated components

Total

$$
\underline{m^{3} / y r} \quad \therefore \quad C i / y r
$$

17.116

16,653

2,723

1,794

360,515

35,563

404,554

Institutional Wastes (Medical Facilities \& Universities)(e)

Waste Form
Biological
Scintillation Vials
Solidified and
Alsorbed Liquids
Dry Trash

Total $m^{3 / y r}$
1,803
9,223

1,461

8,761

21.248
Ci/yr.

209

1,081

171

1,026
(No. of Installations 66

Typical Radionuclides

${ }^{51} \mathrm{Cr}$

$54 \mathrm{Mn}$

$59 \mathrm{Fe}$

$58 \mathrm{Co}$

${ }^{60} \mathrm{Co}$

$65 \mathrm{Zn}$

${ }^{134} \mathrm{Cs}$

${ }^{136} \mathrm{Cs}$

$137 \mathrm{Cs}$

$140 \mathrm{Ba}$

$141 \mathrm{Ce}$

(No. of Installations 2,390 ')

Typical Radionuclides and \% of Total

\begin{tabular}{|c|c|c|c|}
\hline${ }^{3} \mathrm{H}$ & $29.1 \%$ & $67 \mathrm{Ga}$ & $0.1 \%$ \\
\hline${ }^{14} \mathrm{C}$ & $8.9 \%$ & $T c^{99 m}$ & $30.9 \%$ \\
\hline $32 p$ & $5.3 \%$ & 1251 & $3.5 \%$ \\
\hline $35 \mathrm{~S}$ & $2.0 \%$ & 1311 & $5.9 \%$ \\
\hline${ }^{1} \mathrm{Cr}$ & $1.6 \%$ & Misc. & $12.7 \%$ \\
\hline
\end{tabular}




\section{UNITED STATES}

industrial Wastes ${ }^{(h)}$

(No. of Licensees N/A )

$\underline{\mathrm{m}^{3 / y r}} \quad \underline{\mathrm{Ci} / \mathrm{yr}} \quad \underline{\text { Typical Radionuclides }}$

$\begin{array}{lll}\text { Estimated State Total } \quad 20,397 & 473,579 & \text { N/A }\end{array}$

Government \& Military Wastes (Buried at Commercial Sites) (i)

(No. of Installations 21 )

\begin{tabular}{|c|c|c|c|}
\hline Waste Classification & $m^{3 / y r}$ & $\mathrm{Ci} / \mathrm{yr}$ & Typical Radionuclides \\
\hline Biological Wastes & 11 & $N / A$ & N/A \\
\hline Dry Solids & 6,514 & $N / A$ & N/A \\
\hline Solid Sludge : & 25 & N/A & N/A \\
\hline Not Classified & 22 & N/A & N/A \\
\hline
\end{tabular}

$\begin{array}{lll}\text { Total } & 6,572 & 5,380\end{array}$

Total Volume and Activity Generated ${ }^{(a)}$

a. These are based on USNRC records for 1978 .

b. An NUS study for the U.S. Office of Nuclear Waste Isolation (Report No. ONWI-20 NUS.3314) is ihe basis for these data.

c. These data are bised both on USNAC records for 1978 and on NUS Report No. ONWI-20 NUS-3314.

d. These data were based on communication with the reactor plant operator.

e. These data were based on a draft of the update of the USNRC Institurional Radioactive Wastes Report, No. NUREG/CR-0028.

f. These data were based on a ratio: the number of industrial NRC licenses by state to the total non-agreement state industrial NRC licenses.

9. The basis for these data is the ratio of the state population to the total U.S. population.

h. The basis for the total United States volume and curie content was the difference between all other waste and the total amount buried.

i. The basis for this information is the USDOE Solid Waste Information Management SYstems Report for FY 1978. 


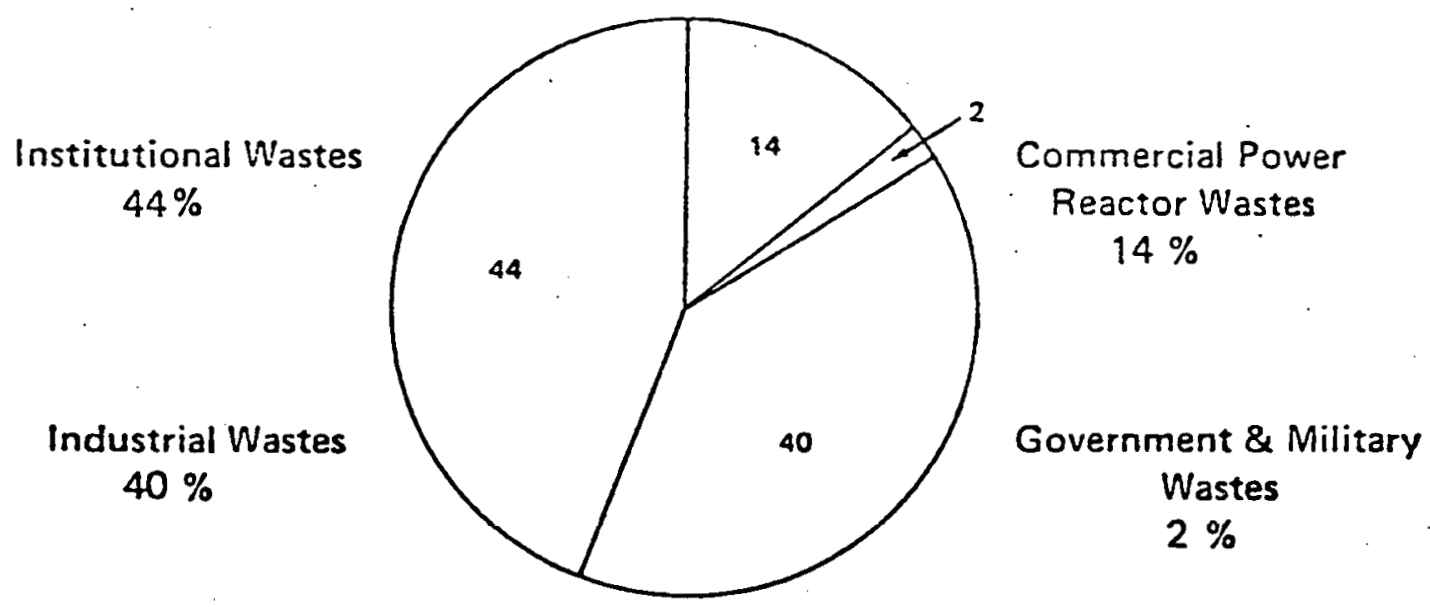

Total Low-Level Radioactive Waste Generated Within the State

(Percentages by Source)

Commercial Power Reactor Wastes (a)

Waste Form
$\begin{gathered}\text { Spent resins, filter } \\ \text { sludges, and evap- } \\ \text { orator bottoms }\end{gathered}$
Dry compressible
waste and contam-
inated equipment

Irradiated components

Total

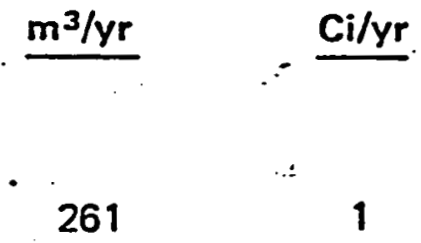

49

0

310
(No. of Installations 1

Typical Radionuclides

${ }^{51} \mathrm{Cr}$

$54 \mathrm{Mn}$

$59 \mathrm{Fe}$

$58 \mathrm{Co}$

${ }^{60} \mathrm{Co}$

$65 \mathrm{Zn}$

${ }^{134} \mathrm{Cs}$

${ }^{136} \mathrm{Cs}$

$137 \mathrm{Cs}$

$140 \mathrm{Ba}$

${ }^{141} \mathrm{Ce}$

Institutional Wastes (Medical Facilities \& Universities) (e)

(No. of Installations 91

Waste Form

Biological

Scintillation Vials

Solidified and

Alusurbed Liquids

Dry Trash

$\begin{array}{rr}\frac{m^{3} / y r}{79} & \text { Ci/yr } \\ 408 & 9 \\ & 46 \\ 64 & 7 \\ 387 & 44\end{array}$

938
Typical Radionuclides

$$
\begin{array}{ll}
{ }^{3 \mathrm{H}} & { }^{67} \mathrm{Ga} \\
{ }^{14} \mathrm{C} & \mathrm{Tc} \mathrm{C}^{99 m} \\
{ }^{32 \mathrm{P}} & 1251 \\
{ }^{35} \mathrm{~S} & 1311 \\
{ }^{51} \mathrm{Cr} &
\end{array}
$$


Industrial Wastes (f)

(No. of Licensees 313 )

Estimated State Total $\frac{\mathrm{m}^{3 / y r}}{844} \quad \frac{\mathrm{Ci} / \mathrm{yr}}{\mathrm{N} / \mathrm{A}} \quad \frac{\text { Typical Radionuclides }}{\mathrm{N} / \mathrm{A}}$

Government \& Military Wastes (Buried at Commercial Sites)(i)

(No. of Installations 1 )

Waste Classification $\quad \underline{\mathrm{m}^{3} / \mathrm{yr}} \quad \underline{\mathrm{Ci} / \mathrm{yr}} \quad \underline{\text { Typical Radionuclides }}$

Biological Wastes

Dry Solids

42

4

N/A

Solid Sludge

Not Classified

Total

\section{Total Volume Generated Within State}

$$
m^{3} / y r \underline{2,134}
$$

a. These are based on USNAC records for 1978.

b. An NUS study for the U.S. Office of Nuclear Waste Isolation (Peport No. ONWI-20 NUS.3314l is the basis for these data.

c. These data are based both on USNRC records for 1978 and on NUS Report No. ONW1-20 NUS-3314.

d. These data were based on communication with the reactor plant operator.

e. These data were based on a draft of the update of the USNRC institutional Radioactive Wastes Report, No. NUREG/CR-0028.

f. These data were based on a ratio: the number of industrial NRC licenses by state to the total non-agreement state industrial NRC licenses.

9. The basis for these data is the ratio of the state population to the total U.S. population.

h. The basis for the total United States volume and curie content was the difference between all other waste and the total amount buried.

i. The basis for this information is the USDOE Solid Waste Information Management Systerns Report for FY 1978. 
60 Cobalt, 90 Strontium or 85 ärygton, and are generally heavily shielded with concrete. Accuray employs about 1500 people.

Ohmart Industries, Cincinnati, Ohio. Onnart has also been making thickness gauges since 1957. Last year they shipped six 55 galion drums to Barnwell containing about fifty curies of $C s$ 137. Most of their sources are returned to the producer for recycle, or are recycled in the plant. ohmart employs 130 people.

Institutional wastes: One further source of ohio's lowlevel radioactive waste comes from its 91 medical facilities and universities: Most of this material, scintillation vials and dry trash, could be safely incinerated, but at present there are no installations in the U.S. Which can process commercial waste this way. (It is interesting to note that low-level radwaste can be incinerated at Mound Laboratories, but this is not commercial waste). There are also six V.A. Hospitals in Ohio who are authorized to incinerate their low-level waste and who indeed do so.

Condensed History of Low-level Waste Disposal: The following table shows the low-level waste burial sites in the contiguous United states. The DOE sites were initiated during the war and handle exclusively DOE wastes. Some high-level waste is also stored at these sites. The first commercial site to open was the Beatty, Nevada site (1962), followed by West Valley, N.Y. (1963) Morehead, Kentucky (1963), Richland, Washington (1965), Sheffield, Illinois (1967) and Barnwell, South Carolina, (1971).

Three of these sites are now closed. West Valley was closed in 1975 after experiencing difficulties with water in the trenches. The land and site are presently owned by the state of New York. At present USDOE is encouraging re-opening of the site, but there are serious difficulties with both the problem of the neutralized high-level reprocessing waste sludge on the same site, the suit between the state of New York and the Federal Government, and the politics generated by this situation.

The sheffield facility ran out of available space in early 1978. The operators (Nuclear Engineering Co.) had applied for a license to expand the facility but this had not been acted upon by last year. Accordingly NECO, finding the operation unprofitable, has withdrawn their license application.

The Morehead (Maxey Flats) facility began experiencing water management difficulties around the middle of the last decade and finaliy at the end of 1977, the state of Kentucky bought out the operator (for $\$ 2 \mathrm{million}$ ) and is presently operating the site. Although there is still burial space available at Maxey Flats, the state of Kentucky has placed a loc per pound tax on all waste going to this facility, thus pricing it out of the market. It has remained essentially unused for the last two years. 
Survey of Existing Low-Level Waste Disposal Facilities

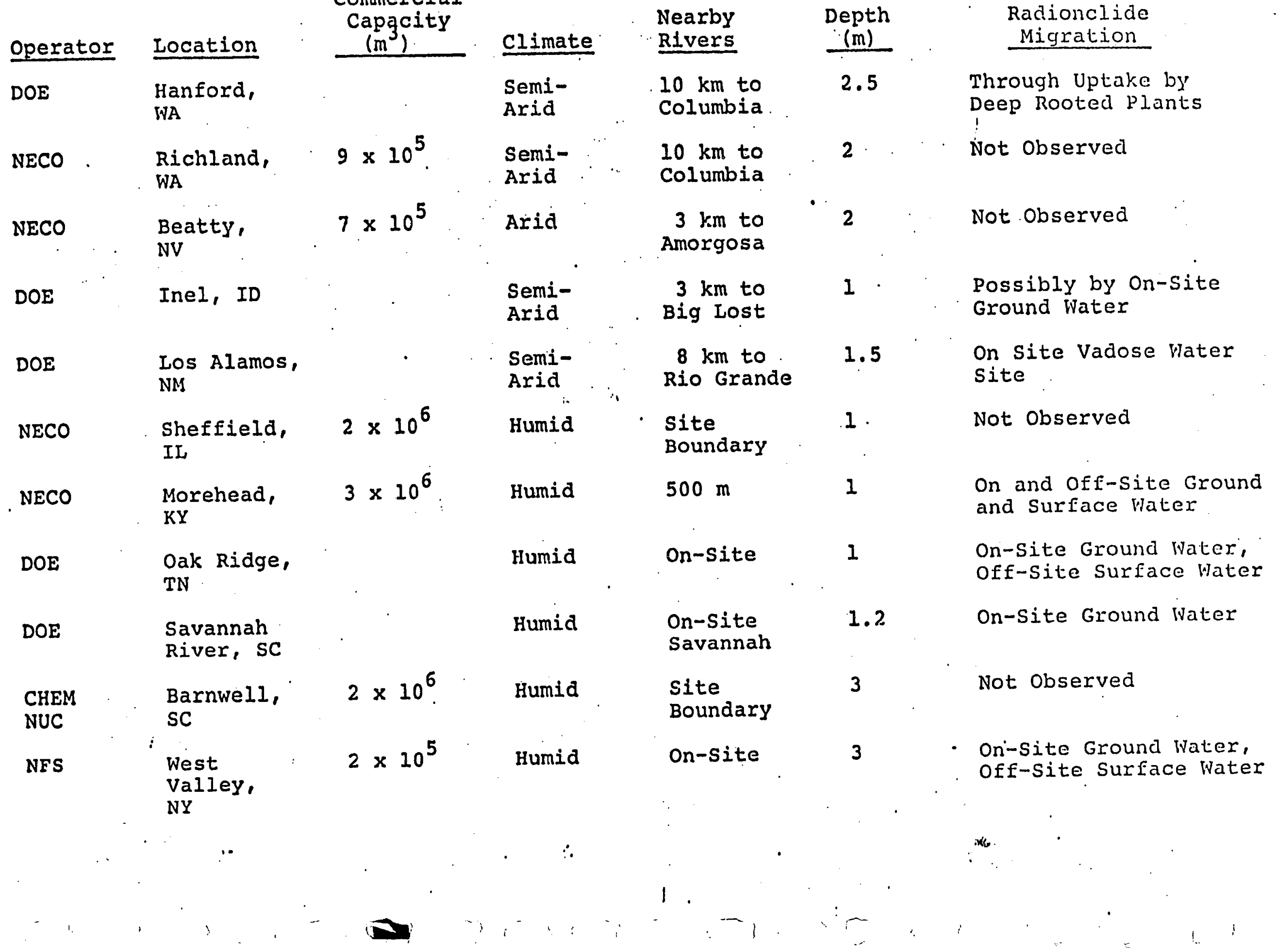


During actober of 1979, both the Beatty, lievadi site and the Richland iasnington site were clcsed by their respective goivinors. The reasons given were slovenly pachaging of the vaste (several containers were found to be leaking). This created a considerable pressure upon radivaste generators and also upon the Barnwell site. The sites were reopened in November but the governors involved served notice upon the United States in general and the nuclear industry in particular; the status quo cannot continue. New sites will have to be found.

Apparently enough pressure was generated on the executive branch to result in an executive order on Febnary 12, 1980, creating a State Planning Council on Radioactive waste Managenent as had been recomnended last year by the Inter-Agency Review Group report (IRG). Part of the text of this announcement follows:

By the authority vested in me as President by the Constitution and laws of the United States of America, and in order to create, in accordance with the provisions of the Federal Advisory Committee Act, as amended (5 U.S.C. App. I), an advisory comittee on radioactive waste management, it is hereby ordered as follows:

1-1. Establishment

1-101. There is established the State Planning Council on Radioactive Maste Management.<smiles>C=[V]</smiles>

1-102. The council shall be composed of eighteen members as follows:

(a) Fourteen members designated by the President as follows:

(1) Eight Governors of the various states.

(2) Five State and local elected government officials other than governors.

(3) One tribal government representative.

(b) The heads of the following Executive agencies:

(1) Department of the Interior.

(2) Department of Transportation.

(3) Department of Energy.

(4) Envirormental Protection Agency.

The members appointed by the President are:

Richard Riley, Chaiman, Governor of South Carolina Paul Hess, Vice Chairman, State Senator of Kansas

John Evans, Governor of Idaho Dixie Ifee Ray, Governor of Washington

Robert List, Governor of Nevada Bruce King, Governor of New Mexico Harry Hughes, Governor of Maryland John Dalton, Governor of Virginia 
Ella Grasso, Governor of Connecticut

Mary Louise Simons, Chairman, Dane County Board of Commissioners

(ivisconsin)

Gordon Voss, State Representative Minnesota

Ernest viorial, Mayor of New Orleans

Stanley Fink, Assemblyman, New York

Peter HicDonnell, Chairman, Navaho Nation

There have also been a, series of meetings initiated late last year by the National Governors Conference. The iNorth Central Regional meeting was held in East Lansing, Michigan and a meeting of governors was held in February in Phoenix. Another regional meeting is scheduled for March 27, 1980 in East Lansing.

Although the President's council is expected to deal principally with the high-level waste problem and The Governor's Conference was formed to deal principally with low-level waste, interaction between the two groups is inevitable. Low-level and high-level waste present the same institutional and political problems. This is indeed unfortunate since low-level waste would be easily dealt with given a reasonable site selection and management program coupled with a vigorous promotion of incineration (of very lowlevel, i.e. hospital and institutional waste). The same can scarcely be said of the high-level problem.

A more complete description of this waste disposal problem is given in the appendix. This material is abstracted from a draft report prepared for the Ohio Department of Energy. 


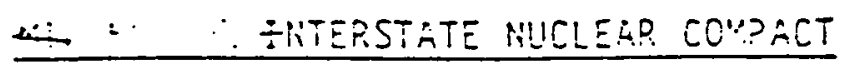

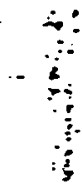

\section{TABLE OF CORTENTS}

ARTICLE

ARTICLE

ARTICLE

ARTICLE

ARTICLE

ARTICLE

ARTICLE

ARTICLE

ARTICLE

ARTICLE
I Policy and Purpose ................ I 1

II Definition of Terms. ............. 2

III The Board. . . . . . . . . . . . . 4

IV Finances.................. 7

v Advisory Comittees. . . . . . ..... 8

VI Powers ................... 9

VII Supplementary Agreements . . . . . . . . . . 12

VIII Other Law's and Regulations . . . . . . . . . 14

IX Eligible Parties Entry Into and Withdrawal .... 15

X Severability and Gonstruction. . . . . . . 16

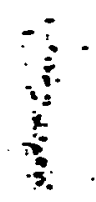




\section{A DRAET COMPACT}

$\therefore-\because$ INTERSTATE RUCLEAR COMAACT

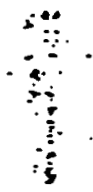

(1) The $\because=\div$

Interstate Nuclear Compect is hereby enceted into law by the State of as a party along with the other States joining therein in accordance with the terms of the compact.

(2) The compact shall become effective when it has been enacted into law by the legislatures of at least signatory States, and has been consented to by the Congress of the United States as provided in Article IX of the Compact.

\section{ARTICLE I}

\section{POLICỸ AND PURPOSE}

The party States recognize that the proper employment of scientific and technological discoveries and advances in nuclear and related fields, and the direct and collateral application and adaptation of processes and techniques developed in connection therewith, properly correlated with the other resources of the region, can assist substantially in the industrial

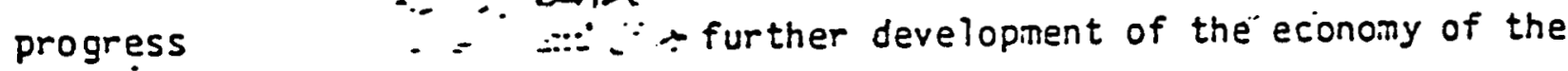
règion. They also recognize that optimum benefit from nuclear and related. sientific or technological resources, facilities and skills requires systematic encouragement, guidance, assistance and promotion from the party States on a cooperative basis. It is further recognized by the 
party States that a regional concept for the safe handing, transport, treatiant and storige or dispasal of lon-level radioactive waste is riscsssary to provide for long-term menagenent of tine waste to protact the ppopiation and environmant and to assist in the orderly economic : development of the party states. It is the purpose of this compact to promote interstate conity, to remove causes of present and future controversies and to provide the instrument and framework for a cooperative effort relating to such low-level radioactive waste concerns.

\section{ARTICLE II}

\section{DEFINITION OF TERMS}

As used in this Compact:

(a) The term "Board" shall mean the ..- Interstate Nuclear Compact Board as created by Article III of this Compact.

(b) The term "Disposal" shall mean the placement or distribution of low-level radioactive waste in its final placement medium.

(c) The term "Extended Care" shall mean those procedures instituted at a disposal site to protect man and his environment after said disposal site has reached the end of its useful life.

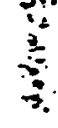


(d) The term "facility" shall mian the structures, equipment or devices re? ated to the treztment, storage, transportation or disposal of loh-ievel radioactive wastes.

(e) The term "Generator" shall mean any person or concern, wito in the course of their activity, produce waste containing radioactive matter.

(f) The term "Low-Level Radioactive Waste" shall mean waste containing radioactive nuclides emitting primarily Beta and/or Gamma radiation, and which is not spent fuel or high level waste and containing less than ten.nanocuries per gram of any transuranic elements or as. otherwise defined in 10 CFR 61, "Disposal of Low-Level Radioactive Waste and Low-Activity Bulk Solid Haste."

(g) The term "Radiation" shall mean the enercy in the form of waves or particles emitted from a nuclide.

(h) The term "Site" shall mean all property, real or personal, considered for or dedicated to the treatment, storage, or disposal of low-level radioactive waste.

(i) The term "State" or "States" shall mean a State or States of the United States and more specifically that State, or those States that are a pairty to this Compact.

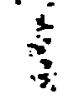

(j) The term "Storage" shall mean the containment of low-level radioactive waste prior to treatment or disposal. 
(k) The term "Treatment" shall wean the physical processing of lon-level rafiosctive naste primerily for volunie reduction purposes.

(1) Tine term "Transport" shall mean the movement of radioactive vaste from one point to another by means of a conom carrier.

(m) The term "Transuranic" shall mean all elements above Uranium in the Periodic Table and including Uranium-233.

\section{ARTICLE III}

THE BOARD

(a) There is hereby created an agency of the party States to be known as the ":. Interstate Nuclear Board" (hereinafter called the Board). The Board shall be composed of one member from each party State designated or appointed in accordance with the laws of the State which he represents, and each such member shall serve and be subject to removal in accordance with such laws. Any member of the Board may provide for the discharge of $h$ is duties and the performance of $h$ is functions (either for the duration of his membership or for any lesser period of time) by a deputy or assistant, if the laws of his State make specific provisions therefor. The Federal Government may be represented without vote if provision is made by Federal law for such representation. :

(b) The Board mambers of the party States shall each be entitied to one vote on the Board. No action of the Board shall be binding uniless a ! 
(c) The Eoard shail have a seal.

(d) The board shall elect annually, from among its nembers, d ciaiman, a vice chairman, and a treasurer. The soard shall apposint and fix the compensation of an Executive Director who shall sarve at its pleasure and who shall also act as Secretary, and who, together with the Treasurer, and such other personnel as the Board may direct, shall be bonded in such amounts as the baard may requira.

(e) The Executive Director, with the approval of the Board, shall appoint and remove or discharge such personnel as may be necessary for the performance of the Board's functions irrespective of the civil service, personnel or other merit system laws of any of the party States.

(f) The Board may establish and maintain, independently or in conjunction with any one or more of the party States, or its institutions or subdivisions, a suitable retirement system for its full-time employees. Employees of the Board shall be eligible for social security coverage in respect of old age and survivors insurance provided that the Board takes such steps as may be necessary pursuant to Federal law to participate in such program of insurance as a governiental agency or unit. The Board may establish and maintain or participate in such additional programs of enployee benefits as may be appropriate.

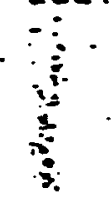

(g) The Board may accept, or contract for the services of personnel froin any State or the United States or any subdivision or agency thereof, from any interstate agency, or from any institution, person, firm or corporation. 
(h) The Eoard may accept for any of its purposes and functions under this Compat any and all donations, and grants of money, equipinant, supplies, miterials and services (conditional or otherwise) from any State or the united States or any subdivision or agency thereof, or interstata asency, or from any institution, person, firm, or corporation, and may is receive, utilize, and dispose of the same. The nature, arount and conditions, if any, attendant upon any donation or grant accepted pursuant to this paragraph together with the identity of the donar grantor or lendor, shall be detailed in the annual report of the Board.

(i) The Board shall adopt bylaws, rules and regulations for the conduct of its business, and shall have the power to amend and recind these bylaws, rules, and regulations. The Board shall publish its byiaws, rules, and regulations in convenient form and shall "file a copy thereof, and shall also file a copy along with any amendnents thereto, with the appropriate agency or officer in each of the party States.

(j) The Board annually shall make to the Governor of each party State, a report covering the activities of the Board for the preceding year, and embodying such recomendations as may have been adopted by the Board, which report shall be transmitted to the legislature of said State. The Board may issue such additional reports as it may deem desirable.

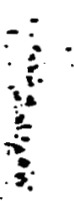




\section{ARTICLE IV}

\section{FIRANICES}

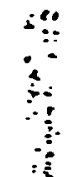

(a) The Board shall submit to the governor or dasignated officer or officers of each party State a budget of its estimated expenditures for such period as mey be required by the laws of that state for presentation to the legislature thereof.

(b) The Board's budgets of estimated expenditures for its operation shall each contain specific recomendations of the amount or amounts to be appropriated by each of the party States. Each of the Board's requests for appropriations pursuant to a budget of estimated expenditures shall be apportioned equally anong the party States. Subject to appropriation by the ir respective legislatures, the Board shall be provided with such funds by each of the party states as are necessary to provide the means of establishing and maintaining facilities, a staff of personnel, and such activities as may be necessary to fulfill the powers and duties imposed upon and entrusted to the Board, but not including costs of disposal site(s) preparation or operation.

(c) The Board may meet any of its obligations in, whole or in part with funds available to it under Article III (h) of this Compact, provided that the Board takes specific action setting aside such funds prior to the $\because$ incurring of any obligations to be met in whole or in part in this manner. Except where the Board makes use of funds available to it under Article III (h) hereof, the Board shall not incur any obligation prior to 
the aliotinent of funds by the party jurisdictions adequate to meet the sine.

$\therefore$ (d) Any expenses and any cther costs for each manter of the joard in attending board meetings shall be met by the Board.

is

(e) The Board shall keep accurate accounts of all receipts and disbursements. The receipts and disbursements of the Board shall be subject to the audit and accounting procedures established under its bylaws. However, all receipts and disbursements of funds handled by the Board shall be audited yearly by a certified or licensed public accountant and the report of the audit shall be included in and become a part of the annual report of the Board.

(f) The accounts of the Board shall be open at any reasonable time for inspection to persons authorized by the Board, and duly designated representatives of governments contributing to the Board's support.

\section{ARTICLE $V$}

\section{ADVISORY CORAMITTEES}

The Board may establish such advisory and technical committees as it miay deem necessary, membership. on which may include but not be limited to pivate citizens, expert and lay personnel, representatives of industry, iabor, comerce, agriculture, civic associations, medicine, education, voluntary health agencies, and officials of local, State and Federal 
Governiment, and riay cooperate with and use the services of any such corkititees and the organizztions wich they represent in furtinering any of its activities under this conpact.

\section{ARTICLE VI}

\section{POWERS}

The Board shall have power to--

(a) Encourage and promote cooperation among the party States in developing and instituting those technologies and procedures necessary for the safe handling, transport, treatment, and storage or disposal of low-level radioactive waste.

(b) The Board shall, in cooperation with the party States, determine those areas within their geographic boundaries suitable for the storage or disposal of that low-level radioactive waste generated with in the party States.

(c) The Board shall, from those areas identifed in paragraph (b), select that area or areas to be developed into low-level radioactive waste (may centract $\longrightarrow$ storage or disposal site(s). The Board shall be responsible for contracting with a private party or concern for the development and for the operation of the radioactive waste storage or disposal site(s) selected. 
(d) The board shall establish those fees and charges to be assessed

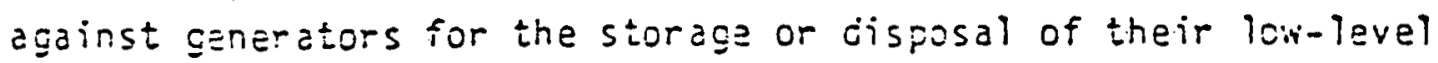
radicactive waste. Said fees and charges shall cover but not necessarily be limited to:

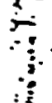

1. Cost of operation and maintenance of the storage or disposal site $(s)$.

2. Cost of liability insurance if said insurance is required by the laws of the State in which the storage or disposal site(s) is located.

3. A prorated portion of the fees and charges, the amount of which - to be established by the Board, shall be placed in a trust fund with the State in wich the storage or disposal site(s) is located to cover the cost of decomissioning and subsequent extended care of the storage or disposal site(s) after said site has reached the end of its useful life.

4. Should the Board cuntract with a private party. nr concern for the operation of a low-level radioactive waste disposal site, the fees and charges shall contain a profit margin for the party or concern. Said profit margin is to be established by the Board.

5. At the discretion of the Board, the fee and charges ma also include a profit margin for the host state. Said revenue to be 
transfierred to the General Operating Fund of the host State at the end of that State's each fiscal year.

(e) The Board shall establish those specifications relative radiation or nuclide limitations, radiation levels, no isture fixation, packaging, segregation, and any other specification which the Board may deem necessary for the iow-level radioactive waste to be in suitable form prior to disposal.

(f) The Board shall establish those disposal site monitoring requirements necessary to ensure short - and long-tarm containment of the radioactive waste, and for protection of the surrounding population and the environment.

(g) The Board shall develop a reporting and manifest system which will render complete accounting of the low-level radioactive waste from the generator to final disposal including disposal location within the storage or disposal site of each waste shipment.

(h) The Board shall develop site security measures which will include but need not be limited to, site security fencing, alarms, posting, security personnel, radiation monitoring (personnel and equipment), property security, and exclusion of unauthorized personnel. :-

(i) The Board shall establish personnel training requirements witich shall include but need not be limited to radiation protection, equipment. : operation, contingency plans, and site security. 
(j) The Eoard shall develop contingency plans witich shall address but reed not be limited to such contingencies as spills and repackaging, netural phenonena (fires, explosions, earthquakes, fioods, etc.),

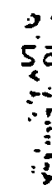

(k) The soard shall develop decomissioning and extended care plans for the low-level radioactive waste disposal site(s) when said site(s) reach the end of their useful life.

(1) The Board shall prepare, maintain, and implement a regional plan or regional plans for carrying out the duties, powers, or functions. conferred upon the Board by this Compact.

\section{ARTICLE VII}

\section{SUPPLEMENTARY AGREEMENTS(a)}

(a) To the extent that the Board has not undertaken an activity or project which would be within its power under the provisions of Article VI of this Compact, any two or more of the party States (acting by their duly constituted adninistrative officials) may enter into supplementary

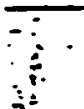
studies if it is to their benefit to do so.
}

a. Supplementary agreements give state(s) the right to perform studies pertaining to low-level waste without first obtaining Board approval, yet leeping the Eoard informed of said studies and the results obtained. It also gives the Board the option of assisting in the funding of these 
agreenents for the undertaking and continuance of such an activity or project. fay such ag Eements shall specify the purpose or purposes; its duration and the procedure for termination theraf or withdrawal. the activity or project; and such other matters as may be necessary or appropriate.

No such supplementary agreement entered into pursuant to this article shall become effective prior to its submission to and approval by the Board. The Board shall give such approval unless it finds that the supplementary agreement or activity or project contemplated thereby is inconsistent with the provisions of this Compact or with a program or activity conducted by or participated in by the Board.

(b) Unless all of the party States participate in a suppiemantary agreement, any cost or costs thereof shall be borne separately by the States party thereto. However, the Board may administer or otherwise assist in the operation of any supplementary agreement.

(c) No party to a supplementary agreement entered into pursuant to this article shall be relieved thereby of any obligation or duty assumed by said party State under or pursuant to this Compact, except that timely and proper performance of such obligation or duty by means of the -: supplementary agreement may be offered as performance pursuant to the ismpact. 
(d) Tre provisions of this article shall apply to supplenentary Egresinents and activities thereunder, but shall not be construed to repeal or impzir any authority which officers or agencies of party States ney save pursuant to other laws to undertzke cosperative arrangenents: or

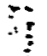
pִojects.

\section{ARTICLE VIII}

\section{OTHER LAHS ANO RELATIONS}

Nothing in this Compact shall be construed to--

(a) Permit or require any person or other entity to avoid or refuse compliance with any law, rule, regulation, order or ordinance of a party State or subdivision thereof now in existence or hereinafter enacted.

(b) Limit, diminish, or otherwise impair jurisdiction exercised by the Nuclear Regulatory Commission, any agency successor thereto, or any other federal department, agency or officer pursuant to and in conformity with any valid and operative act of Congress; nor limit, diminish, affect, or otherwise impair jurisdiction exercised by any officer or agency of a party State, except to the extent that the provisions of this Compact may provide therefor.

:

(c) Alter the relations between, and the respective internai responsiblities of, the government of a party state and its subdivisions. 
(d) Permit or authorize the Eoard to own or operate any disposal facility, process equipinent, transport equipnent or any other appurtenances thereto for comercial purposes.

(a) Ary or all of the States of

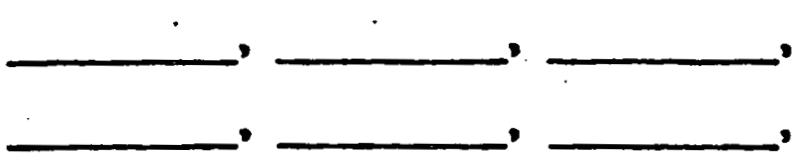
, and shall be eligible to

become party to this Compact.

(b) As to any eligible party State, this Compact shall become effective when its legislature shall have enacted the same into law; provided that it shall not become initially effective until enacted into law by States, and aiter ratification by the Congress of the United

States pursuant to Article I,. Section 10, cl. 3 of the Constitution of the United States which States that any State may with "ro consent or Congress... enter into any AGREEMENT or COMPACT with another State."

(c) Any party State may withdraw from this Compact by enacting a statute repealing the same, but no such withdrawal shall becone effective $\therefore$ until two years after the Governor of the withdrawing State shall have int formal notice in writing to the Governor of each other party State informing said Governors of the action of the legislature in repealing the Compact and declaring an intention to withdraw. A withdrawing State shall 
be liable for any cbligations which it riay have incurred on account of its farty status up to the effective data of witidrixal, except tirat if the withdring state has specifically undertaken or comitited itself to any performance of an obligation extending beyond the effective date 7 if thorawal it shall remain liable to the extent of such obligation.

\section{ARTICLE $X$}

\section{SEVERABILITY AND CONSTRUCTION}

The provisions of this Compact and of any supplementary agreement entered into hereunder shall be severable and if any phase, clause, sentence or provision of this Compact or such supplementary agreement is declared to be contrary to the Constitution of any participating State or of the United States or the applicability thereof to any government, agency, person, or circumstance is held invalid, the validity of the remainder of this Compact or such supplementary agreenent and the applicability thereof to any government, agency, person, or circumstance shall not be affected thereby. If this Compact or any supplementary agreement entered into hereunder shall be held contrary to the Constitution of any State participating therein, the Compact or such supplementary agreement shall remain in full force and effect as to the State affected as to all severable matters. The provisions of this $-\therefore$

- Compact and of any supplementary agreement entered into pursuant thereto

stiall be liberally construed to effectuate the purposes thereof. 


\section{TABLE OF CONTENTS}

\section{PART I: RADIATION PROTECTION RULES, OHIO} ADMINISTRATIVE CODE

\section{Chapter 3701-38 - General Radiation Protection Standards}

Rule 3701.38.01 IRule 3701.38.02 Riule 3701.38 .03 liule 3701.38 .0 .1 Rulc 3701.38 .05 Itule 3701.38 .06 Itule 3701.38.07 llule 3701.38 .08 Rule 3701.38.09 Ilute $3701.38 \cdot 10$ Rule 3701.38-11

Rule 3701-38.12 Itule 3701.38.13

IRule 3701.38.14 Rule 3701.38.15

Rule 3701.38.16 Kule 3701-38.17 Itule 3701.38.18 Rule 3701.38-19 It ule 3701.38.20 Rule 3701-38.21 Rule 3701.38.22

Rule 3701.38.23 Rule 3701-38-24 Rule 3701.38.25

Rule 3701-38.26

Rule 3701-38.27

Rule 3701-38.28 Kule 3701.38 .29 Hule 3701.38-30

Ilule 3701-38.31
Definition .................. 1 Scope ...................... 4 Exemptions . . . . . . . . . . . . . 4 Prohibited application of radiation to humans. . . . . 4 Communications................ 5 Registration ................ Exemptions from registration $\ldots \ldots \ldots \ldots \ldots, 6$ Records (of radiation sources) . . . . . . . . 8

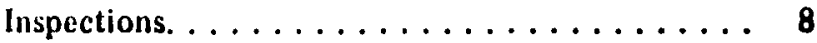
I'ests. . . . . . . . . . . . . . 8 Exposure of individuals to radiation in restricted areas ............... 9 Determination of accumulated dose . . . . . . . 10 Exposure of individuals to concentrations of radioactive material in restricted areas . . . . . . 11 Exposure of minors . . . . . . . . . . . . . 13 Purmissible levels of radiation from external sources in unrestricted areas . . . . . . . . 13 Concentration in effluents to unrestricted areas. . . 14 Orders requiring furnishing of bio-assay services . . 16 Surveys . . . . . . . . . . . . . . . 16

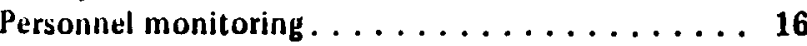
Caution signs, labels, and signals. . . . . . . . . 16

Exceptions from posting requirements. . . . . . . 19 Instruction of personnel; posting of notice

to employees $\ldots \ldots \ldots \ldots \ldots \ldots \ldots \ldots 20$ Storage of radiation sources. . . . . . . . . . 21 Leak testing of sealed sources . . . . . . . . . 21 General requirements for disposal of radiouctive material . . . . . . . . . . . . . . 22 Method of obtaining approval of proposed disposal procedures . . . . . . . . . . . . 22 Disposal by release into sanitary sewerage

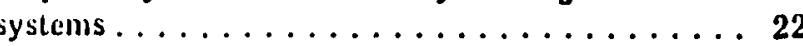
Jisposal by burial in soil. . . . . . . . . 23 Disposal by incineration . . . . . . . . . 23 Recurds of surveys, radiation monitoring, and disposal . ................. 23 lteports of theft or loss of radiation sources ................... 24 Notification of incidents. . . . . . . . 24
Rule 3701-38.34

Rule 3701-38-35

Rule 3701.38.36

Rule 3701-38-37

Chapter 3701-39 - Special Radiation Protection Requirements for Industrial Radiographic Operations

Rule 3701.39.01

Rule 3701-39.02

Rule 3701.39.03

Rule 3701-39.04

Rule 3701-39.05

Rule 3701-39.06

Rule 3701.39.07

Rule 3701.39.08

Rule 3701-39-09

Rule 3701.39.10

Rule 3701-39-11

Rule 3701-39.12

Rule 3701-39-13

Rule 3701.39-14

Rule 3701-39.15

Rule 3701-39-16

Chapter 3701.40 - Special Radiation Protection Requirements for the Use of Radiation in the Healing Arts
Rule 3701.40-01

Rule 3701.40.02

Rule 3701.40.03

Rule 3701.40.04

Rule 3701-40-05

Rule 3701.40.06

Rule 3701-40.07

Rule 3801-40.08
Report to former employees and others

of exposure to radiation . . . . . . . . . . . 25

Reports of exposures, levels, and concentrations

in excess of applicable limits . . . . . . . . 25

Notice to employees and others of exposure

to radiation ..................26

Vacating premises ............... 26

Intrastate transportation of radioactive

materials ...................27 .

\section{.} Purpose and scope.............. 29 Limits on levels of radiation for radiographic exposure devices and storage containers. . . . . . . 29 Locking of sources of radiation . . . . . . . . . 29 Storage precautions . . . . . . . . . . . . . 30 Radiation survey instruments. . . . . . . . . . 30 Leak testing, repair, tagging, opening, modification, and replacement of sealed sources ...................... 30 Quarterly inventory ................ 30 Utilization $\operatorname{logs} \ldots \ldots \ldots \ldots \ldots \ldots \ldots \ldots$ Limitations .................... 31 Operating and emergency procedures . . . . . . . 32 Personnel monitoring control. . . . . . . . . . . 33 Security. ................... 33 Posting .................... 33 Radiation surveys and survey records ........33 Special requirements for radiography employing radiation machines . . . . . . . . .

Definitions. . . . . . . . . . . . . . . 35 Purpose and scope . . . . . . . . . . . . . 36 General X-ray safety provisions . . . . . . . . 37 Prohibited use. . . . . . . . . . . . . . 37 Fluoroscopic X-ray installations. . . . . . . . . 37 Radiographic installations other than dental and veterinary medicine. . . . . . . . . 39 Special requirements for mobile diagnostic radiographic equipment ..............40 Special requirements for chest photofluorographic installations. . . . . . 
Itule 3701-40.12 Rulc 3701.40.13

Dental radiographic installations. . . . . . . . . 41 Therapeutic X-ray installations. . . . . . . . . . . 42 Special requirements for X-ray therapy equipment operated at potentials of

sixly (60) KV and below. . . . . . . . . . . . 44 Veterinary medicine radiographic installations . . . 45 Interstitial, in tracavitary and superficial

applications of radiation from sealed sources . . . . 46

Chapter 3701.41 - Preventing the Use of Fluoroscopes for Shoe Fitting Purposus

Rule 3701.41.01

Prohibited use. . . . . . . . . . . . . 47

Kule 3701-41.02

Prohibited transfers . . . . . . . . . . . 47

\section{PART II: RADIATION PROTECTION STATUTES, OHIO REVISED CODE}

Section 3701.90

Section 3701.91

Section 3701.92

Section 3701.93

Section 3701.94

Seclion 3701.95

Section 3701.96

Section 3701.97

Section 3701.98

Section 3701.99

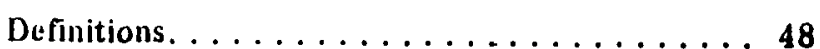
Regulations .............. 48 Powers and duties of director. . . . . . 49. Radiation Advisory Council; duties. . . . . . . . . 50 Handling sources of radiation. . . . . . . . 51 Prosecution for violations; injunctions. . . . . . 51 Exception of radiation for medical purposes. . . . . 51 Notice of violation; proceedings; declaration

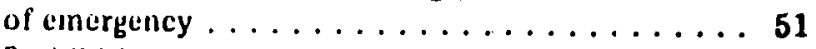
Prohibition. ............... 52 Penalties .................. 52

\section{CHAPTER 3701-38}

GENERAL RADIATION PROTECTION STANDARDS

Adopted February 15, 1969; effective July 1, 1969

Authority: Section 3701.91, Ohio Revised Code

Rule 3701-38-01. Definitions.

As used in rules 3701-38-01 to 3701-38-37 of the Ohio Administra tive Code.

(A) "Act" means sections 3701.90 to 3701.99 of the Revised Code

(B) "Airborne radioactive material" means any radioactive materia dispersed in the air in the form of dusts, fumes, mists, vapors, of gases.

(C) "Calendar quarter" means any period determined according tc either of the following subdivisions:

(1) The first period of any year may begin on any date in January provided that the second, third and fourth periods accordingly be gin on the same date in April, July and October, respectively, anc that the fourth period extend into January of the succeeding year. if necessary to complete a three-month quarter. During the firsi year of use of this method of determination by a registrant, the first period for that year shall also include any additional days in Jan. uary preceding the starting date of the first period.

(2) The first period in a calendar year of thirteen (13) complete: consecutive calendar weeks; the second period in a calendar year of thirteen (13) complete, consecutive calendar weeks; the third period in a calendar year of thirteen (13) complete, consecutive calendar weeks; the fourth period in a calendar year of thirteen (13) complete, consecutive calendar weeks. Alternatively, the four periods may consist of the first fourteen (14) complete, consecutive calendar weeks; the next twelve (12) complete, consecutive. calendar weeks; the next fourteen (14) complete, consecutive calendar weeks; and the last twelve (12) complete, consecutive calendar weeks. If at the end of a calendar year there are any days not falling. within a complete calendar week of that year, such days shall be included within the last complete calendar week of the previous year. No registrant shall change the method observed by him of determining calendar quarters except at the beginning of a calendar year.

(D) "Curie" (Ci) means that quantity of radioactive material which decays at the rate of $3.7 \times 1010$ disintegrations per second. One microcurie (uCi) equals 0.000001 curie or $3.7 \times 10^{4}$ disintegrations per second. 
(E) "Director" means the director of the department of health of the state of Ohio.

(F) "Dose" means the quantity of radiation absorbed, per unit of mass, by the body or by any portion of the body. When a dose during a period of time is specified, the dose means the total quantity of radiation absorbed, per unit of mass, by the body or by any portion of the body during such period of time.

(G) "Iligh radiation area" means any area, accessible to individuals, in which there exists radiation at such levels that a major portion of the body could receive in any one hour a dose in excess of one hundred (100) millirems.

(II) "Individual" means any human being.

(I) "Occupational dose" means exposure of an individual to radiation (1) in a restricted area; or (2) in the course of employment in which the individual's duties involve exposure to radiation; provided, that occupational dose shall not include any exposure of an individual to radiation for medical purposes by or under the direction of a licensed practitioner of the healing arts.

(J) "OAC" means the Ohio Administrative Code.

(K) "Person" means the state, any municipal corporation, political subdivision, public or private corporation, individual, partnership, or other entity.

(L) "Personnel monitoring equipment" means devices designed to be wom or carried by an individual for the purpose of measuring the dose received (e.b., film badges, pocket chambers, pocket dosi. meters, film rings, etc.)

(M) "Rad" means a measure of the dose of any radiation to body tissues in terms of the energy absorbed per unit mass of the tissue. One rad is the dose corresponding to the absorption of one hundred (100) ergs per grami of tissue. One millirad (mrad) equals 0.001 rad.

(N) "Radiation" means gamma rays and X-rays, alpha and beta particles, high-speed electrons, neutrons, and other nuclear particles; but not sound or radio waves, or visible, infra-red, or ultra-violet light.

(O) "Radiation area" means any area, accessible to individuals, in which there exists radiation at such levels that a major portion of the body could receive in any one hour a dose in excess of five (5) millirems or in any five (5) consecutive days a dose in excess of one hundred (100) millirems.

(P) "Radioactive material" means any material, solid, liquid, or gas, which emits radiation spontaneously.

(Q) "Radiation machine" means any device capable of producing radiation except devices which produce radiation only from radioactive material.

(R) "Radiation source" means a radiation machine or radioactive material.

(S) "Registrant" means a person required by rule 3701-38-06, OAC, to register with the director.

(T) "Rem" means a measure of the dose of any radiation to body tissue in terms of its estimated biological effect relative to a dose of one roentgen ( $R$ ) of $X$-ray. One millirem (mrem) equals 0.001 rem. The relation of the rem to other dose units depends upon the biological effect under consideration and upon the conditions of irradiation. Any of the following is considered to be equivalent to a dose of one rem:

(1) A dose of one (1) roentgen due to X-radiation or gamma radiation;

(2) A dose of one (1) rad due to X-radiation, gamma radiation, or beta radiation;

(3) A dose of 0.1 rad due to neutrons or high energy protons;

(4) A dose of $0.05 \mathrm{rad}$ due to particles heavier than protons and with sufficient energy to reach the lens of the eye.

(U) "Restricted area" means any area access to which is controlled by the registrant for purposes of protection of individuals from exposure to radiation and radioactive materials; provided, area used for residential quarters are not included, although a separate room or rooms in a residential building may be set apart as a restricted area.

(V) "Roentgen" (R) means a measure of the radiation dose resulting from exposure to $\mathrm{X}$-radiation or gamma radiation of such quantity that the associated corpuscular emission, per 0.001293 grams of air produces in air ions carrying one electrostatic unit of quantity of electricity of either sign. One milliroentgen $(\mathrm{mR})$ equaals 0.001 roentgen.

(W) "Sealed source" means radioactive material that is permanently bonded or fixed in a capsule or matrix designed Jrevent release 
and dispersal of the radioactive material under the most severe conditions which are likely to be encountered in normal use and handling.

(X) "Survey" means an evaluation of the radiation protection practices incident to the production, use, release, disposal, or presence of radiation sources under a specific set of conditions. When appropriate, such evaluation includes a physical survey of the location of materials and equipment, and measurements of levels of radiation or concentrations of radioactive material present.

(Y) "Unrestricted area" means any area access to which is not controlled by the registrant for purposes of protection of individuals from exposure to radiation and radioactive materials, and any area used for residential quarters.

Rule 3701-38-02. Scope.

lixcept as otherwise specifically provided, rules 3701-38-01 to 3701 . $38-37, \mathrm{OAC}$, apply to all persons to the extent they receive, possess, use, transfer, own, or acquire any radiation source which is not sub. ject to regulation by the United States Atomic Energy Commission;1 provided that nothing in these rules shall be construed to limit or to require the measurement or the reporting of radiation which is intentionally applied to a patient for medical purposes by or under the direction of a practitioner of the healing arts licensed by the state of Ohio.

\section{Rule 3701-38-03. Exemptions}

'The director may, upon application therefor or upon his own initiative, grant such exemptions or exceptions from the requirements of rules $3701-38-01$ to $3701-38-37, \mathrm{OAC}$, as he determines are authorized by law and will not result in undue hazard to public health and sufety or property.

Rule 3701-38-04. Prohibited application of radiation to humans.

No person other than a licensed practitioner of the healing arts shall direct or order the application of radiation to any individual; nor shall any person other than a licensed practitioner or a person working under the direction or order of a licensed practitioner apply radiation to any iridividual. Such direction or order to apply or application of rulliation shall be in the course of the practitioner's professional

Ithadiation suarces not subject to regulation by the U.S. A tomic Energy Commlssion include $\mathrm{X}$-ray machinis, radium and curtain oflicer naturally occurring radioactive materials, particle acceleralurs, and cadioactive matcrials produced in particle accelerators. practice and shall comply with the requirements of $3701-38-01$ to 3701-38-37 and 3701-40-01 to 3701-40-13, OAC.

Rule 3701-38-05. Communications.

All communications and reports concerning rules 3701-38-01 to 370138-37, OAC, and registrations filed thereunder, should be addressed to the director at his office in Columbus, Ohio.2

Rule 3701-38-06. Registration.

(A) Every person having possession of any radiation source, except persons specifically exempted in rule 3701-38-07, OAC, shall:

(1) Register with the director within ten (10) days after the initial acquisition of a radiation source, on forms ${ }^{3}$ prescribed and furnished by the director, indicating the maximum numbers or quantities of radiation sources such person will have on hand at any time during the current registration period; provided, the registration of a person who registered with the director under rules in effect prior to the adoption of this rule shall remain in full force and effect through December 31, 1969.

(2) Designate an individual who will be responsible for carrying out such procedures as may be necessary to assure effective complianoe with the applicable requirements of rules 3701-38.01 to 3701-38-37, OAC. Such individual shall be qualified by training and experience to be able to inform himself of any hazards or precautions involved in handling or operating the radiation source for which he is responsible. The duties of the responsible individual may include:

(a) Recommending a detailed program of radiation safety for compliance with all applicable rules.

(b) Giving instructions concerning hazards and safety practices to individuals who may be exposed to radiation from the radiation source.

(c) Making or arranging for surveys and carrying out other procedures as required by rules 3701-38-01 to 3701-38-37, OAC.

When, in the opinion of the director, the individual designated does not have qualifications sufficient to insure safety of the radiation source for which he is responsible, the director may order the registrant to designate another individual who meets the requirements of this subdivision.

2Director of Health, Ohio Depurtunent of Health, P.O, Box 118, Columbus, Ohio 43216.

3Forin No. 6514 for radiation sources used tor medical purposes; form No. 6516 for rudlation sources used for non-rnedical purposes. 
(B) The registrant shall renew his registration with the director on or before January 1,1970 and biennially thereafter as long as the activity requiring such registration continues. ${ }^{4}$

(C) An acknowledgement of registration will be provided by the director and shall be retained by the registrant for the registration period indicated thereon.

(D) The registrant shall notify the director within ten (10) days after any change which renders the information on the initial registration no longer accurate.

(E) No person, in any advertisement, shall refer to the fact that a radiation source is registered with the director and no person shall state or imply that any activity under such registration has been approved by the director or the department of health.

Rule 3701-38-07. Exemptions from registration.

(A) Radioactive materials.

Any person is exempt from rule 3701-38-06, OAC, to the extent that such person receives, possesses, uses, transfers, owns, or acquires:

(1) Quantitites of radioactive material listed in division (B) of this regulation, provided that the possession or use of more than a total of ten (10) such scheduled quantities is not exempt.

(2) Products or materials containing radioactive material in concentrations not in excess of those listed in division (C) of this regulation.

(3) Hands or dials of timepieces and other instruments containing luminous radioactive material, provided that persons who apply luninous radioactive material to hands or dials of timepieces and other instruments are not exempt.

(4) Radioactive materials and products containing radioactive materials which are subject to regulation by the United States Atomic Energy Commission.

AA form for the renewal of registration will be mailed to each registrant during the month of December, 1 yity, and biennially liereafter.
(B) Table of exempt quantities.

\begin{tabular}{lcc}
\hline & $\begin{array}{c}\text { Column I } \\
\text { Not as a } \\
\text { Sealed Source } \\
\text { (microcuries) }\end{array}$ & $\begin{array}{c}\text { Column II } \\
\text { As a } \\
\text { Sealed Source } \\
\text { (microcuries) }\end{array}$ \\
\hline Bismuth 210 (Bi 210) & 10 & 10 \\
Lead 210 (Pb 210) & 1 & 10 \\
Polonium 210 (Po 210) & 0.1 & 1 \\
Radium 224 (Ra 224) & 1 & 10 \\
Radium 226 (Ra 226) & 0.1 & 1 \\
Radium 228 (Ra 228) & 0.1 & 1 \\
Radon 220 (Rn 220) & 1 & 10 \\
Radon 222 (Rn 222) & 1 & 10 \\
Radioactive material & 1 & \\
not listed above & & 10 \\
\hline
\end{tabular}

\section{(C) Table of exempt concentrations.}

\begin{tabular}{|c|c|c|}
\hline Radioactive Material & $\begin{array}{c}\text { Column I } \\
\text { Gas } \\
\text { concentration } \\
\text { uCi/mI }\end{array}$ & $\begin{array}{c}\text { Column II } \\
\text { Liquid and solid } \\
\text { concentration } \\
\text { uCi/mI }\end{array}$ \\
\hline Bismuth 210 (Bi 210) & & $4 \times 10^{-4}$ \\
\hline Lead $210(\mathrm{~Pb} 210)$ & & $1 \times 10^{-6}$ \\
\hline Polonium 210 (Po 210) & $2 \times 10.10$ & $7 \times 10^{-6}$ \\
\hline Radium 224 (Ra 224) & $2 \times 10^{-9}$ & $2 \times 10.5$ \\
\hline Radium 226 ( $R a ~ 226)$ & $1 \times 10.11$ & $1 \times 10-7$ \\
\hline Radium 228 ( $R a 228)$ & $3 \times 10.11$ & $3 \times 10-7$ \\
\hline Kadon 220 (Rn 220) & $1 \times 10.7$ & \\
\hline Radon 222 (Rn 222) & $1 \times 10^{-8}$ & \\
\hline $\begin{array}{l}\text { Beta and/or gamma emitters } \\
\text { not listed above with half } \\
\text { life less than } 3 \text { years. }\end{array}$ & $1 \times 10.10$ & $1 \times 10^{-6}$ \\
\hline $\begin{array}{l}\text { Radioactive material } \\
\text { not listed above }\end{array}$ & $1 \times 10 \cdot 11$ & $1 \times 10^{-7}$ \\
\hline
\end{tabular}

Note: 1: Many radioisotopes disintegrate into isotopes which are also radioactive. In expressing the concentrations in this division $(C)$, the activity stated is that of the parent isotope and takes into account the daughters.

Note 2: For a combination of isotopes, the limit for the combination should be derived as follows: Determine for each isotope in the product the ratio between its concentration in the product and the exempt concentration. The sum of such ratios may not exceed " 1 ". (unity). 
(D) Other exemptions.

'The following machines and equipment are exempt from rule 3701 38-06, OAC:

(1) Domestic television receivers, providing the dose rate at $5 \mathrm{~cm}$ from any outer surface is less than $0.5 \mathrm{mrem}$ per hour.

(2) Other electrical equipment that produces radiation incidental to its operation for other purposes, provided the dose rate to the whole body at the point of nearest approach to such equipment when any external shielding is removed does rot exceed $0.5 \mathrm{rem}$ per year. 'The production testing or factory servicing of such equipment is not exempt.

(3) Radiacion-producing machines while in transit or storage incident thereto.

Rule 3701-38-08. Records (of radiation sources). ${ }^{6}$

Each registrant shall keep records showing the receipt, transfer, and disposal of all radiation sources.

Rule 3701-38-09. Inspections.

(A) Each registrant shall afford the director or his agents at all reasonable times opportunity to inspect radiation sources and the premises and facilities wherein such radiation sources are used or stored.

(B) Each registrant shall make available to the director or his agents for inspection, upon reasonable notice, records maintained pursuant to rule $3701-38-08$, OAC.

Rule 3701-38-10. Tests.

bich registrant shall perform, upon instructions from the director, or shall permit the director to perform, such reasonable tests as the director deems appropriate or necessary including, but not limited to, tests of:

(A) Radiation sources;

(B) Facilities wherein radiation sources are used or stored;

(C) Radiation detection and monitoring instruments;

(D) Other equipment and devices used in connection with utilization or storage of registered radation sources.

5 ollier recurds - pertaining 10 surveys, radiation monitoring, and the disposal of radioactive material - may be ceyutred to be kejl by sume registrants. See rule 3701-38-30.
Rule 3701-38-11. Exposure of individuals to radiation in restricted areas. ${ }^{6}$

(A) Except as provided in division (B) of this regulation, no registrant shall possess, use, receive, or transfer radiation sources in such a manner as to cause any individual in a restricted area to receive in any period of one calendar quarter from all radiation sources in the registrant's possession a dose in excess of the limits specified in the following table:

Rems per calendar quarter

Whole body; head and trunk; active blood-forming organs; lens of eyes; or gonads.

Hands and forearms; feet and ankles.

Skin of whole body.

(B) A registrant may permit an individual in a restricted area to receive a dose to the whole body greater than that permitted under division (A) of this rule, provided:

(1) During any calendar quarter the dose to the whole body from sources of radiation in the registrant's possession shall not exceed three (3) rems;

(2) The dose to the whole body, when added to the accumulated occupational dose to the whole body, shall not exceed $5(N-18)$ rems where " $N$ " equals the individual's age in years at his last birthday.

(3) The registrant has determined the individual's accumulated occupational dose to the whole body on a form ${ }^{7}$ prescribed and provided for this purpose by the director or on a clear and legible record containing all the information required in that form, and has otherwise complied with the requirements of rule 3701-38-12, OAC. As used in division (B) of this rule, "dose to the whole body" shall include any dose to the whole body, gonads, active blood-forming organs, head and trunk, or lens of eye.

${ }^{6}$ Most registrants will not find if necessary to permit exposures in excess of the limits eatablished in division (A) of this rule and may, therefore, ignore division (B) of this rule and all of rule 3701-38-12.

7 Form No. 4816. 
Rule 3701-38-12. Determination of accumulated dose.

(A) This regulation contains requirements which must be satisified by registrants who propose, pursuant to division (B) of rule 3701-38-11, $\mathrm{OAC}$, to permit individuals in restricted areas to receive exposure to radiation in excess of the limits specified in division (A) of rule $3701-38-11$, OAC.

(B) Before permitting any individual in a restricted area to receive exposure to radiation in excess of the limits specified in division (A) of rule 3701-38-11, OAC, each registrant shall:

(1) Obtain a certificate on the form 7 referred to in subdivision (B) (3) of 3701-38-11, OAC, or on a clear and legible record containing all the information required in that form, signed by the individual, showing each period of time after the individual attained the age of eighteen (18) in which the individual received an occupational dose of radiation;

(2) Calculate on the form in accordance with the instructions appearing therein, or on a clear and legible record containing all the information required in the form, the previously accumulated occupational dose received by the individual and the additional dose allowed for that individual under division (B) of rule 3701$38-11, O \wedge C$

(C) (1) In the preparation of the form, or a clear and legible record containing all the information required in the form, the registrant shall make a reasonable effort to obtain reports of the inclividual's previously accumulated occupational dose. For each period for which the registrant obtains such reports, he shall use the period shown in the report in preparing the form. In any case where a registrant is unable to obtain reports of the individual's occupational dose for a previous complete calendar quarter, it shall be assumed that the individual has received the occupational dose specified in whichever of the following columns apply:

\begin{tabular}{lcc} 
Part of body & $\begin{array}{c}\text { Assumed dose in } \\
\text { rems for calendar } \\
\text { quarters prior to } \\
\text { January } 1, \mathbf{1 9 6 1}\end{array}$ & $\begin{array}{c}\text { Assumed dose in rems } \\
\text { for calendar quarters } \\
\text { beginning on or after } \\
\text { January 1, 1961 }\end{array}$ \\
\hline $\begin{array}{l}\text { Whole body, } \\
\text { gumads, active blood. } \\
\text { furming organs, head and } \\
\text { trunk, lens of eye }\end{array}$ & $3 \% 4$ & $1 \%$ \\
\hline
\end{tabular}

(2) The registrant shall retain and preserve records used in preparing the form. If calculation of the individual's accumulated occu10) Tiurm Na. pational dose for all periods prior to January 1,1961 , yields a result higher than the applicable accumulated dose value for the individual as of that date, as specified in division (B) of rule 3701-38-11, OAC, the excess may be disregarded.

Rule 3701-38-13. Exposure of individuals to concentrations of radioactive material in restricted areas.

(A) No registrant shall possess, use, receive, or transfer radioactive material in such a manner as to cause an individual in a restricted area to be exposed to airborne radioactive material in an average concentration in excess of the limits specified in division (D), Part I, of this rule. "Expose," as used in this rule, means that the individual is present in an airborne concentration. No allowance shall be made for the use of protective clothing or equipment, or particle size, except as authorized by the director pursuant to division (C) of this rule.

(B) The limits given in division (D), Part I, of this rule are based upon exposure to the concentrations specified for forty (40) hours in any period of seven (7) consecutive days. In any such period where the number of hours of exposure is less than forty, the limits specified in division (D), Part $I$, of this rule may be increased proportionately. In any such period where the number of hours of exposure is greater than forty (40), the limits specified in division (D), Part I, of this rule shall be decreased proportionately.

(C) (1) Except as authorized by the director pursuant to this division, no allowance shall be made for particle size or the use of protec. tive clothing or equipment in determining whether an individual is exposed to an airborne concentration in excess of the limits specified in division (D), Part $\mathrm{I}$, of this rule.

(2) The director may authorize a registrant to expose an individual in a restricted area to airborne concentrations in excess of the limits specified in division (D), Part $I$, of this rule upon receipt of an application demonstrating that the concentration is composed in whole or in part of particles of such size that such particles are not respirable and that the individual will not inhale the concentrations in excess of the limits established in division (D), Part I, of this rule. Each application under this subdivision shall include an analysis of particle sizes in the concentrations and a description of the methods used in determining the particle sizes.

(3) The director may authorize a registrant to expose an individual in a restricted area to airborne concentrations in excess of the 
limits specified in division (D), Part I, of this rule, upon receipt of an application demonstrating that the individual will not inhalc, ingest, or absorb quantities of radioactive material in excess of those which might otherwise be permitted under this regulation for individuals in restricted areas during a 40-hour week. Each application under this subdivision shall contain the following in formation:

(a) A description of the protective equipment to be employed, including the efficiency of the equipment for the material involved:

(b) l'rocedure for the fitting, maintenance, and cleaning of the prolective equipment;

(c) Procedures governing the use of the protective equipment, including supervisory procedures and length of time the equipment will be used by the individuals in each work week. The proposed periods for use of the equipment by an individual shall not be of such duration as would disccurage observance by the individual of the proposed procedures;

(d) The average concentrations present in the areas occupied by individuals.

(D) Table of concentrations in air and water above natural background.

\begin{tabular}{|c|c|c|c|c|c|}
\hline \multirow[b]{2}{*}{$\begin{array}{l}\text { Radioactive } \\
\text { malerial }\end{array}$} & \multirow[b]{2}{*}{ olubility } & \multicolumn{2}{|c|}{ Part I } & \multicolumn{2}{|c|}{ Part II } \\
\hline & & $\begin{array}{c}\text { Column } 1 \\
\text { Air } \\
(u \mathrm{Ci} / \mathrm{ml})\end{array}$ & $\begin{array}{c}\text { Column } 2 \\
\text { Water } \\
(\mathrm{uCi} / \mathrm{ml})\end{array}$ & $\begin{array}{c}\text { Column } 1 \\
\text { Air } \\
(\mathrm{uCi} / \mathrm{ml})\end{array}$ & $\begin{array}{l}\text { Column } 2 \\
\text { Water } \\
\text { (uCi/ml) }\end{array}$ \\
\hline Bismull $210(\mathrm{Bi} 210)$ & S & $\begin{array}{l}6 \times 10^{-9} \\
6 \times 10^{-9}\end{array}$ & $1 \times 10^{-3}$ & $\begin{array}{l}2 \times 10^{-10} \\
2 \times 10^{-10}\end{array}$ & $4 \times 10^{-5}$ \\
\hline Lead $210(\mathrm{~Pb} 210)$ & S & $\begin{array}{l}1 \times 10^{-10} \\
2 \times 10^{-10}\end{array}$ & $\begin{array}{l}4 \times 10^{-6} \\
5 \times 10^{-3}\end{array}$ & $\begin{array}{l}4 \times 10^{-12} \\
8 \times 10^{-12}\end{array}$ & $\begin{array}{l}1 \times 10^{-7} \\
2 \times 10^{-4}\end{array}$ \\
\hline Polunium 210 (Po 210) & 0) $\mathrm{S}$ & $\begin{array}{l}5 \times 10^{-10} \\
2 \times 10^{-10}\end{array}$ & $\begin{array}{l}2 \times 10^{-5} \\
8 \times 10^{-4}\end{array}$ & $\begin{array}{l}2 \times 10^{-11} \\
7 \times 10^{-12}\end{array}$ & $\begin{array}{l}7 \times 10^{-7} \\
3 \times 10^{-5}\end{array}$ \\
\hline Radium 224 (R: 224) & S & $\begin{array}{l}5 \times 10^{-9} \\
7 \times 10^{-10}\end{array}$ & $\begin{array}{l}7 \times 10^{-5} \\
2 \times 10^{-4}\end{array}$ & $\begin{array}{l}2 \times 10^{-10} \\
2 \times 10^{-11}\end{array}$ & $\begin{array}{l}2 \times 10^{-6} \\
5 \times 10^{-6}\end{array}$ \\
\hline Radium 226 (Ra 226) & S & $\begin{array}{l}3 \times 10^{-11} \\
5 \times 10^{-11}\end{array}$ & $\begin{array}{l}4 \times 10^{-7} \\
9 \times 10^{-4}\end{array}$ & $\begin{array}{l}3 \times 10^{-12} \\
2 \times 10^{-12}\end{array}$ & $\begin{array}{l}3 \times 10^{-8} \\
3 \times 10^{-5}\end{array}$ \\
\hline Radlium 228 (Ra 228) & $\mathrm{S}$ & $\begin{array}{l}7 \times 10^{-11} \\
4 \times 10^{-11}\end{array}$ & $\begin{array}{l}8 \times 10^{-7} \\
7 \times 10^{-4}\end{array}$ & $\begin{array}{l}2 \times 10^{-12} \\
1 \times 10^{-12}\end{array}$ & $\begin{array}{l}3 \times 10^{-8} \\
3 \times 10^{-5}\end{array}$ \\
\hline Radlon $2: 0\left(R_{n} 220\right)$ & . & $3 \times 10^{-7}$ & - & $1 \times 10^{-8}$ & . \\
\hline Kadon $2.20(K n 22)$ & - & $1 \times 10^{-7}$ & - & $3 \times 10^{-9}$ & - \\
\hline 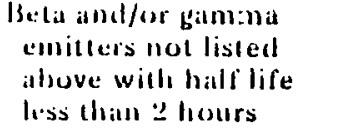 & - & $1 \times 10^{-6}$ & - & $3 \times 10^{-8}$ & - \\
\hline $\begin{array}{l}\text { Belat and/or filmona } \\
\text { emillers not lisled } \\
\text { abuve with hall life } \\
\text { grealer thang liours }\end{array}$ & - & $3 \times 10^{-9}$ & $9 \times 10^{-5}$ & $1 \times 10^{-10}$ & $\begin{array}{c}3 \times 10^{-6} \\
.\end{array}$ \\
\hline $\begin{array}{l}\text { Alpha emilters not } \\
\text { listed above }\end{array}$ & - & $6 \times 10^{-13}$ & $4 \times 10^{-7}$ & $2 \times 10^{-14}$ & $3 \times 10^{-8}$ \\
\hline
\end{tabular}

Note: In any case where there is a mixture in air or water of more than one radionuclide. the limiting values for purposes of this 'fable should be determined as follows:

1. If the identity and concentration of each radionuclide in the mixture are known. the limiting value should be derived as follows: Determine, for euch radionuclide in the mixture, the ratio between its concentration in the mixture and its limiting concentration established in this table. The sum of such ratioy for all radionuclides in the mixture shall not exceed " $l$ " (unity).

2. If either the identity or the concentration of any radionuclide in the mixture is not known, the limiting values for purposes of this table shall be the same as those shown at the bottom of the table for "Alpha emitters not listed above."

3. If the identity of each radionuclide in the mixture is known but the concentration of one or more of the radionuclides in the mixture is not known, the concentration limit for the mixture is the limit specified in this table for the radionuclide in the mixture having lowest concentration limit.

Rule 3701-38-14. Exposure of minors.

(A) No registrant shall possess, use, or transfer radiation sources in such a manner as to cause any individual within a restricted area, who is under eighteen (18) years of age, to receive in any period of one calendar quarter, from all radiation sources in such registrant's possession, a dose in excess of ten (10) percent of the limits specified in the table in division $(\mathrm{A})$ of rule 3701-38-11, 0AC.

(B) No registrant shall possess, use, or transfer radioactive material in such a manner as to cause any individual within a restricted area, who is under eighteen (18) years of age, to be exposed to airborne radioactive material in an average concentration in excess of the limits specified in division (D), Part II, of rule 3701-38-13, OAC. For purposes of this rule, concentrations may be averaged over periods not greater than a week.

(C) The provisions of division (C) of rule 3701-38-13, OAC, shall ap. ply to exposures subject to division (B) of rule 3701-38-14, OAC.

Rule 3701-38-15. Permissible levels of radiation from external sources in unrestricted areas.

(A) Except as authorized by the director pursuant to division (B) of this rule no registrant shall possess, use, or transfer radiation sources in such a manner as to create in any unrestricted area from such radiation sources in his possession:

(1) Radiation levels which, if an individual were continuously present in the area, could result in his receiving a dose in excess of two millirems in any one hour; or, 
(2) Radiation levels which, if an individual were continuously present in the area, could result in his receiving a dose in excess of $\mathbf{1 0 0}$ millirems in any seven consecutive days.9

(B) Any person may apply to the director for proposed limits upon levels of radiation in unrestricted areas in excess of those specified in division $(A)$ of this rule resulting from the applicant's possession or use of radiation sources. Such applications should include information as to anticipated average radiation levels and anticipated occupancy times for each unrestricted area involved. The direcLor shall approve the proposed limits if the applicant demonstrates to the salisfaction of the director that the proposed limits are not likely to cause any individual to receive a dose to the whole body in any period of one calendar year in excess of $0.5 \mathrm{rem}$.

Rule 3701-38-16. Concentration in effluents to unrestricted areas.

A) A registrant shall not possess, use, or transfer radioactive material so as to release to an unrestricted area radioactive material in concentrations which exceed the limits specified in division (D), Part II, of rule 3701-38-13, OAC, except as authorized pursuant to rule $3701-38-26, O A C$, or division (B) of this rule. For purposes of this. rule concentrations may be averaged over a period not greater than one year.

B) Any person may apply to the director for proposed limits upon concentritions of radioactive material released into air or water in unrestricted areas in excess of those specified in division (A) of this rule as a result of applicant's proposed activities. The director shall approve the proposed linits if the applicant demonstrates:

(1) That the applicant has made a reasonable effort to minimize the radioactivity contained in effluents to unrestricted areas;

(2) 'lhat it is not likely that radioactive material discharged in the effluent would result in the exposure of an individual to concentrations of radioactive material in air or water exceeding the limits specified in division (D), Part II, of rule 3701-38-13, OAC.

) An application for higher limits pursuant to division (B) of this rule shall inclide information demonstrating that the applicant has marle a reasonable effort to minimize the radioactivity discharged in effhents to unrestricted areas, and shall include, as pertinent: (1) Information as to flow rates, total volume of effluent, peak concentration of each raclionuclide in the effluent, and concentration

1 applying subdivision (A) (2) of rule 3701-38-15 it must be assumed that an individual nid be preseint ith the area 2 t hours per day foz a total of 168 hours in 7 consecutive days less it can lie demunstrated that such continuous uccupancy is not possible. of each radionuclide in the effluent averaged over a period of one year at the point where the effluent leaves a stack, tube, pipe, or similar conduit.

(2) A description of the properties of the effluents, including:

(a) Chemical composition;

(b) Physical characteristics, including suspended solids content in liquid effluents, and nature of gas or aerosol for air effluents;

(c) The hydrogen ion concentrations $\left(\mathrm{p}^{\mathrm{H}}\right.$ ) of liquid effluents;

(d) The size range of particulates in effluents released into air.

(3) A description of the anticipated human occupancy in the unrestricted area where the highest concentration of radioactive material from the effluent is expected, and, in the case of a river or stream, a description of water uses downstream from the point of release of the effluent.

(4) Information as to the highest concentration of each radionuclide in an unrestricted area, including anticipated concentrations averaged over a period of one year:

(a) In air at any point of human occupancy; or,

(b) In water at points of use downstream from the point of release of the effluent.

(5) The background concentration of radionuclides in the receiving river or stream prior to the release of liquid effluent.

(6) A description of the environmental monitoring equipment, in. cluding sensitivity of the system, and procedures and calculations to determine concentrations of radionuclides in the unrestricted area and possible reconcentrations of radionuclides.

(7) A description of the waste treatment facilities and procedures used to reduce the concentration of radionuclides in effluents prior to their release.

(D) For the purposes of this rule, the concentration limits in division (D), Part II, of rule 3701-38-13, OAC, shall apply at the boundary of the restricted area. The concentration of radioactive material discharged through a stack, pipe or similar conduit may be determined with respect to the point where the material leaves the conduit. If the conduit discharges within the restricted area, the concentration at the boundary may be determined by applying appropriate factors for dilution, dispersion, or decay between the points of discharge and the boundary.

(E) In addition to limiting concentrations in effluent streams, the director may limit quantities of radioactive materials released in air or water during a specified period of time if it appears that the daily intake of radioactive material from air, water, or food by a 
suitable sample of an exposed population group, averaged over a period not exceeding one year, would otherwise exceed the daily intake resulting from continuous exposure to air or water containing one-third the concentration of radioactive materials specified in division (D), Part II, of rule 3701-38-13, OAC.

(F) The provisions of this rule do not apply to disposal of radioactive material in to sanitary sewerage systems, which is governed by rule $3701-38-27$, OAC

Rule 3701-38-17. Orders requiring furnishing of bio-assay services. Where necessary or desirable in order to aid in determining the extent of an incliviclual's exposure to concentrations of radioactive material, the director may issue an order requiring a registrant to make available to the individual appropriate bio-assay services and to furnish a copy of the reports of such service to the director.

Rule 3701-38-18. Surveys.

Lach registrant shall make or cause to be made such surveys as may be necessary for him to comply with rules 3701-38-01 to 3701-38-37, OAC.

Rule 3701-38-19. Personnel monitoring. 10

Each registrant shall supply appropriate personnel monitoring equipment to, and sliall require the use of such equipment by:

(A) Each individual who enters a restricted area under such circum. stances that he receives, or is likely to receive, 11 a dose in any calendar quarter in excess of twenty-five (25) percent of the applicable value specified in division (A) of rule 3701-38-11, OAC.

(B) Each individual under eighteen (18) years of age who enters a restricted area under such circumstances that he receives, or is likely to receive, 11 a dose in any calendar quarter in excess of five (5) percent of the applicable value specified in division (A) of rule 3701 . 38.11, OAC

(C) Each inclividual who enters a high radiation area.

Rule 3701-38-20. Caution signs, labels, and signals.

(A) Cienteral

(1) lixcept as otherwise authorized by the director, the radiation caltition symbol shall be the conventional three-bladed design as

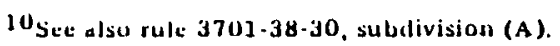

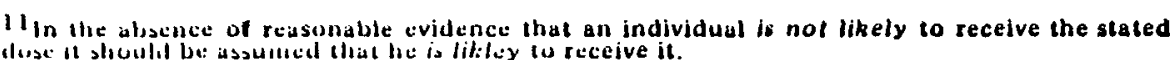

follows with the cross-hatched area to be magenta or purple and the background to be yellow:

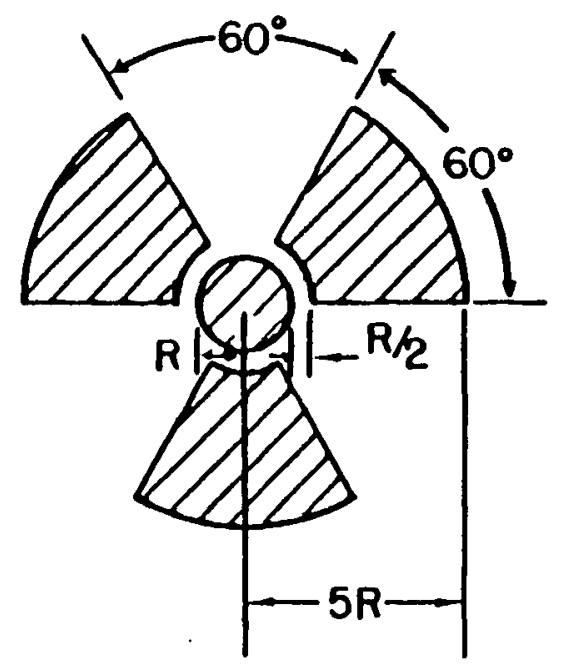

(2) In addition to the contents of signs and labels prescribed in this regulation, a registrant may provide on or near such signs and labels any additional information which may be appropriate in aiding individuals to minimize exposure to radiation.

(B) Radiation areas. 12

Each radiation area shall be conspicuously posted with a sign or signs bearing the radiation caution symbol and the words "CAUTION" and "RADIATION AREA," or "DANGER" and "RADIATION AREA."

(C) High radiation areas. ${ }^{2}$

(1) Each high radiation area shall be conspicuously posted with a sign or signs bearing the radiation caution symbol and the words "CAUTION" and "HIGH RADIATION AREA," or "DANGER" and "HIGH RADIATION AREA."

(2) Each high radiation area shall be equipped with a control device which shall either cause the level of radiation to be reduced below that at which an individual might receive a dose of 100 millirem in one hour upon entry into the area or shall energize a conspicuous visible or audible alarm signal in such manner that the individual entering and the registrant or supervisor of the activity are made aware of the entry. In the case of a high radiation area established for a period of thirty (30) days or less, such control device is not required.

12 See definitions of "radiatlon area" und "high rudiation area" In rule 3701-38-01. 
(D) Airborne radioactivity areas.

(1) $\Lambda \mathrm{s}$ used in this rule "airborne radioactivity area" means (1) any room, enclosure, or operating area in which airborne radioactive material exists in concentrations in excess of the amounts specified in division (D), Part I, Column I of rule 3701-38-13, OAC, or (2) any room, enclosure, or operating area in which airborne radioactive material exists in concentrations which, averaged over the number of hours in any week during which individuals are in the area, exceed twenty-five (25) percent of the amounts specified in division (D), Part I, Column 1, of rule 3701-38-13, OAC.

(2) Bach airborne radioactivity area shall be conspicuously posted with a sign or signs bearing the radiation caution symbol and the words "CAUTION" and "AIRBORNE RADIOACTIVITY AREA," or "DANGER" and "AIRBORNE RADIOACTIVITY AREA."

(E) Additional requirements.

Each area or room in which any radioactive material is used or stored in an amount exceeding ten (10) times the quantity of radioactive material specified in division $(\mathrm{H})$ of this rule shall be conspicuously posted with a sign or signs bearing the radiation caution symbol and the words "CAUTION" and "RADIOACTIVE MATLRIAL," or "DANGER" and "RADIOACTIVE MATERIAL."

(F) Containers.

(1) Each container in which is transported, stored or used radioactive material greater than the quantity of such material specified in division (II) of this rule shall bear a durable, clearly visible label bearing the radiation caution symbol and the words "CAU'ION" and "RADIOACTIVE MATERIAL," or "DAN. GLI" and "RADIOACTIVE MATERIAL."

(2) Nolwithstanding the provision of subdivision (1) of this division, a label shall not be required:

(a) If the concentration of the material in the container does not exceed that specified in division (D), Part I, Column 2, of rule 3701-38-13, OAC.

(b) For laboratory containers, such as beakers, flasks, and test tubes, used transiently in laboratory procedures, when the person using such containers is present.

(3) When containers are used for storage, the labels required in this paralgraph shall state also the quantities and kinds of radioactive materials in the containers and the date of measurement of the quantities.

(G) All devices and equipment capable of producing radiation when 18 operated shall be labeled in a manner which cautions individuals of such fact.

(H) Table of quantities applicable to posting and disposal requirements.

\begin{tabular}{lc}
\hline Radioactive Material & $\begin{array}{c}\text { Quantity } \\
\text { (microcuries) }\end{array}$ \\
\hline Bismuth 210 (Bi 210) & 10 \\
Lead $210(\mathrm{~Pb} \mathrm{210)}$ & 1 \\
Polonium 210 (Po 210) & 0.1 \\
Radium 224 (Ra 224) & 10 \\
Radium 226 (Ra 226) & 0.1 \\
Radium 228 (Ra 228) & 1 \\
Radon 220 (Rn 220) & 1 \\
Radon 222 (Rn 222) & 1 \\
Radioactive material not listed above & 0.1 \\
$\quad$ or unknown mix ture of above & \\
\hline
\end{tabular}

Rule 3701-38-21. Exceptions from posting requirements.

(A) A room or area is not required to be posted with a caution sign because of the presence of a sealed source, provided the radiation level twelve (12) inches from the surface of the source container or housing does not exceed five (5) millirem per hour.

(B) Rooms or other areas in hospitals are not required to be posted with caution signs because of the presence of patients containing radioactive material, provided that there are personnel in attendance who shall take the precautions necessary to prevent the exposure of any individual to radiation or radioactive material in excess of the limits established in rules 3701-38-11 to-3701-38-15, OAC.

(C) Caution signs are not required to be posted at areas or rooms containing radioactive materials for periods of less than eight (8) hours provided that (1) the materials are constantly attended during such periods by an individual who shall take the precautions necessary to prevent the exposure of any individual to radiation or radioactive materials in excess of the limits established in rules $3701-38-11$ to $3701-38-15, \mathrm{OAC}$, and (2) such area or room is subject to the registrant's control.

(D) Radioactive materials packaged and labeled in accordance with the regulations of the United States Department of 'Transportation shall be exempt from the labeling and posting requirements of 
rule $3701-38-20, \mathrm{OAC}$, during shipment provided that the inside containers are labeled in accordance with rule 3701-38-20, OAC.

Rule 3701-38-22. Instruction of personnel; posting of notice to employees.

(A) Each registrant shall inform individuals working in or frequenting any portion of a restricted area of the occurrence of radiation or ricliation: sources in such portions of the restricted area; shall instruct such individuals in the safety problems associated with exposure to such radiation sources and in precautions or procedures to minimize exposure; shall instruct such individuals in the appli(aible: rules for the protection of personnel from exposures to ridiation or radioactive materials; and shall advise such individuals of reports of radiation exposure which those individuals may request pursuant to this rule.

(B) Each registrant shall post a current copy of rules 3701-38-01 to $3701-38-37,0 \mathrm{AC}$, a copy of the acknowledgement of registration, and a copy of operating procedures applicable to work under the registration, conspicuously in a sufficent number of places in every establishment where employees are employed in activities involving. potential exposure to radiation, to permit them to observe a copy on the way to and from their place of employment, or shall keep such documents available for examination upon request.

(C) Each regstrant shall conspicuously post the form, "Notice to Employees," 13 in a sufficient number of places in every establishment to pe-mit employees working in or frequenting any portion of a restricted area to observe a copy on the way to or from their place of enployment. "The form, "Notice to Employees," shall be prescribed and furnished by the director and shall contain in brief form information as to (1) the subjects covered by rules 3701-38-01 to $3701-38-37, O \Lambda C ;(2)$ the employer's responsibility to apply the rules and to post or otherwise make available to employees a copy of the rules: a copy of the acknowledgement of registration, and a copy of operating procedures which apply to employees' work under the rules; (3) the employee's responsibility to become familiar with rules and operating procedures which apply to his work and to olsserve them; (4) the written reports detailing an employee's exposure tc radiation which an employer is required to provide under certain conditions; and, (5) the name and address of the arency which provides inspection of radiation facilities and to which an employec may direct inquiries regarding radiation protection matters.
Rule 3701-38-23. Storage of radiation sources.

Radiation sources shall be secured against unauthorized removal from the place of storage.

Rule 3701-38-24. Leak testing of sealed sources.

(A) Except as authorized by the director pursuant to division (D) of this rule, each sealed source shall be tested for leakage at intervals not to exceed six (6) months. In the absence of a certificate from a transferor that a test has been made within the six (6) month period prior to the transfer or at any time there is reason to suspect that a sealed source may have been damaged, the sealed source shall not be put into use until tested for leakage.

(B)

(B) The leak test shall be capable of detecting the presence of 0.005 microcurie of removable contamination on the sealed source or, in the case of radium, the actual escape of radioactive material at a rate of 0.001 microcurie per twenty-four (24) hours. For sealed sources installed in manufactured devices constructed in such manner as to prevent easy access to the sealed source itself, an acceptable leak test would be to test at the nearest accessible point to the sealed source storage position or other appropriate measuring point by a procedure approved by the director. Records of leak test results shall be kept in units of microcuries and maintained for inspection by the director or his agents.

(C) Any test conducted pursuant to division (A) and (B) of this rule which reveals the presence of 0.005 microcurie or more of removable radioactive material or, in the case of radium, the actual escape of radioactive material at a rate of 0.001 microcuries or more per twenty-four (24) hours shall be considered evidence that the sealed source is leaking. The registrant shall immediately withdraw the sealed source from use and shall cause it to be decontaminated and repaired or to be disposed of in accordance with the applicable provisions of rule $3701-38-25, \mathrm{OAC}$.

(D) The director may, upon application therefor or upon his own initiative, approve a leak test interval longer than six (6) month for sealed sources of a specific type or size or for a specific condition of usage or storage of sealed sources if it has been demonstrated to the satisfaction of the director that such longer leak test interval will not result in undue hazard to public health and safety or property. 
Rule 3701-38-25. General requirements for disposal of radioactive material.

No registrant shall dispose of any radioactive material except:

(A) By transfer to another person, or

(B) As authorized pursuant to rules 3701-38-26, 3701-38-27, 3701$38-28$ or $3701-38-16,0 \wedge C$

Rule 3701-38-26. Method of obtaining approval of proposed disposal proceclures.

Any person may apply to the director for approval of proposed procedures to dispose of radioactive material in a manner not otherwise authorized in rule 3701-38-25, OAC. Each application shall include a description of the radioactive material, including the quantities and kinds of radioactive material and the levels of radioactivity involved, and the proposed manner and conditions of disposal. The application where appropriate, should also include an analysis and evaluation of pertiment information as to the nature of the environment, including topographical, geological, meteorological, and hydrological characteristics; usilge of ground and surface waters in the general area; the nature and location of other potentially affected facilities; and procedures to be observed to minimize the risk of unexpected or hazardous exposures. The director shall not approve any application to receive radioactive material from other persons for disposal on land not owned by the state or federal government.

Rule 3701-38-27. Disposal by release into sanitary sewerage systems. (A) No registrant shall discharge radioactive material into a sanitary sewerage system unless:

(1) It is readily soluble or dispersible in water; and,

(2) The quantity of any radioactive material released into the system by the registrant in any one day does not exceed the larger of subdivisions (a) or (b) of this division:

(a) The culanlity which, if diluted by the average daily quantity of sewage released into the sewer by the registrant, will result in an average concentration not greater than the limits specified in division (D), Part 1, Column 2, of rule 3701-38-13, OAC, or,

(b) 'I'en times the quantity of such material specified in division (11) of rule $3701-38-20$, OAC.

(3) 'Tht: quantity of iny radioactive material released in any one month, if cliluted by the average monthly quantity of water released by the registrant, will not result in an average concentration exceeding the limits specified in division (D), Part I, Column 2, of rule 3701-38-13, OAC;
(4) The gross quantity of radioactive material released into the sewerage system by the registrant does not exceed one curie per year.

(B) Excreta from individuals undergoing medical diagnosis or therapy with radioactive material shall be exempt from any limitations contained in this rule.

Rule 3701-38-28. Disposal by burial in soil.

No registrant shall dispose of radioactive material by burial in soil unless:

(A) The total quantity of radioactive materials buried at any one location and time does not exceed, at the time of burial, 1,000 times the amount specified in division $(\mathrm{H})$ of rule $\mathrm{HE}-38-20, \mathrm{OAC}$;

(B) Burial is at a minimum depth of four (4) feet;

(C) Successive burials are separated by distances of at least six (6) feet and not more than twelve (12) burials are made in any year.

Rule 3701-38-29. Disposal by incineration.

No registrant shall incinerate radioactive material for the purpose of disposal or preparation for disposal except as specifically approved by the director pursuant to rule 3701-38-16 and rule 3701-38-26, OAC.

Rule 3701-38-30. Records of surveys, radiation monitoring, and disposal.

(A) Each registrant shall maintain records showing the radiation exposures of all individuals for whom personnel monitoring is required under rule 3701-38-19, OAC. Such records shall be kept on a form 14 prescribed and furnished by the director in accordance with the instructions contained in that form, or on clear and legible records containing all the information required by that form. The doses entered on the forms or records shall be for periods of time not exceeding one calendar quarter.

(B) Each registrant shall maintain records in the same units used in rules 3701-38-11 to 3701-38-16, OAC, showing the results of surveys required by rule $3701-38-18$ and disposals made under rules 3701-38-26, 3701-38-27, and 3701-38-28, OAC.

(C) Records of individual radiation exposure which must be maintained pursuant to the provisions of division (A) of this rule shall be preserved until December 31,1970, or until a date five (5) years after termination of the individual's employment ne association

14 Form No. 4786 . 
with the registrant, whichever is later, or such other time as the director may determine. Records which must be maintained pursuant to this rule may be maintained in the form of microfilm.

(D) The discontinuance of or curtailment of activities, does not relieve the registrant of responsibility for retaining all records required by this rule. $A$ registrant may, however, request the director to accopt such records. 'The acceptance of the records by the director relieves the registrant of subsequent responsibility only in respect to their preservation as required by this rule.

Rule IIE-38-31. Reports of theft or loss of radiation sources.

Lach registrant shall report by telephone and telegraph to the director the thefl or loss of any radiation source immediately after such occurence becomes known.

Rule IIL-38-32. Notification of incidents.

(d) Jminediate notilication.

Lach iefistrant shall inmediately notify the director by telephone and telegraph of any incident 15 involving any radiation source possessed by him and which may have caused or threatens ito cause:

(1) Exposure to the whole body of any individual to twenty-five (25) rems or more of radiation; exposure of the skin of the whole body of any individual to one hundred fifty (150) rems or more of radiation; or exposure of the feet, ankles, hands, or forcarnis of any individual to three hundred seventy-five (375) rems or more of radiation; or,

(2) The relealse of radioactive material in concentrations which, if averafecl uver a period of twenty-four (24) hours, would exceed five lhousind $(5,000)$ times the limits specified for such ma. Lerials in division (D), Part II, of rule 3701-38-13, OAC; or,

(3) $A$ luss of one working week or more of the operation of any facilities affected; or,

(1) Damatge to property in excess of one hundred thousand dollars $(\$ 100,000)$.

(B) Twenty-four hour notification.

Bach registrant shall within twenty-four (24) hours notify the director by teteplione and telegraph of an incident 15 involving any radiation source possessed by him and which may have caused or threatens to callse:

(1) lixposure of the whole body of any individual to five (5) rems 15 As Uxal in rule 3701-38-32, the term "incident" implies loss of normal control over the

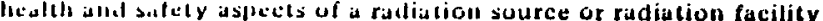

or more of radiation; exposure of the skin of the whole body of any individual to thirty (30) rems or more of radiation; or ex posure of the feet, ankles, hands, or forearms to seventy-five (75) rems or more of radiation; or,

(2) The release of radioactive material in concentrations which, if averaged over a period of twenty-four (24) hours, would exceed five hundred (500) times the limits specified for such materials in division (D), Part II, of rule 3701-38-13, OAC; or,

(3) A loss of one day or more of the operation of any facilities affected; or,

(4) Damage to property in excess of one thousand dollars $(\$ 1,000)$.

(C) Any report filed with the director pursuant to this rule shall be prepared in such a manner that names of individuals who have received exposure to radiation will be stated in a separate part of the report.

Rule 3701-38-33. Report to former employees and others of exposure to radiation.

(A) A registrant, at the request of any individual formerly employed or associated with him, shall furnish to such individual a report of his exposure to radiation as shown in records maintained pursuant to division (A) of rule 3701-38-30, OAC. Such report shall be furnished within thirty $(30)$ days from the time the request is made; shall cover each calendar quarter of the individual's employment or association involving exposure to radiation, or such lesser period as may be requested by the individual. The report shall also include the results of any calculations and analyses of radioactive material deposited in the body of the individual and made pursuant to rule 3701-38-17, OAC. The report shall be in writing and contain the following statement:

"This report is furnished to you under the provisions of the Ohio Public Health Council's rules entitled 'General Radiation Protection Standards', (Chapter 3701-38 of the Ohio Administrative Code). You should preserve this report for future reference."

(B) The individual's request should include appropriate identifying data, such as social security number and dates and locations of em. ployment or association.

Rule 3701-38-34. Reports of exposures, levels, and concentrations in excess of applicable limits.

(A) In addition to any notification required by rule $3701-38.22$, $O A C$, each registrant shall make a report in writing within thirty 
(30) diays to the director of (1) each exposure of an individual to radiation or concentrations of radioactive material in excess of any applicalsle limit as set forth in rules 3701-38-11 to 3701-38-14, $O A C$, or as otherwise approved by the director; (2) any incident for which notification is required by rule $3701-38-32, O A C$; and (3) levels of radiation or concentrations of radioactive material (not involving excessive exposure of any individual) in an unrestricted area in excess of ten (10) times any applicable limit set forth in rules 3701-38-15 and 3701-38-16, OAC, or as otherwise approved by the director. Each report required under this division shall describe the extent of exposure of individuals to radiation or to rudionctive material; levels of radiation and concentrations of radioactive material involved; the cause of the exposure, levels, or concentrations; and corrective steps taken or planned to assure against a recurrence.

(B) In any case where a registrant is required pursuant to this rule to report to the director any exposure of an individual to radiation or to concentrations of radioactive material, the registrant shall, not later than the making of such report to the director, also notify such inclividual of the nature and extent of exposure. Such notice shall contain the following statement:

.'Ihis report is furnished to you under the provisions of the Ohio Public Ileallh Council's rules entitled 'General Radiation Protection Standards.' (Chapter 3701-38 of the Ohio Admininistrative Cude). You should preserve this report for future reference."

(C) Any report filed with the director pursuant to this rule shall be prepared in such a manner that names of individuals who have received exposure to radiation will be stated in a separate part of the report.

Rule 3701-38-35. Notice to employees and others of exposure to radiation.

Lach registrant, at the request of any individual employed or associated with him, shall advise such individual annually of the individual's exposure to radiation as shown in records maintained by the registrant pursuant 10 division $(A)$ of rule 3701-38-30, OAC.

Rule: 3701-38-36. Vacating premises.

liath registrint shall, no less than thirty (30) days before vacating or relinguishing possession or control of premises which may have been contiminated with ratioactive material as a result of his activities, notify the director in writing of intent to vacate.
Rule 3701-38-37. Intrastate transportation of radiouctive materials.

(A) This rule applies to transportation of radioactive material, or the delivery of radioactive material to a carrier for transportation, which is not subject to the rules and regulations of the United States Department of Transportation and other federal agencies having jurisdiction.

(B) No registrant shall transport any radioactive material outside of the confines of his plant, office, hospital, or other authorized location of use, or deliver any radioactive material to a carrier for transportation, unless the registrant complies with all requirements, appropriate to the mode of transportation, relating to the packaging of the radioactive material and to the marketing and labeling of the package and transporting vehicle, of the rules and regulations, as amended, of the United States Department of Transportation (currently 49 CFR Parts 170-189 and 14 CFR Part 103) to the same extent as if the transportation were subject to the rules and regulations of that agency. 


\section{CHAPTER 3701.39}

\section{SPECIAL RADIATION PIROTECTION REQUIREMENTS FOR INDUSIRIAL RADIOGRAPHIC OPERATIONS}

Adopled February 15, 1969; effective July 1, 1969

Aulhority: Section 3701.91, Ohio Revised Code

Rule 3701-39.01. Definitions

T'urms defined in rule 3701-38-01 of the Sanitary Code shall have the sime meaning when used in rules 3701-39-01 to 3701-39-16, OAC, and additionally as used in rules 3701-39-01 to 3701-39-16, OAC.

(A) "Ricliographer" means any individual who performs or who, in attendince at the site where radiation sources are being used, personally supervises industrial radiographic operations and who is responsible to the registrant for assuring compliance with the requirunents of rules 3701-39-01 to 3701-39-16, OAC.

(B) "Radiographer's assistant" means any individual who, under the personal supervision of a radiographer, uses radiation sources, related handling lools, or survey instruments in industrial radiography.

(C) "Radiographic exposure device" means any instrument contain- '. ing a sealed source fastened or contained therein, in which the sealed source or shielding thereof may be moved, or otherwise changed, from shielded to unshielded position for purposes of making a radiographic exposure.

(D) "Industrial radiography" means the examination of the macro. scopic structure of materials by nondestructive methods utilizing radiatlion susurces.

(E) "Sturagu container" means a device in which sealed sources are transported or stored.

(F) "Cibinel radiography" means industrial radiography, using radiation machines, which is conducted in an enclosed, interlocked calbinct, such that the radiation machine will not operate unless all opening's are si:curcly closed, and which cabinet is so shielded that every location on the exterior meets conditions for an unrestricted ar at as specified in rule 3701-38-15, OAC.

(G) "Shiulded room ritdiogriphy"l means industrial radiography, using rictiation machines, which is conducted in an enclosed room, the interior of which is not occupied during radiographic opera-

lCabmet rurloghruphy and shiclded roum radiography using radiation machines are exempt

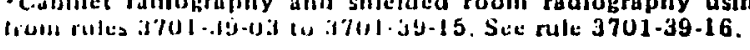

tions, which is so shielded that every location on the exterior meets conditions for an unrestricted area as specified in rule 3701-38-15, $O A C$, and the only access to which is through openings which are interlocked so that the radiation machine will not operate unless all openings are securely closed.

(H) "Field radiography"2 means all industrial radiography using radiation machines other than cabinet radiography and shielded room radiography.

Rule 3701-39-02. Purpose and scope.

Rules 3701-39-01 to 3701-39-16, OAC, establish special radiation safety requirements for persons utilizing radiation sources for industrial radiography. These requirements are in addition to and not in substitution for the requirements of rules 3701-38-01 to 3701-38-37, $\mathrm{OAC}$, and apply to all registrants who use radiation sources not subject to United States Atomic Energy Commission regulation ${ }^{3}$ for industrial radiography. These requirements do not apply to uses of radiation sources in the healing arts.

Rule 3701-39-03. Limits on levels of radiation for radiographic exposure devices and storage containers.

Radiographic exposure devices measuring less than four (4) inches from the sealed source storage position to any exterior surface of the device shall have no radiation level in excess of fifty $(50)$ milliroentgens per hour at six (6) inches from any exterior surface of the device. Radiographic exposure devices measuring a minimum of four (4) inches from the sealed source storage position to any exterior surface of the device, and all storage containers for sealed sources or outer containers for radiographic exposure devices, shall have no radiation level in excess of two hundred (200) milliroentgens per hour at any exterior surface, and ten (10) milliroentgens per hour at one (1) meter from any exterior surface. The radiation levels specified are with the sealed source in the shielded (i.e., "off") position.

Rule 3701-39-05. Locking of sources of radiation.

Each radiation source shall be provided with a lock or outerlocked container designed to prevent unauthorized or accidental production of radiation or removal or exposure of a sealed source and shall be kept locked at all times except when under the direct surveillance of a

2 Field radiography usine radiation machines is exempt from rules 3701-39-03, 3701-39-06. 3701-39-07, and 3701-39-16. See rule 3701-39-16.

${ }^{3}$ Radiation sources not subject to reculation by the U.S. Atomic Energy Commission include $X-r a y$ muchines, radium, and particle acceleratory. 
radiographer or radiographer's assistant, or as may be otherwise authorized pursuant to rule 3701-39-13, OAC. Each storage container likew ise shall be provided with a lock and kept locked when containing sealed sources except when the container is under the direct surveillince of a radiographer or radiographer's assistant.

\section{Rule 3701-39-05. Storage precautions.}

loocked radiographic exposure devices and storage containers shall be physicilly secured to prevent tampering or removal by unauthorized personncl.

Rule 3701-39-06. Radiation survey instruments.

The refistrant shall maintain sufficient calibrated and operable radiation survey instruments to make physical radiation surveys as required by rules 3701-38-18 and 3701-39-15, OAC. Each radiation survey instrument shall be calibrated at intervals not to exceed three (3) months and after each instrument servicing and a record maintained of the latest date of calibration. Instrumentation required by this section shall have a range such that two milliroentgens per hour through one roentgen per hour can be measured.

Rule:1701-39-07. Leak testing, repair, tagging, opening, modification, and replatement of sealed sources.

(d) The replacentent of any sealed source fastened to or contained in a radiographic exposure device and leak testing, repair, tagging, opening, or any other modification of any sealed source shall be performed only by persuns specifically authorized to do so by the directur.

(B) 'The registrant shall provide for the leak testing of sealed sources in accordince with the requirements of rule 3701-38-24, OAC.

(C) A sealced source which is not fastened to or contained in a radiographic exposure device shall have permanently attached to it a durable talg at leust one (1) inch square bearing the prescribed radiacion citution symbol in conventional colors, magenta or purple on a yellow background, and at least the instructions: "Danger - Radioactive Matterial - Do Nolllandle - Notify Civil Authorities if Found."

Rule 3701-39-08. Quarterly inventory.

Bich renistrint shall conduct a quarterly physical inventory to account for all radliation sources received or possessed by him. The records of the inventories shall be maintained for inspection by the director or his inchls ind shall include the quantities and kinds of radioactive material, the location of all radiation sources, and the date of the inventory.

Rule 3701-39-09. Utilization logs.

Each registrant shall maintain current logs, which shall be kept available for inspection by the director or his agents, showing for each radiation source the following information:

(A) A description or make and model number of each radiation source or storage container in which a sealed source is located;

(B) The identity of the radiographer to whom assigned;

(C) Locations where used and dates of use;

(D) The voltage, current, and exposure time for each radiographic exposure employing a radiation machine.

Rule 3701-39-10. Limitations.

(A) No registrant shall permit any person to act as a radiographer as defined in division (A) of rule 3701-39.01, OAC, until such person:

(1) Has been instructed in the subjects outlined in division (C) of this rule and shall have demonstrated understanding thereof;

(2) Has received copies of and instruction in rules 3701-38-01 to 3701-38-37 and 3701-39.01 to 3701-39-16, OAC, and the registrant's operating and emergency procedures, and shall have demonstrated understanding thereof;

(3) Has demonstrated competence to use the radiation source, related handling tools, and survey instruments which will be employed in his assignment.

(B) No registrant shall permit any person to act as a radiographer's assistant as defined in division (B) of rule 3701-39.01, OAC, until such person:

(1) Has received copies of and instruction in the registrant's operating and emergency procedures, and shall have demonstrated understanding thereof;

(2) Has demonstrated competence to use under the personal supervision of the radiographer the radiation sources, related handling tools, and radiation survey instruments which will be employed in his assignment.

(C) Outline of instruction of radiographers.

(1) Fundamentals of radiation sufety

(a) Characteristics of gamma and X-radiation

(b) Units of radiation dose (mrem) and quantity $0^{-}$lioactivity 
(c) Hazards of excessive exposure of radiation

(d) Levels of madiation from radiation sources

(e) Methods of controlling radiation dose

I. Working time

II. IVorking distances

III. Shiciding

(2) Radiation detection instrumentation to be used

(a) Use of radiation survey instruments

1. Operation

II. Cilibration

III. Limitations

(b) Survey techniques

(c) Ust of personnel monitoring equipment

J. Piim badiges

11. l'ocket dosimeters

III. Pocket chambers

(3) Radiographic equipment to be used

(i) Resnote handling equipment

(1) Radiographic exposure devices and sealed sources

(c) Storage containers

(d) Operation and control of X-ray equipment

(4) 'The recpurements of pertinent federal and state regulations

(5) 'The registrint's written operating and emergency procedures

Rule 3701-39-11. Operating and emergency procedures.

'The registrint's operating and emergency procedures shall include instructions in al least the following:

(A) The handling and use of radiation sources to be employed such that no person is likely to be exposed to radiation doses in excess of the limils established in rules 3701-38-11 to 3701-38-16, OAC;

(B) Methods and occasions for conducting radiation surveys;

(c) Methods for controlling access to radiographic areas;

(D) Ne:hods and occasions for locking and securing radiation sources;

(li) Personnel monitoring and the use of personnel monitoring aptuipunent;

(ii) 'T'ransportation to field locations, including packing of radiation sources in the vehicles, posting of vehicles, and control of radiation sources during Liansportation;

(G) Minimizing exposure of persons in the event of an accident;
(H) The procedure for notifying proper persons in the event of an accident;

(I) Maintenance of records.

Rule 3701-39-12. Personnel monitoring control.

(A) No registrant shall permit any person to act as a radiographer or as a radiographer's assistant unless, at all times during radiographic operations, each such person shall wear a film badge and either a pocket dosimeter or pocket chamber. Pocket dosimeters and pocket chambers shall be capable of measuring doses from zero to at least two hundred (200) milliroentgens.

(B) Pocket dosimeters and pocket chambers shall be read and doses recorded daily. A film badge shall be immediately processed if a pocket chamber or pocket dosimeter is discharged beyond its range. The film badge reports received from the film badge processor and records of pocket dosimeter and pocket chamber readings shall be maintained for inspection by the director or his agents.

Rule 3701-39-13. Security.

During each radiographic operation, the radiographer or radiographer's assistant shall maintain direct surveillance of the operation to protect against unauthorized entry into a high radiation area, as defined in rule $3701-38.01, O A C$, except (1) where the high radiation area is equipped with a control device or an alarm system as described in subdivision $(C)(2)$ of rule $3701-38-20, O A C$, or $(2)$ where the high radiation area is locked to protect against unauthorized or accidental entry.

Rule 3701-39-14. Posting.

Notwithstanding any provisions in division (C) of rule 3701-38-21, $\mathrm{OAC}$, areas in which radiography is being performed shall be conspicuously posted as required by division (B) of rule 3701-38-20, OAC, and subdivision $(C)(1)$ of 3701-38-20, OAC.

Rule 3701-39-15. Radiation surveys and survey records.

(A) No radiographic operation shall be conducted unless calibrated and operable radiation survey instrumentation, as decribed in rule 3701-39-06, 0AC, is available and used at each site where radiographic exposures are made.

(B) A physical radiation survey shall be made after each radiographic exposure utilizing radiographic exposure devices or sealed sources of radioactive material to determine that the sealed source has been returned to its shielded condition. 
(C) A physical ridiation survey shall be made to determine that each seilled source is in its shiclded condition prior to securing the radiogrilphic exposure device or storage container as specified in rule $3701-39-04,0 \wedge C$.

(D) Records shall be: kept of the surveys required by division (C) of this rule and maintained for inspection by the director or his agents.

Rule 3701-39-16. Special requirements for radiography employing radiallion machines.

(A) Cialsinet radiography.

Calinet radiography shall be exempt from the requirements of rules $3701-39-03$ to $3701-39-15,0 A C$; however, no registrant shall permit any indiviclual to operate a cabinet radiography unit until such individual has received a copy of, and instruction in, and demonstritud an understanding of operating procedures for the unit, and has dimonstrated competence in its use.

(B) Shielded room radiography.

Shiclded room radiography shall be exempt from the requirements of rules 3701-39-03 to 3701-39-15, OAC; however:

(1) No registrint shall permit any individual to operate a radiation michine for shiclded room radiography until such individual has' received a copy of, and instruction in, and demonstrated an understanding of operating procedures for the unit, and has demonstrated competence in its use;

(2) Lach registrant shall supply appropriate personnel monitoring equipmenl to, and shall require the use of such equipment by, cvery individual who operates, who makes "set-ups", or who performs maintenance on a radiation machine for shielded room ratliography.

(C) Ficld radiography.

Fich racliography shall be exempt from rules 3701-39-03, 3701 .

319-(15, 3701-39)-07 and 3701-39-15, OAC; however:

(1.) A physicial madiation survey shall be conducted to determine thit the radiation machine is "off" prior to each entry into the ratiographic exposure area. Such surveys shall be made with a racliation measuring instrument capable of measuring radiation of the encrgies and at the dose rates to be encountered, which is in rood working order, and which has been properly calibratad within the preceding three months or following the last instrument servicing, whichever is later. Survey results and records of houmlary locations shall be maintained and kept available for insprections.

(2) Mubilu: or portible radiation machines shall be physically secured to prevent removal by unauthorized personnel.

\section{CHAPTER 3701-40}

\section{SPECIAL RADIATION PROTECTION REQUIREMENTS FOR THE USE OF RADIATION IN THE HEALING ARTS Adopted February 15, 1969; effective July 1, 1969}

Authority: Section 3701-91, Ohio Revised Code

Rule 3701-40-01. Definitions.

Terms defined in rule 3701-38-01, OAC, shall have the same meaning when used in rules 3701-40-01 to $3701-40-13$, inclusive, $O A C$, and additionally, as used in rules $3701-40-01$ to $3701-40-13$, OAC.

(A) "Aluminum equivalent" means the thickness of aluminum affording the same attenuation, under specified conditions, as the material in question.

(B) "Dead-man switch" means a switch so constructed that a circuitclosing contact can only be maintained by continuous pressure by the operator.

(C) "Diagnostic-type tube housing" means an X-ray tube housing so constructed that the leakage radiation at a distance of one (1) meter from the target cannot exceed one hundred (100) milliroentgens in one (1) hour when the tube is operated at any of its specified ratings.

(D) "Filter" means material placed in the useful beam to absorb preferentially the less penetrating radiations.

(E) "Half-value layer" (hvl) means the thickness of an absorber required to reduce a beam of radiation to one-half its incident exposure rate.

(F) "Inherent filtration" means the filtration in the useful beam due to the window of the $X$-ray tube and any permanent tube enclosure.

(G) "Interlock" means a device for precluding access to an area of radiation hazard either by preventing entry or by automatically removing the hazard.

(H) "Kilovolts peak" $(\mathrm{kVp})$ means the crest value of kilovolts of the potential of a pulsating potential generator. When only one-half of the wave is used, the value refers to the useful half of the wave.

(I) "Lead equivalent" means the thickness of lead affording the same attenuation, under specified conditions, as the material in question.

(J) "Leakage radiation" means all radiation coming

m within the 
tulu: housing except the useful beam.

(K) "Primary protective barrier" means a barrier sufficient to attenllate the useful beam to the required degree.

(l.) "I rotective atpron" means an apron made of attenuating materials, used to reduce radiation exposure.

(M) "Protective barrier" means a barrier of attenuating materials used to reduce radiation exposure.

(N) "l'ro'sctive glove" means a glove made of attenuating maLerialis used to reduce radiation exposure.

(O) "Siatlered radiation" means radiation that, during passage through matler, has been devialed in direction.

(1) "Stccondary protective barrier" means a barrier sufficient to attemuat: stray radiation to the required degree.

(Q) "Shutter" means a device, generally of lead, fixed to an X-ray tube housing to intercept the useful beam.

(R) "Straty racliation" means radiation not serving any useful purpose incl includes loakage and scattered radiation.

(S) "lherapeutic-type tube housing" means an X-ray tube housing so cunstracted that the leakage radiation at a distance of one (1) meter from the target cannol exceed one (1) roentgen in one (1) hour; and at a distance of five (5) centimeters from any point on the surfice of the housing accessible to the patient cannot exceed chirty $(30)$ roentgens in one (1) hour when the tube is operated at any of its specified ratings.

(T) "Usclul beam" means that part of the radiation which passes ihrowgh lihe: window, aperture, cone, or other collimating device ol the: l.ube housing.

Rule 370]-40-02. Purpose and scope.

Riules :370]-30-0.1 to $3701-40-13, O A C$, establish specific radiation protection reguirements for the usc of radiation in the healing arts by a prictitionar licensisd by law to use or direct the use of radiation iil the course of his professional practice. These requirements are in adclition $l(1$, and $n o l$ in sulistilution for, the requirements of rules $3701-38 .(1) 10.3701-38-37,0 \wedge \mathrm{C}$, and apply to all persons engaged in the lotaling ants who possess, use, or transfer radiation sources not sulijoc:t to regulation by the United States Atomic Energy Commission.1

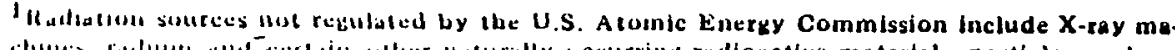

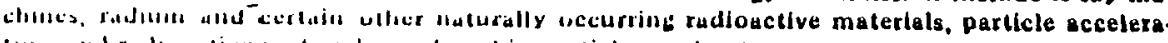

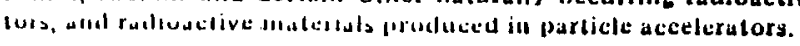

36
Rule 3701-40-03. General X-ray safety provisions.

(A) The director may waive compliance with specific requirements of rules 3701-40-01 to 3701-40-13, OAC, by an existing machine or installation if (1) such compliance would require replacement or substantial modification of the machine or installation and (2) the registrant demonstrates, to the director's satisfaction, achievement through other means of radiation protection equivalent to that required by the rules.

(B) No person shall make, sell, lease, transfer, lend, or install X-ray equipment or the supplies used in connection with such equipment unless such supplies and equipment, when properly placed in operation and properly used, will meet the requirements of rules 3701 $40-01$ to $3701-40-12$, OAC.

(C) Use.

(1) The registrant shall be responsible for assuring that all requirements of rules 3701-40-01 to 3701-40-12, OAC, are met.

(2) The registrant shall assure that all $X$-ray equipment under his control is operated only by individuals adequately instructed in safe operating procedures and competent in safe use of the equipment.

(3) The registrant shall provide safety rules to each individual operating X-ray equipment under his control, including any restrictions of the operating technique required for the safe operation of the particular X-ray apparatus, and require that the operator demonstrate familiarity with these rules.

(D) Shielding.

Each installation shall be provided with such primary protective barriers and/or secondary protective barriers as are necessary to assure compliance with rules 3701-38-11,3701-38-14, and 3701. $38-15, O A C$.

Rule 3701-40-04. Prohibited use.

No registrant shall operate or permit the operation of X-ray equipment unless the equipment and installation meet the applicable requirements of rules $3701-40-01$ to $3701-40-12$, OAC.

\section{Rule 3701-40-05. Fluoroscopic X-ray installations.}

(A) Equipment.

(1) The tube housing shall be a diagnostic-type tube housing.

(2) The target-to-panel or target-to-table top distance of equipment installed or re-installed after the effective date of this rule shall not be less than twelve (12) inches. 
(3) The totial filtrition permanently in the useful beam shall not be less than 2.5 millineters aluminum equivalent. This requirement may he assumeal to have been met if the half-value layer is not less than 2.5 millimelers aluminum at normal operating voltages.

(4) 'l'he ecfuipment shall be so constructed that the entire crosssection of the useful beam is attenuated by a primary barrier. 'l'his hatrier is ustually the viewing device, either a conventional fluorosicopic screen or an image intensification mechanism.

(5) lior equipment installed or re-installed after the effective date of this rule the required lead equivalent of the primary barrier shall not be less than 1.5 millimeters for equipment operating up to $100 \mathrm{kV}$, shiall not be less than 1.8 millimeters for equipment operating from 101 to $125 \mathrm{kVp}$, or shall not be less than 2.0 millimeters for equipment operating from 126 to $150 \mathrm{kVp}$. For conventional fluoroscopes these requirements may be assumed to have been met if the exposure rate measured at the viewing surfatce of the fluorescent screen does not exceed fifty (50) milliroentgens per hour with the screen in the primary beam of the fluoruscope without a patient, under normal operating conditions.

(6) Collimators shall be provided to restrict the size of the useful beam to less than the area of the barrier. For conventional fluorosicopes this requirement is met if, when the adjustable diiphringm is opened to its fullest extent, an unilluminated margin is left on the fluorescent screen with the screen centered in the beim it a distance of fourteen (14) inches from the panel or table: top).

(7) 'The tube mounting and the barrier shall be so linked together, that, uncler conditions of normal use, the barrier always intercepts the useful beam.

(8) Cullimators ind adljustable diaphragms or shutters to restrict the size of the uscful beam shall provide a minimum of $\mathbf{2 . 0}$ millimelers loacl-ecpuivalent protection for equipment operating up to $10 \mathrm{kVp}, 2.1$ millimeters for equipment operating from 101 to $123 k V_{1}$, or 2.7 millimeters for equipment operating from 126 to $150 \mathrm{kVp}$

(9) 'The "xposure swilch shall be of the dead-man type.

(10) A matnual-resel, cumulative timing device shall be used which will rither inclicate elilpsed irradiation time by an audible signal or turn off tha apparatus when the total exposure exceeds a predetermincel limit, not to exceed five (5) minutes, in one or a sories of expessures.

111) lior rouliul fluoroscopy, the exposure rate measured at the piallel or table tops should be as low as practicable but shall not excerd ten (10) roentgens per minute.
(12) Mobile fluoroscopic equipment shall meet the requirements of this rule where applicable, except that:

(a) In the absence of a table top, a cone or spacer frame shall limit the target-to-skin distance to not less than twelve (12) inches.

(b) Image intensification shall always be provided. Conventional fluoroscopic screens shall not be used.

(c) It shall be impossible to operate a machine when the collimating cone or diaphragm is not in place.

(d) The exposure rate measured at the minimum target-to-skin distance should be as low as practicable but shall not exceed ten (10) roentgens per minute.

(B) Structural shielding.

Ordinarily, only secondary barriers are necessary except for combined fluoroscopic-radiographic installations.

Rule 3701-40-06. Radiographic installations other than dental and veterinary medicine.

(A) Equipment.

(1) The tube housing shall be a diagnostic-type tube housing.

(2) Diaphragms, cones or adjustable collimators2 capable of restricting the beam to the area of clinical interest shall be provided and shall provide the same degree of protection as is required in the housing.

(3) Except when contraindicated for a particular medical purpose, the aluminum equivalent of the total filtration in the useful beam shall not be less than 0.5 millimeters for equipment operating below $50 \mathrm{kVp}$, shall not be less than 1.5 millimeters for equipment operating from $50 \mathrm{kVp}$ to $70 \mathrm{kVp}$, and shall not be less than 2.5 millimeters for equipment operating above $70 \mathrm{kVp}$. These requirements may be assumed to have been met if the half-value layer for the useful beam, in millimeters of aluminum, is not less than 0.6 at $50 \mathrm{kVp}$, is not less than 1.6 at $70 \mathrm{kVp}$, or is not less than 2.6 at $90 \mathrm{kVp}$.

(4) A device shall be provided to terminate the exposure after a preset time or exposure.

(5) A dead-man type of exposure switch shall be so arranged that it cannot be conveniently operated outside a shielded area. Exposure switches for "spot film" devices used in conjunction with fluoroscopic tables are excepted from this shielding requirement.

2The departunent of health strongly recommends the use of a modern adjustable collimator employins a beam-defining llght except for X-ray inuchines used for angle purpose with fixed tarbet-to-film distance and fixed film size, e.t. chest radiographs only. in whach case a permanently installed dlaphragm or cone of the proper size would be pretera 
(13) Structural shitelding.

(1) All will, liour, and ceiling areas exposed to the useful beam shall have primatry barriers.3 l'rimary barriers in walls shall r.xtrid to a minimum height of eighty-four (84) inches above the floor.

(2) Sieconclary barriers shall be provided in all wall, floor, and ceil. inf intas nut having primary barriers or where the primary barrier requirements are lower than the secondary barrier requirements. ${ }^{3}$

(3) 'lle: operalor's stition at the control shall be behind a protective latmicer, cither in a separate room, in a protected booth, or behind a shicld which will intercept the useful beam and any radialion which hats been scattered only once.

(.1) A window of leitl-equivalent glass equal to that required by the adjalcent barrier or a mirror system shall be provided large enough allil so pliked that the operator can see the patient without having to leave she protected area during exposure.

(C) Operating procedures.

(1) No indiviclual occulpationally exposed to radiation shall be permilled to hold pationts during exposures except during emergencicts, nor shall any individual be regularly used for this service, If a pittient niust be held by an individual, that incividual shall be protected with appropriate shiclding devices such as protective gloves: and iljron and he shall be so positioned that no part of his body, except hands and arms, will be struck by the useful beam.

(2) () nly inclividuals required for the radiographic procedure shall b. in the: radiogritulic: room during exposure; and, except for the pitticnt, all such persons shall be equipped with appropriate protective alevices

(3) 'l'h: useful lxam shall be restricted to the area of clinical interest. 1

Rule $\$ 7701-10-07$. Special requirements for mobile diagnostic radiographic: equipment.

(:) licpuipune:nt.

(1) All requirtments of rule 3701-40-06, OAC, apply except subdivision (A)(5) w rule 3701-40-06, OAC.

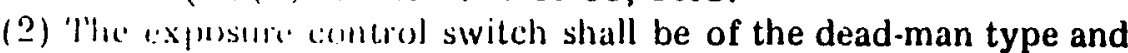

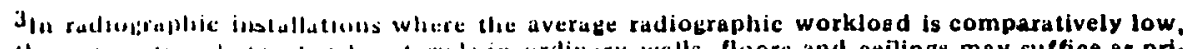

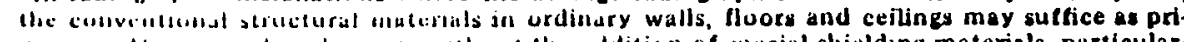

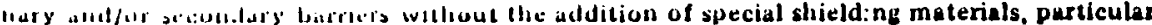

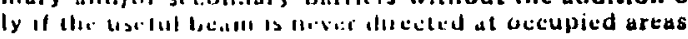

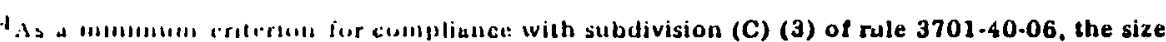

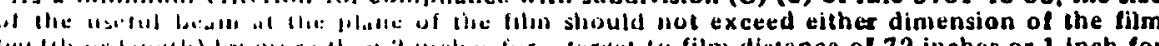

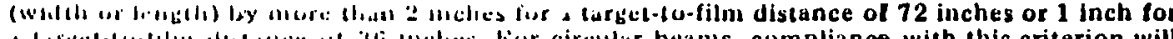

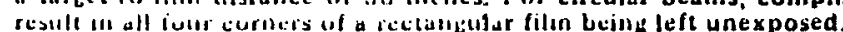

shall be so arranged that the operator can stand at least six (6) feet from the patient and well away from the useful beam.

(B) Structural shielding.

When a mobile unit is used routinely in one location, it shall be considered a fixed installation subject to the shielding requirements specified in division (D) of rule 3701-40-03 and division (B) of rule 3701-40-06, OAC.

(C) Operating procedures.

(1) All provisions of division (C) of rule 3701-40-06, OAC, apply except subdivision (C) (2).

(2) The target-to-skin distance shall not be less than twelve (12) inches.

(3) Personnel monitoring shall be required for all individuals operating mobile $\mathrm{X}$-ray equipment.

Rule 3701-40-08. Special requirements for chest photofluorographic installations.

(A) Equipment.

(1) All provisions of division (A) of regulation 3701-40-06, OAC, apply.

(2) A collimator shall restrict the useful beam to the area of the photofluorographic screen.

(B) Structural shielding.

(1) All provisions of division (D) of rule 3701-40-03 and division (B) of rule 3701-40-06, OAC, apply.

(C) Operating procedures.

(1) All provisions of division (C) of rule 3701-40-06, OAC, apply except subdivision (C) (2).

(2) All individuals except the patient being examined shall be in shielded positions during exposures.

(3) Personnel monitoring shall be required for all individuals operating the equipment.

Rule 3701-40-09. Dental radiographic installations.

(A) Equipment.

(1) The tube housing shall be a diagnostic-type tube housing.

(2) Diaphragms or cones shall be used for collimating the useful beam and shall provide the same degree of protection as the housing. The diameter of the useful beam at the cone tip shall not be more than three (3) inches for in tra-oral radiography.

(3) A cone or spacer frame shall provide a target-to-skin distance of 
not less than seven (7) inches with apparatus operating above filly $(50) k V_{p}$ or four (4) inches with apparatus operating at fifity $(50) \mathrm{kV}$ p or below.

(4) 'The aluminum equivalent of the total filtration in the useful beim shall not be less than 0.5 millimeters for equipment operating lielow filly $(50) k V p$, shall not be less than 1.5 millimeters for equipment operating from fifty (50) $\mathrm{kVp}$ to seventy (70) $k V p$, ind shill not be less than 2.5 millimeters for equipment oprerating, allove seventy (70) $\mathrm{kVp}$. These requirements may be assumed to have been met if the half-value layer for the useful beitm, in millimeters of aluminum, is not less than 0.6 at fifty (50) $k V_{p}$, is nol less than 1.6 at seventy (70) $\mathrm{kVp}$, or is not less Lhanl $2 .(j$ at nincly (90) $\mathrm{kVp}$.

(5) $A$ device shall be provided to terminate the exposure after a presel time or exposure.

(6) 'The exposure control switch shall be of the dead-man type.

(7) Eilch installation shall be provided with a protective barrier for the operator or shall be so arranged that the operator can stind al least six (6) feet from the patient and well away from the useful beam.

(B) Structural shielding.

(1) Jentitl rooms containing $\mathrm{X}$-ray machines shall be provided with primary barriers at all areas struct by the useful beam. Consideration maly be griven to the attenuation provided by the patient.

(2) When dental $X$-ray units are installed in adjacent rooms or areas, prolective harriers shall be provided between the room sor areas. In many citses structural materials of ordinary walls suffice as a protective harricer without addition of special shielding material.

(C) Operating procedures.

(1) Neither the dentist nor his assistant shall be permitted to hold pittintints or films cluring exposure, nor shall any individual be refillarly used for this service.

(2) !) ring eitch exposure, the operator shall stand at least six (6) feret from the patient or behind a protective barrier.

(3) Only the pittient shall be in the useful beam.

(-1) Neither the tulse housing nor the pointer cone shall be handheld dering exposure.

(5) Siluruscopy shall not be used in dental examinations.

Zule $3701-40-10$. 'Therapeutic X-ray installations.

A) liquipmint.

(1) 'Th" (ube housing shall be a therapeutic-type tube housing.
(2) Permanent diaphragms or cones used for collimating the useful beam shall afford the same degree of protection as the tube housing. Adjustable or removable beam-defining diaphragms or cones shall transmit not more than five (5) percent of the useful beam obtained at the maximum kilovoltage and with maximum treatment filter.

(3) Filters shall be secured in place to prevent them from dropping out during treatment. The filter slot shall be so constructed that the radiation escaping through it does not exceed one (1) roentgen per hour at one (1) meter, or, if the radiation from the slot is accessible to the patient, thirty $(30)$ roentgens per hour at five (5) centimeters from the external opening.

(4) The X-ray tube shall be so mounted that it cannot turn or slide with respect to the aperture.

(5) Means shall be provided to immobilize the tube housing during stationary portal treatment.

(6) A timer shall be provided to terminate the exposure after a preset time regardless of what other exposure limiting devices are present.

(7) Equipment utilizing shutters to control the useful beam shall have a shutter position indicator on the control.

(8) There shall be on the control panel an easily discernible indicator which will give positive information as to whether or not the $\mathrm{X}$-ray tube is energized.

(B) Structural shielding.

(1) All wall, floor and ceiling areas that can be struck by the useful beam, plus a border of one foot, shall be provided with primary protective barriers.

(2) All wall, floor, and ceiling areas that, because of restrictions in the orientation of the useful beam, cannot be struck by the useful beam shall be provided with secondary barriers.

(3) With equipment operating above one hundred twenty-five (125) $k V p$, the required barriers shall be an integral part of the building.

(4) With equipment operating above one hundred fifty (150) $\mathrm{kVp}$, the control station shall be within a protective booth or outside the treatment room.

(5) Interlocks shall be provided so that when any door of the treatment room is opened either the machine will shut-off automatically or the radiation level within the room will be reduced to an average of not more than two (2) milliroentgens per hour and a maximum of ten (10) milliroentgens per hour at a distance of one (1) meter in any direction from the target. After such shutoff or reduction in output it shall be possible to restore the machine to full operation only from the control pant 
(6) Provision shall be macle to permit continuous observation of palliente during irracliation.

(7) Windows, mirror systems, or closed-circuit television viewing arems lised lor olserving the patient shall be so located that 111. oprerator maty see the patient and the control panel from the sillle position

(C) Oprematiog procedures.

(1) All mew installations, and existing installations not previously surveyed, shill hatve a protection survey made by, or under the directions of, at qualified expert. 'I'his shall also be done after any change in the installation which might produce a radiation hazard. 'l'h:: explert shall report his findings in writing to the person in chilrge of the instilliation and a copy of the report shall be kispl available for inspection by the director or his agents.

(2) I'lie iastillation shall be operated in compliance with any limititions inclicated by the protection survey.

(3) 'The o.14)ut of each lherapeutic $X$-ray unit shall be calibrated by, or under the direction of, a qualified expert. The calibration sliall be repeated after each $X$-ray tube replacement and after any chang: or veplacement of the X-ray generating equipment which esuld effect a change in the X-ray output. Check caliliritims shall be micle at least once a year thereafter. Records of the culibration results shall be maintained for inspection by thre direcelor or his agents.

(1) No inc iviclual who works with radiation, unless he is the patient, shall he in the treatment room during exposure. No other individ. mal sha!l he thert: except when it is clinically necessary. If an inclividial is required to be in the treatment room with the pillichl cluring axposure, he shall be protected as much as possible fiom statlereal raliation, and shall not be in the useful beam.

Rule 3701-(i)-11. Special requirements for X-ray therapy equipment operated al polentials of sixty (60) KV and below.

(A) Bifuipumellt.

(1) All provisions of division (A) of rule 3701-40-10, OAC, apply, excepl, for ecquipment used for "contact therapy," subdivision (.) (1), in which instince the leakage radiation at the surface of the: tulue housing shall not exceed 0.1 roentgen per hour.

(2) 'lline shall b. un the control panel some easily discernible llevice: which will give positive information as to whether or not

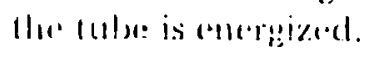

(3) Antunialit: timlers shatl he provided which will permit accurate mistlting and determination of exposures as short as one second.
(B) Structural shielding

All provisions of division (B) of rule 3701-40-10, OAC, apply except that portable shields may be used as protective barriers and interlocks are not required.

(C) Operating procedures.

(1) All provisions of division (C) of rule 3701-40-10, OAC, apply except that the operator and other individuals may be permitted in the treatment room during exposure provided that protective aprons having a lead equivalent of at least 0.25 millimeter are worn or protective barriers are utilized.

(2) In the therapeutic application of apparatus constructed with beryllium or other low-filtration windows the registrant shall insure that the unfiltered radiation reaches only the part intended and that the useful beam is blocked at all times except when actually being used.

(3) Machines having an output of more than one thousand $(1,000)$ roentgens per minute at any accessible place shall not be left unattended without the power being shut-off at the primary disconnecting means.

(4) If the tube is hand-held during irradiation, the operator shall wear protective gloves.

Rule 3701-40-12. Veterinary medicine radiographic installations.

(A) Equipment.

(1) The tube housing shall be a diagnostic-type tube housing.

(2) Diaphragms, cones or adjustable collimators shall be provided for restricting the useful beam to the area of clinical interest and shall provide the same degree of protection as is required of the housing.

(3) Except when contraindicated for a particular radiographic purpose, the total filtration permanently in the useful beam shall not be less than 1.5 millimeters aluminum-equivalent for equipment operating up to seventy (70) $\mathrm{kVp}$ and 2.0 millimeters aluminum-equivalent for machines operating in excess of seventy (70) $\mathrm{kVp}$. These requirements may be assumed to have been met if the half-value layer for the useful beam, in millimeters of aluminum, is not less than 1.4 at sixty $(60) \mathrm{kVp}$, is not less than 1.6 at seventy $(70) \mathrm{kVp}$, and is not less than 2.1 at eighty $(80) \mathrm{kVp}$.

(4) A device shall be provided to terminate the exposure after a preset time or exposure.

(5) A dead-man type of exposure switch shall be provided, together with an electrical cord of sufficient length so that the operator can stand out of the useful beam and at least six (6) feet from the animal during all X-ray exposures. 
(B) Structural shielding.

All will, eeiling, and floor areas shall be equivalent to or shall be provided with applicable protective barriers as required in division (B) of rule: 37111-10-01i, OAC.

(C) Operitling procedures.

(1) 'Tlic operator shall stand well away from the tube housing and the allimal during tadlographic exposures. Provisions shall be mikde so that the operator will not be required to stand in the useful be:ams. Hinnd-held fluoroscopic screen shall not be used. 'lhe luhe housing shall not be held by the operator. No individual other than the operator shall be in the X-ray room while exposures are being matce unless such individual's assistance is requirecl.

(2) II itly alpplicition in which the operator or other assisting individual is not located behind a protective barrier, clothing consisting of a prolcelive apron having a lead-equivalent of not less than 0.5 millimeter shall be worn by the operator and any other inclividuals in the room during exposures.

(3) No individuit shall be regularly employed to hold or support animils or hold lilm during radiation exposures. Occupationally exposed inclividuats shall not perform this service except in cases in which no other method is available. Any individual holding or supporting in inimal during radiation exposure shall wear proleclive gloves and alpron having a lead-equivalent of not less than 0.5 millimeler ind shall be so positioned that no part of his huly, ixceph hands and arms, will be struck by the useful beam.

Rule 3701-10-13. Interstitial, intracavitary and superficial applications of ralliation from staled sources.

(A) Aecoumlatbility, storilge and transit.

(1) lixcept ats otherwise specifically authorized by the director, eitch mistrant shall provide accountability of sealed sources and

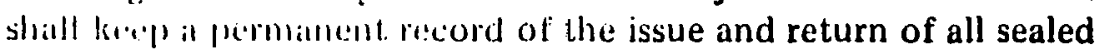
sultrees.

(2) IV/1r.1 not in use, st:illed sources and applicators containing sealed sourcess shit! be kept in a protective enclosure of such material and wall thickness als maty be necessary to assure compliance with rules :3701-38-11, $3701-38-14$, and 3701-38-15, OAC. ${ }^{5}$

(B) 'Pesting seallel sources for leakage and contamination.

(1) 'The: ribgistrall silall provide for the leak testing of sealed sources in actordiance: with rule $3701-38-24,0$ C.

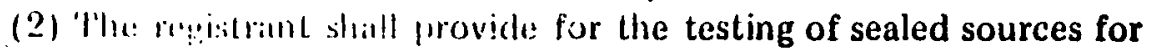
(omtamination prior to initial use.

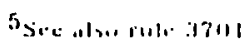

mal divistons (1:) and (F) of rule 370 1-38-20.

\section{CHAPTER 3701.41}

\section{PREVENTING THE USE OF FLUOROSCOPES FOR SHOE FITTING PURPOSES}

Adopted April 12, 1958; effective May 1, 1958

Authority: Section 3701.13, Ohio Revised Code

Rule 3701-41.01.

On and after May 1, 1958, the use of fluoroscopes for shoe fitting purposes, other than by a physician or chiropodist, is hereby prohibited.

\section{Rule 3701-41-02.}

The sale, lease, loan, donation, or other transfer of shoe fitting fluroscope equipment, used prior to the effective date of this regulation except to physicians, chiropodists, hospitals, medical and dental schools, accredited colleges and universities, and manufacturers, wholesalers, and retailers of such equipment, is hereby prohibited. 


\section{P'AR'I II}

\section{RADIATION PRO'TLCTION STA'TUTES,} OHIO lilivisit) COIDE

Sections 3701.90 to 3701.98 , inclusive, and amended section 3701.99 , of the Berviserl Code, relative to radiation protection and to the functions, powers, and dulies of the department of health relative to the prevention and prohibition of improper radiation.1

Section 3701.90 Definitions.

As usell in sections 3701.90 to 3701.98 , inclusive, of the Revised Code: (A) "lialliation" means farmma rays and X-rays, alpha and beta particles, high-speed electrons, neutrons, protons, and other atomic or uluclear partucles or riys, but does not mean sound or radio waves, or visihle, in [rared, or ultraviolet light.

(B) "Rikdivatclive malerial" means any material, solid, liquid, or gas, that emits radiation spontaneously.

(C) "Rinliation device" means any device that produces radiations when the associalted control devices are operated.

(I) "Rauliation source" means a radiation device or radioactive material.

(ii) "Improper rildiation" means gamma rays, X-rays, alpha and beta pirticlass, high-speced ulectrons, neutrons, protons, and other nuclear particless or libys in such quantity and under such circumstances as mity impaitr lhe: heallh of the people, as determined from time to time: by regulations adopted by the public health council.

(F) "Pirson" mealns the state, any municipal corporation, political subdivision, fulslic: or private corporation, individual, partnership, or ofhere intily.

Section 3701.91 Rergulations.

The pulsic heilth comncil, subject to sections 119.01 to 119.13 , inclusive, of the lieviserl Cocle, maty adopt regulations as may be necessary to identify, prohibit, and prevent improper radiation, including the registrittion of persons with the director, who produce, use, store, or dispose of ridliation sources. In adopting such regulations, the public health commeil maly exempt certain sources of radiation which do not present a pulalie health hazarl, and shall not formulate more restrictive: statmlinds thiu those estithlished by the federal government. In

1Fited with the sed ret.ury of Stute, August 5, 1959: effective November 4, 1959. .18 formulating such regulations, due consideration shall be given to standards recommended by nationally recognized authorities in the field of radiation protection.

\section{Section 3701.92 Power and duties of director.}

The director of health:

(A) Shall administer and enforce sections 3701.90 to 3701.98 , inclusive, of the Revised Code and regulations promulgated pursuant to such sections;

(B) Shall develop comprehensive policies and programs for the evaluation and determination of improper radiation associated with the production, use, storage, or disposal of radiation sources;

(C) May advise, consult, and cooperate with other agencies of the state, the federal government, other states, and interstate agencies, and with affected groups, political subdivisions, and industries in furtherance of the purposes of sections 3701.90 to 3701.98 , inclusive, of the Revised Code.

(D) May accept and administer grants from the federal government and from other sources, public or private, for carrying out any of its functions. All such moneys shall be deposited in the state treasury, and kept by the treasurer of state in a separate fund subject to the lawful orders of the director;

(E) May encourage, participate in, or conduct studies, investigations, training, research, and demonstrations, relating to the control of improper radiation, the measurement of radiation, the effects on health of exposure to radiation, and related problems as he may deem necessary or advisable;

(F) May review plans and specifications for the control of improper radiation from radiation sources submitted pursuant to regulations adopted by the public health council;

(H) Shall register persons who produce, use, store, or dispose of radiation sources in accordance with regulations adopted by the public health council;

(I) May inspect radiation sources, their shielding and surroundings for the determination of any possible improper radiation; and provide the owner, user, or operator with a report of any known or suspected deficiencies;

(J) Shall require the maintenance of records pertaining to the radiation source and such records may be examined by any authorized 
represtintitive of the director pursuant to regulations adopted by the puhlic: heallh conncil subject to sections 119.01 to 119.13 , inclusive, of the Revisid Code;

(K) Mily issue, modify, or revolse orders, subject to section 3701.97 of the licevised Cocle, (1) prohibiting or preventing improper radia(ion; (2) recpiring the modilication or alteration of radiation sources to prevent, control, or alsite improper radiation; (3) prohibiting or aloating the dischitrs: of radiouctive material or waste into the ground, air, or waters of the state;

(1.) Miay excrcise all incidental powers necessary to carry out the purposic's of sections 3701.90 to 3701.98 , inclusive, of the Revised Code.

Section 3701.93 Radiation advisory council; duties.

(A) Ilue director of health, subject to the approval of the governor, shall alploint a moliation advisory council which shall consist of the following::

(1) (1). individual of recognized ability in the field of radiation plis'sics;

12) Golle inclividlail wilh experience in radiation protection;

(i) (I) individlual of recognized ability in the field of medicine with experinence in radiation problems;

(1) Che: incliviclual of recognized ability in the field of atomic alling:

(5) (111. individual of recognized ability in the field of industrial

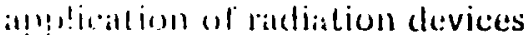

Of lliost: lirst ilpuinted, one shall serve for one year, one shall sitve for livo ycills, onl: shall serve for three years, one shall serve lor font yeatrs, and one shall serve for five years, as designated by the directur at the time of appointment. Thereafter, the term of oflice for line live individuals shall be for five years. If a vacancy acturs, it sucissis shall be? alpointed for the unexpired term. Mem. hers if the ritliatirm advisory council shall serve without compensition bul shail be reimbursed for actual expenses incurred in the preformtance: of their oflicial cluties.

(B) 'I!n ridtiation iulvisory council shall:

(1) Comsinlt with the departunent of health in matters of policy affincinis administration and enforcement of sections 3701.90 to $371) !$.! 1 , intusivi:, of the Revised Code, and in the development ol rengulatious;

(2) U!me quinterly each year and additionally at the call of the dirceltor
Section 3701.94 Handling sources of radiation.

All sources of radiation shall be shielded, transported, handled, used, and kept in such a manner as to prevent all persons from being exposed to improper radiation.

Section 3701.95 Prosecution for violations; injunctions.

(A) The attorney general or prosecuting attorney of each county to whom the director of health reports any violation of sections 3701.90 to 3701.98 , inclusive, of the Revised Code, shall cause appropriate proceedings to be instituted in the court of common pleas without delay and to be prosecuted in the manner required by law.

(B) In addition to the remedies provided and irrespective of whether or not there exists an adequate remedy at law, the director is hereby authorized to apply to the court of common pleas in the county wherein any of the provisions of sections 3701.90 to 3701.98 , inclusive, of the Revised Code are being violated, or violation appears imminent, for a temporary or permanent injunction restraining any person from such violation or threatened violation. In an action for injunction to enforce any final order of the director brought pursuant to this section, the finding by the director, after hearing, is prima facie evidence of the facts found therein.

Section 3701.96 Exception of radiation for medical purposes.

Sections 3701.90 to 3701.98 , inclusive, of the Revised Code shall not be construed to limit the kind and amount of radiation that may be intentionally applied to a person for diagnostic or therapeutic purposes by or under the direction of a physician or dentist.

Section 3701.97 Notice of violation; proceedings; declaration of emergency.

(A) Whenever it appears to the director of health, after inspection, that there has been a violation of sections 3701.90 to 3701.98 , inclusive, of the Revised Code, or any order of the director or any regulation of the public health council promulgated pursuant to such sections, the director shall give written notice to the alleged violator setting forth any thing or act done or omitted to be done or claimed to be in violation of such sections, order, or regulation. Said notice shall state that, unless the matters complained of are corrected within sixty days from the date of said notice, or unless the alleged violator requests a hearing before the director on said matters within thirty days of the date of suid notice, as specified in section 119.07 of the Revised Code, the director at the end of said 
sixly-diay perind maly make and issue such order as he deems alpropriatle. At the expiration of the period of sixty days from the latt of sabil motice, if the matters complained of have not been currectut, or if stlch alleged violator has not requested a hearing on siticl matler.s, the director shall proceed to make such determination atml urdere its is itplumpriate.

(B) All mistet:dings of the director or his agents under sections $3701.91)$ to 3701.98 , inclusive, of the Revised Code shall be subject t.) ind guverned by sections 119.01 to 119.13 , inclusive, of the Revisisel Code.

(C) Whrenever the director officially determines that an emergency exists mytaining immediate action to protect the public health or welfire, lwe may, without notice or hearing, issue an order reciting the existence of the emergency and requiring that such action be tak $1: 11$ it: is incessitly to met the emergency. Notwithstanding divisions (A) innd (1!) of this section, such order shall be effective immuedliatlely. Any person to whom such order is directed shall comply threrewith immediately, but on application to the director shall be alforled a hearing as soon as possible, and not later than twe'llly "litys allur such application. On the basis of such hearing, whe directur shiall continuc such order in effect, revoke it, or modify It.

Section 3701.98 P'rohilition.

No fursum shill violite or fail to perform any duty imposed by sections: 3711.910 (3) 3701.98 , inclusive, of the Revised Code, or violate any vit!il order of the director of health, or regulation of the public he:alth (o)uricil idlophed pursuant to such sections. Each day such

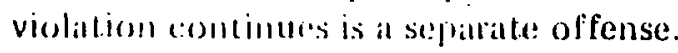

Section 3701.99 Penalties.

(A) II'Hu.w.r violitu:s suction 3701.18 or 3701.19 of the Revised Cuck: shall he lined not less than one hundred nor more than five humbled dolliass.

(B) Whreverer violiates scition 3701.25 of the Revised Code shall be fimel wos. morte thith one hundred dollars or imprisoned for not mure llawn niarty dilys, or both. No person shall be imprisoned Imoter. Hhli division low it first offense and the prosecution shall al. wily's lo ats les at lirit oflense unless the affidavit upon which the prositrulion is instituled contains the allegation that the offense

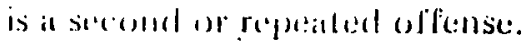

(C) Whoever willfully violates section 3701.46 to 3701.50 , inclusive, of the Revised Code shall, upon conviction in a summary proceeding in the county wherein such offense was committed, be fined not less than twenty nor more than one hundred dollars to be paid into the general fund of the county, and, upon failure to pay such fine and the cost of the prosecution, shall be imprisoned not less than ten nor more than thirty days.

(D) Whoever violates sections 3701.51 to 3701.55 , inclusive, of the Revised Code shall be fined not less than fifty nor more than one hundred dollars for a first offense; for each subsequent of fense such person shall be fined not less than one hundred nor more than three hundred dollars.

(E) Whoever violates section 3701.59 of the Revised Code shall be fined not more than five hundred dollars.

(F) Whoever violates section 3701.98 of the Revised Code shall be fined not more than five hundred dollars or imprisoned not more than one year, or both. 
APPENDIX C

SELECTED NEWSPAPER ARTICLES 


\section{Opinions vary on low-ievel radiation at Davis-Besse}

\section{By Jewer Laview}

About 10 days aso. a radiation tectuicting at the Dovir-Besse ovclear power plast near: 7 Clintoo -ralled into a bigteradiation area it the plant. In about 45 secoods. to was exposed to as much tom. zerous radiation as the federal covernineot said be should get in a year.

The expocure was trealed sen. -aily by the Nuclear Regulatory Commisaion. which sent is puclear imedical experts and then cited Ioledo Edison Co.. the plant iparator, for three violations.

Edison also treated the matter Jriovaly by notifying the media. soosth two days later. and by im. jodliately nying out data rogarding tobe minhap for tentine

i: And get, the man. whose anme was not relensed, returnod to wort the vent dyy.

Nomarous experts were anked aboat the danser of the exponure. Their responses abov the divtsion a scieatfic opinions on low-level redintios. desplts bearly 30 years and 81.8 billion in federal research.

"This exposure should not result ib any medically detectable effects Dow of during the lifetime of a person so exposed." said Dr. Rozer Linnemao. a consultant to Toledo Edison and a resesrcber at the University of Pennsylvania Medical School.

Dr. Thomas Winters, a researcher With the University of Massa. chuseter Medical School, challenge Linserma's asmurances.

"What it comes dowa to is that that mas was exponed to excewive rediatlon," be said. "There is oo way to knoge rtat rill mappen That man bad his gonads, testes. sperm and every organ in bis body exposed.

"That could potentially affect him gepetically or cause cancer. It is five for Linoeman to make a statemeat like that but there is no ( way for bim to say it deflaitely won't cause cancer."

Strangely, Linseman agrees.

"The true answer is we doa't koom." be admitled. "Te have bees unable io detect any effect in anj. mail and humas studiea Does that mean there are no effects? We don't know."

For Dr. Hymer L. Friedell. a mad Intimately lovolved with radiation all of his life, the confusion is understandable.

"We live in a sen of radintion." he saud. "We get about 100 millitrad (a) 1 nopts of a unit of atracorbed

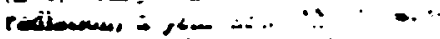
third come from coamic rays. another third comes from the Earts and mare from the redietion withe

you rucht norr."

He suid we receive mone ractiothoo from $X$ rayn from televtsion and from plane trips and eves cerhis medical toete But. Friedell sald. "How cas you tell the differexce betrieed 100 millirads and 101?"

Friedell was part of a nuclearmedical team which meat into Hiroabimn, three weets after the first atomic bomb was used in wartime there. He said mont of os,000 denths resulied from the fires and explacions from the bomb. but several thuteand sutsequeouly died from radiation expoanre.
Retired director of radlolocy at Cace Weaters Reserve Ualversity. Friedell said. "We know what radiation can do. It tears out the electron from the atom. The atom does't exia by ltself but in a chain of atoms. Uniess the bond goes bect. it dirturts the molecule."

Frtedell end. It affects moleculea in the body in raodom fachion. It might affect a molecula in the stio - ir allact a mavecula or is the thyroid or one which

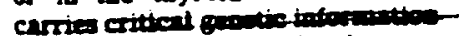
about how a child will develop.

$u$ the molecule were in the stin. the individual would aever twow it. Fundrede of thourapde of bitio molecules are loat every day and are oover mimed.

II however, it were DNA molecule - aes which conturis the

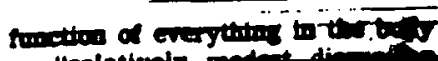
Fill create sorions eflects " Prwe in sild Tro elfects conld rum to

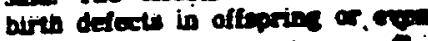
carear.

moen dangers are wellteows and are the barth of the feer of nuclear powes. whetber in ebetice sceratios plasts of 1 boenta. 


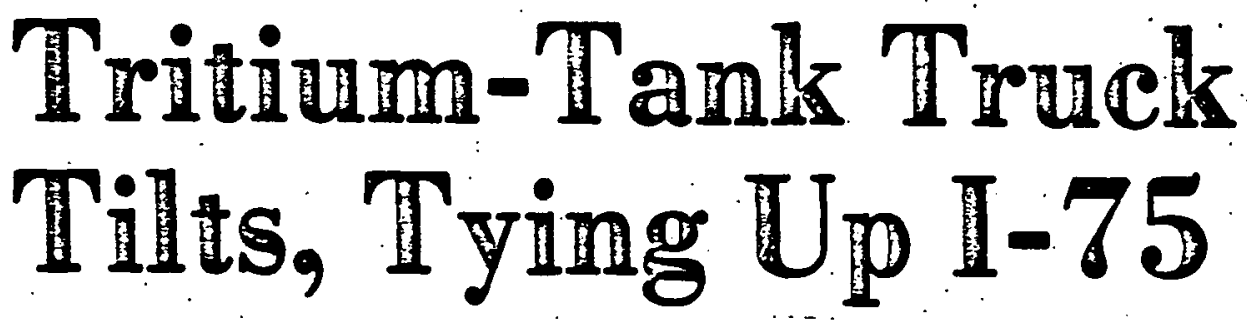

BY JOAN EOKBERG

and Swaver rith

A Ilacbod truck carrying 21 low-level radioactive tants upped on southbound $1-75$ in

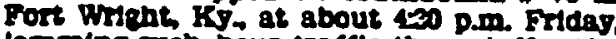
famming ruah-hour traffle through Norenem Kentreto to Exmard Charles Ditve in Clnelnning

- Otfletals said there was no radiation levtape and no lltollhood of radtation dan8er. There were no injurtes in connection With the acetdent.

Pollce rerouted southbound tratlle around the accldent at. Firth gtreet in CovInstoen, snd northbound traffic was stopped as Ineorrato 313 in Kentucts.

The hlghway and the Brent-8pence Bidge ware reoponed about $11 \mathrm{pm}$

Tre truch, orried by All-state Trucking Co. Fas tranporting emper contalners once thed to banl Extium and other gases at the

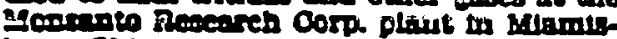
cury. Chla, sccording Howard Charbeneau. Hemenco public reln tions manarer.

Tattures 13 a lor-level radlonctive leotope of byerceen enat is used in nuclear treepons when dith compenseses and tho exde stons in itrolnner consbeneul sild

Twi toud wos bound for a 0 帛 Depart ment of Bners stte in Neven phere the enats ware to be boried.

- Izis Cyyl as Conington got so backed os Dith traific that thoy were afrald they covlda't gat sny emersency equipment throen on thotr ade 20 we anut down I-75 at

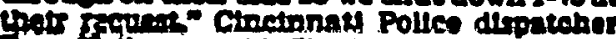
DW Elliow seld Cinetnanes pollce closed the Brent-spence bridge $48 \mathrm{pm}$

"inverthing is tacted up eione" a CorIn tou polles disonicher sula. Tratile on the

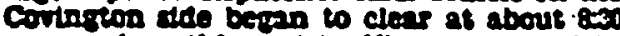
pm. and aorthbound tratte whs oponed in

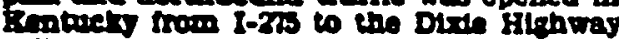
adt.

Jobn Glatelog, 4200 Indian RAPro Rd. Dortog, nat the drives of the truct if sald be pulied to the barm neas the Kgles Lane

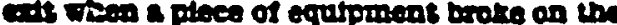
buct of ens truck He rotered furthe commank

Polles and the truck toped whan a rear pheol exing an the berm a Hiahlay pulled ores. Churbaneny said the tants had a level of ridioncestro the could onily detocted in a leborntary deurten.
"IN TBRMS of trieum in the tants, we are talking about tritum that is bound up in the metal of the tants. I do not belleve that somebody coming in with a detector could detect radtoactivity in there, It's so low," ho sald.

There is no danger. If the - tantes were oreached. If would be impossible to separate backoround radiation from the tanta," be sald.

- Bentucky authortices alerted ridiation control officlals with the Kentuctsy Consumer Healet Protectlon Division of the Department of Human Resources in Frankfort to monitor radloactive levels at the accident.

Tritum oxdde is not constdered a toxtc gas uniess it is in extremely large doses,". sald Don Hughes, manager of the departments at the scene.

"As far as radtologdeal hasard ts concerned. tritium is not particularly toxte" said Chuct Deberee, a Nuclear Rerulatory Commisxinn dut officer trom Chioago, "I would gues that there is a relatively small danger level."

In terms of safety, we would be more concerned if the tructs were carrylng chiorine, for intrance." Charbenewu sald.

"IN ANY sort of accident situacton, people tend to overreact, and I thin't that's ver reasonable about what at the time is unnown."

Ho sild that recuum was applied to the tan's at the Monsanto plant before they left the plant on Thureday, so that if an opening oceurred, there would be no leat.

Hovever, the compang may be in vtoler. tion of 8 Covington ordinance regardins transportatlon of hazardous material through the elty vithout prtor noturleation. The lov went into effect May, 1980 . The tav cartea a 9800 fine, said Joseph T. Condih. coringron sollestor.

Covtntan Major Bernard Moorman sid barge compantes and rallroads were notifled of the law, but truck companies were not notsited directly. Both Moorman and Condis quoted the sdict 4 morance of the hat is no ereus for brev ring it."

The lew ruquise anyoody tating has. ardoun meterial through the elty to flrst noury the tire department The tire depart ment we not notifted of the All-bintes shipment.

"I know the inconventence to a shipper. but I nnow the potential problem for a community," Moorman sald. 
Aprí 14, 1980.

(continued)

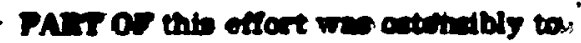

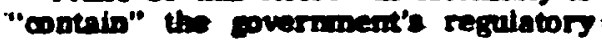
ox: But tho promottonal effort clearty had the object of making nuclear power economically competitsve with other lorms of eneroy.
\end{abstract}

mough this attutudelexted 30 geari, to

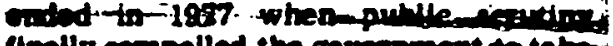
fin lly compolled the goverument to th

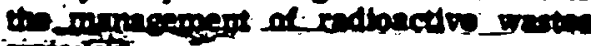
inters

Now it bo propod minth and malth tailings be managed as transuranic and high level wastes! The probable cost: in the billions of dollars.

\section{Low Level Wastes Given Shallow Burial}

- Low Level Wastes (LLW): These incompass a large variety of substances. which remain radioactive for up to: averal-hundred-years. Faium cycle, in both military and $\because$ mmercial operations. Low level wastes zyolve as wet solids and compact and noncompact dry solids.

Historically, they have-been managed by what is called "shallow land burial," itat is, in trenches 20 to 30 feet deep, with a soil overburden of 5 feet. This 5 -foot backfill shields radiation from the atmosphere and is also intended to prevert exocion from exposing the waste to the surtace.

$-7$

STrus. ARB selected and trenche designed to minimize migration of waste fluids underground and contamination of the water table. There are 14 Department of Energy ILW burial sites (and two closed sites), used almost exclusively for millitary nuclear wastes, and six commoncinl LLW sites.

Three-of the cominercial sites-hwer bean closed for sofety rentions. The Wext Valley; N.Y. ste war abandoned by then commorereint company that operated the leaving its management to the state and. locking that, to the federat govermmem.

The initial estimated cost is $\$ 500$ : malion the state of New Yort gaye th; crinot affond that and is trying to. transfer ownership to the U.S. Departmont of Energy (DOD).

On of the problems with theis two commerchl altes and with DOE millting ULW sites at Savannah RIver, S.C., and Hinford, Wash., ts that some higher level

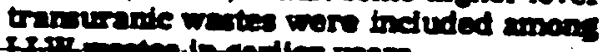

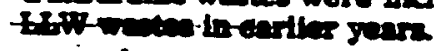

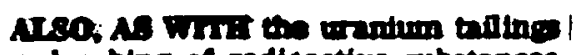
dicen leaching of redianctive substances Into the water tabro. at LWW sthes- he bowint tha "shallow land burial" concept veder quattoning prtmartly by a spedil

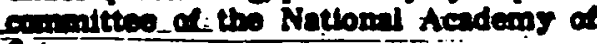
cionces.

hrolved an the regulntory procen tocele. Iong-torm, (mundrods of yonrs)

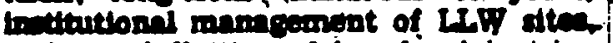
en a redefinttion of low level conitin: rantion standerds.

Approximately. 3 million cubie feat of LiW aro gonorated each year. About 20 million cubterter are stored atcimmar tel ifter and 50 million cuble leat it Lififgerse Bigh Level Wastes Can Be Used In Weapons

- Hith Level Wastes (HILW): Theas wares derive from two main sources: Intact reactor fuel assemblies which remain after serving their useful life (spont fuel) and those wastes from the "reprocesing" of spent reactor fuel that cantain both the radianctive byproduct of the firston process and, most of the "bavyet-sodianctime alemeints not seperated out durting reprocesine

ra- Todate reprocesidos of spent reactor

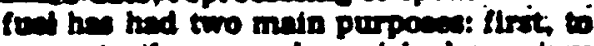

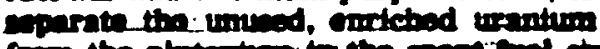

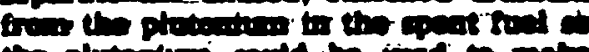

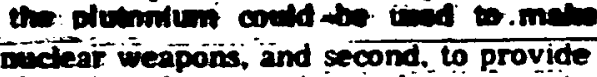

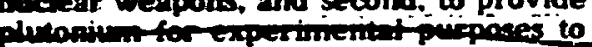
develop the liquid metal-cooled. Fasttirocter reactor-for-tho-production of. etectric power.

From THis, one can see that spent fue from commercial nuclear power plants is not necessarily a radioactive proste." But it has been classified assuch for the time being because President Carter declared an indefinite morato. rium on spent fuel reprocessing in 1877.

The purpose of the prohibition was to: give the world's nations using and/or planning to use nuclear power reactor time to determine if there was an effective alternate fuel-making technoloow which would prevent access to pluton ium and thereby prevent its diversion to reapors making.

Aside from this non-proliferation it sus, spent fuel is the prospective main source of nuclear fuel for decades to com for a second-generation breeder power renctor (which can "breed" more plutanjum fuel than it wesh).

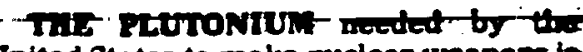
United States to make muclear weapam to

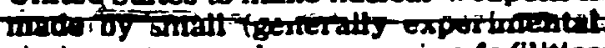
stow reactors and reprocessing faclltie DOB owm to sarve the milltary:

What makes opent fual for the mom - high level radioactive waste- is: tho plotonium in its pellet - the unuedi" inctched urantion _. plus tho-otber redionctive byproducts and heavy lop.

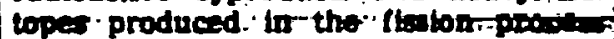
while the fuel in in the reactor.

Spent fuel is stored above ground at renctor attes in pools of water. The water.

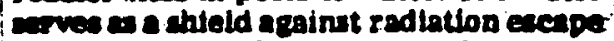
and drotpates the immense hat pio fued by the-decaying of the radlocettre muerthis in the furi.

The fual contatms virtually ill of this?

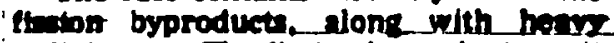
radblootpes. The theion byproducts emit bato-rumma radiation. The heavy: wo. topes emit elphe radintioa.

MOST OF THE beta-gamma byproducts emit great heat. but lose practically all of their radioactivity within 1,000 years. The few which yueld little or no heat, such as todine-129, technetium-89. zirconium-83, and cesium-135, remain radioactive from 2 million to 17 million years.

The alpha-emitting . heayy tsotopes (high atomic number), such as plutonium. 238 (pluxionlum-239 is the weapons mnterb), neptunium-297, and Amertcum-24L, Epwin "daughter" isotopes as thoy docy.

Thew daugheors aro also alphe emto win, and they decay they produce aditional daughtern; which llkew teo cont apheradiation:

Depending on the type of orighal havy leotope, these daughter chairs of alphe radiation 80 on for: thousands of: genrs to 2 million years.

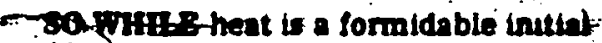
poblem in storing apout fuel in modtr.

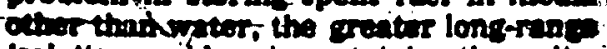

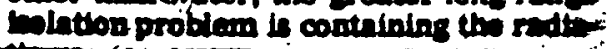
the

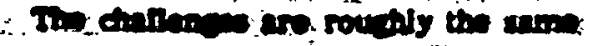


Apris. I4. 1980

(Continued)

when it comes to "ultimate" or-"terminal" isnlation; or final sturage, of the other main type of high level radiuactive waste - the residue of militiry reprocessing.

The residue remaining after the enriched uranium and plutonium-239 are separated from spent fuel is produced in liquid form. and also contains fission byproducts and heavy radioisotupes.

While this residue does not create the amount of heat unreprocessed fwel creates, It contains the short- amd longlived beta-gamma emilters, and the long. lived alpha emitters. Yet, heat generation remains a significant prohlem.

HEAVY SHIELDINI; is required io contain the radiation of military HLW:

At least 77 milition gallons of this HEW are stored in tanks at Savannah Kiver. S.C., Hanford, Wash., and- ldaho Palle. Idaho. Leaks from holding tanks have occurred at two of these sites.

At Hanford, 430600 gillons. have contaminated the soil and: at Savannah River, a. 100-gallon leak is recorded:

The contaminant at Savannah Ruver may be recoverable; but the onntamint: ed area at Hanford may; for all practical purposes, become the nation's first "perpetual repository" of nuclear wasto to be institutionally managed for as lone as present mankind can-foreseo

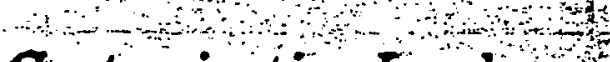

\section{Contamination Leads}

\section{To Transuranic Wastes}

- Tranurarie Wastes (Trus This avi generally colids containing radiot topes: of highor atomic number the

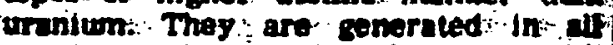
uranium cycle operatiom, beginning with untumi entchmont to produce reactio fod: -1 - They conot chtenty of equipinone dint structures contaminated by oxponien to radiation: and aro produced in lare volume, mainjy in millenry reprocosito of spent fuel. intelding: nor do they onarvita muen heat. However. inay comtain; longlient

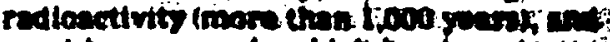

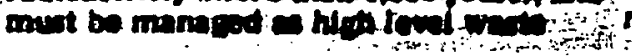

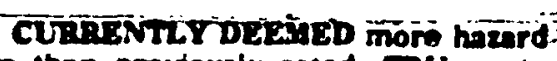
an thon previously rated, IRU wastes un undergoing redefinition. -

-.. Gaseous Effuents: These are ro dlasctive gases released into the blom phere (air and water) in small, contralled amounts lexcept for radon from tailing pilest from vartous installatlori in the

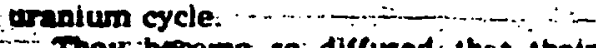
They beinome so diffused that ibotr radlation, often short.fived, is generally. reourded a a contamination tolerable to Here without restdual pazard.. -

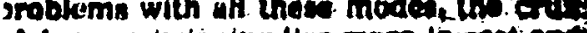

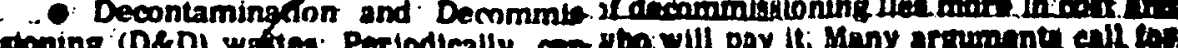

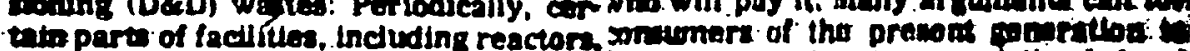

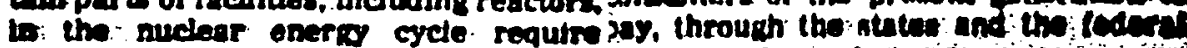
decontamination to permit thetr contib prommatis ued operation.

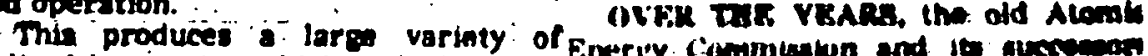
radiasctive iwastes which muixt he man. have chosnn not to nppmach docommin

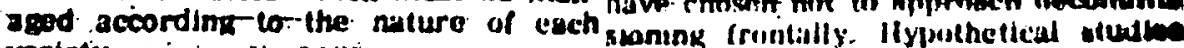
varioty.

however, have husen. comminatonad 4

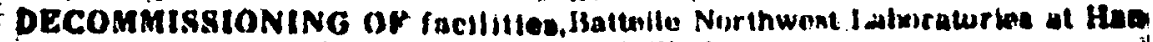
bovever, to anther; and lortuow, stay, fnrd. Waxh

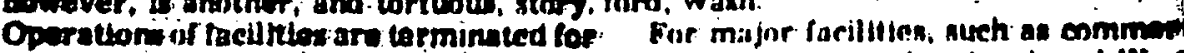

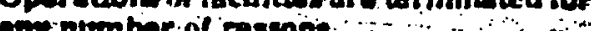

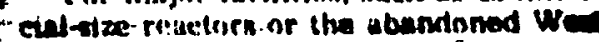

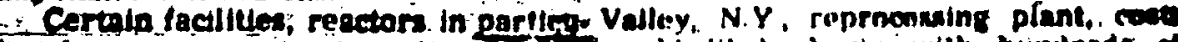
tr. become so conteminated eventurtif would likply beis with hundreds

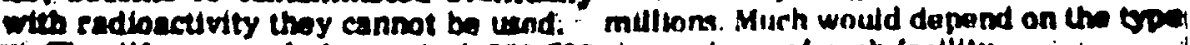

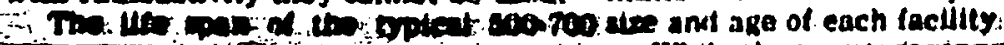

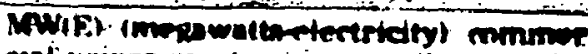
coli pawer reactor is gonorily regard av boing about toryare befare enmtamina tion nvertakity it.

Suke livis. rive nuciear power rese co cars four demonstrition reacurs and sir test reactors have beell dectimmisatoned Anather 50 reselurch-type roactors haw bean decumimissionud, miaslly by. diaman ling:

ar. stomge: or mothballing, and entomb meat.

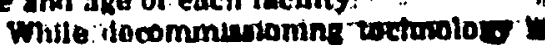
conarally avallable, hypothetical modely b. dotormus probable: coula: numin genorally. lacking. All thos contu the remain to he ligured in. partlcularly for commercial nucloar powor:

In tha neuntuma, thi lactar quection aim romains as to how this country ase.

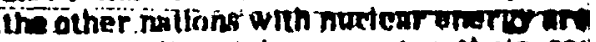
coing to ultumately. aquontor thate $r$

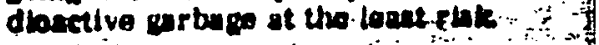

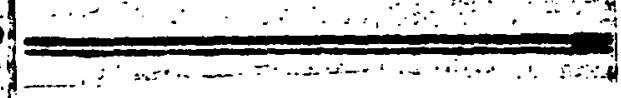

A ComniNationN, aule sto pertud-of years: to permit criviling and deciy followed by dismantling in boas propusied.

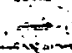

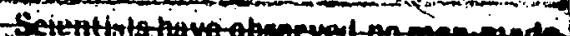
trurtura cuuld lant long enoupti to anfely: entamb or protectively stom a full.life

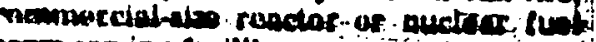
reproming fadtily. 
UC problems. grow more acute Fifidelays

THB BODDEN bar on atomic waste in Nevede, Wasinington and Soüa-Carollns threatem the Universitg of Clncinnath. Concta Bosplen and other medical centars-acous Amertes with the cutoll of matre mullions of dollars worth of reactei.

L

The atomic-junt crisis at UC is indeed sertous For what was, by compartcon, a modest amount of nuclear waste there in the early 1970 sas mushroomed along with the nation's crash drive for crncer answers.

Thus only 30-50 55-gallon drums of 10v-level adiation waste in glass vials were genersted at UC stx or elght years apo. But $\&$ wopptog 330 - budgeted for sum in transport and dispoenl costs are expected in 1900. Most - majbe 75\% - is extremely low-level, according to Kenneth M. Fritz, radiation safety off1cer for the UC College of Medlclne. It's so low, in lact, the Nuclear Regulatory Commission (NRC) told him it could be hindled much llte any other hassious chemical raste. But Mr. Frttz can't find a dump for it Operators of two meste stes told him the Ohio Environmental Protectlon Agency (OEPA) won't let them accept ith

Research-generated waste - surph in tireproof areas (In short supply) unli. dispatch - is mainly what Mr. Frits calls Hiquid setntillation cocktell flute" The nuid is inflammabie, and its rumer innaled, could be dangerous, he satd. The

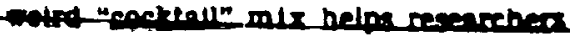
sack radoacture matertak. The other lind of radloactive medical maste is of the dlagnostle short "half-Lfe" vilety poaing no problem. Slx hours behind a lead shietd and there's -Jung left of It," a UC medlcal expert says.

NRC has asted every state governor to condider nuclear weste - including that Irom reactors - a tritional problem. And It's taken a blood oath. 50 wo speat. 10 up. grade tederal survellance to ensure agalnst transport-and-packagtng abives of the rted that brought the three-state halt A sti commlesion recommended w Prestden tirter the regtona han. dilng of lowal plan.-Mean it ? 3 , ORPA sass it wont licease landfllis to scept such vartes unlll the U.S. Envtronicontel Protcetloa Agency comes out with its guldellnes ortiginally secheduted by the end of the jear but predlctably, not expected now before next Apru.

So goes the buresucratue merty-goround. But before desperatson sets in at UC and elsewhere. the U. S. Deparment. of Bnergy (DOE) mag pulf a rabblt out of the hat: A contingeney plan. we'te wid. calls for emergency disposal of stomlc wastes in DOE's abundant tacullties in such places as its Sandia laboratory in New Mexico and at Oat Rldigh Tonn. But regional action under national plans with governors and all affected agencles involved - may indeed be the longranke snswer. 